\title{
THE ECONOMICS OF DISASTER RISK AND RECOVERY: \\ THREE ESSAYS ON SRI LANKA
}

\author{
By \\ JAYASUNDARA MUDALIGE DIANA DARSHANI JAYASUNDARA \\ DE ALWIS
}

A thesis

Submitted to the Victoria University

of Wellington in fulfilment of the

requirements for the degree of Doctor

of Philosophy

Victoria University of Wellington 



\section{Declaration}

I declare that this thesis, which I submit to the Victoria University of Wellington for examination in consideration of the award of a higher degree, the Doctor of Philosophy is my own personal effort.

I have not already obtained a degree or diploma in the Victoria University of Wellington or elsewhere based on this work.

Furthermore, I took reasonable care to ensure that the work is original, and, to the best of my knowledge, does not breach copyright law, and has not been taken from other sources except where such work has been cited and acknowledged within the text.

Jayasundara Mudalige Diana D. J. De Alwis 


\section{Table of Contents}

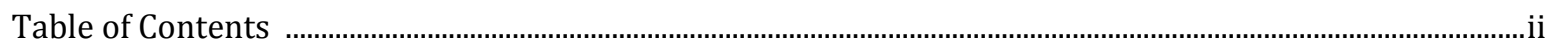

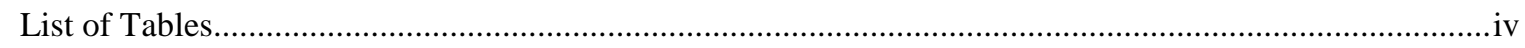

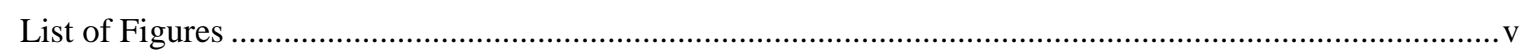

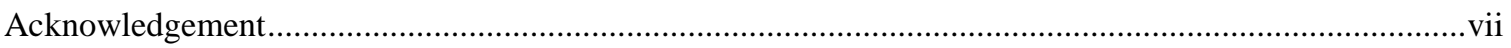

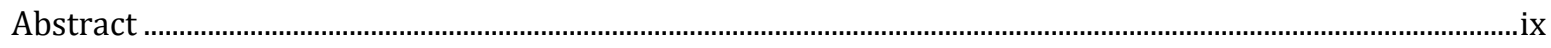

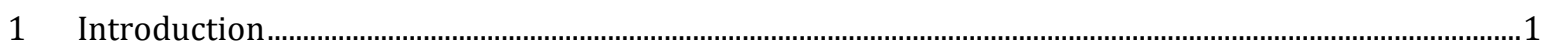

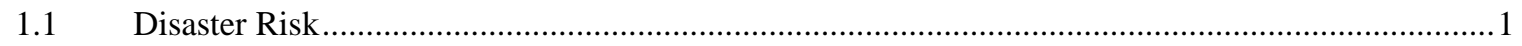

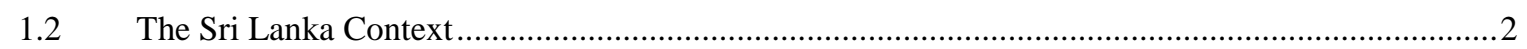

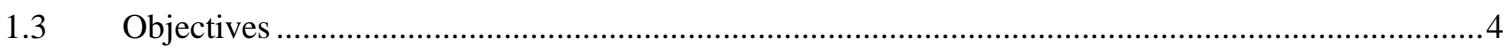

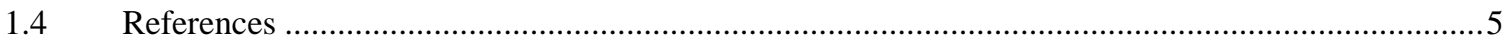

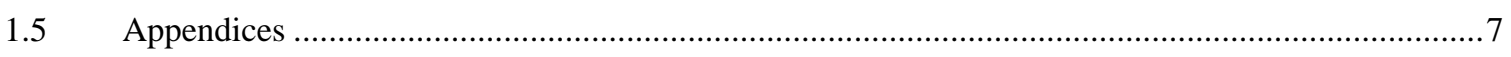

2 The Health Care Cost of Being Under the Weather: Droughts, Floods, and Costs in Sri Lanka ............. 9

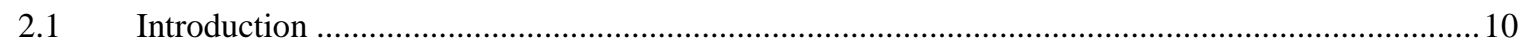

2.2 Related Literature: The Health Impact of Disasters.......................................................... 11

2.3 Background on Natural Hazards and Health in Sri Lanka .................................................. 14

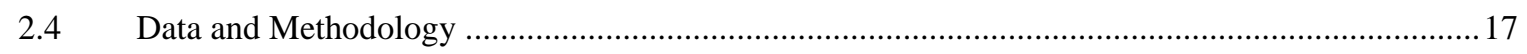

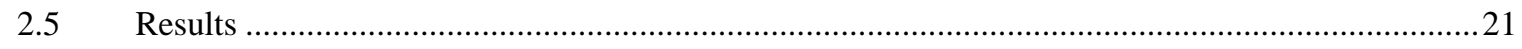

2.5.1 Health impacts of extreme weather: Inpatient care .............................................................2 21

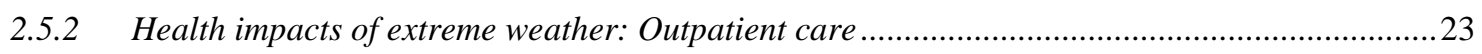

2.5.3 Interactions of the hazard variables with hygiene controls ..................................................24

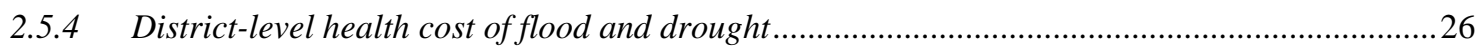

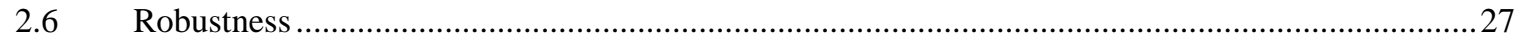

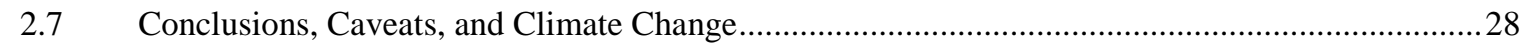

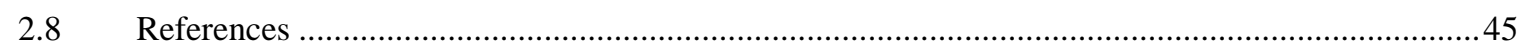

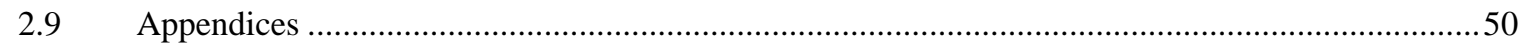

3 Sri Lankan Households a Decade after the Indian Ocean Tsunami...................................................... 77

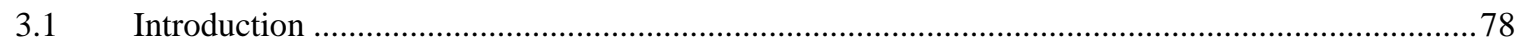

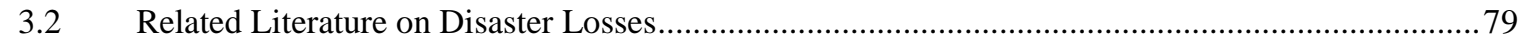

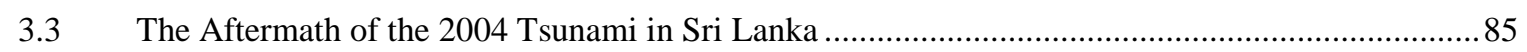




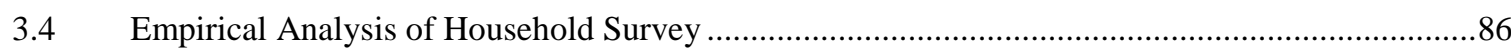

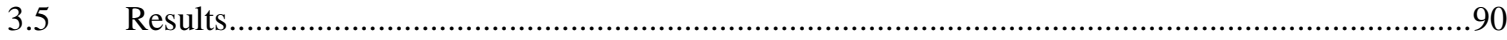

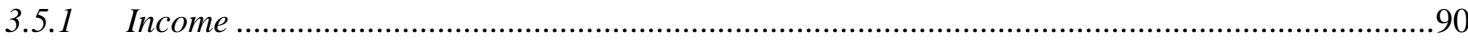

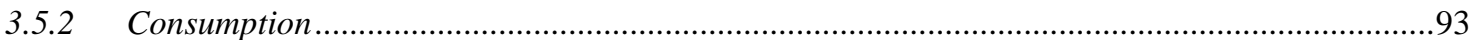

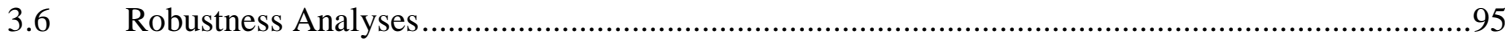

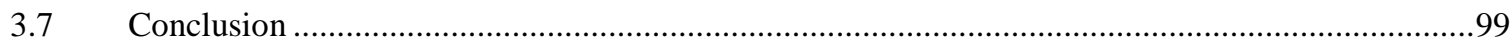

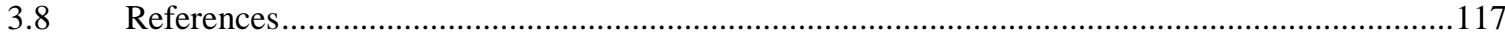

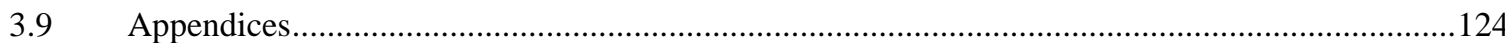

4 Distributional impacts of disaster recovery: Sri Lankan Households a decade after the 2004 Indian

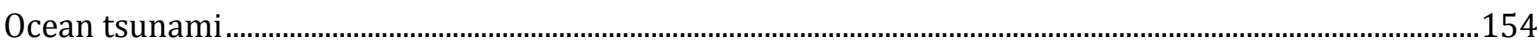

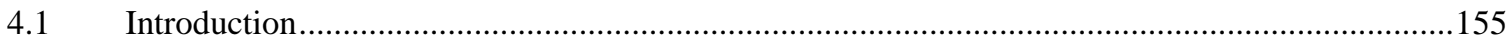

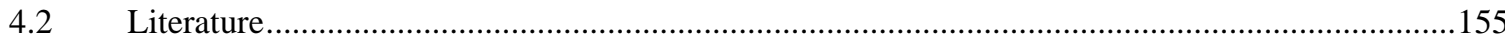

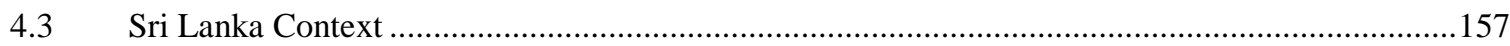

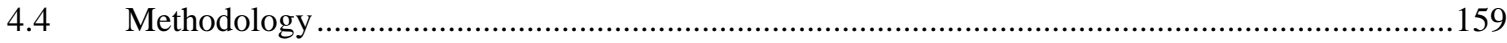

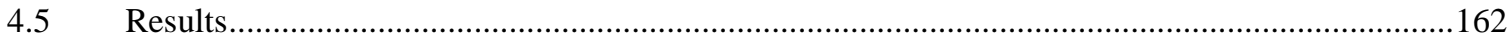

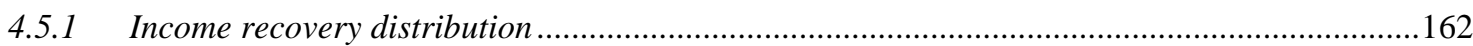

4.5.2 Consumption recovery distribution …......................................................................... 164

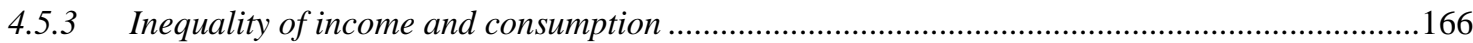

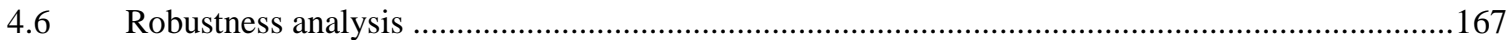

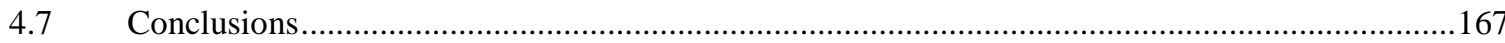

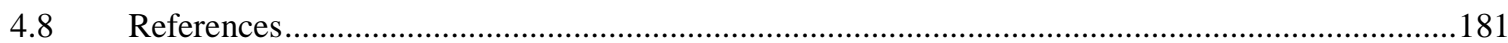

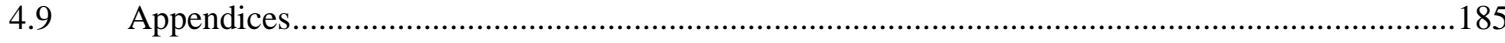

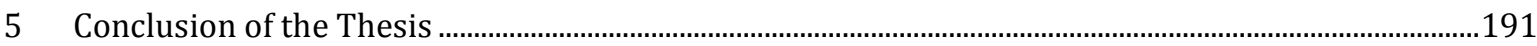

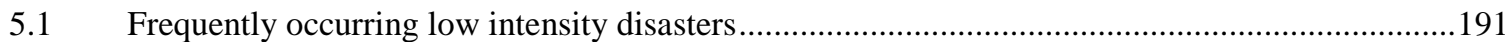

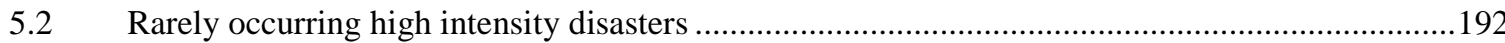




\section{List of Tables}

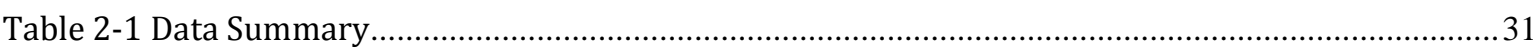

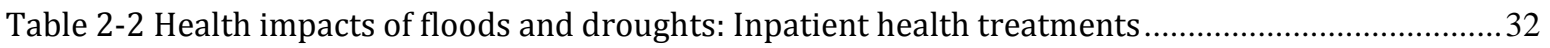

Table 2-3 : Health impacts of flood and drought: inpatient health treatment for different groups ..............33

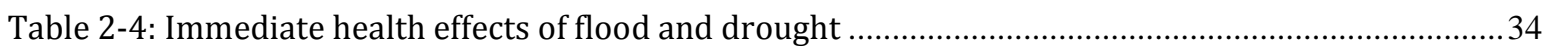

Table 2-5 Private healthcare costs (per month, for inpatient and outpatient services) ........................35

Table 2-6 District level population vulnerability to flood and drought related health risk ....................36

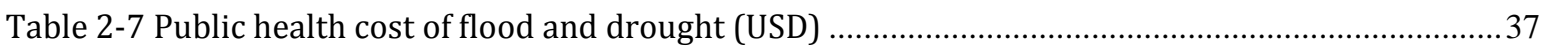

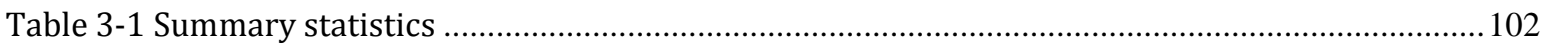

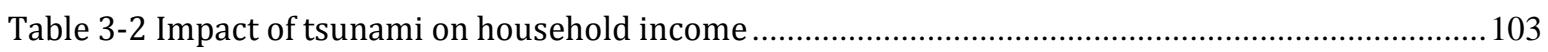

Table 3-3 Impact of tsunami on household income by source of income ....................................... 104

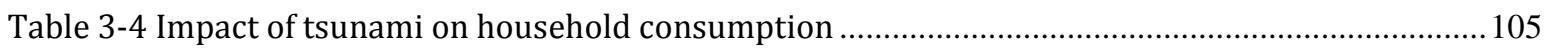

Table 3-5 Impact of tsunami on household consumption by type of consumption ............................ 106

Table 3-6 Impact of tsunami on household consumption by type of non-food consumption ................ 107

Table 3-7 Impact on consumption and income using log of income and consumption (log normal) .....108

Table 3-8 Impact on income: using dummy treatment variable considering five intensity indicators .. 109

Table 3-9 Impact on income: using proportion of population in affected administrative districts as the treatment variable and to identify treatment intensity.

Table 3-10 Impact on consumption: using dummy treatment variable considering five intensity indicators

Table 3-11 Impact on consumption: using proportion of population in affected administrative districts as the treatment variable and to identify treatment intensity.

Table 4-1 Summary statistics for quantiles

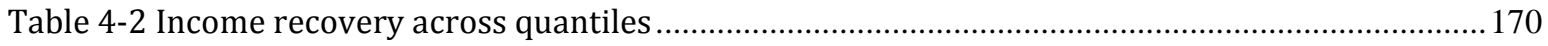

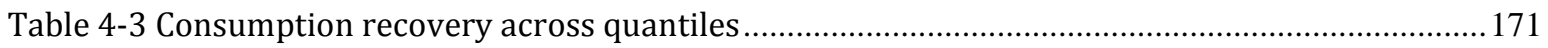

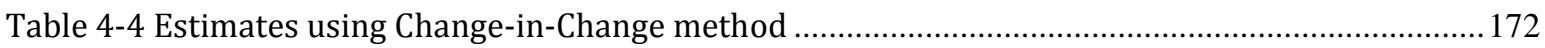

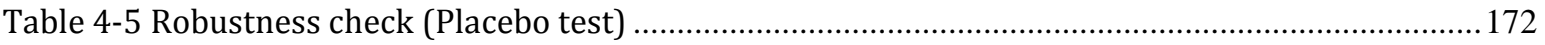




\section{List of Figures}

Figure 2-1 Interaction effect of flood and drought on seeking inpatient health care ..................................38

Figure 3-1 Household income across treatment and control groups ....................................................113

Figure 3-2 Household income across districts .....................................................................................113

Figure 3-3 Normalized household income of treatment and control group ............................................114

Figure 3-4 Impact on household income across affected districts in the post tsunami ..........................114

Figure 3-5 Household consumption variation across treatment and control groups ..............................114

Figure 3-6 Household income consumption variation across treatment and control districts...............115

Figure 3-7 Normalized household consumption of treatment and control groups ..................................115

Figure 3-8 Impact on household consumption across districts in the post tsunami .................................116

Figure 4-1 Income (absolute) recovery ........................................................................................172

Figure 4-2 Income recovery as a Percentage of average income ……………………............................173

Figure 4-3 Income recovery (absolute) in CIC method ........................................................................173

Figure 4-4 Income recovery as a percentage of average income in CIC method ......................................173

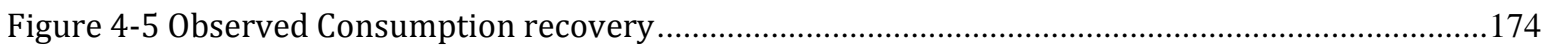

Figure 4-6 Consumption recovery as a percentage of average consumption ...........................................174

Figure 4-7 Consumption recovery in CIC method (absolute) ……………………..................................175

Figure 4-8 Consumption recovery as a percentage of average consumption in CIC method ..................175

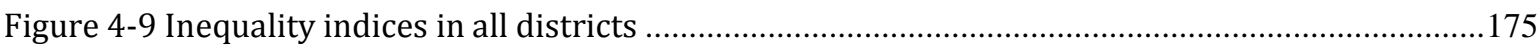

Figure 4-10 Inequality indices in affected and not affected districts....................................................176

Figure 4-11Nomalized income of $2^{\text {nd }}$ quantile ...................................................................................176

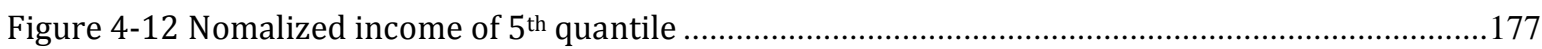

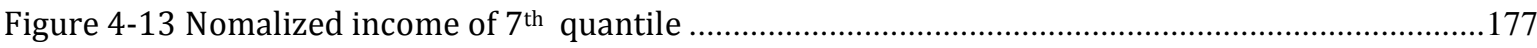

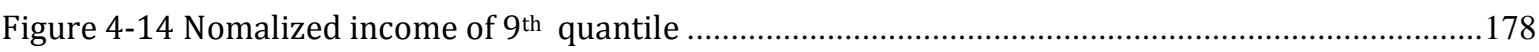

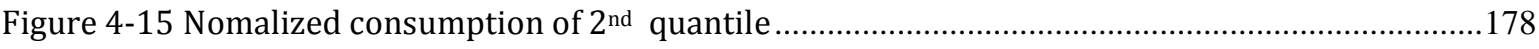

Figure 4-16 Nomalized consumption of $5^{\text {th }}$ quantile .......................................................................179

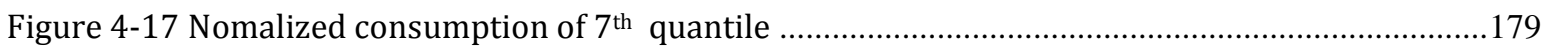

Figure 4-18 Nomalized consumption of 9th quantile ...........................................................................180 
Most respectfully dedicated to my beloved parents and teachers 


\section{Acknowledgement}

I wish to thank the many people who so generously contributed to the work presented in this thesis.

Foremost, I extend my sincere gratitude and profound thanks to my supervisor, Professor Ilan Noy. My PhD has been an amazing experience and I thank Ilan wholeheartedly, not only for his tremendous academic support and guidance, but also for his extraordinary human qualities. I have been extremely lucky to have a supervisor who cared so much about my work, and who responded to my questions and queries so promptly.

I am also hugely appreciative to Dr. Harold Cuffe, my secondary supervisor for sharing his Econometrics expertise so willingly, which were determinants for the accomplishment of the work presented in this thesis.

I also wish to thank the members of my dissertation committee: Professor Sisira Jayasuriya, Dr. Andrea Menclova, Dr. Luke Chu and Dr Marco Sonzogni, for generously offering their time, support, guidance and good will throughout the preparation and review of this document.

To the Victoria University of Wellington (VUW), I would like to express my sincere gratitude for providing excellent material, logistics and human conditions from the beginning to the end of my $\mathrm{PhD}$. My sincere thanks goes to the academic and administrative staff of the School of Economics and Finance (SEF) and the staff of the Faculty of Graduate Research (FGR) for helping me in many ways.

I gratefully acknowledge the financial support received towards my PhD. I am sincerely grateful to the Chair in the Economics of Disasters, VUW for the fully funded scholarship which had made this study possible. I also thank Professor Ilan Noy and Professor Jack Robles, SEF for recommending additional financial support to complete my thesis and the VUW for offering the PhD thesis submission scholarship during the last three months of my research.

A bunch of thanks goes to the Director General and the staff of the Department of Census and Statistics, Sri Lanka for sharing their household survey data for this study. I also 
benefitted from the comments and suggestions from the participants at various conferences that I presented my work. My thanks likewise goes to those conference organizers for accepting my papers and the participants for their valuable comments.

The members of the Ilan's economics of disaster group have contributed immensely to my personal and professional time at Victoria. I am especially grateful for my disaster economics group mates Rio, Azreen, Miles, Tausi, Melissa, Aditya, Cuong, Farnaz, Olivia, Hannah, Jacob, Belinda, other fellow PhD candidates of the SEF and my other friends elsewhere, for their thoughts, well-wishes, advice, and being there whenever I needed a friend.

I will always be in debt to my closer friends, Rashika and Raj for immense support they have extended to me over all these years. I can never thank them enough for being so gracious to open their beautiful home to me to stay and making me feel so much at home there and, unconditional friendship, encouragements and support they gave me at the most difficult times of my PhD journey. I have very fond memories of my time there with Rashika, Raj and son Rahul.

Last, but not the least, I would like to thank my family, my parents for their unconditional support both spiritually and financially throughout of my life. I love them so much, and I would not have made it this far without them. My sister and my brotherin-law have given me unequivocal support personally, and taking care of my parents in my absence, for which my mere expression of thanks likewise does not suffice. My nieces Komuthu, Nesadi and Minadi have always been a source of joy for me; I fondly acknowledge their love and affection to me. 


\begin{abstract}
Dramatic increase of economic losses from Natural disasters derail economic and human development in many places. This dissertation sheds light on natural disaster risk and short-term and long-term household wellbeing after disasters. It is composed of three empirical studies of Sri Lanka.

The first study examines the impacts of frequently occurring extreme weather events on individual health and health care cost using national household data. The analysis shows that local floods and droughts impose a significant risk to health when individuals are exposed directly and their communities indirectly to these hazards. These risks are associated with the land-use in the affected regions and the status of access to sanitation and hygiene. Health risks due to flood and drought cause a considerable economic burden on the private and public health care sectors. Finally, we learn that recurring extreme weather events may potentially be sources of significant health risk and economic cost to a rapidly growing developing country that call for alternative policies focusing on the socio-economic environment, and land use to manage these health risks.
\end{abstract}

The second study estimates a difference- in- difference (DID) model to examine the 2004 Indian Ocean tsunami's long-term impacts on household wellbeing in Sri Lanka. The study finds a strong association between area-wide tsunami disaster shock and increases in household income and consumption in the long-term. The increase in consumption is much smaller than the observed increase in income; the study reveals an increase in food consumption and only a marginal increase in non-food consumption.

The third study analyses the 2004 tsunami recovery's impact on income distribution across households in the long-term in Sri Lanka using quantile difference-in-difference methods and inequality measures. Recovery of household income is observed across the entire distribution of affected households. The income recovery is skewed to lowincome households; the affected regions appear more income-equal ex-post compared to the unaffected regions. A similar pattern appears for consumption. Finally, the findings in the second and third studies show a potential for a long-lasting and successful recovery from a catastrophic disaster. 



\section{Chapter One}

\section{Introduction}

\subsection{Disaster Risk}

"The revolutionary idea that defines the boundary between modern times and the past is the mastery of risk: the notion that the future is more than a whim of the gods and that men and women are not passive before nature"

"By showing the world how to understand risk, measure it, and weigh its consequences, they converted risk taking into one of the prime catalysts that drives modern western society" (Peter L. Bernstein, 1996, p.1)

This dissertation quantifies the risk of selected natural disasters to Sri Lankan households in three empirical studies. The three studies adopt the widely agreed risk formula [Risk $=f$ (Hazard/shock, Exposure, vulnerability)] of the development (The World Bank, 2014), climate change (Inter governmental Panel on Climate Change [IPCC], 2012) and disaster risk (The United Nations Office for Disaster Risk Reduction [UNISDR], 2015) communities for conceptualization of disaster risk. 
The analysis views the natural disaster risk as the expected loss of wellbeing that depends on the interaction between hazard, exposure and vulnerability: the hazard is characterised by its size, location, severity and frequency, exposure of people and their assets that is determined by their location, and vulnerability that occurs when people and assets are susceptible to losses from these negative shocks because of insufficient capacity to cope and adopt.

\subsection{The Sri Lanka Context}

Sri Lanka is a tropical island situated in the Indian Ocean between latitudes $6-10^{\circ}$ north and longitudes $80-82^{\circ}$ east with a land area of $65,610 \mathrm{~km} 2$, and an exclusive economic zone over $517,000 \mathrm{sq} \mathrm{km}$ of the ocean. The country has an irregular, dissected topography comprising a broad coastal plain and a central mountainous area rising to elevations of $2,500 \mathrm{~m}$. The topography and differences in regional climate are the underlying causes of the different climates across the island.

Rainfall has multiple origins with mean annual rainfall that varies from under $900 \mathrm{~mm}$ in the driest to over $5000 \mathrm{~mm}$ in the wettest parts of the island. The mean annual temperature varies between $26.5^{\circ} \mathrm{C}$ to $28.5^{\circ} \mathrm{C}$. In the highlands, the temperature falls quickly as the altitude increases to $15.9^{\circ} \mathrm{C}$ (Department of Meteorology, 2015). The island is divided into three climatic zones, based on the annual rainfall: The Dry Zone, Wet Zone, and Intermediate Zone and; 46 agro-ecological regions that take into account soil, annual rainfall and its seasonal distribution, and altitude. Currently, more than 2,000,000 ha are under some form of cultivation in Sri Lanka (Ministry of Environment, 2010).

Sri Lanka is a densely populated country with a population of 21.2 million growing at $1.1 \%$ and accommodating 338 persons per sq $\mathrm{km}$ (World Bank, 2016). The population is 74.9\% Sinhalese, 11.2\% Sri Lankan Tamil, 4.1\% Indian Tamil, 9.3\% Sri Lankan Moor and 0.5\% from other ethnic groups; $20.5 \%, 26.3 \%$ and $45 \%$ work in the agriculture, industry and service sector respectively (Department of Census and Statistics, 2012). For administrative convenience, Sri Lanka is divided into 9 Provinces, and these are subdivided into 25 Districts. Each District is divided into Divisional Secretariats (DS), depending on the population size of 
the area. Each DS Division consists of several Grama Niladhari (GN) Divisions, the lowest administrative unit. Currently there are 324 DS Divisions and 14,009 GN Divisions in the country (Department of Census and Statistics, 2015).

The country follows a broadly open market-friendly economic policy from 1977, though the Government is the largest provider of services such as free education and health care. Sri Lanka is a lower middle-income country with a total GDP (real) 79.7 Billion US\$ (World Bank, 2016); $56.5 \% 26.8 \%$ and $7.1 \%$ are contributed by services sector, industry and agriculture sector respectively (Central Bank, 2016). Real GDP growth in 2016 was 4.7\% and per capita GDP was 13,800 US\$ (PPP) (IMF, 2016). Sri Lanka has a literacy rate of 95.6\%, Life expectancy at birth of 75, 0.76 for its Human Development Index and a Gini coefficient of 0.39. Still, $4.1 \%$ of the population and 3.1\% of total households live in poverty (Department of Census and Statistics, 2016). It also has a high burden of government debt - $77.6 \%$ of GDP (IMF, 2017).

Sri Lanka experienced a series of socio-political disturbances over the past several decades. From the early 1980s, Sri Lanka was caught in an internal conflict that escalated into an armed uprising by the Liberation Tigers of Tamil Eelam (LTTE). Seven districts out of 24 were heavily affected by the conflict. In 2009, defence expenditure was 3 percent of GDP during the most intense fighting (Sri Lanka Human Development Report, 2012). The armed conflict ended in 2010 when the army overtook the last stronghold of the LTTE.

Sri Lanka experiences many kinds of natural and human induced disasters (Appendix Table 1-1). Natural disasters account for more than eight times the number of causalities due to other human-induced disasters during the past four decades. The Indian Ocean tsunami in 2004 was the most catastrophic natural disaster event in modern times. It caused more than twice as many causalities as those caused by all other disasters combined. In 2004, infrastructure was heavily damaged, more than one million people were affected, and the estimated economic loss was 5\% of the country's GDP (Department of Census and Statistics, 2005).

Floods, rain, droughts, and landslides are the most frequently occurring natural disasters. Floods and droughts are experienced almost annually; the former cause deaths, property and 
crop damage, and the latter mostly affect agriculture. As can be seen in Appendix Figure 1-1, in the past few decades, the country experienced an increase in economic growth, population density, and an upsurge of disaster affected population.

The government of Sri Lanka has progressed considerably towards establishing a national policy and legislation for disaster management: drafting national disaster management plan, and a national policy for climate change, with broad objectives of preparing for and responding to disasters and climate change. The impacts of disasters, however, have not been systematically documented, and the government has yet to come up with mechanisms for accessing and ensuring effective use of resources for disaster preparedness, prevention, and response. In the pages that follow in this dissertation, we aim to inform disaster risk management policy and action in Sri Lanka.

\subsection{Objectives}

This thesis is composed of three complementary empirical studies in the main chapters 2,3 and 4. These three empirical studies from Sri Lanka explore the disaster risk and recovery at the household level. Three information gaps in the disaster risk literature motivated this work.

First, the impacts of floods and droughts are manifold; their risk on human health is apparent, but there has been little quantitative evidence to document these impacts. With this in mind, the first empirical study "The health care cost of being under the weather: floods, droughts and costs in Sri Lanka" examines health vulnerability to floods and droughts in Sri Lanka. The study answers three research questions: (1) what are the individual health risks attributable to flood and droughts? (2) What health spill-overs are there from directly affected populations to those not directly affected and what factors trigger these spill-overs? and, (3) what are the costs associated with the impacts identified in (1) and (2) for both the private and public health sectors?.

The second study "Sri Lankan Households a Decade after the Indian Ocean Tsunami" investigates this catastrophic event. The long-term impacts of catastrophic disasters are 
inconclusively identified in the previous literature; and so far, there has been very little investigation of household level long-term impacts. In a quasi-experimental fashion, this study examines the consequences of 2004 Indian ocean tsunami on Sri Lankan households in terms of households' income and consumption a decade after the event.

Regarding the recovery from catastrophic disasters, few studies have attempted to unveil the causal connection between disaster recovery and income distribution. This is the key issue considered in the third study "Distributional impacts of disaster recovery: Sri Lankan Households a decade after the 2004 Indian Ocean tsunami". Using quantile difference-indifference methods and examining various inequality measures, the analysis in this chapter provides an account of the recovery, after the tsunami, across different parts of the income distribution and the impact of the recovery process on income distribution at the national and local levels.

\subsection{References}

Berntein, P. L. (1996). Against the Gods: the remarkable story of risk. New York USA: John Willi and Sons Inc.

Central Bank of Sri Lanka (2016), Annual report 2016.

Department of Census and Statistics. (2005). Report on impact of tsunami 2004 on Sri Lanka.

Department of Census and Statistics. (2015). District statistical handbook.

Department of Census and Statistics (2012). Census of population and housing-final report 2013.

Department of Census and Statistics. (2016). Poverty indicators: Household income and expenditure survey - 2015/16. Retrieved from

http://www.statistics.gov.lk/poverty/Poverty\%20Indicators_2016.pdf

Department of Meteorology. (2015). History and overview of Sri Lanka. Retrieved from http://www.meteo.gov.lk/

International Monitory Fund. (2017). IMF data mapper. Retrieved from http://www.imf.org/external/datamapper/PPPPC@WEO/OEMDC/ADVEC/WEOWOR LD/LKA 
IPCC. (2012). Managing the risks of extreme events and disasters to advance climate change adaptation : A Special report of working groups I and II of the Intergovernmental Panel on Climate Change [Field, C.B., V. Barros, T.F. Stocker, D. Qin, D.J. Dokken, K.L. Ebi, M.D. Mastrandrea, K.J. Mach, G.-K. Plattner, S.K. Allen, M. Tignor, and P.M. Midgley (Eds.). Cambridge University Press, Cambridge, UK, and New York, NY, USA, 582 pp.

Ministry of Environment, Sri Lanka. (2010). Sector vulnerability profile: Water. Supplementary document to the climate change adaptation strategy.

The World Bank. (2013). World development report 2014: Risk and opportunity—managing risk for development. Washington, DC: World Bank.

The World Bank. (2016). World development indicators. Retrieved from https://data.worldbank.org/

United Nations Development Programme Sri Lanka (2012). Sri Lanka human development report 2012. Sri Lanka: United Nations Development Programme Sri Lanka.

UNISDR. (2015). Making development sustainable: The future of disaster risk management, Global assessment report on disaster risk reduction. Geneva, Switzerland: United Nations Office for Disaster risk reduction. 


\subsection{Appendices}

Appendix Table 1-1: Cumulative damage of disasters in Sri Lanka (Source: DesInventar data from 1974-2016)

\begin{tabular}{|c|c|c|c|c|c|c|c|c|}
\hline EVENT & DEATHS & INJURED & MISSING & HOUSES DESTROYED & HOUSES DAMAGED & AFFECTED & DAMAGES IN CROPS HA. & Lost Cattle \\
\hline EXPLOSION & 2 & 0 & 0 & 322 & 693 & 15908 & 0 & 0 \\
\hline ROCK FALL & 10 & 12 & 0 & 29 & 128 & 1762 & 0 & 0 \\
\hline TREE FALLEN & 14 & 24 & 0 & 45 & 552 & 2340 & 0 & 0 \\
\hline CHEMICAL & 15 & 6 & 0 & 3 & 0 & 1222 & 0 & 0 \\
\hline LAND SUBSIDENCE & 26 & 19 & 0 & 213 & 5389 & 30958 & 0 & 0 \\
\hline COLLAPSE OF GARBAGE FILL & 64 & 22 & 0 & 120 & 54 & 3340 & 0 & 0 \\
\hline CUTTING FAILURE & 71 & 103 & 0 & 272 & 2159 & 50235 & 0 & 0 \\
\hline STRUCTURE & 107 & 251 & 0 & 8 & 17 & 133 & 0 & 0 \\
\hline SNAKE BITE & 157 & 1 & 0 & 0 & 0 & 90 & 0 & 0 \\
\hline DROWNING & 234 & 24 & 32 & 0 & 0 & 147 & 0 & 0 \\
\hline FIRE & 330 & 1376 & 0 & 5378 & 3070 & 44697 & 0 & 0 \\
\hline EPIDEMIC & 875 & 0 & 0 & 0 & 0 & 1595568 & 0 & 8298240 \\
\hline ANIMAL ATTACK & 2775 & 1673 & 7 & 472 & 24501 & 281186 & 0 & 0 \\
\hline COASTLINE & 0 & 4 & 0 & 330 & 652 & 7549 & 0 & 0 \\
\hline DROUGHT & 0 & 0 & 0 & 0 & 0 & 40543920 & 325549.785 & 0 \\
\hline TORNADO & 0 & 0 & 0 & 75 & 496 & 1280 & 0 & 0 \\
\hline HAILSTORM & 3 & 3 & 0 & 16 & 134 & 1250 & 0 & 0 \\
\hline SURGE & 3 & 0 & 0 & 11 & 153 & 5070 & 0 & 0 \\
\hline TIDAL WAVE & 12 & 2 & 7 & 0 & 0 & 263 & 0 & 0 \\
\hline FLASH FLOOD & 15 & 12 & 6 & 199 & 1854 & 15202 & 0 & 0 \\
\hline EARTH SLIP & 34 & 31 & 21 & 180 & 572 & 9651 & 0 & 0 \\
\hline CYCLONE \& FLOOD & 36 & 48 & 0 & 52712 & 149484 & 1276512 & 0 & 0 \\
\hline GALE & 69 & 439 & 4 & 2632 & 32550 & 233310 & 0 & 0 \\
\hline RAINS & 90 & 586 & 3 & 1436 & 15723 & 2900407 & 0 & 0 \\
\hline STRONG WIND & 468 & 1262 & 133 & 16861 & 130118 & 1233171 & 0 & 0 \\
\hline LIGHTNING & 1251 & 1067 & 9 & 79 & 725 & 5644 & 0 & 0 \\
\hline FLOOD & 1553 & 1032 & 226 & 97752 & 373867 & 33013699 & 27205.755 & 0 \\
\hline LANDSLIDE & 2043 & 868 & 450 & 5563 & 25804 & 642308 & 0 & 0 \\
\hline CYCLONE & 3171 & 1299 & 37 & 37816 & 180696 & 2844641 & 0 & 0 \\
\hline TSUNAMI & 30959 & 19611 & 1908 & 57085 & 48208 & 1076240 & 0 & 0 \\
\hline
\end{tabular}


Appendix Figure 1-1: Socio economic variables and disaster damage over the years
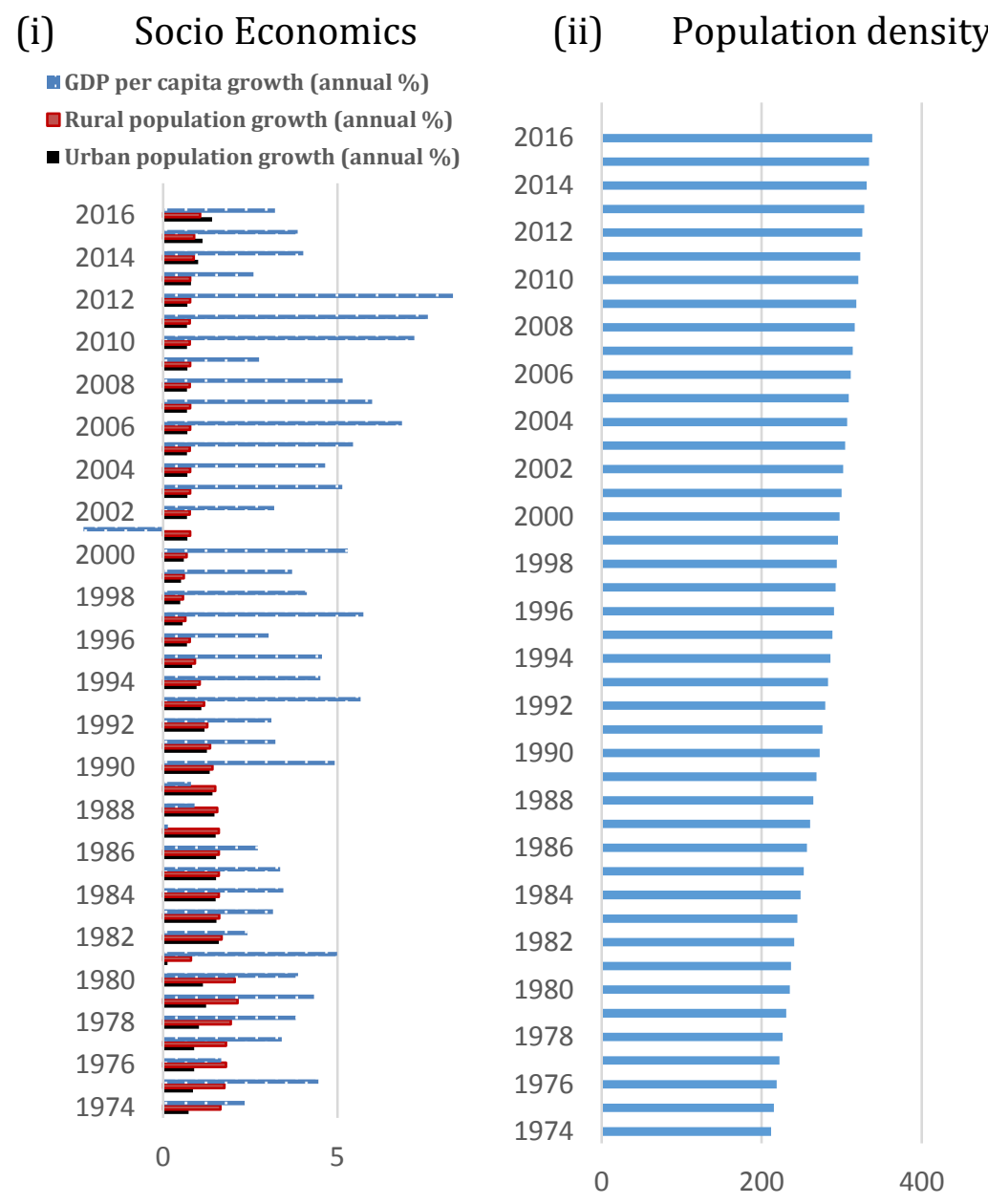
(iii) Disaster
Causalities
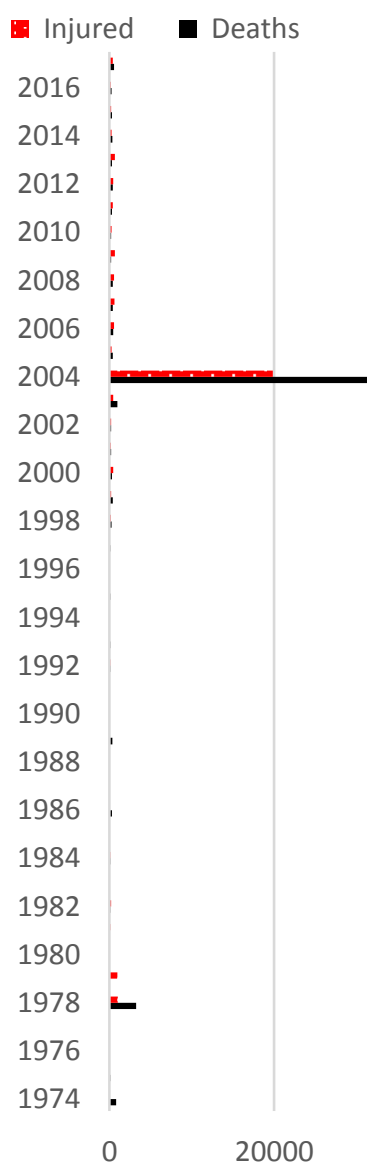

(iv) Disaster Affected Population

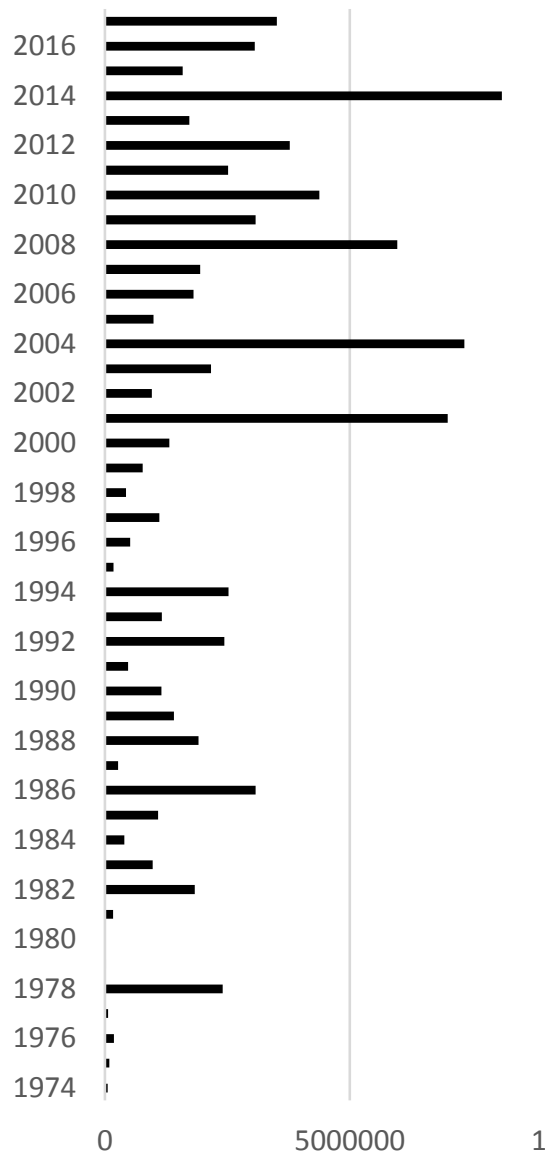




\title{
Chapter Two
}

\section{The Health Care Cost of Being Under the Weather: Droughts, Floods, and Costs in Sri Lanka}

\begin{abstract}
We measure to impact of extreme weather events (droughts and floods) on health care utilization and expenditures in Sri Lanka. We find that frequently occurring local floods and droughts impose a significant risk to health when individuals are exposed directly to these hazards, and also when their communities are exposed, and even if they themselves are unaffected. Those impacts, and especially the indirect spillover effects to households that are not directly affected, are associated with the land-use in the affected regions and with access to sanitation and hygiene. Finally, both direct and indirect risks associated with flood and drought on health have an economic cost; our estimates suggest Sri Lanka spends 19 million USD per year directly on the health care costs associated with floods and droughts, divided almost equally between the public purse and households, and $83 \%$ vs. 17\% between floods and droughts, respectively. In Sri Lanka, both the frequency and the intensity of droughts and floods are likely to increase because of climatic change. Consequently, the health burden associated with these events is only likely to increase.
\end{abstract}




\subsection{Introduction}

Extreme weather events (disasters) can potentially lead to significant and adverse health outcomes. There are myriad ways in which disasters can lead to deterioration of health, and to the economic challenges associated with this deterioration. In many places, climate change is predicted to increase both the frequency and intensity of extreme events such as heat waves, drought, storms and floods (Elsner, et al., 2008; Emanuel, 2005, IPCC, 2014). The costs of the health burden associated with such events could increase as well (Yonson, 2018). This health risk will grow in significance if global warming continues unabated, the economic burden of climate induced health goes unchecked, and investment in avoiding these costs is not made. Maybe surprisingly, there is a paucity of quantitative evidence about the extent of the current cost burden of health risk associated with extreme weather events (Smith et al., 2014; UNISDR, 2011). This paper therefore focuses on the impact of weather risk on health care utilisation and costs (public and private) by focussing on floods and droughts and the health sector in Sri Lanka.

Extreme weather events cause physical injuries, but they also may increase health risks ranging from stress-related ailments, to communicable diseases, to indirect mortality (e.g., Cook et al., 2008; Heutel et al., 2017; Philipsborn et al., 2016). For example, increasing intensity of rainfall and subsequent floods likely elevate the risk of water-borne and vector-borne diseases; while extreme heat can cause deaths due to heat stress and increase the incidence of cardiovascular and respiratory diseases. Droughts decrease production of food, and in poor regions may result in malnutrition and its associated health risks. Floods and droughts can also cause health spill-overs into unaffected populations in disaster-affected regions since the health consequences occur through complex interactions. These interactions include the impaired ability of the health system to reduce these risks and the adverse economic consequences that are borne by indirectly affected households through reduced potential income and the strain on the provision of public services (Smith et al., 2014; Nomura et al., 2016; Noy and Patel, 2014). 
Health consequence can vary with individual characteristics (age, education, income, and occupation), and the community-wide socioeconomic and political context (the health care system, national and international involvement, public security concerns, and public health policy). Land use and ecosystem change, urbanization, trade, and travel are other drivers that can affect the spread of diseases in the aftermath of extreme events (Sutherst, 2004). For example, land use change can increase the risk of infectious diseases (McFarlane et al., 2013; Eisenberg et al., 2007). Higher population densities with inadequate urban infrastructure, changes in vegetation and ground cover, deforestation, and man-made water storage facilities can all determine the link between adverse events and disease spread (Sutherst, 2004; Cheong, et al., 2016; Kweka, et al., 2016, Berazneva and Byker, 2017; Deryugina et al., 2017).

Our analysis uses a cross section of households from the national Sri Lankan household income and expenditure survey of almost 80,000 individuals conducted in 2012-2013. We match this survey data with disaster, meteorological and land use data across the 25 administrative districts in the country to assist us in identifying the links in question. We ultimately aim to quantify the cost burden of the increased provision of healthcare services associated with extreme weather events.

The findings of this paper can also inform us about the additional future cost burden that we should expect should climate-change predictions materialise and lead to significant change in the likelihood and intensity of extreme weather events. Without accounting for these health care costs, we are potentially underestimating the benefits of disaster risk reduction and climate mitigation policies.

The next section discusses the relevant literature, section 3 describes the Sri Lankan context, and section 4 focuses on the methodology and the data used in this study. Sections 5 and 6 describes the results and their robustness, respectively, and section 7 concludes with some relevant caveats and policy implications.

\subsection{Related Literature: The Health Impact of Disasters}

Nomura et al. (2016) found 28 peer-reviewed observational studies on mid- and longterm health impacts of major disasters in the post-acute period (three months or 
more after the event). These address seven health outcomes: mortality (4), suicide (1), mental and behavioural disorders (17), diseases of the circulatory system (4), infectious and parasitic diseases (2), nutritional diseases (1) and biometric measures such as blood pressure (4). In their meta-study, these health impacts are influenced by thirty-five factors related to the socioeconomic and political context, personal characteristics, and intermediating factors (e.g., behavioural responses, health system functioning, sanitation, food supply, and psycho-social circumstances). In Appendix $2-1$, we describe in detail the main diseases relating to both inpatient and outpatient treatments in Sri Lanka, and the related epidemiological literature that examined the determinants of disease outbreaks.

Ultimately, we are interested in the economic burden that disasters impose via the increasing incidence of diseases and the increasing need to provide both inpatient and outpatient health services. In Sri Lanka, health is generally a non-market sector, so that market prices rarely exist, and deriving cost is not straightforward. Studies in health economics, however, attempt to understand the total welfare cost of health care in terms of three components: the resource costs (the costs and health and nonhealth goods and services used in medical treatments); the lost productivity due to illness; and the disutility that accompanies many inflictions (the experienced pain and inconvenience).

When deriving the health costs of infectious diseases, a number of studies focusing on Malaria found substantial increase in household and public-sector expenditure for prevention and treatment. For example, a couple of studies identified a decrease in labour inputs and low school attendance due to Malaria (Chima, Goodman and Mills, 2003; Malancy, Spielman and Sachs, 2004). Bleakley (2010) observed higher earnings among people who were born just after the eradication of malaria in United States enabling a calculation of the previous cost associated with malaria there. Using the estimated costs of the disease, and assuming these as a benefit should the disease be prevented, others calculate the benefit cost ratios for malarial prevention interventions (e.g., Mills and Shillcutt, 2004). 
Another strand of this literature examined pandemics. For example, Smith et al. (2009) modelled the economic impact of influenza in the UK, while another study examined the impact on income associated with an outbreak of SARS (Keogh-Brown and Smith, 2008). Research in poorer countries identified, for example, the direct cost of illness due to water-borne diseases in Pakistan or the overall economic burden of water-borne diseases in Kiribati in the South Pacific (Malik, Tabinda and Abubakar, 2012; and Asian Development Bank [ADB], 2014, respectively).

There is, however, only a limited amount of work evaluating the health cost burden associated specifically with extreme natural hazard events such as floods and droughts (Merson, Black and Mills, 2006; IPCC, 2014; Del, Jones and Olken, 2014). Among the available literature, there are three types of studies: on health impact, on adaptation costs and health economic evaluation studies. This last strand uses different monetary valuation methods such as the value of statistical life, disabilityadjusted life years, treatment cost estimations, household health expenditure measures, and preventive health provision cost estimates.

For example, when isolating the health impact of a one degree (Celsius) increase in global annual temperature, Bosello, Roson and Tol, (2006) estimate the costs for attributed cases using a multi-country general-equilibrium model. The mortality due to vector-borne diseases (such as malaria, dengue, and schistosomiasis) is calculated first using temperature, diseases and associated mortality risks as parametrised in previous studies and then calculating the associated health costs in terms of death avoidance using treatment costs as reported by WHO. These provide inputs into their general-equilibrium model. Kovats, Lloyd, and Watkiss (2011) also use a modelling approach to estimate the marginal effect of climate change in 27 European Union countries by: quantifying the value of lives lost due to heat mortality, additional cases of salmonella and fatalities due to coastal flood.

The estimates that are produced from these models inevitably depend on the many assumptions associated with the construction of these models. Statistical quantification of observed data provides a different approach that is less structural 
and assumption-dependent. Knowlton, Rotkin-Ellman, Geballe, Max and Solomon (2011), for example, attempt to calculate the cost of health impacts associated with events that can be related to climate change - ozone air pollution, heat waves, hurricanes, outbreak of infectious diseases, river flooding and wildfires - over a decade in United States. Mortality and morbidity from such events are measured using epidemiological studies, aggregate public health data and extrapolations when required. These are then matched with statistical estimates of the value of life, medical care costs, and lost productivity.

In low- and middle-income countries, micro-empirical approaches are more common, and probably more accurate. Lohmann \& Lechtenfeld (2015), for example, empirically estimate the household level impact of drought on health expenditure in Vietnam by first estimating an illness and drought shock model, aggregating drought associates illnesses at the household level and then regressing household health expenditure on the instrumented illness measure. This study identified a 9-17\% health expenditure burden on households that is due to drought-related health shocks. Our study uses a similar micro econometric approach to reveal more insights into the health economic impact of flood and drought at the spatial individual household level.

Another segment of the literature estimates the costs of adaptations to climate change related health impacts: preventing treatment cost of diarrhoea cases for Europe and Central Asia (World health Organization [WHO], 2013), total net cost saving in disease treatment (Agrawal, Bosello, Carraro, and De Cian, 2009) and preventing risk of malaria and diarrhoeal diseases using preventive service cost in Europe (Ebi, 2008), evaluation of cardiovascular respiratory diseases treatment due to air pollution (Hutton, 2008), and water borne diseases vaccination programs (Goossens et al., 2008; Melliez et al., 2008).

\subsection{Background on Natural Hazards and Health in Sri Lanka}

Sri Lanka has a land area of $65,610 \mathrm{~km}^{2}$. Rainfall is largely associated with tropical monsoons, but rain also occurs in other seasons. The mean annual rainfall varies from 
under $900 \mathrm{~mm}$ in the driest parts (South-Eastern and North-Western) to over $5000 \mathrm{~mm}$ in the wettest parts (Western slopes of the Central Highlands). The mean annual temperature of the lowlands varies between $26.5{ }^{\circ} \mathrm{C}$ to $28.5{ }^{\circ} \mathrm{C}$. In the highlands, the temperature can fall to $15.9^{\circ} \mathrm{C}$ (Department of Meteorology, 2015). ${ }^{1}$ The country has an irregular topography comprising a broad coastal plain and a central mountainous area rising to elevations of $2,500 \mathrm{~m}$. This topography and differences in regional climates are underlying causes of the variation in agroecological zones that are identified depending on variation in rainfall and its seasonal distribution, soil, and altitude. $33 \%$ of the land is covered with forest, $43 \%$ is used for agriculture (permanent and temporary crops), $4.4 \%$ is of surface water bodies ${ }^{2}$ (World Data Atlas, 2014).

Sri Lanka is affected by numerous disasters. The most frequent weather-related disasters are floods, cyclones, and droughts. For 1974-2008, the Sri Lankan government reported 1397 flood events, 1,263 events of cyclones, strong winds, surges, and gales and 285 drought events (Disaster Management Centre, 2010). ${ }^{3}$ The seasonal distribution of floods shows two peaks: one from April to June and the other from October to December, representing the two monsoon seasons.

Sri Lanka is a lower middle-income country, with per capita income 13,800 US\$ (PPP) (IMF, 2016) and a population of 20.9 million (World Bank, 2015). Sri Lanka has made considerable progress on immunization against infectious diseases; still, the most prevalent infectious diseases in recent years include vector borne ones such as

\footnotetext{
${ }^{1}$ The island is divided into three climatic zones, based on the annual rainfall: Dry Zone, Wet Zone, and Intermediate Zone. The location of the south-central highlands causes interception of monsoonal rains from the southwest and creates a 'rain shadow' on the other side. This has given rise to an ever-wet region which receives abundant rainfall from two monsoons and a Dry Zone that receives rainfall from only the north-east monsoon. The north-east dry zone is characterized by long spells of drought during other months.

2 Sri Lanka has many major river basins, as well as a large number of man-made reservoirs.

3 By far the worst disaster experienced in Sri Lanka since its independence was the Boxing Day Tsunami in 2004 (following an earthquake in Indonesia). Details about this event are available from numerous sources. De Alwis and Noy (2016) document the tsunami's long-term impact on Sri Lankan households.
} 
dengue, and leptospirosis, and diseases transmitted orally through contamination of food or water, such as diarrhoea (dysentery), hepatitis, and typhoid fever (Ministry of Health, 2012a , 2012b ). 18\% of the population suffers from chronic diseases and 15\% from acute diseases (UN, 2014; Department of Census and Statistics, 2014).

The government reported more than 64,000 cases of Dengue, a mosquito born viral disease, in 2012-13, with 270 reported deaths. Leptospirosis is the second highprevalence disease as reported. Caused by bacteria and transmitted mainly by rodents it caused almost 7000 cases and almost 100 deaths in the same time period (Ministry of health, 2012a and 2013). Outbreaks of both of these are reported more during the high-rainfall months and recently, 33673 dengue cases reported during the first five months in 2017 (Sri Lanka Dengue Control Unit). Mums, Measles, and Chicken Pox are the other most common infectious diseases. The national communicable disease surveillance undertaken in 2012 also reported 80,660 outpatient visits for influenza-like illnesses and 2580 inpatients for severe respiratory tract infections (Ministry of health, 2012b). In Sri Lanka, for the last few years, influenza has been generally observed during April to June and again in November to January. 4

Health care in Sri Lanka is mainly provided by the public sector. Total health expenditure accounts for 3.3\% of total GDP. According to the World Bank data (2015), it is comparable to the health expenditure of countries such as Bangladesh and the Philippines that are in the same income category, and upper-middle income countries such as Fiji and Thailand. The government health sector is predominantly financed from general revenue taxation, while private sector financing is from out-of-pocket spending, private insurance, and enterprise direct payments, insurance paid for by enterprises, and contributions from non-profit organizations. Public sector healthcare is universally accessible to the entire population and is almost wholly free of charge. Annual per capita total expenditure (from all sources) is Rs. 13,666 for which the government contribution is Rs. 8037 (Institute of Health policy, 2015). As

\footnotetext{
${ }^{4}$ Sri Lanka faced an outbreak of influenza (mainly due to the H1N1 virus) in 2015, causing 74 deaths (WHO, 2015).
} 
per the national health accounts in 2013, the largest share is attributed to the treatment of non-communicable diseases (35\%) followed by infectious and parasitic diseases (22\%). Reproductive health services accounted for nearly $10 \%$ of health expenditures, while injuries require $7.7 \%$. Classified by the way it is delivered and based on government health sector data, inpatient care accounts for $37.1 \%$ of total health expenditure by the public sector and outpatient treatment with medical products (e.g., medicines) is $46.5 \%$. Inpatient care is mainly provided by the government sector (Institute of Health policy, 2015).

In this context, this study attempts to:

1. Quantify the individual health risk attributable to flood and droughts.

2. Quantify health spillovers from flood and drought affected populations to those not directly affected and identify the associated trigger factors.

3. Identify the costs associated with the health-related disaster impacts identified in (1) and (2) for both the private and public health sectors.

\subsection{Data and Methodology}

Our data come from the National Household Income and Expenditure Survey conducted between June 2012 and July 2013. The data include information on whether each household member received inpatient hospital treatment in the past year and visited a hospital (private or public) for outpatient treatment in the previous month. ${ }^{5}$ The survey questionnaire also posed a question on whether the households were affected in the past year by flood or drought. We combine this data with flood and drought information compiled in a separate national database (Desinventar Sri Lanka) to identify our treatment variables for each district - i.e., whether districts were affected by flood and drought in the past year or in the month before the HIES

\footnotetext{
${ }^{5}$ In a survey about health expenditure surveys, Xu et al. (2009) specify the standard for recall as one month for frequent health expenditures and one year for infrequent ones, including hospitilizations. As such, the Sri Lanka survey follows the global practice. O'Donnell et al. (2008) investigate health expenditures in Asia and argue that recall mistakes most likely do not bias their estimations (i.e., they are not systematically biased).
} 
survey was undertaken in the 25 administrative districts across the country. District level land use data come from the district profiles maintained by the Sri Lanka Census and Statistics Department. We also use district land use data to identify how land-use affects flood and drought induced health impacts.

The summary statistics for our sample (Table 2-1) show that $28 \%$ of household members sought outpatient treatment in the previous month and $9 \%$ sought inpatient treatment in the previous year. 6 \% reported themselves as affected by flood and 3\% by drought in the past year. $11 \%(14 \%)$ reside in the districts affected by floods (droughts) in the month before the survey was conducted. ${ }^{7}$

We estimate individual (inpatient and outpatient) health impacts using a probit model specification. Our outcome variable is a binomial response for inpatient or outpatient visit for treatment. The empirical model specification is:

$Y_{i d}=\beta_{1} Z_{i d}+\beta_{2} D_{i d}+\beta_{3} D_{S p i l l_{i d}}+\beta_{5}\left[Z_{i d} * D_{i d}\right]+\beta_{6}\left[Z_{i d} * \operatorname{DSpill}_{i d}\right]+\delta_{m}+\gamma_{d}+$ $U_{i d}$

In the benchmark model, $Y_{i d}$ is the dependent variable - a dummy variable for hospital inpatient or outpatient treatment; the unit observed is for household $i$, in district $d . D_{i d}$ is the flood/drought (a 'treatment' binary indicator) variable, demographic and household covariates. $Z_{i d}$ are incorporated to control for heterogeneity of health outcomes due to structural factors. To control for seasonality, the month fixed effects $\left(\delta_{m}\right)$ and to control for district heterogeneity, district fixed effects are incorporated $\left(\gamma_{d}\right)$ in some of the reported specifications (when the districtlevel land-use measures $X_{d}$ are not included). The coefficient of interest is $\beta_{2}$, denotes

\footnotetext{
${ }^{6}$ Inpatient care generally refers to any medical service that requires admission into a hospital, and is typical for more serious ailments and trauma. Outpatient care, on the other hand, is any medical service that does not require a prolonged stay at a facility. This can include routine services such as check-ups or visits to clinics (even more involved procedures such as surgical procedures, so long as they allow the patient to leave the hospital or facility on the same day).

7 Thus, the majority of residents of affected districts do not reported being affected by either floods or droughts. For floods, it might be that these non-affected households resided further away from waterways and reservoirs that were flooded. For droughts, it might be that they resided in areas of the district that were less affected by drought, that their agricultural land is irrigated, or that they do not work in agriculture, and therefore the drought had no direct observable impact on their lives.
} 
the marginal effect of flood and drought on the probability of needing inpatient or outpatient treatment. $U_{i d}$ controls for unobserved variation, and is assumed iid with mean zero. To isolate the health vulnerability to flood and drought based on structural factors (age groups, rural and urban sector, household sanitation), model specifications incorporating the interaction of treatment with structural factors $\beta_{5}\left[Z_{i d} * D_{i d}\right]+\beta_{6}\left[Z_{i d} * D S p i l l_{i d}\right]$ are estimated.

As the health impacts associated with disasters are hypothesized to be mediated through other characteristics (vulnerabilities such as limited household sanitation), these can also affect households that are not directly impacted. These spillovers may lead to impaired health outcomes for people who are not directly affected by the flood/drought but live in the vicinity of directly affected households. To identify the health spillovers, we estimate the model including a variable ( Spill $\left._{i d}\right)$ that defines a separate treatment group for those people who live in flood or drought affected districts but did not self-report as being affected by flood or drought (respectively) in the survey questionnaire. $\beta_{3}$ is the coefficient of interest to quantity the indirect health spillovers associated with these natural hazards. To identify how land-use factors may induce disaster-triggered health risk, we incorporated these into the estimation as well; in these specifications, the district fixed effects are replaced with these district-level measures $\left(X_{d}\right)$.

$Y_{i d}=\beta_{1} Z_{i d}+\beta_{2} D_{i d}+\beta_{3} \operatorname{DSpill}_{i d}+\beta_{4} X_{d}+\beta_{5}\left[Z_{i d} X_{d} * D_{i d}\right]+\beta_{6}\left[Z_{i d} X_{d} * \operatorname{DSpill}_{i d}\right]+$ $U_{i d}$

To identify how the external household-specific and district-level factors may induce disaster-triggered health risk, we incorporated these into the estimation in several interaction terms. In these specifications in Equation 2, interaction terms of the disaster measure and the district-level factors are also introduced to the model $\left(Z_{i d} X_{d} * D_{i d}\right)$ to examine the causal connection between these variables and disaster exposure and with the disaster spillover indicator $\left(Z_{i d} X_{d} * D S p i l l_{i d}\right) \cdot \beta_{5}$ and $\beta_{6}$ are 
therefore the coefficients of interest in Equation 2 that identify the answer to our second question. ${ }^{8}$

Unfortunately, interpreting interactions terms in non-linear regressions is not straight forward, as the marginal impact of a variable depends on the values that other variables take. In fact, even the sign of the coefficient of the interaction term may depend on the level of other independent variables, and may even change along their distribution (Hoetker, 2007). We present our results, with regards to the interaction effects, in a series of graphs that describe the marginal effect at various points. To construct these figures, we employ the STATA command routine developed and described in Norton, Wang, and Ai (2004).

In order to estimate the private cost of health impacts due to natural hazards we use the household health expenditure data collected in the survey. Most of the provision of health care in Sri Lanka is done through the public service (which is free). However, many households choose to use instead the private sector (because of queues for specialists or because of a perceived difference in the quality of service) and a lot of the expenditure on medicines is paid privately. The monthly household health expenditure for a member experiencing inpatient treatment (at least once in last year) and receiving outpatient treatment (in the past month) is derived from estimating the household health expenditure model below (3). $Y_{h d}$ is the household health expenditure and $I_{\text {ind }}$ is the inpatients/outpatients $i$ in family $h$ and district $d . \gamma_{d}$ is the district dummies to control for district heterogeneity in health costs. Using equation (3) we can then estimate the average private health care costs associated with both inpatient and outpatient treatment.

$$
Y_{h d}=\beta_{1}+\beta_{2} X_{\text {ihd }}+\beta_{3} I_{\text {ihd }}+\gamma_{d}+U_{\text {id }}
$$

Finally, the total public costs of health due to flood and drought are calculated using the average per capita public health expenditure for inpatient and outpatient

\footnotetext{
${ }^{8} \mathrm{We}$ also estimated a more restricted model: $Y_{i d}=\beta_{1}+\beta_{2} Z_{i d}+\beta_{3} D_{i d}+\gamma_{d}+U_{i d}$ that does not include the hypothesized spillover effects (directly unaffected households that reside in affected districts). Results for these regressions are available from the online appendix:

https://sites.google.com/site/noyeconomics/research/natural-disasters.
} 
treatment in each district. These numbers are reported in the national health accounts of Sri Lanka (Institute for Health Policy, 2015).

In the last step, the marginal effects estimated in our models are used to predict the number of inpatients and outpatients associated with extreme weather events at the district level. The estimated figures are used in conjunction with the per capita public and private health expenditure costs, estimated as described above in Equation 3, to calculate the overall health care costs of floods and droughts for each Sri Lankan district.

We note that our main identifying assumption, if we were to argue that causality is identified, would be to assume that the shocks are randomly distributed. Since, obviously, some areas are more prone to disasters than others, that assumption is too restrictive, and it is possible that people 'sort out' according to their willingness to take on disaster risk. Since mobility is not that high, especially in between rural areas, we do not believe that this is a major source for bias in our estimates. ${ }^{9}$ Still, a strict interpretation of our model would argue that we are identifying only correlations between disaster occurrence and health care utilisation. We retain this interpretation in what follows.

\subsection{Results}

We estimate our models (1) and (2) separately for inpatient and outpatient care. Table 2-2 provides the results for the inpatient-model based on Equation (1), Table 2-3 does the same for the inpatient-Equation (2) results, while Tables 2-4 and appendix table 2-11 do the same for outpatient services (Equations (1) and (2), respectively). All of these are discussed separately in each of the sections below.

\subsubsection{Health impacts of extreme weather: Inpatient care}

Estimates of the parameters for equation (1) are provided in Table 2-2. In all columns, controls for demographic factors are included, and results for their coefficients are

\footnotetext{
${ }^{9}$ There is significant movement of people from rural areas to the urban centers.
} 
presented in the online appendix accompanying this publication. The basic specifications, including the self-reported and spillover flood and drought binary indicators, are presented in columns (i) and (ii); including month-fixed-effects in column (ii). In these results, we find that being directly affected by floods, or living in a community affected by floods, increases the probability of needing inpatient care by about 2 percentage points, while the impact of being directly affected by a drought are about double that.

Column (iii)-(vi) in Table 2-2 include the hygienic factors (shared or public toilet indicators and access to drinking water) and combinations of month and district fixed effects. Consistently through the estimations in columns (iii)-(v), we observe that the likelihood of receiving inpatient treatments associated with direct exposure to flooding increases by about 2 percentage points (pp). The spillover risk, once we control for other factors, is lower (about $1 \mathrm{pp}$ ) and less consistently estimated. The reliance on either shared or public toilets (the default being private ones) is estimated to be associated with increased inpatient treatment, while the same is estimated for drinking water being available only from wells. Surprisingly, unsafe drinking water (as reported in the survey) is not associated with increased use of inpatient services. The presence of water bodies is investigated in column (vi); we find that reservoirs are associated with increased use of inpatient care, but the magnitude of this coefficient is quite small. We find no association between the presence of natural water bodies and inpatient services.

In table 2-3, we separate the population sample we have into several sub-samples and estimate these separately. In particular, we estimate separately the rural households, the urban households, and those residing in estates (the first three columns in table 2-3). In the last two sub-samples (columns 4-5), we separate the sample according to age (at the median age). Maybe not surprisingly, the impact of floods is higher for rural households than it is for the urban ones, in terms of inpatient health treatments. This is also true for droughts, though the coefficient estimates in the rural column are not statistically significant. Surprisingly, the drought spill-over indicator is twice as large for the urban sample than it is for the rural one (and is statistically significant). 
More important than these distinctions between rural and urban are the estimated coefficients in the estate sector. These are much larger for droughts, suggesting that this population, already the poorest and most dis-advantaged, also suffers from much higher need for inpatient care as a consequence of droughts (and spillover from floods). Also notable is that, for the population in the estate sector, the impact of the hygiene and water variables are also both larger and more statistically significant. This last observation about statistical significance is surprising as the size of the estate sample is much smaller - this is a further indication of the intensity of natural hazard impacts on health utilization in the estate sector.

The differences between the estimated coefficients for the young and old populations are less pronounced. However, we do note that the impact of both hazards on inpatient health services use appears to be higher for the older sub-sample; and also, more statistically significant.

In an additional set of regressions, we investigate the interaction effects of the occurrence of floods and droughts, with these hygiene and water controls. The interpretation of interaction effects in limited dependent variable models is more involved and, as Norton et al. (2004) show, frequently mis-estimated and misunderstood. We follow their recommendation and present these results in a series of graphs discussed in section 2.5.3.

\subsubsection{Health impacts of extreme weather: Outpatient care}

Table 2-4 presents floods and droughts' impact on the likelihood of outpatient treatment similarly to the presentation of results for inpatient hospitalizations in the previous table (Table 2-2). Here, the dependent variable is whether a household member used outpatient services in the previous month and the main variable of interest is whether districtwide flood occurred during that the same month. We no longer have the data available to allow us to separate those that were directly and indirectly (spillovers) affected. 
Unlike the earlier results (for inpatient care), we no longer observe that households that live in a district that was flooded are significantly more likely to require outpatient services. The results in all the regressions for the district-wide flood measure are always statistically insignificantly different from zero. One possibility for explaining this lack of statistical significance is that our flood indictor is no longer identified precisely, so that it erroneously identifies many households that were not, in reality, affected by floods.

Droughts are a more spatially wide-spread hazard, and therefore our identifying independent variable (districtwide exposure) is more relevant in this context. We indeed find more consistent finding for the drought-treatment variable; the coefficient in most of the estimates is both statistically and economically significant, with droughts increasing the likelihood of outpatient treatment in the following month by 1-4 pp. It is, however, important to note that once we estimate the full model with all controls, neither the flood nor the drought indicators retain their statistical significance.

The estimated model consistently shows that households that share toilet facilities with other families are at a significantly higher risk of requiring outpatient health treatment (irrespective of their weather hazard exposure). When households do not possess in-house source for drinking water, the evidence of their need for outpatient health services is less consistent (all in columns iii-vi). Where the presence of water bodies is included in the estimation, the presence of human-made reservoirs is associated with increased probability of requiring outpatient health care services, while the presence of natural water bodies is associated with the opposite (in both cases the results are statistically significant, and not very large; column vi).

\subsubsection{Interactions of the hazard variables with hygiene controls}

As stated earlier, the magnitude and even sign of the interaction effects is difficult to present since, in non-linear models, it depends on the level of all the variables. As suggested by Norton et al. (2004), the easiest way to present these interactions is through a series of graphs where the coefficient size is presented on the vertical axis 
while the estimated probability of the event (in this case seeking inpatient or outpatient care) is presented on the horizontal axis. We note that there might be multiple combinations of independent variable that lead to a similar estimated probability, and the size of the interaction coefficient associated with each one of these combinations might be different.

These interactions effect for inpatient care are presented in figure 2-1. In each case, the companion figure to each of the estimated interaction effect (per estimated probability) describes the statistical significance of these results, with the $5 \%$ significance threshold noted in the graph. Examining the inpatient model, for example, the interaction between having shared toilets and being affected by floods (self-reported) appear to be negative, but it is not statistically significant for any estimated probability. More nuanced, and more difficult to interpret, is the interaction effect between the same flood-affected measure and having access to a public toilet. In this case, the results appear to be statistically significant for estimated probabilities $>0.2$, but the sign of the coefficient associated with this interaction can be either negative or positive for different combinations of the independent variables yielding these larger estimated probabilities.

Overall, in most cases the estimated interactions effects are not consistently statistically significant and of the same sign all across the range of associated probabilities. Exceptions are few but worth noting. A household that is indirectly affected by flooding and has access only to a well or unsafe drinking water is facing a higher likelihood of needing inpatient care, for the whole distribution of estimated probabilities. Rural households that are exposed to flood risk also appear to experience much larger impacts (this is a result we only reported using different subsamples in table 2-3).

Figure available in the online appendix 2-13, presents the interaction effects for outpatient care. In this case, none of the interaction effects are statistically significant. This might be because there are no interactions, or because our identification of 
hazard exposure at the district level is not precise enough, as we discussed in previous section (section 2.5.2).

\subsubsection{District-level health cost of flood and drought}

Table 2-5 provides information about the estimation specification described in equation (3). In these, we estimate the average increase in health expenditures at the household level associated with an episode of inpatient or outpatient health service utilisation. Not very surprisingly, we note that inpatient care is on average about three times as costly, for the household, as is outpatient care (column iii). Other interesting observations that arise out of these estimates is that the expenditure associated with males and older patients are higher (on average). Households with higher socioeconomic status (better educated, belonging to the Sinhalese majority, having higher income, and being urban) are all associated with more health expenditures. Especially low expenditures are associate with the estate (plantation) sector, and maybe obviously, those that live in communities that are more distant from hospitals. We note that while all of these results are statistically significant, the overall explanatory power of the model is quite minimal.

In order to assess the overall costs associated with the health services provided to the hazard-impacted population, we need to measure the population's vulnerability to flood and drought-caused utilization of health services across districts; these estimates are provided in table 2-6. These district level population vulnerability to adverse health due to flood and drought is calculated by multiplying the district population and the point estimates of the disaster shock variable (marginal effect of flood and drought on health services utilization) as estimated in the regressions detailed above.

Table 2-7 shows the total cost estimate due to drought and flood, separated for the costs associated with the private and public sectors. The estimations are based on Sri Lanka population census of 2012. Public health costs are based on the reported district level per capita health expenditure; while the private costs were estimated in 
table 2-5. The estimated realization of the district level health burden is derived from the population in each district in each year and from whether districts were actually exposed to flood and drought in the same year. Finally, the appendix also presents the same results on a map of Sri Lanka, identifying the costs associated with both inpatient and outpatient care at the district level, and in per capita terms.

\subsection{Robustness}

The self-reported binary treatment variable we use does not provide detailed information on the severity of the treatment. It is also possible that self-reported treatment is motivated by factors other than the damage intensity, such as the hope of becoming eligible for disaster relief, and might therefore be inaccurate. ${ }^{10}$ When examined against district level administrative data on disasters, the self-reported treatment indicator matches well - all affected districts reported were also locations where people self-reported as affected. ${ }^{11}$ Certain self-reported households, however, were in districts that are not reported as disaster affected in the administrative data. This is not necessarily an indication of any mis-reporting, as the aggregate datasets are frequently criticised for not including in their reporting local events that were destructive in a very limited geographic area and therefore did not cause that much damage in the aggregate (even if the loss for affected households was very high). The district level flood and drought impact reported in the administrative data is reasonably matched with the district level rainfall data and accordingly, provides further evidence that the treatment variable we use is not overtly biased. We also include specifications, in the appendix 2-12, that use measured rainfall data and linear probability model in appendix table 2-10; the results of these specifications (when treatment is identified by district measure) are very similar.

\footnotetext{
${ }^{10}$ In reality, of course, the survey and the disaster relief program are completely independent from each other. The two programmes are implemented by different administrative authorities reporting to different ministries.

${ }^{11}$ This conclusion is in contrast with a finding from Bangladesh, where the congruence between self-reports and objective observations is less reassuring (Guiteras et al., 2015).
} 
Similarly, there may be problems with the self-reported health outcome variable used in the analysis. It provides only limited information as it reported health outcome at least once in the past year even though more than one health outcomes (inpatient treatment, outpatient visits) could have occurred within that year. This can cause under estimation of the health risk due to disasters in our analysis. The estimated costs of healthcare post-disaster may still be biased if frequently affected households take (costly) adaptation measures or if frequent disasters cause people to relocate to other areas. If adaptation is similar at the district level, the district fixed effects in our model control for any district level adaptations.

\subsection{Conclusions, Caveats, and Climate Change}

This study sat out to determine the economic costs associated with extreme weather impacts on healthcare. The most obvious finding emerging from our analysis is that frequently occurring local floods and droughts appear to impose a significant health risk to individuals' health when they are exposed directly to these hazards, and that this sometime requires is even associated with higher rates hospitalization. Those impacts, and especially the indirect spillover effects to households that are not directly affected by the hazard, are at least partly associated with land use in the affected environs of the hazard, and with the household's access to sanitation and hygiene. Why sanitation and hygiene are important in mediating the impact of floods and droughts probably does not need explaining. The most likely causal story to our observations about land-use interacting with both floods and droughts is that both drought and floods lead to a higher likelihood of contaminants and infections being transmitted (most likely orally) when human-made reservoirs are prevalent in the affected area as they interact with the water available for human consumption. ${ }^{12}$ The health spillovers we identified almost always appear to be associated with the household sanitation and hygienic conditions. Flood health spillovers are associated with the households using unsafe drinking water sources (wells and other unsafe sources). It seems that flooding increases the likelihood of contamination of public

\footnotetext{
${ }^{12}$ It is important to note that Sri Lanka has many human-made reservoirs, some dating back many centuries.
} 
water sources. Other possible epidemiological explanations for our spillover finding is the increased presence of disease transmitting vectors (e.g., mosquitos) in the aftermath of floods, an increase that affects also households that were not directly damaged by the event.

Finally, both direct and indirect risks of flood and drought on individual health has an economic cost associated with it, with a consequent welfare loss. Overall, our estimates suggest Sri Lanka spends 19 million USD per year on health care costs associated with floods and droughts, divided almost equally between the public and household sectors, and $83 \%$ vs. $17 \%$ between floods and droughts. Worryingly, our calculations show that the health burden is distributed spatially so that the highest health burden due to flood and drought is born by Western and Central provinces followed by Southern and North western provinces. The total per capita burden is almost equal across all regions. The Western province is the richest region in the country; it has nearly double the monthly per capita income, and it also bears the highest health burden associated with floods and droughts. (Appendix 2-14).

It is worth noting that the estimated health-expenditure burden quantified in this paper is only a part of the full economic cost of this health burden. The cost in this paper is estimated in terms of direct public and household expenditure on disease treatment not the full accounting of costs. Underestimation of actual costs is likely since household members presumably experience reduced productivity and reduced ability to generate income during their treatment. Equally, the opportunity cost of government spending resources on these health costs is probably substantial, as the opportunities for more productive fiscal expenditures are more numerous in countries with low capital base and one that is rapidly developing (as is the case in Sri Lanka). Our estimated drought effect may also be underestimated since droughts cause longer term effects beyond one year while our estimates focus only on same year health expenditures.

Finally, regional climate model projections for future temperature predict increases for Sri Lanka: $1.0^{\circ} \mathrm{C}-1.1^{\circ} \mathrm{C}$ by 2030 , and $2.3^{\circ} \mathrm{C}-3.6^{\circ} \mathrm{C}$ by 2080 . Accordingly, 
precipitation is likely to increase by $3.6 \%-11.0 \%$ by 2030 , and $31.3 \%-39.6 \%$ by 2080 (Ammed and Suphachalasai, 2014). Studies also predict higher frequencies of high intensity rainfall events causing floods and dry periods generating drought conditions (Ministry of Environment, 2010). In short, both the frequency and the intensity of droughts and floods are projected to increase because of climatic change, though the magnitude of these increases is as yet unknown. Consequently, the health burden of these events is only likely to increase, further demanding precious resources that are required elsewhere in a rapidly growing but still relatively poor country. 
Table 2-1 Data Summary

\begin{tabular}{|c|c|c|c|c|}
\hline Variables & Mean & Std. Dev. & Min & Max \\
\hline Sex (Dummy for Male=1) & 0.48 & 0.50 & 0 & 1 \\
\hline Age (years) & 32.6 & 21.5 & 0 & 99 \\
\hline Education (years) & 8 & 4.7 & 0 & 19 \\
\hline Ethnicity_Singhalese (Dummy) & 0.65 & 0.48 & 0 & 1 \\
\hline Ethnicity_Tamil (Dummy) & 0.34 & 0.47 & 0 & 1 \\
\hline Employed (Dummy) & 0.23 & 0.42 & 0 & 1 \\
\hline Employer(Dummy) & 0.01 & 0.80 & 0 & 1 \\
\hline Own family worker(Dummy) & 0.12 & 0.33 & 0 & 1 \\
\hline Reside in Rural sector(Dummy) & 0.65 & 0.48 & 0 & 1 \\
\hline Reside in Estate sector(Dummy) & 0.10 & 0.29 & 0 & 1 \\
\hline Outpatient visit at least once last month & 0.28 & 0.45 & 0 & 1 \\
\hline Inpatients visit at least once last year & 0.09 & 0.28 & 0 & 1 \\
\hline Flood affected last year (Dummy for Self-Reported) & 0.04 & 0.20 & 0 & 1 \\
\hline Flood affected last year (Dummy district wide flood) & 0.72 & 0.45 & 0 & 1 \\
\hline Drought affected (Dummy for Self-reported) & 0.03 & 0.17 & 0 & 1 \\
\hline Drought affected last year (in affected District) & 0.32 & 0.47 & 0 & 1 \\
\hline Flood affected last month (in affected District) & 0.11 & 0.31 & 0 & 1 \\
\hline Drought affected last month (in affected District) & 0.14 & 0.35 & 0 & 1 \\
\hline Flood spill-over & 30 & 46 & 0 & 1 \\
\hline Drought spill-over & 68 & 46 & 0 & 1 \\
\hline Households_Toilet shared (Dummy) & 0.06 & 0.24 & 0 & 1 \\
\hline Households_Toilet Public(Dummy) & 0.04 & 0.19 & 0 & 1 \\
\hline Households_Drinking water_Well(Dummy) & 0.48 & 0.49 & 0 & 1 \\
\hline Households_Drinking water_Open sources(Dummy) & 0.18 & 0.38 & 0 & 1 \\
\hline Agricultural water retention area ( $\%$ of land in district) & 11.09 & 5.73 & 0 & 23.7 \\
\hline Natural water retention area ( $\%$ of land in district) & 4.98 & 3.24 & 0 & 18.6 \\
\hline Household income & 29790 & 31656 & -3750 & 324275 \\
\hline Household health expenditure & 1544 & 13645 & 0 & 1103400 \\
\hline
\end{tabular}

Note: There are 79,381 observations. 
Table 2-2 Health impacts of floods and droughts: Inpatient health treatments

\begin{tabular}{|c|c|c|c|c|c|c|c|c|c|c|c|c|}
\hline Variables & (i) & & (ii) & & (iii) & & (iv) & & (v) & & (vi) & \\
\hline Self-reported flood (Dummy) & $0.02^{*}$ & $(0.01)$ & $0.02^{*}$ & $(0.01)$ & $0.02^{*}$ & $(0.01)$ & $0.02 *$ & $(0.01)$ & $0.02 *$ & $(0.01)$ & 0.01 & (0.009) \\
\hline Flood spill over(Dummy) & $0.02 * *$ & $(0.005)$ & $0.02 * *$ & $(0.005)$ & $0.02 * *$ & $(0.005)$ & $0.01 * * *$ & $(0.004)$ & $0.01 * * *$ & $(0.004)$ & $0.02 * * *$ & $(0.004)$ \\
\hline Self-reported Drought (Dummy) & $0.04^{* * *}$ & $(0.014)$ & $0.04 * *$ & $(0.014)$ & $0.04^{* *}$ & $(0.014)$ & 0.07 & $(0.05)$ & 0.07 & $(0.05)$ & $0.03^{* *}$ & $(0.01)$ \\
\hline Drought spill over (Dummy) & 0.01 & $(0.008)$ & 0.01 & $(0.006)$ & 0.01 & $(0.01)$ & 0.05 & $(0.05)$ & 0.05 & $(0.05)$ & -0.003 & $(0.01)$ \\
\hline Shared Toilet (Dummy) & & & & & $0.02^{* * *}$ & $(0.005)$ & $0.02^{* *}$ & $(0.005)$ & $0.02 * *$ & $(0.005)$ & $0.02^{* *}$ & $(0.01)$ \\
\hline Public Toilet (Dummy) & & & & & $0.04^{* * *}$ & $(0.005)$ & $0.04^{* * *}$ & $(0.004)$ & $0.04^{* * *}$ & $(0.004)$ & $0.04^{* * *}$ & $(0.01)$ \\
\hline Drinking Water well(Dummy) & & & & & $0.02^{* *}$ & $(0.005)$ & $0.01^{* *}$ & (0.005) & $0.01^{* *}$ & (0.005) & $0.01^{* *}$ & $(0.006)$ \\
\hline Drinking water unsafe source(Dummy) & & & & & 0.00 & $(0.006)$ & -0.00 & $(0.006)$ & -0.00 & $(0.04)$ & -0.01 & $(0.01)$ \\
\hline Water reservoirs (\%) & & & & & & & & & & & $0.003 * * *$ & $(0.001)$ \\
\hline Natural water bodies (\%) & & & & & & & & & & & -0.001 & $(0.001)$ \\
\hline Month fixed effects & No & & Yes & & Yes & & Yes & & No & & Yes & \\
\hline District fixed effects & No & & No & & No & & Yes & & Yes & & Yes & \\
\hline District land use(\%) & No & & No & & No & & No & & No & & Yes & \\
\hline Pseudo R2 & 0.03 & & 0.03 & & 0.03 & & 0.04 & & 0.04 & & 0.03 & \\
\hline
\end{tabular}

Notes: Robust standard errors in the bracket. $* * *, * *, *$, stand for significance at $1 \%, 5 \%$ and $10 \%$ respectively. There are 79381 observations.

Structural-demographic covariates included in all specifications are sex, age, years of education, ethnicity, employment status, live in rural sector, live in estate sector, income, time to hospital. Model $(v)$ is used for the cost calculations. To check validity of probit model, we estimated the linear probability model of the same specification and that reveals similar results (Appendix table 2-10). 
Table 2-3 : Health impacts of flood and drought: inpatient health treatment for different groups

\begin{tabular}{|c|c|c|c|c|c|c|c|c|c|c|}
\hline Variables & Rural & & Urban & & Estate & & Young & & Old & \\
\hline Self-reported flood (Dummy) & $0.02^{*}$ & $(0.01)$ & 0.004 & $(0.003)$ & 0 & 0 & 0.01 & (0.01) & $0.03 * * *$ & $(0.01)$ \\
\hline Flood spill over(Dummy) & $0.01 * *$ & $(0.005)$ & 0.004 & $(0.002)$ & $-0.05 *$ & $(0.03)$ & $0.02^{* * *}$ & (0.005) & $0.02 * * *$ & (0.006) \\
\hline Self-reported Drought (Dummy) & 0.07 & $(0.06)$ & $0.02 * *$ & $(0.006)$ & $-0.96 * * *$ & $(0.07)$ & 0.05 & $(0.05)$ & $0.10 *$ & $(0.06)$ \\
\hline Drought spill over (Dummy) & 0.05 & $(0.06)$ & $0.10 * * *$ & $(0.03)$ & $-0.94 * * *$ & $(0.08)$ & 0.04 & $(0.05)$ & 0.08 & $(0.06)$ \\
\hline Shared Toilet (Dummy) & $0.02^{* * *}$ & $(0.005)$ & 0.003 & $(0.002)$ & $0.05^{* * *}$ & $(0.02)$ & $0.02^{* *}$ & (0.006) & $0.02^{* *}$ & $(0.007)$ \\
\hline Public Toilet (Dummy) & $0.04^{* * *}$ & $(0.006)$ & $0.01^{* * *}$ & $(0.003)$ & $0.05^{* *}$ & $(0.02)$ & $0.03^{* * *}$ & $(0.005)$ & $0.05^{* * *}$ & $(0.007)$ \\
\hline Drinking Water well(Dummy) & $0.01^{* *}$ & $(0.005)$ & 0.00 & $(0.001)$ & $0.10 * * *$ & (0.02) & 0.006 & $(0.005)$ & $0.02^{* *}$ & $(0.006)$ \\
\hline Drinking water unsafe source(Dummy) & -0.00 & $(0.007)$ & -0.00 & $(0.001)$ & $0.09 * * *$ & $(0.01)$ & -0.004 & $(0.004)$ & -0.004 & $(0.009)$ \\
\hline Pseudo R2 & 0.05 & & 0.06 & & 0.05 & & 0.04 & & 0.04 & \\
\hline No. of observations & 51364 & & 20451 & & 7514 & & 40300 & & 39081 & \\
\hline
\end{tabular}

Notes: All models estimated in this table include month and district fixed-effects, but not the land use variables. Robust standard errors in the bracket. $* * * * *, *$, stand for significance at $1 \%, 5 \%$ and $10 \%$ respectively. 
Table 2-4: Immediate health effects of flood and drought

\begin{tabular}{|c|c|c|c|c|c|c|c|c|c|c|c|c|}
\hline Variables & (i) & & (ii) & & (iii) & & (iv) & & (v) & & (vi) & \\
\hline $\begin{array}{l}\text { Flood last month } \\
\text { Drought Last month }\end{array}$ & $\begin{array}{l}0.01 \\
0.04 * * *\end{array}$ & $\begin{array}{l}(0.01) \\
(0.01) \\
\end{array}$ & $\begin{array}{l}0.01 \\
0.04 * * * \\
\end{array}$ & $\begin{array}{l}(0.01) \\
(0.01) \\
\end{array}$ & $\begin{array}{l}0.01 \\
0.04 * * * \\
\end{array}$ & $\begin{array}{l}(0.01) \\
(0.01) \\
\end{array}$ & $\begin{array}{l}-0.003 \\
0.02 \\
\end{array}$ & $\begin{array}{l}(0.01) \\
(0.02) \\
\end{array}$ & $\begin{array}{l}0.0003 \\
0.03 * * \\
\end{array}$ & $\begin{array}{l}(0.01) \\
(0.01) \\
\end{array}$ & $\begin{array}{l}-0.002 \\
0.01 \\
\end{array}$ & $\begin{array}{l}(0.01) \\
(0.02) \\
\end{array}$ \\
\hline $\begin{array}{l}\text { Shared Toilet (Dummy) } \\
\text { Public Toilet (Dummy) } \\
\text { Drinking Water well(Dummy) } \\
\text { Drinking water unsafe } \\
\text { source(Dummy) }\end{array}$ & & & & & $\begin{array}{l}0.02 * * \\
0.01 \\
-0.01 \\
-0.01\end{array}$ & $\begin{array}{l}(0.01) \\
(0.01) \\
(0.01) \\
(0.01)\end{array}$ & $\begin{array}{l}0.02 * * \\
0.02 \\
0.003 \\
-0.002\end{array}$ & $\begin{array}{l}(0.01) \\
(0.02) \\
(0.01) \\
(0.01)\end{array}$ & $\begin{array}{l}0.03^{* * *} \\
0.02 \\
0.003 \\
-0.002\end{array}$ & $\begin{array}{l}(0.01) \\
(0.02) \\
(0.01) \\
(0.01)\end{array}$ & $\begin{array}{l}0.02 * * \\
0.01 \\
-0.01 \\
-0.004\end{array}$ & $\begin{array}{l}(0.01) \\
(0.01) \\
(0.01) \\
(0.01)\end{array}$ \\
\hline $\begin{array}{l}\text { Water reservoirs (\%) } \\
\text { Natural water bodies (\%) }\end{array}$ & & & & & & & & & & & $\begin{array}{l}0.01^{* * *} \\
-0.01^{* * *}\end{array}$ & $\begin{array}{l}(0.001) \\
(0.002)\end{array}$ \\
\hline $\begin{array}{l}\text { Month fixed effects } \\
\text { District fixed effects } \\
\text { District Land use (\%) }\end{array}$ & $\begin{array}{l}\text { No } \\
\text { No } \\
\text { No } \\
\end{array}$ & & $\begin{array}{l}\text { Yes } \\
\text { No } \\
\text { No } \\
\end{array}$ & & $\begin{array}{l}\text { Yes } \\
\text { No } \\
\text { No } \\
\end{array}$ & & $\begin{array}{l}\text { Yes } \\
\text { Yes } \\
\text { No } \\
\end{array}$ & & $\begin{array}{l}\text { No } \\
\text { Yes } \\
\text { No } \\
\end{array}$ & & $\begin{array}{l}\text { Yes } \\
\text { No } \\
\text { Yes }\end{array}$ & \\
\hline Pseudo R2 & 0.03 & & 0.04 & & 0.05 & & 0.05 & & 0.05 & & 0.05 & \\
\hline
\end{tabular}

Notes: Robust standard errors in the bracket. ${ }^{* * *},{ }^{* *},{ }^{*}$, stand for significance at $1 \%, 5 \%$ and $10 \%$ respectively. There are 79381 observations.

Structural-demographic covariates include sex, age, years of education, ethnicity, employment status, live in rural sector, estate sector,

income, and time to hospital. Model (v) is used for the cost calculation. To check validity of probit model, we estimated the linear probability model of the same specification and that reveals similar results (Appendix table 2-10). 
Table 2-5 Private healthcare costs (per month, for inpatient and outpatient services)

\begin{tabular}{|c|c|c|c|c|c|c|}
\hline Variables & (i) & & (ii) & & (iii) & \\
\hline Inpatient (At least once last year) & & & $1720.18^{* * *}$ & $(166.9)$ & $1602.2^{* * *}$ & $(17643)$ \\
\hline Outpatient (At least once last month) & $709.3^{* * *}$ & $(111.0)$ & & & $502.4^{* * *}$ & (113.03) \\
\hline male or female (Dummy) & $180.7^{*}$ & (104.1) & $171.33^{*}$ & $(104.03)$ & $169.90^{*}$ & (103.98) \\
\hline Age (Years) & $10.92^{* * *}$ & $(2.55)$ & $10.82^{* * *}$ & $(2.53)$ & $8.471^{* * *}$ & $(2.56)$ \\
\hline Education (Years) & $64.71^{* * *}$ & $(11.42)$ & $58.54^{* * *}$ & $(11.34)$ & $63.16^{* * *}$ & $(11.42)$ \\
\hline Sinhalese (Dummy) & 449.64 & (753.52) & 469.45 & (750.89) & 467.38 & (753.47) \\
\hline Tamil (Dummy) & 227.57 & $(753.58)$ & 170.25 & $(753.20)$ & 543.61 & (760.99) \\
\hline Employed(Dummy) & $-486.24^{* * *}$ & (131.59) & $-509.70^{* * *}$ & (131.13) & $-458.47^{* * *}$ & (131.57) \\
\hline Employer(dummy) & -564.42 & $(607.37)$ & -553.99 & (607.11) & -5484.53 & (606.81) \\
\hline Own family worker(dummy) & $-710.62^{* * *}$ & $(163.47)$ & $-716.05^{* * *}$ & $(163.22)$ & $-546.22^{* * *}$ & (164.44) \\
\hline Rural sector (dummy) & $-290.97^{* *}$ & (121.34) & $-305.15^{* * *}$ & (121.31) & $-179.87^{* * *}$ & (127.30) \\
\hline Estate sector(Dummy) & $-778.76^{* * *}$ & (197.29) & $-755.90^{* * *}$ & (197.15) & $-672.13^{* * *}$ & $(224,02)$ \\
\hline Total income (Rs.) & $0.02^{* * *}$ & $(0.002)$ & $0.02^{* * *}$ & $(0.001)$ & $0.02^{* * *}$ & $(0.001)$ \\
\hline Time to hospital & $-29.9^{* * *}$ & $(7.77)$ & $-30.72^{* * *}$ & $(7.76)$ & -26.81 & $(8.03)$ \\
\hline Constant & 31.31 & (760.31) & 49.19 & (758.89) & -1149.43 & (890.56) \\
\hline Observations & 79381 & & 79381 & & 79381 & \\
\hline$R^{2}$ & 0.005 & & 0.006 & & 0.01 & \\
\hline $\mathrm{F}$ & 32.85 & & 37.32 & & 36.26 & \\
\hline df_m & 13 & & 13 & & 14 & \\
\hline
\end{tabular}

Robust standard errors in parentheses, ${ }^{*} p<0.1,{ }^{* *} p<0.05,{ }^{* * *} p<0.01$ 
Table 2-6 District level population vulnerability to flood and drought related health risk

\begin{tabular}{|c|c|c|c|c|c|c|c|c|c|c|}
\hline \multirow{3}{*}{$\begin{array}{l}\text { Province } \\
\text { Western }\end{array}$} & \multirow[b]{2}{*}{ District } & \multicolumn{5}{|c|}{ Flood associated inpatient care cost/year } & \multicolumn{4}{|c|}{ Drought associated outpatient care cost /month } \\
\hline & & $\begin{array}{l}\text { inpatients if total } \\
\text { population is } \\
\text { directly affected }\end{array}$ & $\begin{array}{l}\text { Public sector } \\
\text { inpatient care } \\
\text { cost (USD) }\end{array}$ & $\begin{array}{l}\text { Private sector } \\
\text { inpatient care } \\
\text { cost (USD) }\end{array}$ & $\begin{array}{l}\text { Inpatients if each } \\
\text { district experiences } \\
\text { flood }\end{array}$ & $\begin{array}{l}\text { Public sector } \\
\text { inpatient care } \\
\text { cost (USD) }\end{array}$ & $\begin{array}{l}\text { Private sector } \\
\text { inpatient care } \\
\text { cost (USD) }\end{array}$ & $\begin{array}{l}\text { Outpatients if total } \\
\text { population is affected } \\
\text { by drought }\end{array}$ & $\begin{array}{l}\text { Public sector } \\
\text { outpatient care } \\
\text { cost (USD) }\end{array}$ & $\begin{array}{l}\text { Private sector } \\
\text { outpatient care } \\
\text { cost (USD) }\end{array}$ \\
\hline & Colombo & 46196 & 956918 & 569277 & 23098 & 478459 & 284638 & 69294 & 148716 & 267581 \\
\hline \multirow{5}{*}{ Central } & Gampaha & 45892 & 353577 & 565531 & 22946 & 176788 & 282765 & 68838 & 54949 & 265821 \\
\hline & Kalutara & 24346 & 471327 & 300018 & 12173 & 235664 & 150009 & 36519 & 73246 & 141020 \\
\hline & Kandy & 27398 & 530413 & 337628 & 13699 & 265206 & 168814 & 41097 & 82428 & 158698 \\
\hline & Matale & 9644 & 99528 & 118844 & 4822 & 49764 & 59422 & 14466 & 15467 & 55861 \\
\hline & Nuwaraeliya & 14132 & 113305 & 174150 & 7066 & 56652 & 87075 & 21198 & 17609 & 81857 \\
\hline \multirow[t]{3}{*}{ Southern } & Galle & 21176 & 326363 & 260953 & 10588 & 163181 & 130477 & 31764 & 50720 & 122658 \\
\hline & Matara & 16186 & 165384 & 199461 & 8093 & 82692 & 99731 & 24279 & 25702 & 93754 \\
\hline & Hambantota & 11932 & 130408 & 147039 & 5966 & 65204 & 73519 & 17898 & 20266 & 69114 \\
\hline \multirow[t]{5}{*}{ Nothern } & Jaffna & 11660 & 188497 & 143687 & 5830 & 94249 & 71844 & 17490 & 29293 & 67538 \\
\hline & Mannar & 1982 & 33728 & 24424 & 991 & 16864 & 12212 & 2973 & 5242 & 11480 \\
\hline & Vavuniya & 3430 & 47298 & 42268 & 1715 & 23649 & 21134 & 5145 & 7351 & 19868 \\
\hline & Mulativu & 1838 & 33815 & 22650 & 919 & 16907 & 11325 & 2757 & 5255 & 10646 \\
\hline & Kilinochchi & 2258 & 20366 & 27826 & 1129 & 10183 & 13913 & 3387 & 3165 & 13079 \\
\hline \multirow[t]{3}{*}{ Eastern } & Batticaloa & 10502 & 148435 & 129417 & 5251 & 74218 & 64708 & 15753 & 23067 & 60831 \\
\hline & Ampara & 12962 & 182688 & 159732 & 6481 & 91344 & 79866 & 19443 & 28391 & 75080 \\
\hline & Trincomalee & 7564 & 80236 & 93212 & 3782 & 40118 & 46606 & 11346 & 12469 & 43813 \\
\hline \multirow[t]{2}{*}{ North western } & Kurunegala & 32206 & 391127 & 396877 & 16103 & 195564 & 198439 & 48309 & 60784 & 186547 \\
\hline & Puttlam & 15196 & 131870 & 187261 & 7598 & 65935 & 93631 & 22794 & 20494 & 88020 \\
\hline \multirow[t]{2}{*}{ North Central } & Anuradhapura & 17124 & 255677 & 211020 & 8562 & 127839 & 105510 & 25686 & 39734 & 99187 \\
\hline & Polonnaruwa & 8066 & 114533 & 99398 & 4033 & 57266 & 49699 & 12099 & 17799 & 46721 \\
\hline \multirow[t]{2}{*}{ Uva } & Badulla & 16236 & 268250 & 200077 & 8118 & 134125 & 100039 & 24354 & 41688 & 94044 \\
\hline & Moneragala & 8962 & 112079 & 110439 & 4481 & 56039 & 55220 & 13443 & 17418 & 51911 \\
\hline \multirow[t]{2}{*}{ Sabaragamuwa } & Ratnapura & 21646 & 251114 & 266745 & 10823 & 125557 & 133373 & 32469 & 39025 & 125380 \\
\hline & Kegalle & 16732 & 171248 & 206190 & 8366 & 85624 & 103095 & 25098 & 26614 & 96917 \\
\hline
\end{tabular}


Table 2-7 Public health cost of flood and drought (USD)

\begin{tabular}{|c|c|c|c|c|c|c|c|c|c|c|c|c|c|}
\hline \multirow[b]{3}{*}{ Province } & \multicolumn{8}{|c|}{ Flood associated inpatient care cost/year } & \multicolumn{4}{|c|}{ Drought associated outpatient care cost /month } & \multirow[t]{3}{*}{$\begin{array}{l}\text { Total } \\
\text { cost per } \\
\text { capita }\end{array}$} \\
\hline & \multicolumn{4}{|c|}{$\begin{array}{l}\text { If the total population in each district is directly affected } \\
\text { by flood }\end{array}$} & \multicolumn{4}{|c|}{ Health spill overs if all districts experience flood } & \multicolumn{4}{|c|}{ If all districts experience drought } & \\
\hline & $\begin{array}{l}\text { Public sector } \\
\text { inpatient } \\
\text { care cost }\end{array}$ & $\begin{array}{l}\text { Private } \\
\text { inpatient } \\
\text { care cost }\end{array}$ & $\begin{array}{l}\text { Private and } \\
\text { public-sector } \\
\text { cost }\end{array}$ & $\begin{array}{l}\text { Per } \\
\text { capita } \\
\text { cost }\end{array}$ & $\begin{array}{l}\text { Public sector } \\
\text { inpatient } \\
\text { care cost }\end{array}$ & $\begin{array}{l}\text { Private } \\
\text { inpatient } \\
\text { care cost }\end{array}$ & $\begin{array}{l}\text { Private and } \\
\text { public- } \\
\text { sector cost }\end{array}$ & $\begin{array}{l}\text { Per } \\
\text { capita } \\
\text { cost } \\
\end{array}$ & $\begin{array}{l}\text { Public sector } \\
\text { outpatient } \\
\text { care cost }\end{array}$ & $\begin{array}{l}\text { Private sector } \\
\text { outpatient } \\
\text { care cost }\end{array}$ & $\begin{array}{l}\text { Private and } \\
\text { public- } \\
\text { sector cost }\end{array}$ & $\begin{array}{l}\text { Per } \\
\text { capita } \\
\text { cost }\end{array}$ & \\
\hline Western & $1,781,822$ & $1,434,825$ & $3,216,647$ & 0.6 & 890,911 & 717,413 & $1,608,324$ & 0.3 & 276,910 & 674,422 & 951,332 & 0.2 & 1.0 \\
\hline Central & 743,245 & 630,621 & $1,373,866$ & 0.5 & 371,623 & 315,311 & 686,933 & 0.3 & 115,504 & 296,416 & 411,920 & 0.2 & 1.0 \\
\hline Southern & 622,154 & 607,454 & $1,229,608$ & 0.5 & 311,077 & 303,727 & 614,804 & 0.2 & 96,688 & 285,526 & 382,214 & 0.2 & 0.9 \\
\hline Northern & 323,704 & 260,855 & 584,559 & 0.6 & 161,852 & 130,427 & 292,280 & 0.3 & 50,305 & 122,612 & 172,917 & 0.2 & 1.0 \\
\hline Eastern & 411,360 & 382,360 & 793,720 & 0.5 & 205,680 & 191,180 & 396,860 & 0.3 & 63,928 & 179,724 & 243,651 & 0.2 & 0.9 \\
\hline North western & 522,997 & 584,138 & $1,107,135$ & 0.5 & 261,498 & 292,069 & 553,568 & 0.2 & 81,277 & 274,567 & 355,844 & 0.2 & 0.9 \\
\hline North Central & 370,210 & 310,418 & 680,628 & 0.5 & 185,105 & 155,209 & 340,314 & 0.3 & 57,533 & 145,908 & 203,441 & 0.2 & 1.0 \\
\hline Uva & 380,329 & 310,517 & 690,846 & 0.5 & 190,164 & 155,258 & 345,423 & 0.3 & 59,106 & 145,955 & 205,061 & 0.2 & 1.0 \\
\hline Sabaragamuwa & 422,362 & 472,935 & 895,297 & 0.5 & 211,181 & 236,468 & 447,648 & 0.2 & 65,639 & 222,297 & 287,936 & 0.2 & 0.8 \\
\hline Total & $5,578,183$ & $4,994,124$ & $10,572,307$ & 0.5 & $2,789,091$ & $2,497,062$ & $5,286,153$ & 0.3 & 866,891 & 234,7425 & $3,214,317$ & 0.2 & 0.9 \\
\hline
\end{tabular}

Note: Currency conversion is $1 \mathrm{USD}=130 \mathrm{n}$ Sri Lanka rupees which is as of the exchange rate in 2013. 
Figure 2-1 Interaction effect of flood and drought on seeking inpatient health care

Flood Self-reported*toilet share
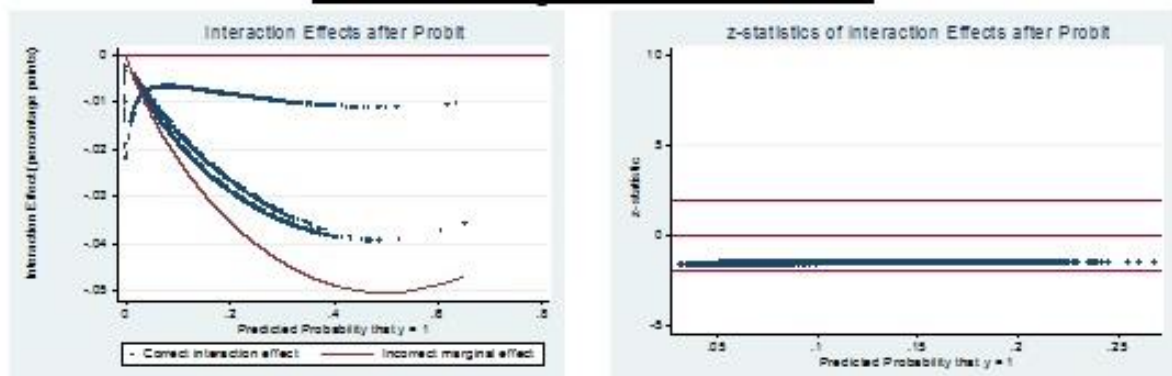

Flood_Self-reported *toilet_public
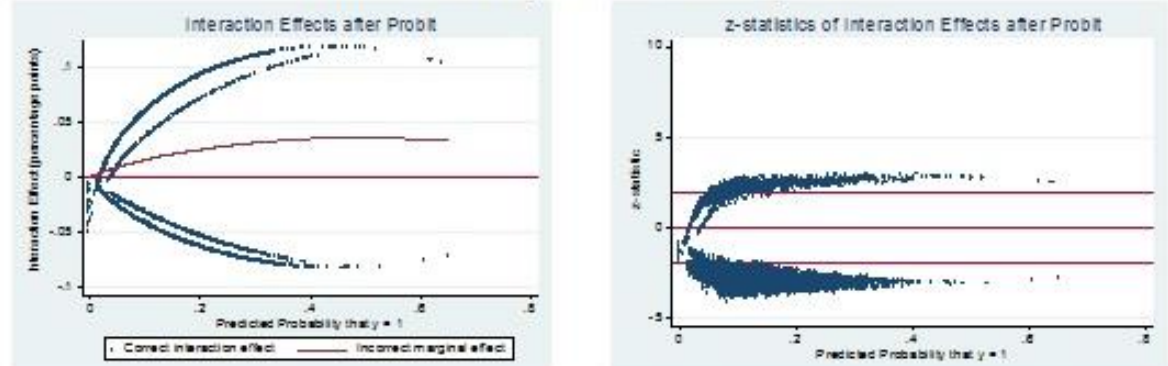

Flood_Self-reported *Drinking Water_unsafe interaction Emects a ter proon
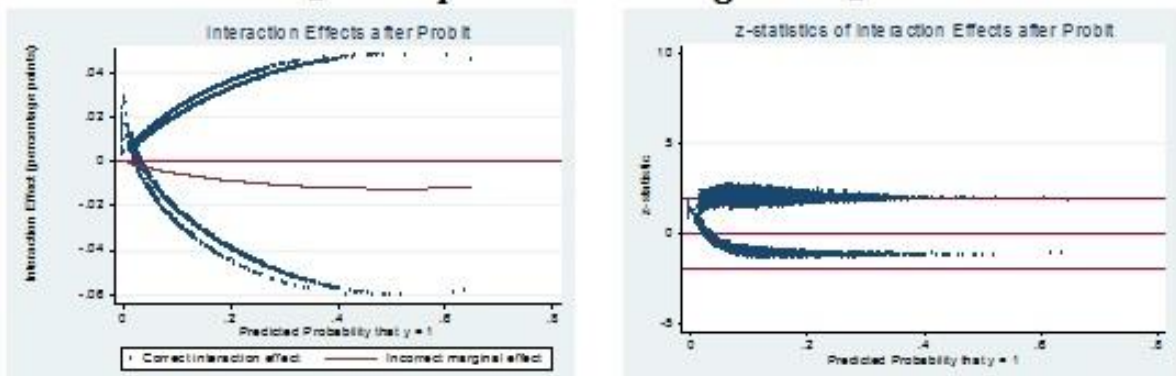

Flood_Spillover *toilet_share
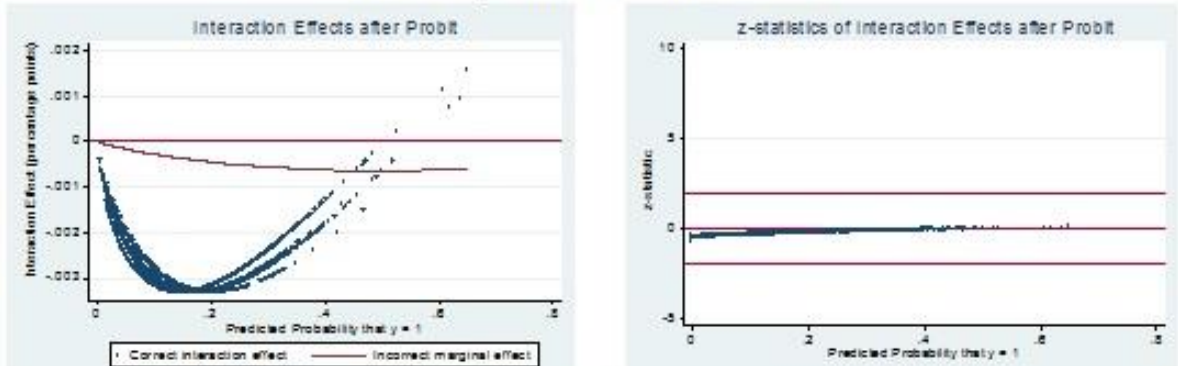


\section{Flood_Self-reported *Drinking Water_Well}

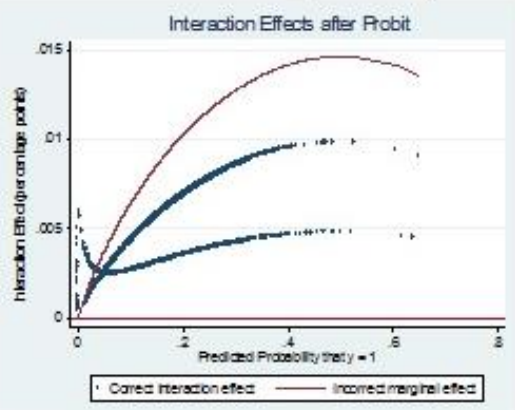

Flood_Spillover *DrinkingWater_Well

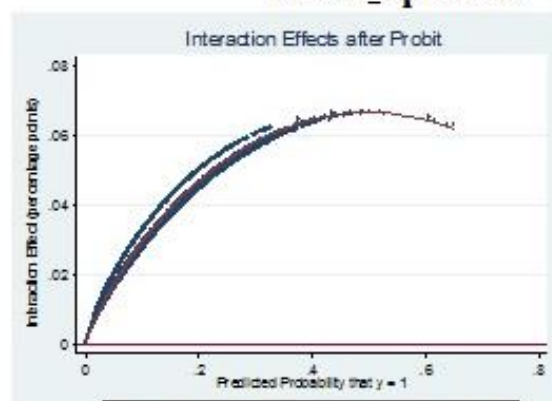

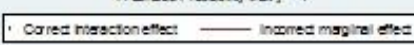
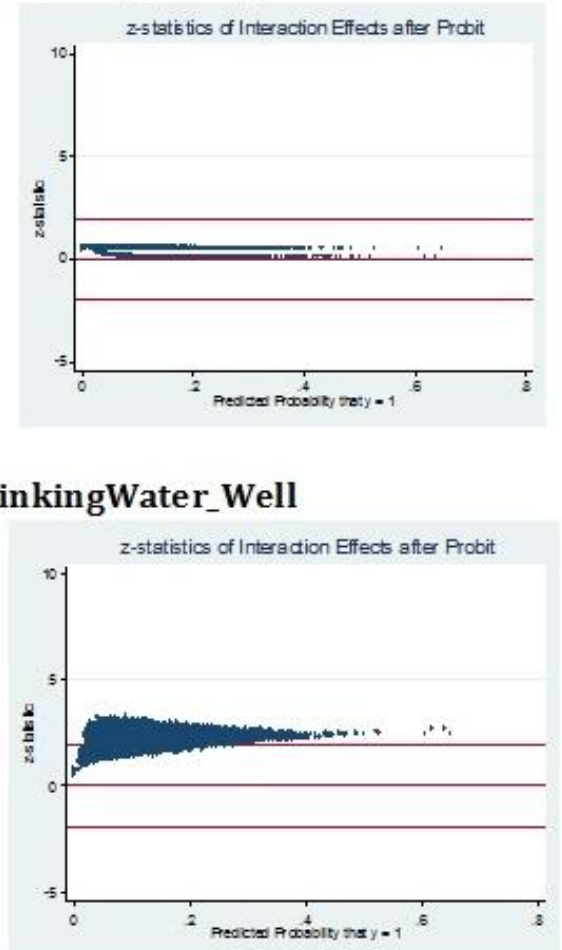

\section{Flood_Spillover *toilet_public}
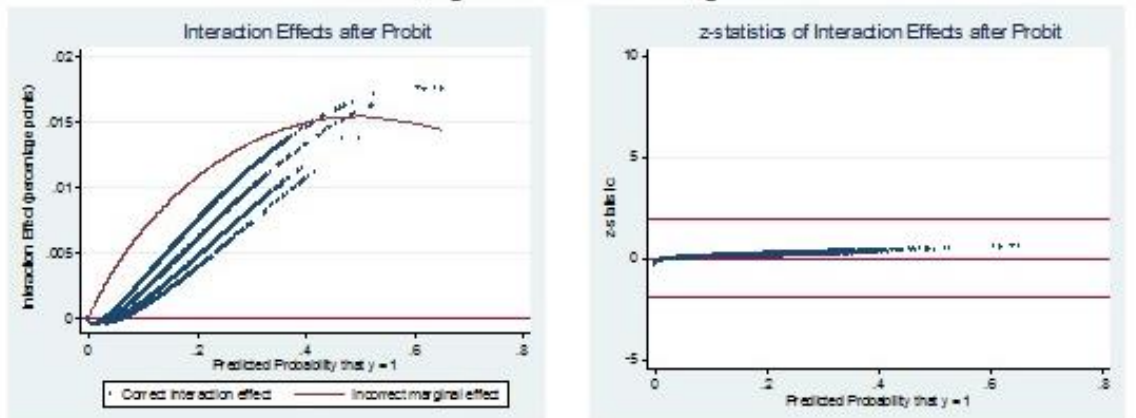

Drought_Self-reported *toilet_public
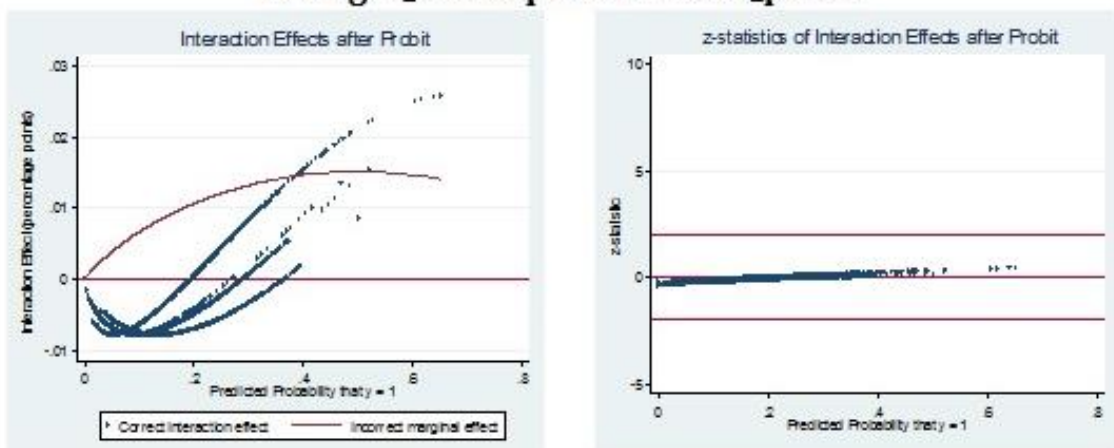
Drought_Spillover *toilet_share

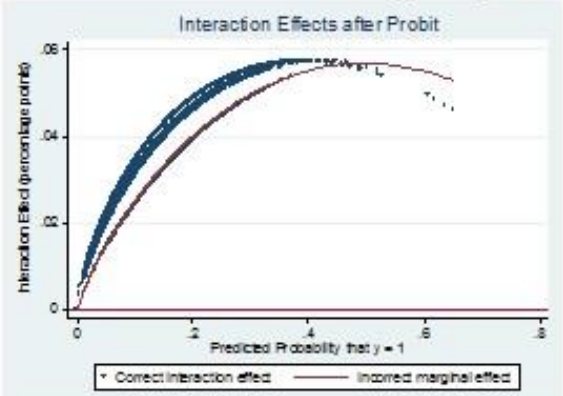

Drought_Spillover *toilet_public

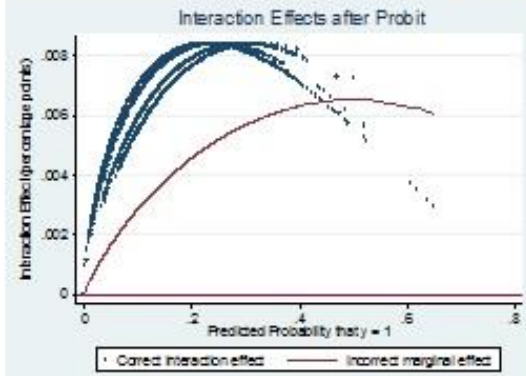

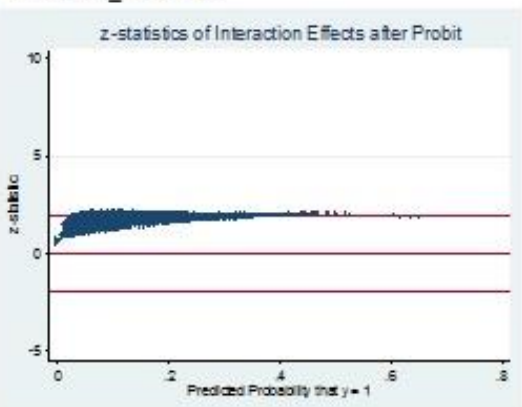

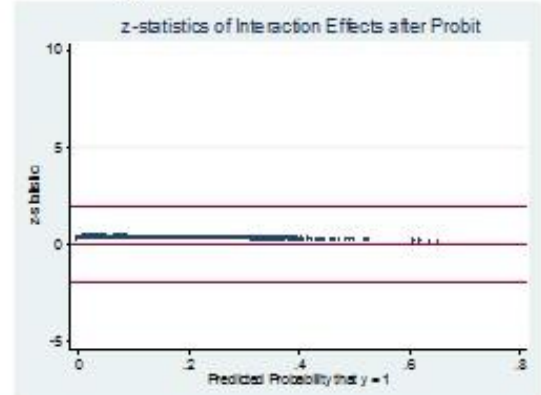

Drought_Spillover *Drinking Water_unsafe
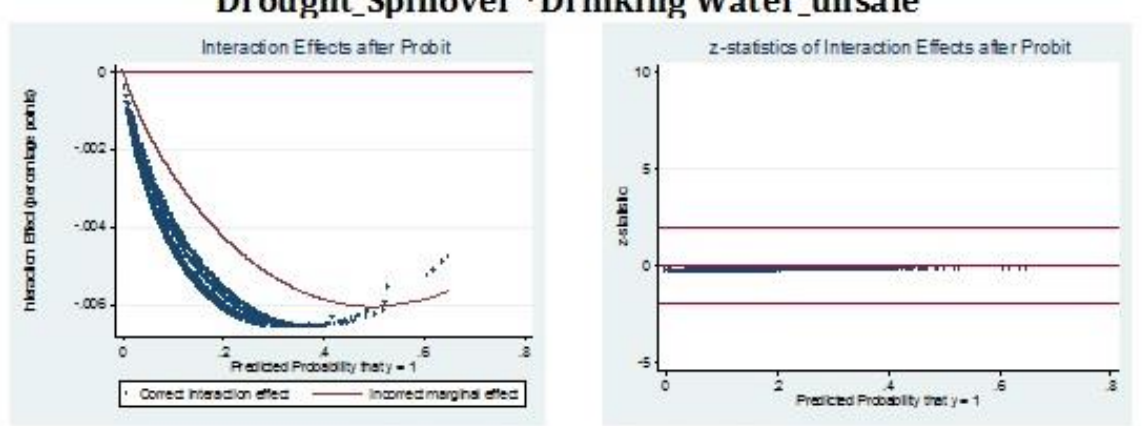

Flood_Self-reported ${ }^{*}$ Rural
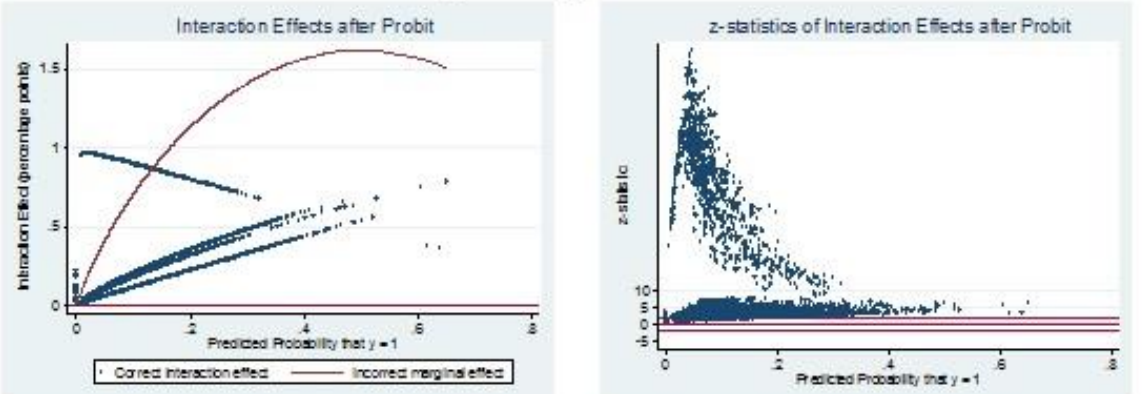


\section{Drought_Spillover *Drinking Water_Well}
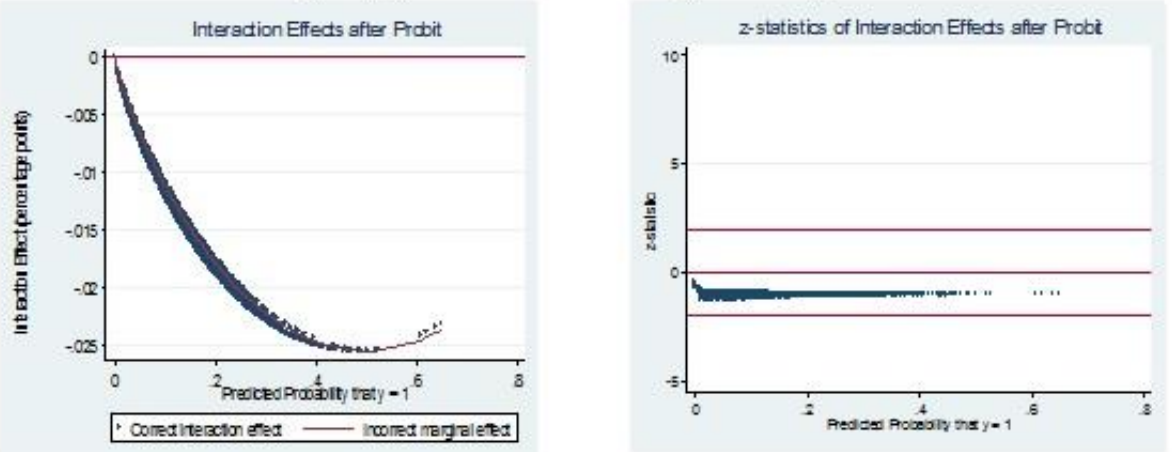

Flood_Spillover *Rural
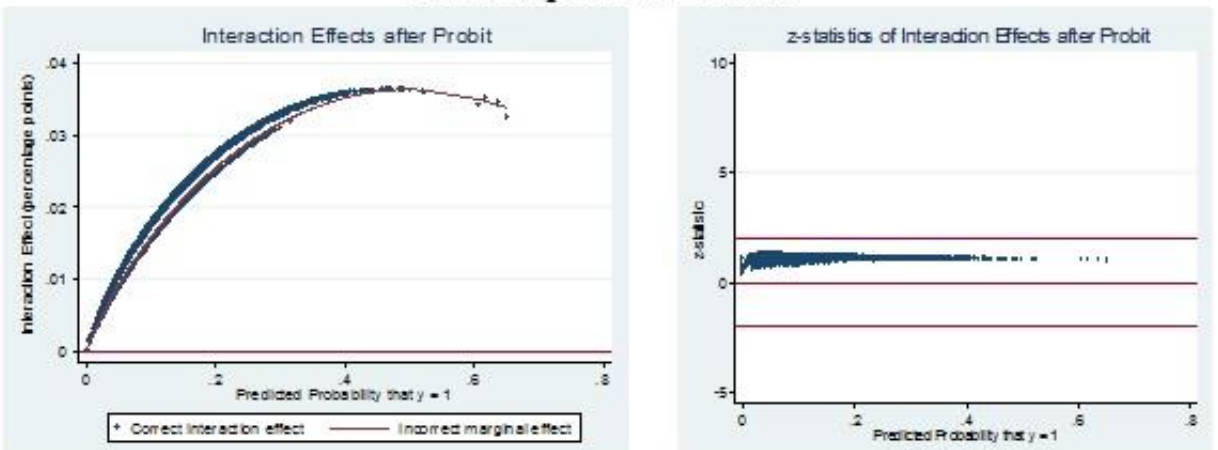

\section{Flood_Self-reported *Urban}
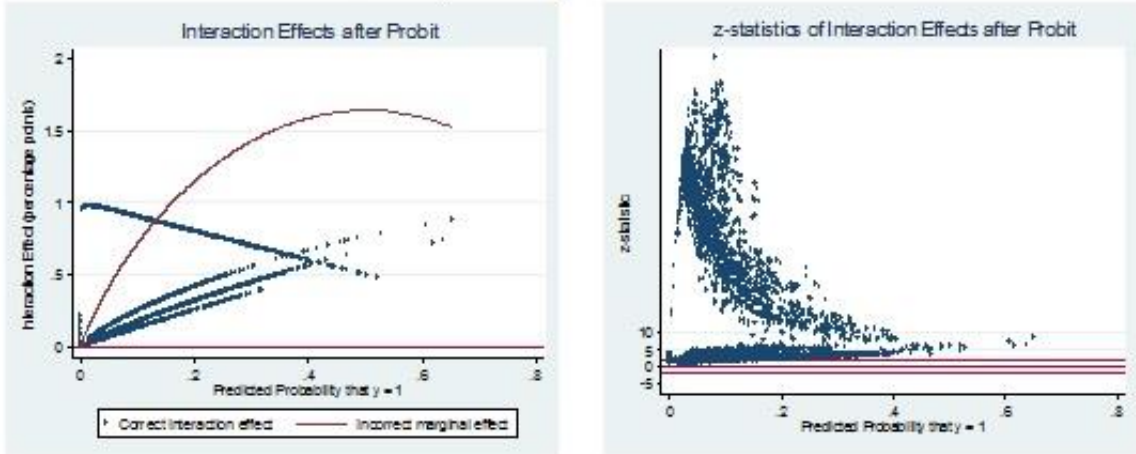

\section{Drought_Self-reported *Urban}

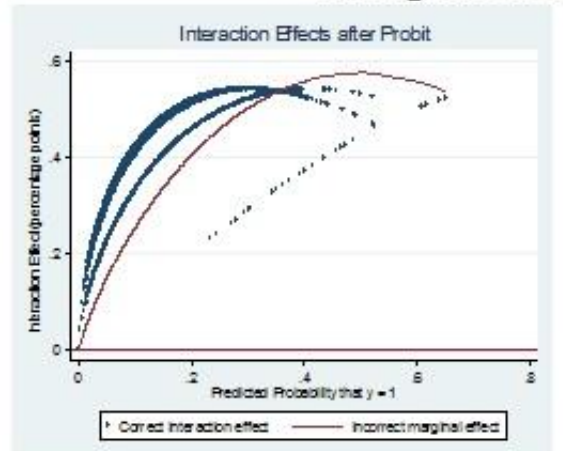

$z$-s tatis tics of Interaction Effect after Probit

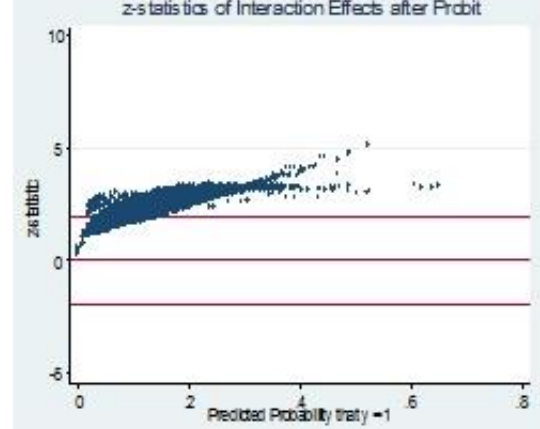




\section{Flood_Spillover *Urban}

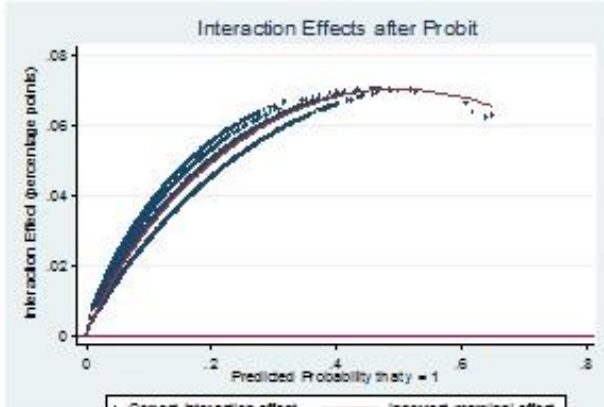

Drought_Self-reported ${ }^{*}$ Rural

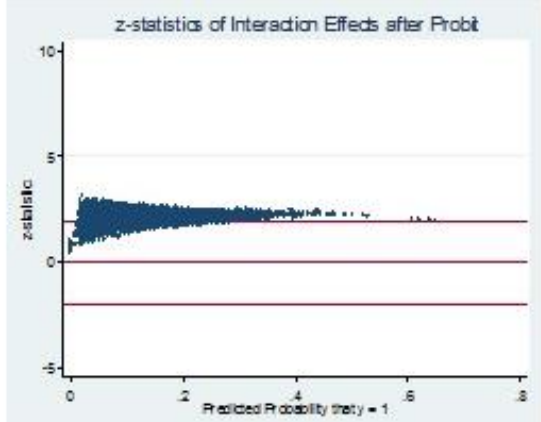

Interaction Effects after Probit

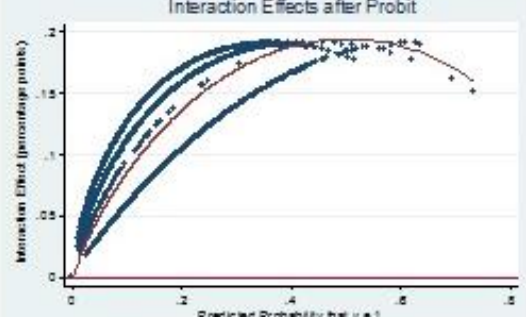

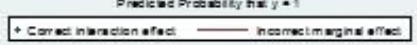

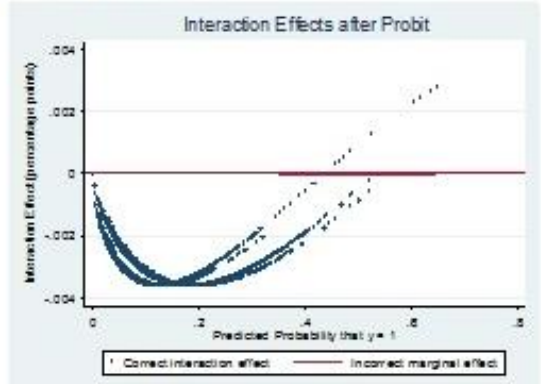

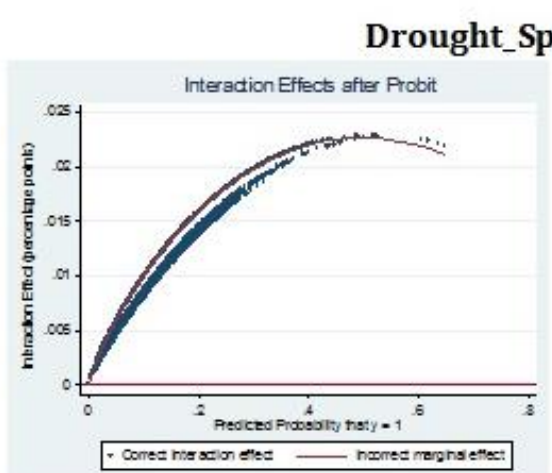

\section{Drought_Spillover *Urban}
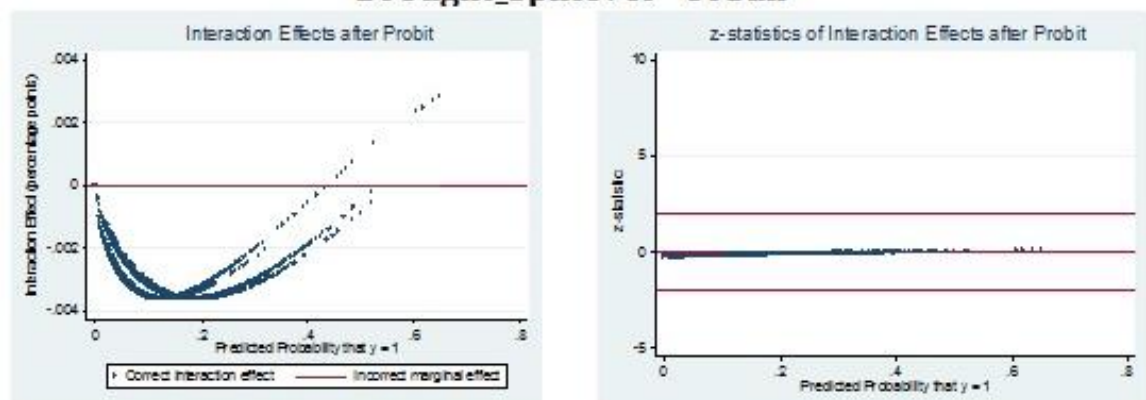
Flood_Self-reported*Aric_water retention Area
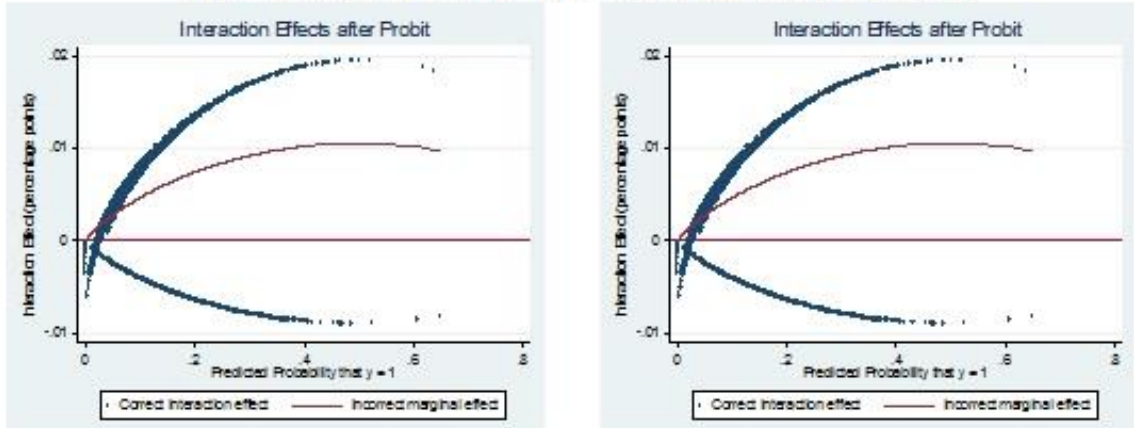

Flood_Spillover* Aric_water retention area
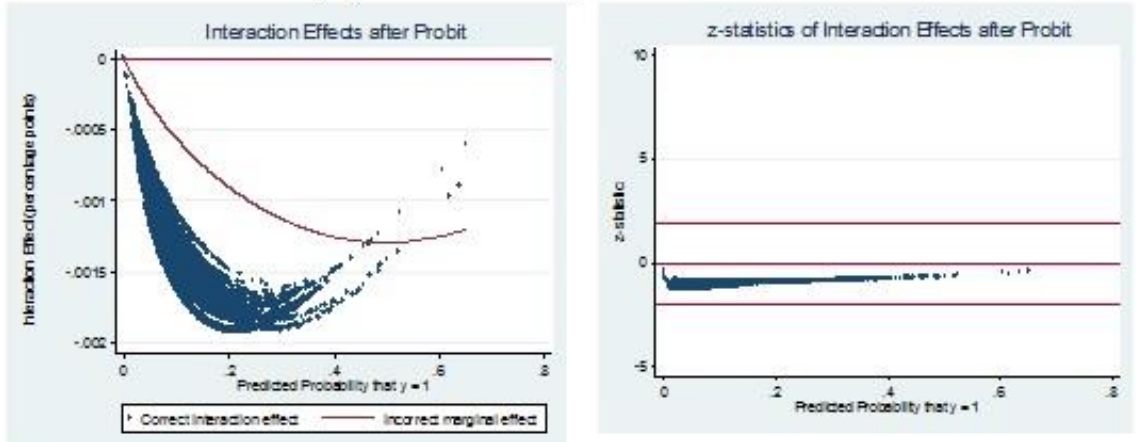

Flood_Self-reported* Lager water retention Area
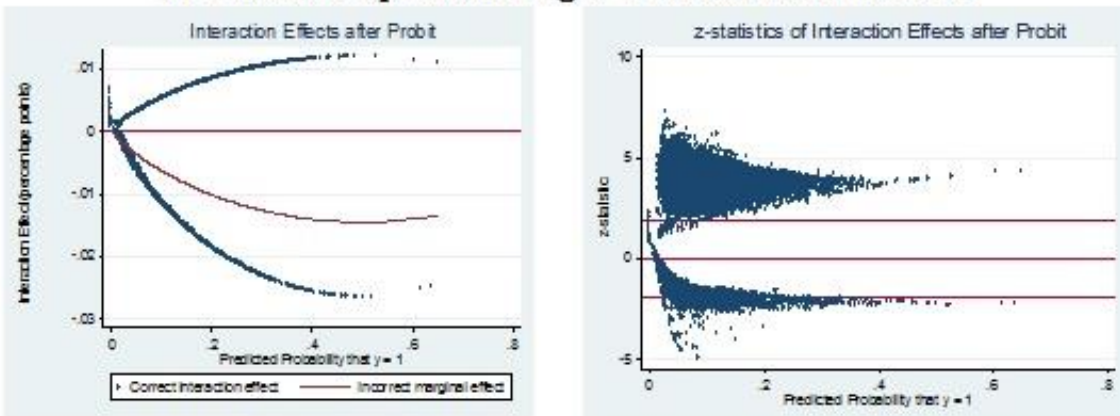

Flood_Spillover* Lager water retention Area
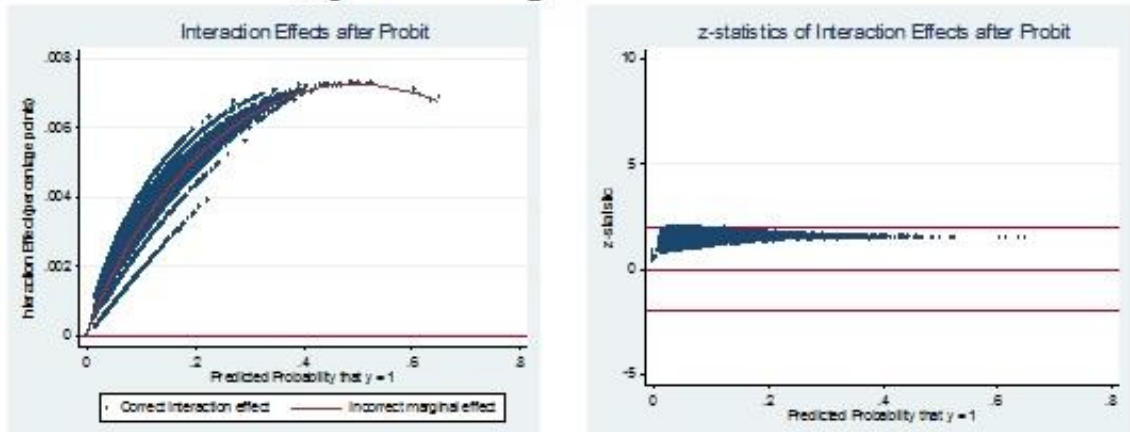


\section{DroughtSelf-reported* Lager water retention Area}

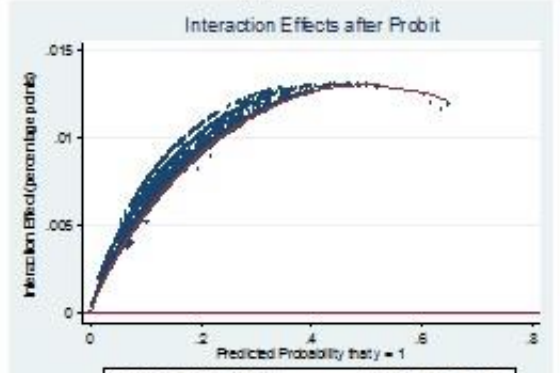

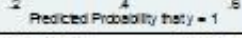

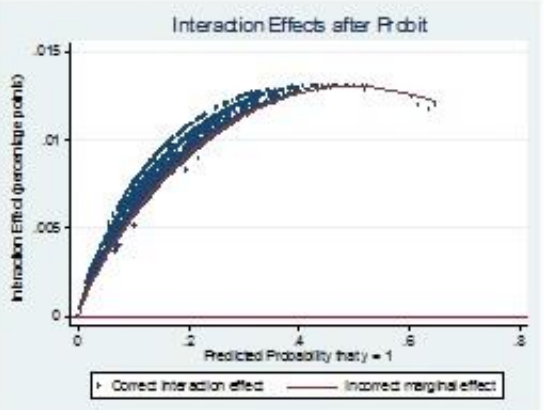

Drought Spillover*Aric_water retention area

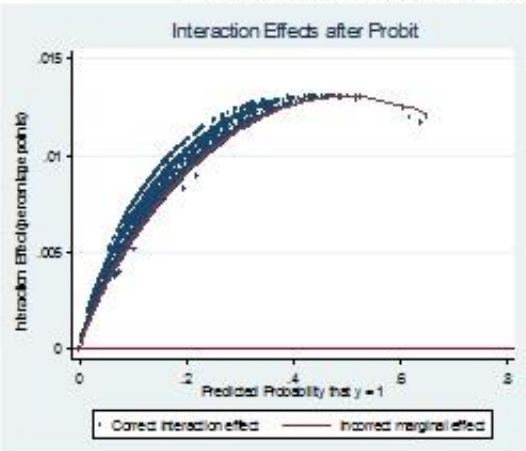

$z$-statistics of Interaction Effeds after Probit

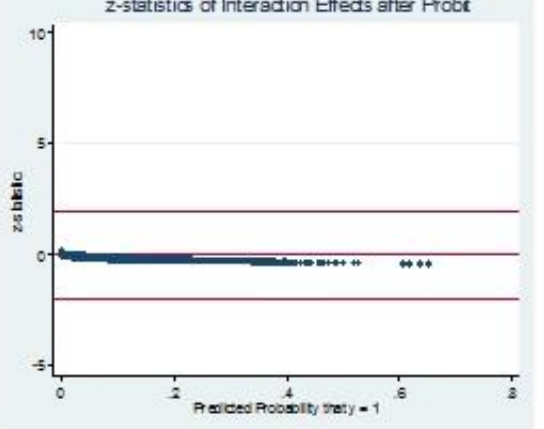

DroughtSelf-reported* Lager water retention Area
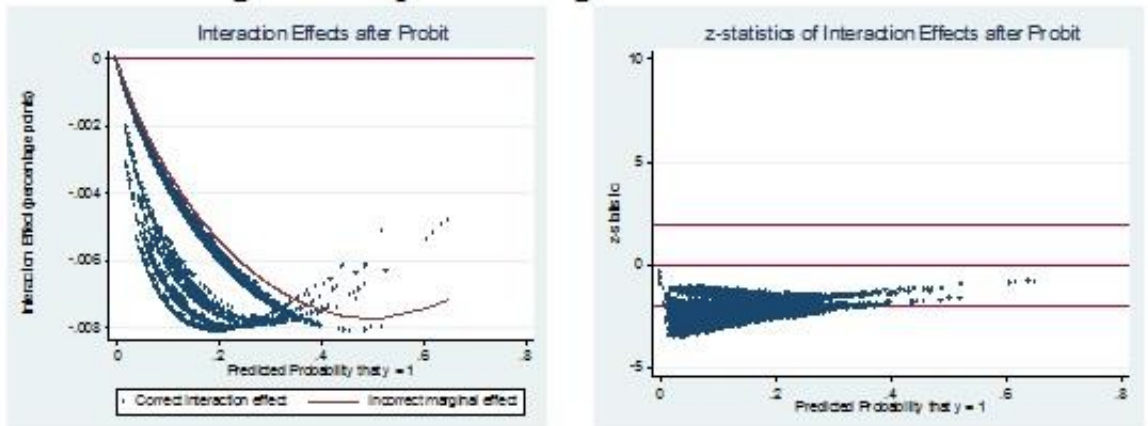

Drought_Spillover* Lager water retention Area

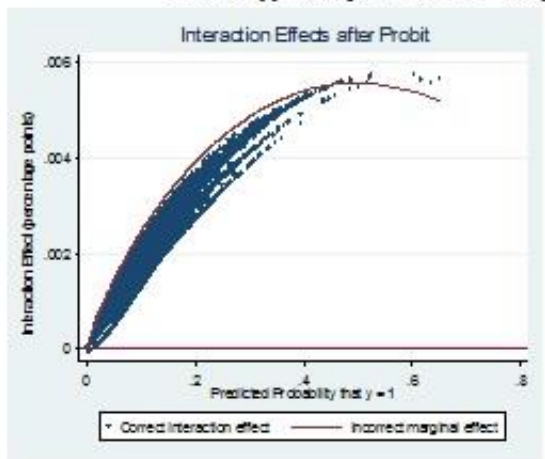




\subsection{References}

Ammed, M. \& Suphachalasai, S. (2014). Assessing the cost of climate change adaptation in South Asia. Mandaluyong City, Philippines: Asian Development Bank.

Agrawala, S., Bosello, F., Carraro, C., \& De Cian, E. (2009). Adaptation, mitigation and innovation: A comprehensive approach to climate policy (Department of Economics, University of Venice Working Paper No 25).

Asian Development Bank. (2011). Accounting for health impacts of climate change. Mandaluyong City, Philippines: Asian Development Bank.

Asian Development Bank. (2014). Economic costs of inadequate water and sanitation: South Tarawa, Kiribati. Mandaluyong City, Philippines: Asian Development Bank.

Berazneva, J. \& Byker, T. S. (2017). Does forest loss increase human disease? Evidence from Nigeria. American Economic Review, 107(5): 516-521.

Bleakley, H. (2010) Malaria eradication in the Americas: A retrospective analysis of Childhood Exposure. American Economic Journal: Applied Economics, 2(2), 1-45.

Bosello F., Roson, \& Tol, R. S, J. (2006) Economy-wide estimates of the implications of climate change: human health. Ecological Economics, 58, 579-81.

Cheong, Y. L., Leitão P. J., \& Lakes, T. (2016). Assessment of land use factors associated with dengue cases in Malaysia using boosted regression Trees. Spatial and Spatiotemporal Epidemiology, 10, 75-84.

Chima, R. I., Goodman, C. A., \& Mills, A. (2003). The economic impact of malaria in Africa: a critical review of the evidence. Health Policy, 63(1):17-36.

Cook, A., Watson, J., Buynder, P. V., Robertsonc, A. \& Weinstein, P. (2008). 10th Anniversary review: Natural disasters and their long-term impacts on the health of communities. J. Environ. Monit., 10, 167-175.

De Alwis, D., \& Noy, I. (2016). Sri Lankan households a decade after the Indian Ocean tsunami (CESifo Working Paper Series No. 6136).

Del, M, Jones, B. \& Olken, B. (2014). What do we learn from the weather? The new climate economy literature. Journal of Economic Literature, 52(3), 740-798.

Department of Census and Statistics. (2014). National survey of self-reported health in Sri Lanka 2014.

Department of Meteorology. (2015). Retrieved from http://www.meteo.gov.lk/ 
Diboulo, E., Sie, A., Rocklov, J., Niamba, L., Ye, M., Bagagnan, C., \& Sauerborn, R. (2012). Weather and mortality: a 10-year retrospective analysis of the Nouna Health and Demographic Surveillance System, Burkina Faso. Global Health Action, 5(Suppl. 1), 19078.

Disaster Management Centre, Ministry of Disaster Management and Human Rights. (2010). Sri Lanka national report on disaster risk: Poverty and human development relationship.

Ebi, K. (2008). Adaptation costs for climate change related cases of diarrhoeal disease, malnutrition, and malaria in 2013. Global Health, 4(1).

Eisenberg, J., Desai, M., Levy, K., Bates, S. J., Liang, S., Naumoff, K. (2007). Environmental determinants of infectious disease: a framework for tracking causal links and guiding public health research. Environ Health Prospect, 115, 1216-1223.

Elsner, J., J. Kossin, and T. Jagger (2008). The Increasing Intensity of the Strongest Tropical Cyclones. Nature 455, pp.92-95.

Emanuel, K. (2005). Increasing destructiveness of tropical cyclones over the past 30 years. Nature 436(7051), 686-688.

Guiteras, R. P., Jina, A. S., \& Mobarak, A. M. (2015). Satellites, Self-reports, and Submersion: Exposure to Floods in Bangladesh. American Economic Review: Papers and Proceedings 105(5): 232-36.

Goossens, L. M., Standaert, B., Hartwig, N., Hövels, A. M., \& Al, M. J. (2008). The costutility of rotavirus vaccination with Rotarix ${ }^{\mathrm{TM}}$ (RIX4414) in the Netherlands. Vaccine, 26 (11), 18-27.

Heutel G., Nolan H. Miller, and Molitor, D. (2017). Adaptation and the Mortality Effects of Temperature Across U.S. Climate Regions. NBER Working Paper No. 23271.

Hoetker, Glenn (2007). The Use of Logit and Probit Models in Strategic Management Research: Critical Issues. Strategic Management Journal 28: 331-343.

Hondula, D. M., Rocklo, J. \& Sankoh, O. A. (2012). Past, present, and future climate at select INDEPTH member health and demographic surveillance systems in Africa and Asia. Glob Health Action 2012, 5, 19083.

Hutton, G. (2008). Economic evaluation of environmental health interventions to support decision making. Environ Health Insights, 2, 137-55.

Institute for Health Policy, Sri Lanka. (2015). Sri Lanka health accounts: national health expenditure 1990-2014. IHP health expenditure series, 4. 
International Monitory Fund. (2017). IMF data mapper. Retrieved from http://www.imf.org/external/datamapper/PPPPC@WE0/OEMDC/ADVEC/WEO WORLD/LKA

IPCC, (2014). Climate change 2014: Impacts, adaptation, and vulnerability. Part A: Global and sectoral aspects. Contribution of Working Group II to the Fifth Assessment Report of the Intergovernmental Panel on Climate Change [Field, C.B., V.R. Barros, D.J. Dokken, K.J. Mach, M.D. Mastrandrea, T.E. Bilir, M. Chatterjee, K.L. Ebi, Y.O. Estrada, R.C. Genova, B. Girma, E.S. Kissel, A.N. Levy, S. MacCracken, P.R. Mastrandrea, and L.L. White (eds.)]. Cambridge, United Kingdom: Cambridge University Press.

Keogh-Brown M. R., \& Smith R. D. (2008). The economic impact of SARS: how does the reality match the predictions?. Health Policy, 88, 110-20.

Knowlton, K., Rotkin-Ellman, M., Geballe, L., Max, W., \& Solomon, G. M. (2011). Six climate change-related events in the United States accounted for about \$14 Billion in lost lives and health costs. Health Affairs, 30(11), 2167-2176.

Kovats, S., Lloyd, S., \& Watkiss, P. (2011). The impacts and socio economic cost on health in Europe and the costs and benefits of adaptation. Technical policy briefing Note 5. Results of EC RTD Climate Cost project. In: Watkiss, P. (Eds.). The climate cost project. Final report Volume1: Europe. Sweden: Stockholm Environment Institute.

Kweka, E. J., Kimaro, E. E. \& Munga, S. (2016). Effect of deforestation and land-use Changes on mosquito productivity and development in western Kenya highlands: Implication for malaria risk. Front Public Health 4: 238.

Lohmann, S. \& Lechtenfeld, T. (2015). The effect of drought on health outcomes and health expenditures in rural Vietnam. World development, 72, 432-448.

Malaney, P. I. A., Spielman, A., \& Sachs, J. (2004). The intolerable burden of malaria II: What's new, what's Needed?. Supplement to American Journal of Tropical Medicine and Hygiene, 71(2).

Malik, A. Yasar, A. Tabinda, A. B. \& Abubakar, M. (2012). Water-borne diseases, Cost of illness and willingness to pay for diseases interventions in rural communities of developing countries. Iranian J Publ Health, 41 (6), 39-49.

McFarlane, R. A., Sleigh, A. C. \& McMichael, A. J. (2013). Land-use change and emerging infectious disease on an island continent. Int. J. Environ. Res. Public Health, 10, 2699-2719.

Melliez, H., Levybruhl, D., Boelle, P. Y., Dervaux, B., Baron, S., \& Yazdanpanah, Y. (2008). Cost and cost-effectiveness of childhood vaccination against rotavirus in France. Vaccine, 26, 706-15.

Merson, M., Black, R. E., \& Mills, A. (2006). International public health: Diseases, programs, systems and policies. USA: Michael Brown. 
Mills, A., \& Shillcutt, S. (2004). The challenge of communicable disease. In Lomborg B. (Eds.), Global crises, Global solutions. Cambridge, UK: Cambridge University Press.

Ministry of Environment, Sri Lanka. (2010). Sector vulnerability profile: Water. Supplementary document to the climate change adaptation strategy.

Ministry of Health, Sri Lanka (2012a). Annual Health Bulletin.

Ministry of Health, Sri Lanka (2012b). Annual epidemiological bulletin.

Ministry of Health, Sri Lanka (2013). Annual Health Bulletin.

Nomura, s., Parson, A. J. Q., Hirabayashi, M., Kinoshita, R., Liao, Y., \& Hodgson, S. (2016). Social determinants of mid-to long term disaster impacts on health: A systemic review. International Journal of Disaster Risk reduction, 16, 53-67.

Philipsborn, R., Ahmed, S. M., Brosi, B. J., \& Levy, K. (2016). Climatic Drivers of Diarrheagenic Escherichia coli Incidence: A systematic review and meta-analysis. $J$ Infect Dis., 214 (1), 6-15.

Sankoh, O. \& Byass, P. (2012). The INDEPTH network: filling vital gaps in global epidemiology. International Journal of Epidemiology, 41(3), 579-588.

Smith, K.R., A. Woodward, D. Campbell-Lendrum, D.D. Chadee, Y. Honda, Q. Liu, J.M. Olwoch, B. Revich, and R. Sauerborn .(2014). Human health: impacts, adaptation, and co-benefits. In: Climate change 2014: Impacts, adaptation, and vulnerability. Part A: Global and sectoral aspects. Contribution of Working Group II to the Fifth Assessment Report of the Intergovernmental Panel on Climate Change [Field, C.B., V.R. Barros, D.J. Dokken, K.J. Mach, M.D. Mastrandrea, T.E. Bilir, M. Chatterjee, K.L. Ebi, Y. O. Estrada, R.C. Genova, B. Girma, E.S. Kissel, A.N. Levy, S. MacCracken, P .R. Mastrandrea, and L.L. White (eds.)]. United Kingdom: Cambridge University Press.

Smith, R. D., Keogh-Brown, M. R., Barnett, T., \& Tait, J. (2009). The economy-wide impact of pandemic influenza on the UK: a computable general equilibrium modelling experiment. British Medical Journal, 339: b 4571.

Sri Lanka Dengue Control Unit. (2017 May 27). Retrieved from http://203.143.20.230/dengue.health.gov.lk/public_html/

Sutherst, R. W. (2004). Global change and human vulnerability to vector-borne diseases. Clinical Microbiology Review, 17(1), 136-173.

The World Bank. (2015). World data bank. Retrieved from http://databank.worldbank.org/data/home.aspx 
UNISDR (2011). 2011 Global Assessment report on disaster risk reduction: Revealing risk, redefining development. Geneva, Switzerland: United Nations Office for Disaster Risk Reduction.

United Nations, Sri Lanka. (2015). Millennium development goals country report.

World Health Organization regional office for Europe. (2013). Climate change and health: A tool to estimate health and adaptation cost. Retrieved from http://www.euro.who.int/_data/assets/pdf_file/0018/190404/WHO_Content_Cl imate_change_health_DruckIII.pdf?ua=1

World Health Organization. (2015). WHO Sri Lanka Annual Report.

World Bank. 2010. The economics of adaptation to climate change: Synthesis report. Washington, DC: World Bank.

World Data Atlas. Retrieved from https://knoema.com/atlas/Sri-Lanka/topics/LandUse/Area/Inland-water 


\subsection{Appendices}

\section{Appendix 2-1: Epidemiological Literature on the links between disasters and diseases}

Direct and Indirect pathways to flood and drought related health effects

Flood and drought can affect human health directly and through indirect pathways. Flood-related direct pathways include deaths and injuries due to drowning, and including profound effects on mental health (Knowlton et al., 2011; Paranjothy et al., 2011, Milojevic et al., 2012). Droughts and extreme heat increase hospital admissions due to cardiovascular, respiratory and kidney diseases (Hansen et al., 2008; Knowlton et al., 2009; Lin and Chan, 2009; Zanobetti et al., 2012) and those correlate with the intensity and duration of the heat (Nitscheke et al., 2011).

Flood and drought also cause infectious diseases indirectly. Both socio economic and ecologic processes mediate the nature and impact of water-related diseases (Eisenberg, et al. 2007;). The infectious disease agent is mostly a microbe - bacteria, virus, fungi, and protozoa- found in its natural reservoirs: humans, animals, and the environment. Both the infectious agent and its vector agents can typically survive within a narrow range of climatic conditions and their growth and survival is sensitive to precipitation level, elevation, wind, and temperature in their incubation period. Heavy rain and flood can affect water-born infectious diseases through the pollution of water with infectious agents. Rain or flood can transport human and animal faecal matter and waste into watersheds contaminating the ground water and surface waterbodies (Carlton et al, 2016; Bhavnani et al, 2014). Inundation or disruption of water services, such as damaged or overwhelmed sewerage or drainage systems, provide ideal conditions for proliferation of disease vectors. Ecological disturbances after rain fall can increase larval habitat and vector population size (e.g., mosquitos, rats) by creating new habitats, or due to abundance of food for the vector after the flood (Ahern et al, 2005). Extreme rainfall events can also synchronize vector host seeking (Gubler et al, 2001). 
Maybe paradoxically and like floods, drought can also increase vector borne diseases such as malaria, leptospirosis, chikungunya, tick-borne fever and other infectious diseases such as diarrhoea, cholera, coccidioidomycosis (valley fever), and flu like symptoms (Stanke et al, 2013, Brown, Medlock, and Murray, 2014). Drought can change key vector habitats by concentrating water into small pools. Drought can severely reduce or eliminate predators and competitors (drought eliminate predators in natural wetlands) and bring mosquitoes and vertebrate hosts into increasing contact with humans. Furthermore, human adaptations to drought risk-such as provision of water storage containers in urban environments and changes in land use-can all play a role in increasing the risk of future vector-borne diseases.

Our understanding of the health outcomes and diseases related to climate change and land use change is more limited. The association of ecological change with increased prevalence of infectious diseases such avian influenza, hanta virus, haemorrhagic fever, Lyme disease, diarrhoeal diseases, has been hypothesized and investigated in several studies (McFarlane, Sleigh, and McMichael, 2013). Sharma (2012), for example, discuss the potential influence of land use on climate induced extreme events and the associated health impacts in the Hindu Kush-Himalayan Region.

\section{Water borne diseases associated with flood and drought}

Diarrheal outbreak were reported due to floods in Mozambique in 2000 (Kondo et al, 2002), Bangladesh in 2004 (Qadri, Khan and Furuque, 2005), Indonesia in 2001-2003 (Vollaard et al,. 2004), and Cambodia (Davies et al, 2015). Cholera epidemics within 25 miles of river systems and characterized by sporadic outbreaks are also more frequent during episodes of prevailing warm temperatures with low river flows (Julta et al, 2013). Increased typhoid cases during high rainfall and high temperature were reported in Kathmandu (ADB, 2011).

Viruses, protozoa, and bacteria can pollute both groundwater and surface water during droughts (Stanke et al., 2013). People who rely on private wells and open water sources such as streams may therefore be at risk from drought-related infectious diseases. Other groups also at increased risk include those who have underlying chronic conditions. 
People are also at risk of bacterial infections (E. coli and Salmonella), acute respiratory and gastrointestinal illnesses and other infectious diseases (typhoid, paratyphoid fever, infectious hepatitis, gastroenteritis, measles, Neisseria meningitides) due to contamination of water, soil, food and sanitation systems that result from floods or droughts.

Vector borne diseases associated with flood and drought

The IPCC (2014) reported malaria, dengue, tick-borne encephalitis, Lyme, Haemorrhagic fever with renal syndrome (HFRS) and plague as the most commonly observed vector borne diseases connected to climatic drivers. Malaria, Dengue, HFRS and plague are associated with precipitation. Malaria is caused by five species of plasmodium parasite that are transmitted by two species of mosquitoes. Precipitation and temperature influence malarial transmission in varying degrees in different locations (Kelly-Hope et al, 2009; Pascual et al, 2006; Lunde et al, 2013). Dengue is viral, and spread by a mosquito (Hi, Zhu, Ng, Ng and Rocklov, 2012; Bhatt et al, 2013). The disease is very prevalent globally, with 96 million infections in 2010 (Bhatt et al, 2013). It also highly correlates with rain, temperature, and humidity ( $\mathrm{Wu}$ et al, 2011, Bhatt et al, 2013), urban environments (Wu et al, 2009) and is inversely associate with wind (Lu et al, 2009). Constructed areas, shrubs, wet grassland, water bodies, and paddy fields, are identified as key land cover types at risk (Sarfraz et al, 2012; Lai, Tao, Xu, 2013). Sri Lanka has been experiencing dengue outbreaks of varying magnitude since 1960 with a large outbreak in 2009 and 2010 (Sirisena and Noordeen, 2016).

Leptospirosis is a bacterial disease transmitted through water, food and soil containing contaminated urine (Leptospirosis) from infected animals. Leptospirosis outbreak were reported due to flood in India in 2000 (Karande et al, 2003), Thailand in 2000 (WHO) and Taiwan and China (Kondo, Seo, Yasuda, 2002) after a Typhoon in 2001. The ecology of leptospirosis is possibly driven by more intensive farming systems and subtle climate change (Heuer et al, 2012). During the last 6 years, an average of more than 5000 cases annually were reported in Sri Lanka (Sirisena and Noordeen, 2016). Outbreaks are usually associated with the wet zones, but an outbreak occurred in a dry zone in 2011 after flooding (Agampodi et al, 2014). 


\section{Other Seasonal disease outbreaks}

Influenza, a viral respiratory illness, is typically associated with seasonal epidemics occurring mainly during winter in temperate countries, but occurring throughout the year in tropical regions, though with unknown prevalence (Cox, 2014). Influenza-like epidemics or acute respiratory infections may increase due to overcrowding, poor ventilation, poor nutrition, and overcrowded in emergency shelters. Outbreaks were reported after the 2005 Pakistan earthquake (WHO, 2006) and after the 2004 tsunami (WHO, 2005). A study in Vietnam finds higher absolute humidity associated with increased influenza-like illness (Thai et al, 2015).

\section{References}

Agampodi, S. B., Dahanayaka, N. J., Bandaranayaka, A. K., Perera, M., ...... Priyankara, S., et al. (2014) Regional differences of Leptospirosis in Sri Lanka: Observations from a flood-associated outbreak in 2011. PLoS Negl Trop Dis, 8(1), e2626.

Ahern, M., Kovats, R. S., Wilkinson, P., Few, R. \& Matthies, F. (2005). Global health impacts of floods: epidemiologic evidence, Epidemiol. Rev., 27, 36-46.

Asian Development Bank. (2011). Accounting for health impacts of climate change. Mandaluyong City, Philippines: Asian Development Bank.

Bhatt, S., Gething, P. W., Brady, O. J., Messina, J. P., Farlow, A. W., Moyes, C. L., Drake, J.M., Brownstein, J. S., Hoen, A. G., Sankoh, O., Myers, M.F., George, D. B., Jaenisch, T, William Wint, G. R., Simmons, C. P., Scott9, T. W., Farrar, J. J. \& Hay, S. I. (2013). Global distribution and burden of dengue. Nature, 496, 504-507.

Bhavani, D., Goldstick, J. E., Cevallos, W., Trueba, G., \& Eisenberg, J. N. S. (2014). Impact of rainfall on diarrheal disease risk associated with unimproved water and sanitation. Am. J. Trop. Med. Hyg., 90(4), 705-711.

Browna, L, Medlock, J. \& Murraya, V. (2014). Impact of drought on vector-borne diseases-how does one manage the risk?. Public health, 128, 29-37.

Brownstein, J. S., Hoen, A. G., Sankoh, O., Myers, M.F., George, D. B., Jaenisch, T, William Wint, G. R., Simmons, C. P., Scott9, T. W., Farrar, J. J. \& Hay, S. I. (2013). Global distribution and burden of dengue. Nature, 496, 504-507. 
Carlton, E, J., Eisenberg J. N. S., Goldstick, J., Cevallos, W., Trostle, J. \& Levy, K. (2016). Heavy rainfall events and diarrheal incidence: The role of social and environmental factors. American Journal of Epidemiology, 179(3), 344-352.

Cox, N. (2014). Influenza seasonality: Timing and formulation of vaccines. Bulletin of the World Health Organization, 92, 311.

Davies, G. I., McIver, L., Kim, Y., Hashizume, M., Iddings, S., \& Chan, V. (2015). WaterBorne diseases and extreme weather events in Cambodia: Review of impacts and implications of climate change. Int. J. Environ. Res. Public Health, 12, 191-213.

Eisenberg, J., Desai, M., Levy, K., Bates, S. J., Liang, S., Naumoff, K., et al. (2007). Environmental determinants of infectious disease: a framework for tracking causal links and guiding public health research. Environ Health Perspect, 115, 1216-1223.

Gubler, D. J., Reiter, P., Ebi, K. L., Yap, W., Nasci R. \& Patz, J. A. (2001). Climate variability and change in the United States: potential impacts on vector- and rodent-borne diseases. Environ. Health Perspect, 109(Suppl. 2), 223-233.

Hansen, A.L., P. Bi, Ryan, P., Nitschke, M., Pisaniello, D. \& Tucker, G. (2008). The effect of heat waves on hospital admissions for renal disease in a temperate city of Australia. International Journal of Epidemiology, 37(6), 1359-1365.

Heuer, C., Benschop, J., Stringer, L., Collins-Emerson, J., Sanhueza, J., \& Peter (2012). Leptospirosis in New Zealand - best practice recommendations for the use of vaccines to prevent human exposure: A report by Massey University prepared for the New Zealand Veterinary Association. Institute of Veterinary, Animal and Biomedical Sciences, Massey University.

Hii, Y. L., Zhu, H., Ng, N., Ng, L.C. \& Rocklov, J. (2012). Forecast of dengue incidence using temperature and rainfall. PLoS Neglected Tropical Diseases, 6(11): e1908.

2.10 Hoetker, G. (2007). The use of logit and probit models in strategic management research: Critical issues. Strategic management, 28(4), 331-343.

Jutla, A., Whitcombe, E., Hasan, N., Haley, B., Akanda, A., Huq, A., Alam, M., Sack, R. B. \& Colwell, R. (2013). Environmental factors influencing epidemic cholera. American Journal of Tropical Medicine and Hygiene, 89(3), 597-607.

Karande S, Bhatt, M., Kelkar, A., et al. (2003). An observational study to detect leptospirosis in Mumbai, India. Arch. Dis. Child., 88, 1070-1075.

Kelly-Hope, L. A., Hemingway, J., \& McKenzie, F. E. (2009). Environmental factors associated with the malaria vectors Anopheles gambiae and Anopheles funestus in Kenya. Malaria Journal, 8, 268. 
Knowlton, K., Rotkin-Ellman, M., King, G., Margolis, H. G., Smith, D., Solomon, G., (2009). The 2006 California heat wave: impacts on hospitalizations and emergency department visits. Environ Health Perspect, 117, 61-67.

Knowlton, K., Rotkin-Ellman, M., Geballe, L., Max, W., and Solomon, G. M. (2011). Six climate change-related events in The United States accounted for about \$14 Billion In lost lives and Health Costs. Health Affairs, 30(11), 2167-2176.

Kondo, H., Seo, N., Yasuda, T. et al. (2002). Post flood-infectious diseases in Mozambique. Prehosp. Disaster Med., 17, 126-133.

Lai, S., Tao, H., \& Xu, Y. (2013). Abiotic determinants to the spatial dynamics of Dengue fever in Guangzhou. Asia-Pacific Journal of Public Health, 25(3), 239-247.

Lin, R. T., \& Chan, C. C. (2009). Effects of heat on workers' health and productivity in Taiwan. Glob Health Action, 2 (1).

Lu, L., Lin, H., Tian, L. Yang, W., Sun, J., \& Liu, Q. (2009). Time series analysis of dengue fever and weather in Guangzhou, China. BMC Public Health 2009, 9:395.

Lunde, O. M., Balkew, M., Korecha, D., Gebre-Michael, T., Massebo, F., Sorteberg, A., \& Lindtjørn B. (2013). A dynamic model of some malaria-transmitting anopheline mosquitoes of the Afrotropical region. II. Validation of species distribution and seasonal variations. Malaria Journal 2013, 12:78.

McFarlane, R. A., Sleigh, A. C. \& McMichael, A. J. (2013). Land-use change and emerging infectious disease on an Island Continent. Int. J. Environ. Res. Public Health, 10, 2699-2719.

Milojevic, A., Armstrong, B., Hashizume, M. et al. (2012). Health effects of flooding in rural Bangladesh. Epidemiology, 23(1), 107-115.

Nitscheke, M., Tucker, G. R., Hansen, A. L., Williams, S., Zhang, Y., \& Bi, P. (2011). Impact of two recent extreme heat episodes on morbidity and mortality in Adelaide, South Australia: a case-series analysis. Environ Health, 10 (42).

Norton, E. C., Wang, H. \& Ai, C. (2004). Computing interaction effects and standard errors in logit and probit models. The stata journal, 4(2), 154-167.

Paranjothy S., Gallacher J., Palmer, S. R., et al. (2011). Psychosocial impact of the summer 2007 floods in England. BMC public health, 11(145), 1471-2458.

Pascual M., Ahumada J. A., Chaves L. F., Rodo X., \& Bouma M. (2006). Malaria resurgence in the East African highlands: temperature trends revisited. Proc. Natl. Acad. Sci., 03(15), 5829-5834.

Qadri, F., Khan, A. I., \& Furuque, A. S. G. (2005). Enter toxigenic Escherichia coli and Vibrio cholerae diarrhoea, Bangladesh. Emerg. Infect. Dis., 11, 1104-1107. 
Sarfraz, M. S., Tripathi, N., Tipdecho, T., Thongbu, T., Kerdthong, P., \& Souris, M. (2012). Analysing the spatio-temporal relationship between dengue vector larval density and land-use using factor analysis and spatial ring mapping, BMC Public Health 2012, 12:853.

Sharma, R. (2012). Impacts on human health of climate and land use change in the Hindu Kush-Himalayan region. Mountain Research and Development, 32(4), 480486.

Sirisena, P. D. N. N. \& Noordeen, F. (2016). Dengue control in Sri Lanka - challenges and prospects for improving current strategies. Sri Lankan Journal of Infectious Diseases, 6 (1), 2-16.

Stanke, C., Kerac, M., Prudhomme, C., Medlock, J., \& Murray, V.(2013). Health effects of drought: a systematic review of the evidence. PLoS Curr., 5(5).

Thai, P. Q., Marc, C., Duong, T. N., Thiem, V. D., Yen, N. T., Hien, N. T., Weiss, D. J., Boni, M. F., \& Horby, P. (2015). Seasonality of absolute humidity explains seasonality of influenza-like illness in Vietnam. Epidemics, 13, 65-73.

Vollaard, A. M., Ali, S., van Asten, H. A., Widjaja, S., Visser, L. G, Surjadi, C., van Dissel, J. T. (2004). Risk factors for typhoid and paratyphoid fever in Jakarta, Indonesia. JAMA.291(21), 2607-15.

World Health Organization. (2005). Epidemic prone disease surveillance and response after the tsunami in Aceh Province, Indonesia. Wkly Epidemiol Rec., 80,160-164.

Wu, F., Liu, Q., Lu, L., Wang, J., Song, X., \& Ren, D. (2011). Distribution of Aedes albopictus (Diptera: Culicidae) in north-western China. Vector-Borne and Zoonotic Diseases, 11(8), 1181-1186.

Zanobetti, A., O'Neill, M.S., Gronlund, C. J., \& Schwartz J.D. (2012). Summer temperature 14 variability and long-term survival among elderly people with chronic disease. Proceedings of the 15 National Academy of Sciences, 109, 6608-6613. 


\section{Appendix 2-2: Agricultural-ecological regions in Sri Lanka}

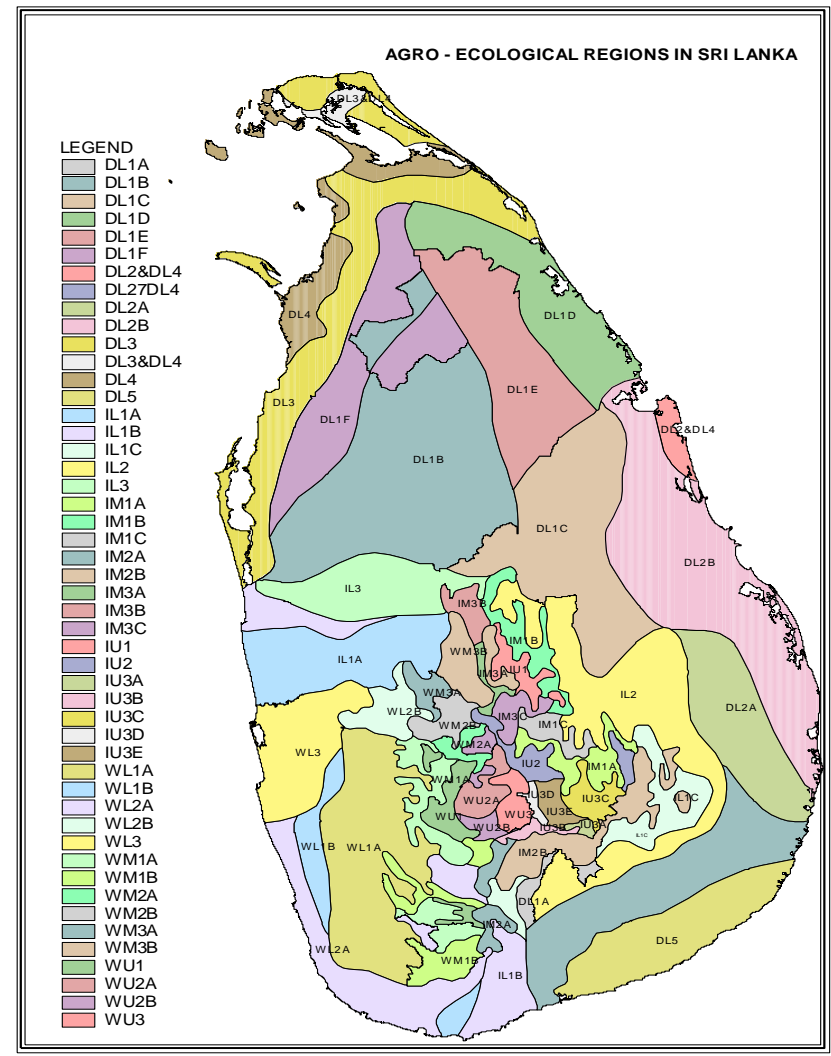

\section{Appendix 2-3: Selected cases of notifiable diseases in Sri Lanka}

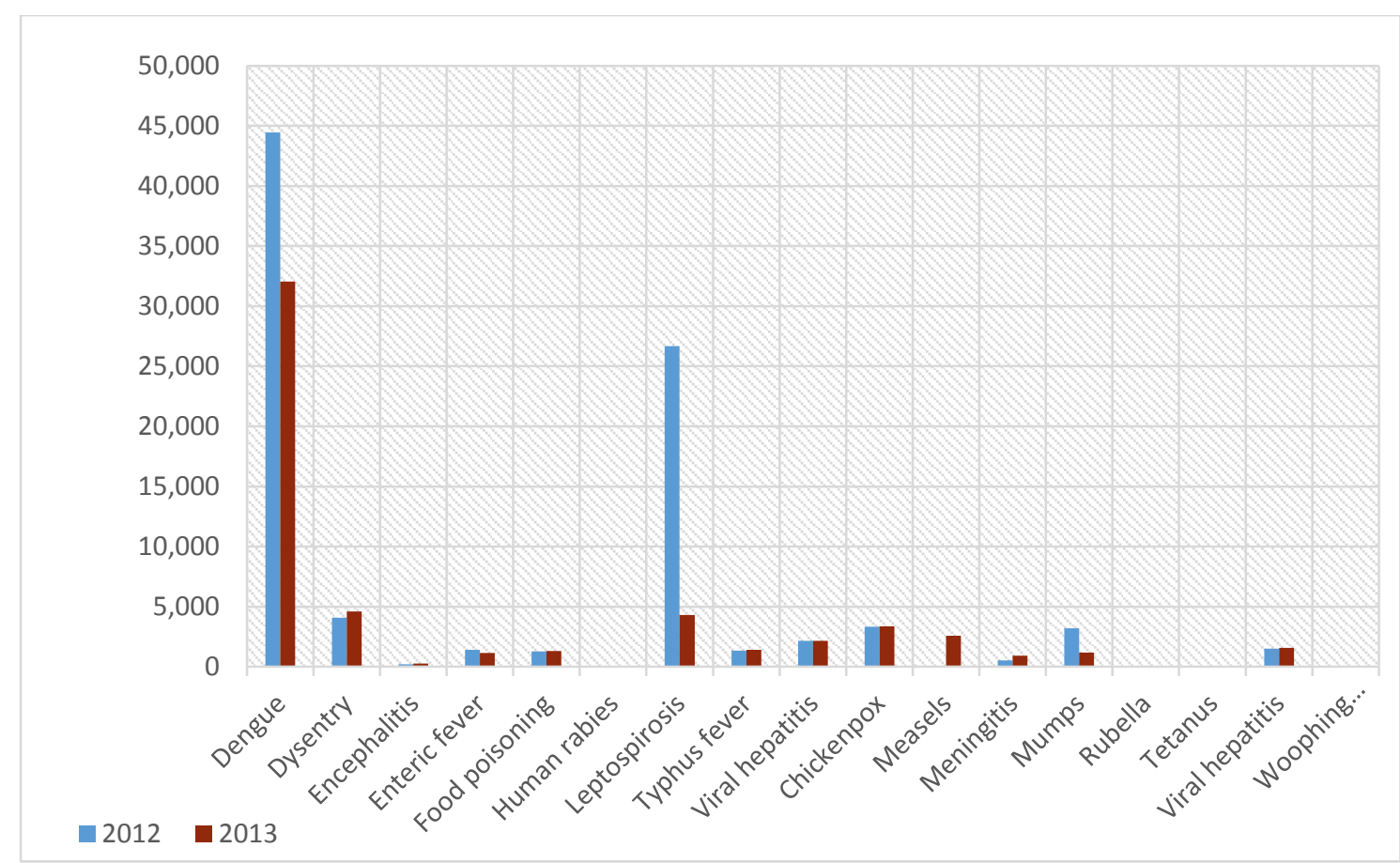

Source: Ministry of Health, Sri Lanka (2012). Annual health bulletin. Ministry of Health, Sri Lanka (2013). Annual Health Bulletin. 


\section{Appendix 2-4: Chronic illnesses in Sri Lanka}

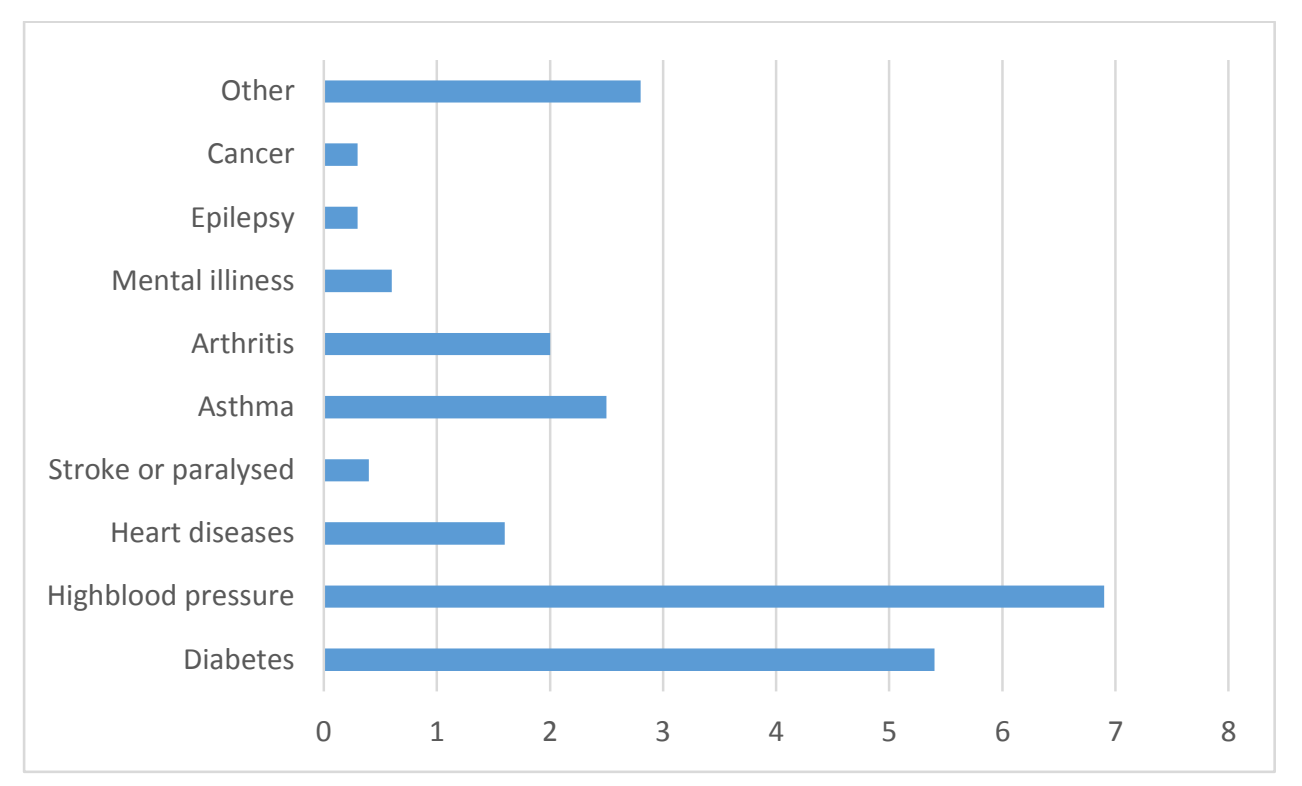

Source: Department of Census and Statistics, 2013

Appendix 2-5: Seasonality of Diseases-2012

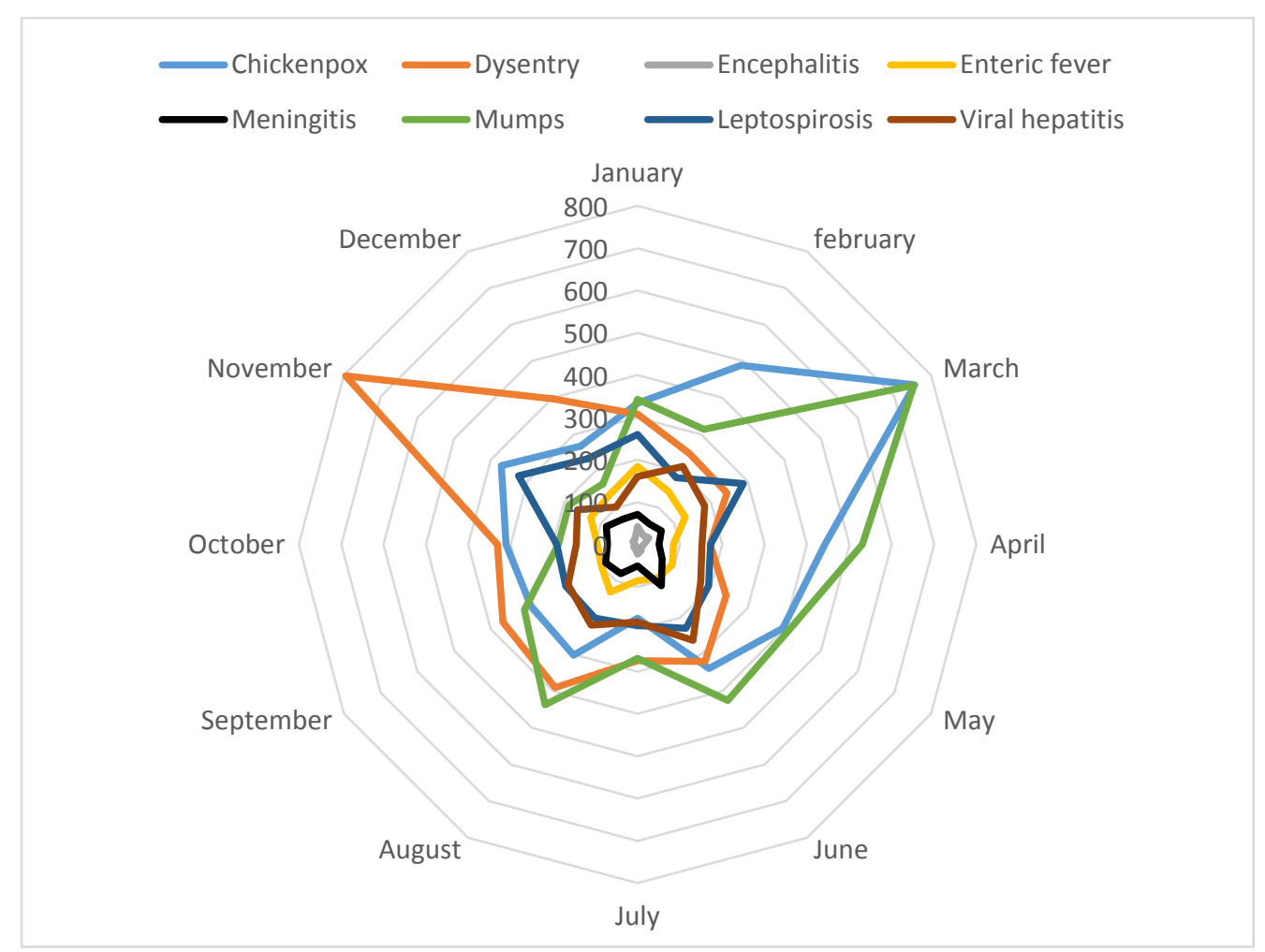

Source: Ministry of Health, Sri Lanka (2012). Annual Health Bulletin. Ministry of Health, Sri Lanka (2013). Annual Health Bulletin. 


\section{Appendix 2-6: Seasonality of Diseases 2013}

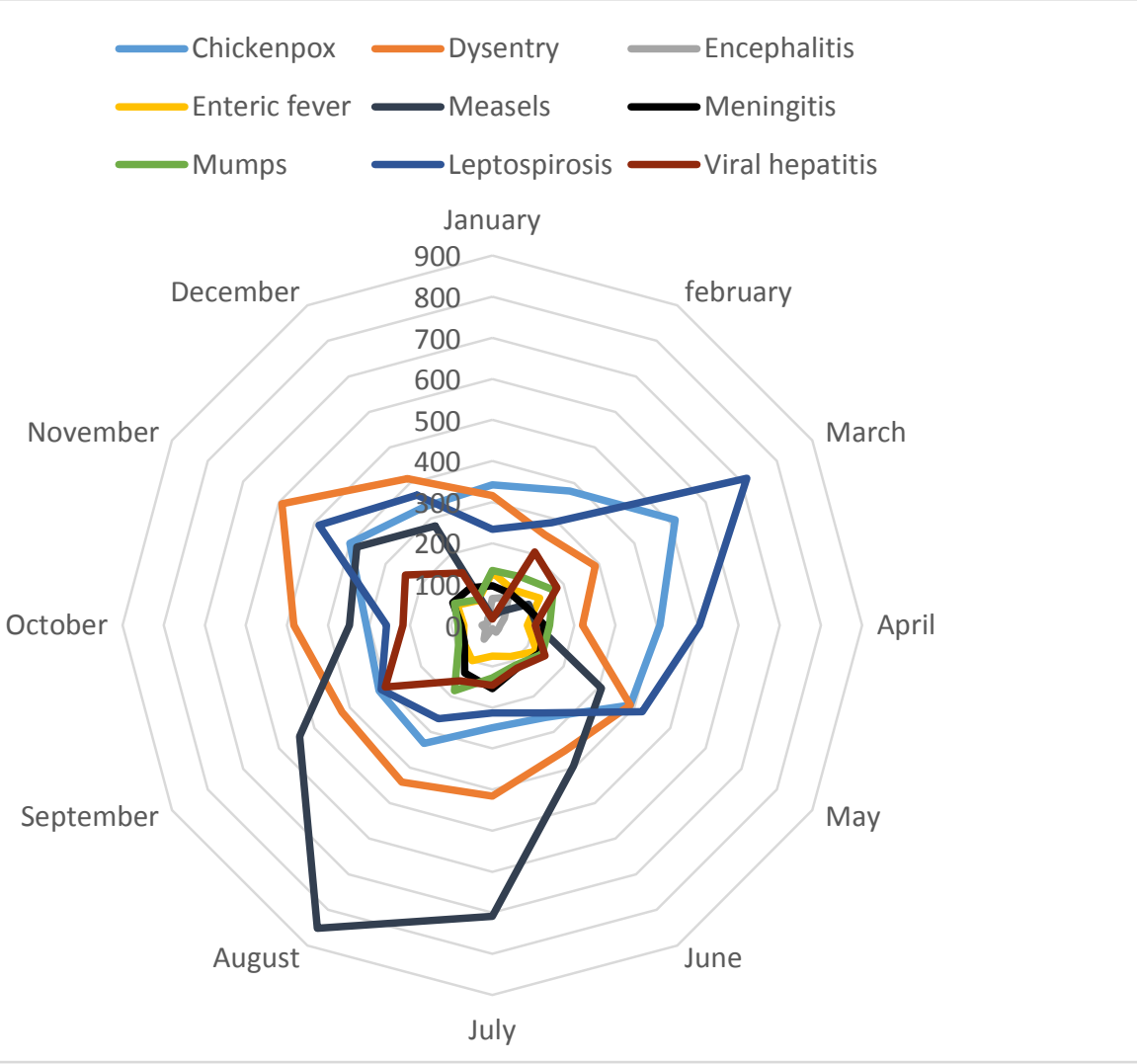

Source: Ministry of Health, Sri Lanka (2012a). Annual Health Bulletin. Ministry of Health, Sri Lanka (2013). Annual Health Bulletin.

\section{Appendix 2-7: Monthly reported Dengue cases in Sri Lanka}

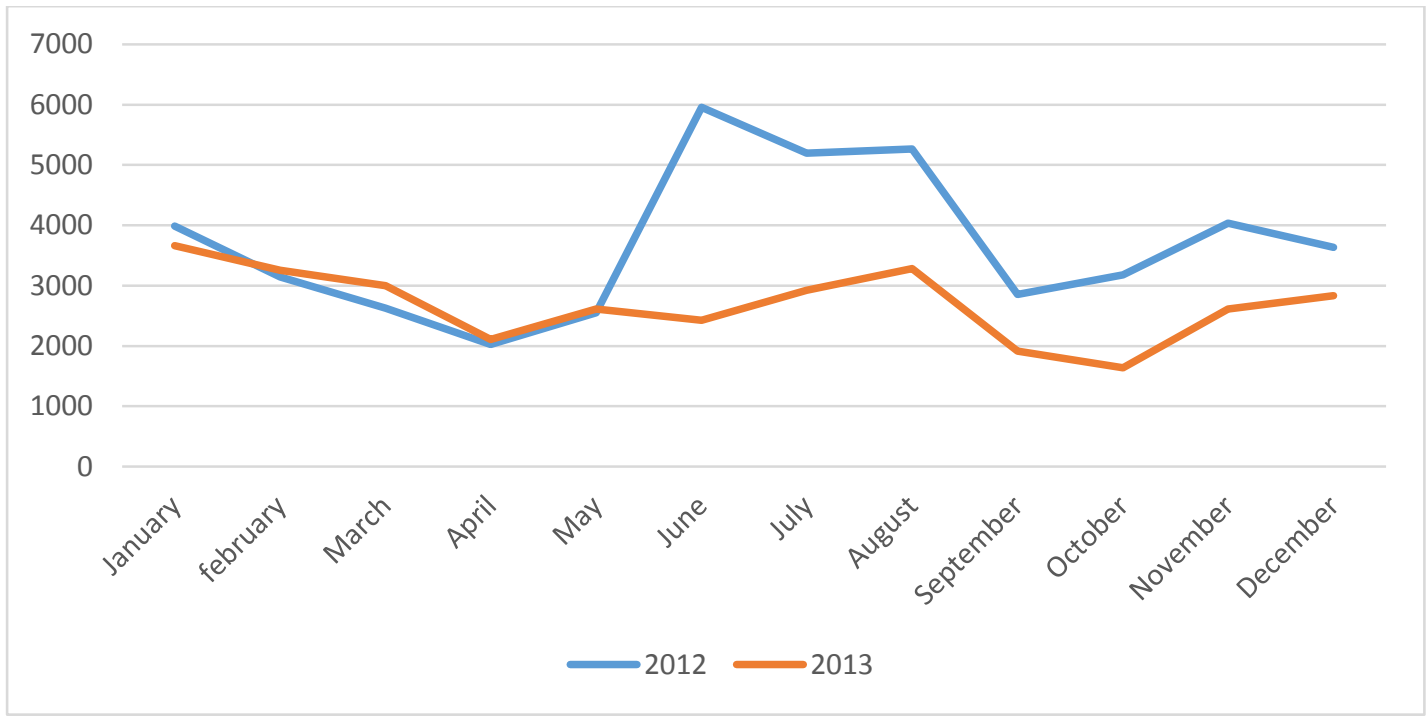

Source: Ministry of Health, Sri Lanka (2012a). Annual Health Bulletin. Ministry of Health, Sri Lanka (2013). Annual Health Bulletin. 
Appendix 2-8: District level per capita public health expenditure (Rs.)

\begin{tabular}{|c|c|c|}
\hline Province & District & $\begin{array}{c}\text { Per capita public health } \\
\text { expenditure (LKR) }\end{array}$ \\
\hline \multirow[t]{3}{*}{ Central province } & Nuwaraeliya & 3596 \\
\hline & Matale & 3626 \\
\hline & Kandy & 6802 \\
\hline \multirow[t]{3}{*}{ Eastern province } & Trincomalee & 3590 \\
\hline & Batticaloa & 4966 \\
\hline & Ampara & 5246 \\
\hline \multirow[t]{2}{*}{ North central province } & Polonnaruwa & 4952 \\
\hline & Anuradhapura & 5805 \\
\hline \multirow[t]{2}{*}{ North western province } & Puttlam & 3840 \\
\hline & Kurunegala & 6802 \\
\hline \multirow[t]{5}{*}{ Northern province } & Kilinochchi & 2707 \\
\hline & Mannar & 2817 \\
\hline & Mulativu & 3049 \\
\hline & Vavuniya & 3169 \\
\hline & Jaffna & 4845 \\
\hline \multirow[t]{2}{*}{ Sabaragamuwa } & Kegalle & 4267 \\
\hline & Ratnapura & 4989 \\
\hline \multirow[t]{3}{*}{ Southern } & Matara & 4076 \\
\hline & Hambantota & 4394 \\
\hline & Galle & 5415 \\
\hline \multirow[t]{2}{*}{ Uva } & Moneragala & 3727 \\
\hline & Badulla & 5680 \\
\hline \multirow[t]{3}{*}{ Western } & Gampaha & 5979 \\
\hline & Kalutara & 6464 \\
\hline & Colombo & 7278 \\
\hline
\end{tabular}




\section{Appendix 2-9: Diseases in Sri Lanka}

\begin{tabular}{|c|c|c|c|c|}
\hline Disease & $\begin{array}{l}\text { Infectious agent and } \\
\text { symptoms }\end{array}$ & $\begin{array}{l}\text { Mode of transmission and } \\
\text { Risk factors }\end{array}$ & Reservoir & $\begin{array}{lll}\text { Report In Sri } \\
\text { Lanka }\end{array}$ \\
\hline $\begin{array}{lr}\text { ACUTE } & \text { LOWER } \\
\text { RESPIRATORY } & \text { TRACT } \\
\text { INFECTION } & \\
\end{array}$ & $\begin{array}{l}\text { Bacterial, viral and } \\
\text { other gram-negative } \\
\text { organisms }\end{array}$ & $\begin{array}{l}\text { Poor hygiene, food shortage, } \\
\text { lack of safe drinking water. } \\
\text { No seasonality }\end{array}$ & & Reported in 2012 \\
\hline $\begin{array}{ll}\text { BACILLARY DYSENTERY } \\
\text { (SHIGELLOSIS) }\end{array}$ & Bacteria & $\begin{array}{l}\text { Faecal oral route, particularly } \\
\text { through contaminated water } \\
\text { and food. Flies may also } \\
\text { transmit the organism. }\end{array}$ & Humans, primates & Reported in 2012 \\
\hline CHIKUNGUNYA FEVER & Chikungunya virus & $\begin{array}{l}\text { Transmitted through } \\
\text { Mosquitoes (two types). } \\
\text { Mosquito breeds primarily in } \\
\text { water in natural and artificial } \\
\text { containers. Mosquito's eggs } \\
\text { can remain viable throughout } \\
\text { the dry season, giving rise to } \\
\text { larvae and adults the } \\
\text { following rainy season. One is } \\
\text { a tree-hole mosquito in } \\
\text { natural areas, and breeds } \\
\text { around garden bush } \\
\text { vegetation in urban areas. } \\
\text { Occur year-round Outbreaks } \\
\text { in Rainy season }\end{array}$ & $\begin{array}{l}\text { Mainly humans, } \\
\text { and also find in } \\
\text { monkeys, rodents, } \\
\text { birds and other } \\
\text { unidentified } \\
\text { vertebrates }\end{array}$ & $\begin{array}{l}\text { Outbreak in Sri } \\
\text { lanka2006-7, } \\
2008-9\end{array}$ \\
\hline CHOLERA & $\begin{array}{l}\text { Bacteria (bacterium } \\
\text { Vibrio cholera) }\end{array}$ & $\begin{array}{l}\text { Transmitted mainly by the } \\
\text { faecal-oral route: poor } \\
\text { hygiene, contaminated water, } \\
\text { food, person to person, } \\
\text { Seasonality: Wet seasons, } \\
\text { during floods. }\end{array}$ & $\begin{array}{l}\text { Human, Cepodes } \\
\text { and zooplankton } \\
\text { in brackish water } \\
\text { or estuaries. }\end{array}$ & $\begin{array}{l}\text { Last reported in } \\
2003 \text { in Sri } \\
\text { Lanka. }\end{array}$ \\
\hline DENGUE & Viral & $\begin{array}{l}\text { Transmitted by mosquitoes } \\
\text { (Aedes aegypti). } \\
\text { Accumulation of water } \\
\text { increase vector breeding } \\
\text { Seasonality: } \\
\text { June and July with south } \\
\text { western monsoon } \\
\text { October to December with } \\
\text { North Eastern monsoon }\end{array}$ & Mosquito born & $1965-2016$ \\
\hline DIARRHOEAL DISEASES & $\begin{array}{lr}\text { Different } & \text { viral, } \\
\text { bacterial and parasitic } \\
\text { infectious agents } \\
\text { (protozoa) }\end{array}$ & $\begin{array}{l}\text { Transmitted through faecal- } \\
\text { oral route, particularly } \\
\text { through contaminated water } \\
\text { and food. Population } \\
\text { movements, lack of safe }\end{array}$ & $\begin{array}{l}\text { Human are the } \\
\text { main reservoirs } \\
\text { and additionally } \\
\text { carried by cattle }\end{array}$ & \\
\hline
\end{tabular}




\begin{tabular}{|c|c|c|c|c|}
\hline & & $\begin{array}{l}\text { water, poor hygiene practices } \\
\text { and poor sanitation } \\
\text { Reported January-March } \\
\text { (due to rota virus) }\end{array}$ & & \\
\hline DIPHTHERIA & $\begin{array}{l}\text { Bacteria } \\
\text { affects mucus } \\
\text { membrane and } \\
\text { respiratory tract }\end{array}$ & $\begin{array}{l}\text { By contact (person to person } \\
\text { contaminated droplets), } \\
\text { contaminated food, and over } \\
\text { crowding }\end{array}$ & Humans & $\begin{array}{l}\text { No recent } \\
\text { outbreaks }\end{array}$ \\
\hline HEPATITIS A AND E & $\begin{array}{l}\text { Virial (hepatitis A and } \\
\text { E) } \\
\text { Cause inflammation of } \\
\text { the liver. }\end{array}$ & $\begin{array}{l}\text { Hepatitis A is transmitted: } \\
\text { person to person, via the } \\
\text { faecal-oral route, } \\
\text { contaminated food } \\
\text { contaminated drinking- } \\
\text { water, raw or uncooked } \\
\text { shellfish, zoonotic infection, } \\
\text { Risk factors: population } \\
\text { movement, hygiene, } \\
\text { sanitation, contaminated } \\
\text { water } \\
\text { Seasonality: Perennial }\end{array}$ & $\begin{array}{l}\text { Human, primates, } \\
\text { as well as pigs, } \\
\text { cows, sheep, goats } \\
\text { and rodents }\end{array}$ & $\begin{array}{l}\text { Reported :2007, } \\
2008,2012\end{array}$ \\
\hline INFLUENZA & $\begin{array}{l}\text { viral (influenza viruses } \\
\text { A, B and C) } \\
\text { affects mainly the nose, } \\
\text { throat, bronchi and, } \\
\text { occasionally, the lungs: }\end{array}$ & $\begin{array}{l}\text { Overcrowding, poor hygiene, } \\
\text { food shortage } \\
\text { Seasonality: occur } \\
\text { throughout the year. Low } \\
\text { temperatures and dry } \\
\text { conditions contribute to } \\
\text { longer survival of the virus in } \\
\text { the environment }\end{array}$ & & $\begin{array}{l}\text { No out breaks in } \\
\text { Sri Lanka. } \\
\text { Reported } \\
\text { Influenza like } \\
\text { illness in } 2012\end{array}$ \\
\hline JAPANESE ENCEPHALITIS & $\begin{array}{l}\text { Viral } \\
\text { Associated with } \\
\text { neurological } \\
\text { symptoms ranging } \\
\text { from headache to } \\
\text { encephalitis } \\
\text { meningitis }\end{array}$ & $\begin{array}{l}\text { Transmitted by the bite of an } \\
\text { infected mosquito (Culex } \\
\text { species) which breed } \\
\text { particularly in flooded rice } \\
\text { fields. Larvae are found in } \\
\text { many temporary, semi- } \\
\text { permanent and permanent } \\
\text { groundwater habitats that } \\
\text { are sunlit and contain } \\
\text { vegetation. Habitats include } \\
\text { ground pools, streams, } \\
\text { swamps and low-salinity } \\
\text { tidal marshes. Seasonality: } \\
\text { occur throughout the year } \\
\text { with a peak after the start of } \\
\text { the rainy season. }\end{array}$ & $\begin{array}{l}\text { Pigs, birds, horses, } \\
\text { bats, cattle and } \\
\text { reptiles }\end{array}$ & $2005-2012$ \\
\hline $\begin{array}{l}\text { LEISHMANIASIS } \\
\text { CUTANEOUS }\end{array}$ & $\begin{array}{l}\text { Several species of } \\
\text { protozoan }\end{array}$ & $\begin{array}{l}\text { Transmit from human-to- } \\
\text { human transmission occurs }\end{array}$ & $\begin{array}{l}\text { humans are the } \\
\text { sole reservoir }\end{array}$ & Reported in 2012 \\
\hline
\end{tabular}




\begin{tabular}{|c|c|c|c|c|}
\hline & $\begin{array}{l}\text { Cause ulcerative skin } \\
\text { lesions, multiple non- } \\
\text { ulcerative nodules, } \\
\text { destructive mucosal } \\
\text { inflammation, } \\
\text { disseminated visceral } \\
\text { infection }\end{array}$ & $\begin{array}{l}\text { via sand-fly bites and (rarely) } \\
\text { through blood transfusion } \\
\text { Risk factors: Population } \\
\text { movement, overcrowding, } \\
\text { epidemics are linked to } \\
\text { human migration, poor } \\
\text { health, poor housing and } \\
\text { sanitation } \\
\text { mostly in low-altitude areas } \\
\text { no seasonality }\end{array}$ & & \\
\hline LEPROSY & $\begin{array}{l}\text { bacterial } \\
\text { affects the skin and } \\
\text { peripheral nerves. }\end{array}$ & $\begin{array}{l}\text { The exact mode of } \\
\text { transmission is unknown. } \\
\text { The disease is thought to be } \\
\text { transmitted by air through } \\
\text { droplets from the nose and } \\
\text { mouth, during close and } \\
\text { frequent contacts with } \\
\text { untreated cases. } \\
\text { Not follow a seasonal pattern. }\end{array}$ & $\begin{array}{l}\text { Humans are } \\
\text { thought to be the } \\
\text { only significant } \\
\text { reservoir. }\end{array}$ & $\begin{array}{lr}\text { Sri } & \text { Lanka } \\
\text { achieved } & \text { a } \\
\text { leprosy } & \\
\text { elimination } & \text { goal } \\
\text { nationally } & \text { in } \\
1996 . & \end{array}$ \\
\hline LEPTOSPIROSIS & bacteria & $\begin{array}{l}\text { Carrier animals excrete the } \\
\text { organism in their urine, } \\
\text { thereby contaminating the } \\
\text { environment. Human } \\
\text { infection occurs either by } \\
\text { direct contact with infected } \\
\text { urine or tissues, or by } \\
\text { indirect exposure to the } \\
\text { organisms in damp soil or } \\
\text { water. } \\
\text { Seasonality: } \\
\text { throughout the year, peak at } \\
\text { the time of the monsoons, a } \\
\text { smaller one in March to May, } \\
\text { and a larger one in October to } \\
\text { December. High humidity } \\
\text { and heavy rainfall intensify } \\
\text { outbreaks. Most patients } \\
\text { with leptospirosis have been } \\
\text { exposed to paddy fields. }\end{array}$ & $\begin{array}{l}\text { Reservoirs include } \\
\text { both wild and } \\
\text { domestic animals; } \\
\text { for example, rats, } \\
\text { pigs, cattle and } \\
\text { dogs. }\end{array}$ & $\begin{array}{l}2008, \text { outbreak, } \\
\text { Reported also in } \\
2012 .\end{array}$ \\
\hline LYMPHATIC FILARIASIS & $\begin{array}{l}\text { Disease is caused by } \\
\text { thread-like worms } \\
\text { (filariae). } \\
\text { Symptoms: fevers can } \\
\text { occur several times a } \\
\text { year, which lodge in } \\
\text { can lead to temporary }\end{array}$ & $\begin{array}{l}\text { Repeated bites of infected, } \\
\text { blood-feeding, female } \\
\text { mosquitoes (mainly Culex } \\
\text { species) transmit immature } \\
\text { larval forms of the parasitic } \\
\text { worms from human to } \\
\text { human. }\end{array}$ & $\begin{array}{l}\text { Humans are the } \\
\text { only reservoirs for } \\
\text { W. bancrofti. }\end{array}$ & \\
\hline
\end{tabular}




\begin{tabular}{|c|c|c|c|c|}
\hline & $\begin{array}{ll}\text { and } & \text { permanent } \\
\text { disability. } & \end{array}$ & $\begin{array}{l}\text { Seasonality: Transmission } \\
\text { risk is likely to increase } \\
\text { during the rainy season, }\end{array}$ & & \\
\hline MALARIA & $\begin{array}{l}\text { Symptoms of malaria } \\
\text { are nonspecific, and } \\
\text { are similar to the } \\
\text { symptoms of a minor, } \\
\text { systemic viral illness. } \\
\text { Infectious agent: The } \\
\text { main malaria parasite } \\
\text { species in Sri Lanka is } \\
\text { Plasmodium vivax. } \\
\text { Only } 6.5 \% \text { of cases in } \\
2008 \text { were transmitted } \\
\text { by P. falciparum. }\end{array}$ & $\begin{array}{l}\text { Malaria is transmitted by } \\
\text { mosquitoes. The vector is the } \\
\text { female Anopheles mosquito. } \\
\text { Factors that influence } \\
\text { malaria transmission } \\
\text { include: altitude (in Sri Lanka } \\
\text { malaria can occur up to } \\
1200 \text { m), rainfall, humidity, } \\
\text { temperature and vegetation. } \\
\text { Transmission occurs year- } \\
\text { round throughout the } \\
\text { country, with seasonal peaks } \\
\text { during and just after the } \\
\text { monsoon rains. }\end{array}$ & $\begin{array}{l}\text { There are no } \\
\text { significant animal } \\
\text { reservoirs for } \\
\text { malaria. }\end{array}$ & $\begin{array}{l}\text { Reported: up to } \\
2008\end{array}$ \\
\hline MEASLES & $\begin{array}{l}\text { Measles is a highly } \\
\text { communicable disease, } \\
\text { characterized by a } \\
\text { prodrome of fever, } \\
\text { conjunctivitis (i.e. red } \\
\text { eyes), coryza (i.e. } \\
\text { runny nose), cough, } \\
\text { small whitish spots on } \\
\text { the buccal mucosa } \\
\text { (inside the mouth) } \\
\text { called Koplik spots, } \\
\text { and a characteristic, } \\
\text { red blotchy rash } \\
\text { appearing between } \\
\text { days } 3 \text { and } 7 \text { of the } \\
\text { illness. } \\
\text { Infectious agent: The } \\
\text { infectious agent is the } \\
\text { measles virus (genus } \\
\text { Morbillivirus, family } \\
\text { Paramyxoviridae). }\end{array}$ & $\begin{array}{l}\text { Population movement, } \\
\text { overcrowding, } \\
\text { lack of safe water, poor } \\
\text { hygiene practices and poor } \\
\text { sanitation usually have poor } \\
\text { nutrition and repeated } \\
\text { attacks } \\
\text { No seasonality }\end{array}$ & $\begin{array}{l}\text { Humans are the } \\
\text { reservoir } \\
\text { measles. }\end{array}$ & $\begin{array}{l}\text { Pre- } \\
\text { immunization is } \\
\text { available from } \\
1984 \text { in Sri Lanka } \\
\text { for lifetime } \\
\text { immunity. } \\
\text { Reported in } 2012\end{array}$ \\
\hline MENINGOCOCCAL DISEASE & $\begin{array}{l}\text { Bacterial } \\
3 \text { main clinical forms: } \\
\text { the meningeal } \\
\text { syndrome, the septic } \\
\text { form and pneumonia. } \\
\text { Can cause death, } \\
\text { survivors can have } \\
\text { persistent neurological } \\
\text { defects }\end{array}$ & $\begin{array}{l}\text { Poor respiratory etiquette } \\
\text { facilitates transmission and } \\
\text { Population movement } \\
\text { No information available on } \\
\text { seasonality in Sri Lanka. }\end{array}$ & $\begin{array}{l}\text { Humans are the } \\
\text { reservoir for } \\
\text { meningococcal } \\
\text { disease. }\end{array}$ & \begin{tabular}{l}
\multicolumn{2}{l}{ Notifiable } \\
disease in Sri \\
Lanka rrom \\
2005. Reported \\
in 2012.
\end{tabular} \\
\hline
\end{tabular}




\begin{tabular}{|c|c|c|c|c|}
\hline $\begin{array}{l}\text { PERTUSSIS (WHOOPING } \\
\text { COUGH) }\end{array}$ & $\begin{array}{l}\text { Bacteria } \\
\text { Initial stage is similar } \\
\text { to the common cold } \\
\text { sudden burst of } \\
\text { numerous rapid (near- } \\
\text { violent) coughs } \\
\text { followed by a long } \\
\text { inspiratory effort, High } \\
\text { in under year } 1\end{array}$ & $\begin{array}{l}\text { Mass population movement } \\
\text { and Crowded condition } \\
\text { facilitate transmission. } \\
\text { No seasonality reported. }\end{array}$ & $\begin{array}{l}\text { Humans are the } \\
\text { only hosts of } \\
\text { pertussis. }\end{array}$ & Reported in 2012 \\
\hline POLIOMYELITIS & \begin{tabular}{l}
\multicolumn{2}{l}{ Virus (Poliovirus) } \\
Cause acute flaccid \\
paralysis $\quad$ (AFP); \\
however, this \\
symptom occurs in less \\
than 1\% of Poliovirus \\
infections.
\end{tabular} & $\begin{array}{l}\text { Sri Lanka eradicated in } 1993 . \\
\text { However, Sri Lanka is at risk } \\
\text { as close to poliomyelitis } \\
\text { endemic India. } \\
\text { Transmission } \\
\text { poliomyelitis is higher during } \\
\text { the rainy season. }\end{array}$ & $\begin{array}{ll}\text { Humans are the } \\
\text { reservoir for } \\
\text { Poliovirus. }\end{array}$ & $\begin{array}{l}\text { No report after } \\
1993 . \\
\text { Acute flaccid } \\
\text { Paralysis cases } \\
\text { reported (75) in } \\
\text { Sri Lanka. }\end{array}$ \\
\hline RABIES & $\begin{array}{l}\text { Viral (zoonotic viral } \\
\text { disease) } \\
\text { Causes paresis or } \\
\text { paralysis, delirium and } \\
\text { convulsions. }\end{array}$ & $\begin{array}{l}\text { Transmitted through contact } \\
\text { with or bite of an infected } \\
\text { animal. } \\
\text { Overcrowding with dog } \\
\text { population density parallels } \\
\text { human population density } \\
\text { increase risk. } \\
\text { No seasonality }\end{array}$ & $\begin{array}{l}\text { Dogs are the main } \\
\text { reservoir and } \\
\text { vector of rabies in } \\
\text { Sri Lanka }\end{array}$ & Reported in 2012 \\
\hline $\begin{array}{l}\text { SOIL-TRANSMITTED } \\
\text { HELMINTHIASES: } \\
\text { ASCARIASIS, HOOKWORM } \\
\text { INFECTION } \\
\text { TRICHURIASIS }\end{array}$ & $\begin{array}{l}\text { Worm } \\
\text { Symptoms, including } \\
\text { intestinal } \\
\text { manifestations } \\
\text { (diarrhoea and } \\
\text { abdominal pain), } \\
\text { general malaise and } \\
\text { weakness. These } \\
\text { symptoms may affect } \\
\text { working and learning } \\
\text { capacities and impair } \\
\text { physical growth. }\end{array}$ & $\begin{array}{l}\text { Risk factors are poor } \\
\text { sanitation, hygienic } \\
\text { condition. } \\
\text { Seasonal Distribution is } \\
\text { influenced by environmental } \\
\text { parameters - especially } \\
\text { temperature, humidity and } \\
\text { soil dryness - that affect the } \\
\text { survival of eggs and larvae in } \\
\text { the environment. } \\
\text { Transmission is most intense } \\
\text { immediately after rainy } \\
\text { seasons and is lowest during } \\
\text { prolonged dry seasons. }\end{array}$ & $\begin{array}{l}\text { Humans are the } \\
\text { reservoir }\end{array}$ & Report common. \\
\hline TETANUS & $\begin{array}{l}\text { Bacteria (C. tetani) } \\
\text { Causes muscle spasm } \\
\text { and contraction, with } \\
\text { the characteristic fixed } \\
\text { smile, locked jaw and } \\
\text { arching back, and }\end{array}$ & $\begin{array}{l}\text { Transmission: } \\
\text { C. tetani spores-found in soil } \\
\text { and in the gastrointestinal } \\
\text { tracts of animals (including } \\
\text { humans) - are introduced } \\
\text { into the body through any } \\
\text { type of wound }\end{array}$ & $\begin{array}{l}\text { Tetanus spores } \\
\text { are ubiquitous in } \\
\text { the environment } \\
\text { and is a normal } \\
\text { and harmless } \\
\text { inhabitant of the } \\
\text { intestines of }\end{array}$ & \\
\hline
\end{tabular}




\begin{tabular}{|c|c|c|c|c|}
\hline & $\begin{array}{ll}\text { sudden, } & \text { generalized } \\
\text { seizures. } & \end{array}$ & Not seasonal & $\begin{array}{lr}\text { horses, } & \text { other } \\
\text { animals } & \text { and } \\
\text { humans. } & \end{array}$ & \\
\hline TUBERCULOSIS & $\begin{array}{l}\text { Bacteria } \\
\text { (Mycobacterium } \\
\text { tuberculosis) } \\
\text { Symptom: productive } \\
\text { cough of long duration } \\
\text { (> 2weeks). }\end{array}$ & $\begin{array}{l}\text { transmitted by exposure to } \\
\text { tubercle bacilli in airborne- } \\
\text { droplet } \\
\text { No seasonality }\end{array}$ & $\begin{array}{l}\text { Humans are the } \\
\text { main reservoir for } \\
\text { TB; in some areas, } \\
\text { diseased cattle are } \\
\text { reservoirs. }\end{array}$ & \\
\hline $\begin{array}{l}\text { TYPHOID FEVER (ENTERIC } \\
\text { FEVER) }\end{array}$ & $\begin{array}{l}\text { Bacteria, characterized } \\
\text { by insidious onset of } \\
\text { sustained fever, severe } \\
\text { headache, nausea, loss } \\
\text { of appetite, malaise, } \\
\text { constipation or } \\
\text { sometimes diarrhoea. }\end{array}$ & $\begin{array}{l}\text { Risk factors: Complex } \\
\text { emergency settings with } \\
\text { population movement, } \\
\text { unavailability of safe food } \\
\text { and water, and access to } \\
\text { adequate sanitation facilities } \\
\text { Most cases occur between } \\
\text { January and March; the } \\
\text { fewest occur between July } \\
\text { and September. }\end{array}$ & $\begin{array}{l}\text { Humans are the } \\
\text { reservoir for both } \\
\text { typhoid and } \\
\text { paratyphoid. }\end{array}$ & $\begin{array}{lr}\text { No recent } \\
\text { outbreaks } \quad \text { of } \\
\text { typhoid } & \text { fever } \\
\text { have reen } \\
\text { reported in Sri } \\
\text { Lanka. }\end{array}$ \\
\hline
\end{tabular}

Source: WHO 2010 


\section{Appendix 2-10: Restricted models}

\begin{tabular}{|c|c|c|c|c|c|c|c|c|c|c|c|c|c|c|c|c|}
\hline \multirow{2}{*}{$\begin{array}{l}\text { Variables } \\
\text { Self-reported flood } \\
\text { (Dummy) }\end{array}$} & \multicolumn{10}{|c|}{ Inpatient Visits } & \multicolumn{6}{|c|}{ Outpatient visits } \\
\hline & \multicolumn{2}{|l|}{ (i) } & \multicolumn{2}{|l|}{ (ii) } & \multicolumn{2}{|c|}{ (iii) } & \multicolumn{2}{|l|}{ (iv) } & \multicolumn{2}{|c|}{$\begin{array}{l}\text { Linear probability } \\
\text { model }\end{array}$} & (v) & \multicolumn{3}{|c|}{ (vi) } & \multicolumn{2}{|c|}{$\begin{array}{l}\text { Linear probability } \\
\text { model }\end{array}$} \\
\hline $\begin{array}{l}\text { Self-reported flood } \\
\text { (Dummy) } \\
\text { Flood spill over(Dummy) } \\
\text { Self-reported Drought } \\
\text { (Dummy) } \\
\text { Drought spill over } \\
\text { (Dummy) } \\
\text { Flood_D05strict level } \\
\text { Drought_District level }\end{array}$ & $\begin{array}{l}0.02^{* *} \\
0.01^{* *}\end{array}$ & $\begin{array}{l}(0.005) \\
(0.003)\end{array}$ & 0.009 & $(0.008)$ & $\begin{array}{l}0.07 \\
0.05\end{array}$ & $\begin{array}{l}(0.05) \\
(0.05)\end{array}$ & $0.03^{* *}$ & $(0.01)$ & $\begin{array}{l}0.02^{*} \\
0.01^{* * *} \\
0.12 \\
0.09\end{array}$ & $\begin{array}{l}(0.01) \\
(0.004) \\
(0.10) \\
(0.10)\end{array}$ & -0.00 & $(0.007)$ & $0.03 * *$ & $(0.01)$ & $\begin{array}{l}0.00 \\
0.03^{* *}\end{array}$ & $\begin{array}{l}(0.008) \\
(0.01)\end{array}$ \\
\hline Shared Toilet(Dummy) & $0.02^{* * *}$ & $(0.005)$ & $0.02^{* * *}$ & $(0.005)$ & $0.02^{* * *}$ & $(0.005)$ & $0.02^{* *}$ & $(0.005)$ & $0.02^{* * *}$ & $(0.006)$ & $0.03^{* * *}$ & $(0.009)$ & $0.03^{* * *}$ & $(0.009)$ & $0.02^{* * *}$ & $(0.008)$ \\
\hline $\begin{array}{l}\text { Public Toilet (Dummy) } \\
\text { Drink_Water_well(Dum } \\
\text { my) }\end{array}$ & $\begin{array}{l}0.04^{* * *} \\
0.01^{* *}\end{array}$ & $\begin{array}{l}(0.003) \\
(0.005)\end{array}$ & $\begin{array}{l}0.04^{* * *} \\
0.01^{*}\end{array}$ & $\begin{array}{l}(0.004) \\
(0.005)\end{array}$ & $\begin{array}{l}0.04^{* * *} \\
0.01^{*}\end{array}$ & $\begin{array}{l}(0.004) \\
(0.005)\end{array}$ & $\begin{array}{l}0.04^{* * *} \\
0.01^{* *}\end{array}$ & $\begin{array}{l}(0.004) \\
(0.005)\end{array}$ & $\begin{array}{l}0.04^{* * *} \\
0.01^{* * *}\end{array}$ & $\begin{array}{l}(0.005) \\
(0.004)\end{array}$ & $\begin{array}{l}0.01 \\
0.00\end{array}$ & $\begin{array}{l}(0.01) \\
(0.007)\end{array}$ & $\begin{array}{l}0.02^{*} \\
0.00\end{array}$ & $\begin{array}{l}(0.01) \\
(0.007)\end{array}$ & 0.01 & $(0.01)$ \\
\hline $\begin{array}{l}\text { Drinking water unsafe } \\
\text { source(Dummy) }\end{array}$ & 0.00 & $(0.006)$ & 0.00 & $(0.005)$ & 0.00 & $(0.006)$ & -0.00 & $(0.006)$ & -0.00 & $(0.006)$ & -0.00 & $(0.01)$ & -0.00 & $(0.01)$ & -0.00 & $(0.01)$ \\
\hline Month fixed effects & Yes & & Yes & & Yes & & Yes & & Yes & & No & & No & & No & \\
\hline District fixed effects & Yes & & Yes & & Yes & & Yes & & Yes & & Yes & & Yes & & Yes & \\
\hline District land use (\%) & No & & No & & No & & No & & No & & No & & No & & No & \\
\hline Pseudo R2 & 0.04 & & 0.04 & & 0.04 & & 0.04 & & 0.28 & & 0.05 & & 0.05 & & 0.43 & \\
\hline
\end{tabular}

Notes: Robust standard errors in the bracket. $* * * * * *$, stand for significance at $1 \%, 5 \%$ and $10 \%$ respectively. There are 79381 observations

Structural covariates include sex, age, years of education, ethnicity, employment status, live in rural sector, live in estate sector, income, and

ime to hospital. 
Appendix 2-11: Immediate health effects of flood: Outpatient treatments for different groups

\begin{tabular}{|c|c|c|c|c|c|c|c|c|c|c|}
\hline Variables & Rural & & Urban & & Estate & & Young & & Old & \\
\hline Flood (Dummy) & 0.01 & $(0.01)$ & -0.01 & $(0.01)$ & -0.02 & $(0.04)$ & 0.01 & $(0.01)$ & 0.007 & $(0.009)$ \\
\hline Drought(Dummy) & $0.03 *$ & $(0.02)$ & 0.01 & $(0.03)$ & 0.01 & $(0.02)$ & $0.03 * * *$ & $(0.01)$ & 0.01 & $(0.01)$ \\
\hline Shared Toilet (Dummy) & $0.04 * * *$ & $(0.01)$ & -0.01 & $(0.01)$ & $0.03 * *$ & $(0.01)$ & $0.03 * * *$ & $(0.01)$ & $0.02 * *$ & $(0.01)$ \\
\hline Public Toilet (Dummy) & 0.02 & $(0.02)$ & 0.01 & $(0.02)$ & 0.02 & $(0.02)$ & 0.01 & $(0.01)$ & $0.04 * * *$ & $(0.01)$ \\
\hline Drinking Water well(Dummy) & -0.001 & (0.01) & 0.003 & $(0.008)$ & $0.06 * *$ & (0.03) & 0.01 & $(0.01)$ & 0.00 & $(0.008)$ \\
\hline Drinking water unsafe source(Dummy) & -0.004 & $(0.01)$ & -0.001 & $(0.01)$ & 0.04 & $(0.03)$ & -0.006 & $(0.01)$ & 0.01 & $(0.01)$ \\
\hline Month fixed effects & Yes & & Yes & & Yes & & Yes & & Yes & \\
\hline District fixed effects & Yes & & Yes & & Yes & & Yes & & Yes & \\
\hline District land use (\%) & No & & No & & No & & No & & No & \\
\hline Pseudo R2 & 0.06 & & 0.06 & & 0.05 & & 0.06 & & 0.06 & \\
\hline No. of observations & 51364 & & 20451 & & 7514 & & 40300 & & 39081 & \\
\hline
\end{tabular}




\section{Appendix 2-12 Rainfall specification}

\begin{tabular}{|c|c|c|c|c|c|c|}
\hline Variables & $\begin{array}{l}\text { Outpatient visits } \\
\text { Marginal effect }\end{array}$ & Std. Err & $z$ & $\begin{array}{l}\text { Inpatient visits } \\
\text { Marginal effect }\end{array}$ & Std. Err & z \\
\hline rainfall & .00003 & .00002 & 1.60 & $1.28 \mathrm{e}-06$ & .00002 & 0.08 \\
\hline Sex & -.02 & .004 & -4.50 & -.001 & .002 & -0.78 \\
\hline Age & .004 & .0002 & 17.83 & .002 & .0001 & 15.20 \\
\hline education & -.013 & .0005 & -26.14 & -.001 & .0003 & -4.84 \\
\hline Sinhalese & .004 & .040 & 0.10 & -.02 & .02 & -1.06 \\
\hline Tamil & -.07 & .04 & -1.67 & -.005 & .02 & -0.24 \\
\hline employed & -.11 & .007 & -16.21 & -.03 & .003 & -10.61 \\
\hline Employer & -.09 & .013 & -6.97 & -.05 & .028 & -3.13 \\
\hline own_family_worker & -.09 & .009 & -9.28 & -.03 & .003 & -9.71 \\
\hline temperature & .0009 & .0006 & 1.46 & $-9.57 e-06$ & .0004 & -0.02 \\
\hline Rural_sec & .04 & .011 & 3.28 & .014 & .006 & 2.51 \\
\hline Estate_sec & .05 & .018 & 3.07 & -.004 & .01 & -0.40 \\
\hline Toilet_own & -.009 & .011 & -0.81 & -.02 & .006 & -4.07 \\
\hline Toilet_public & .012 & .012 & 1.02 & .016 & .008 & 2.06 \\
\hline WaterD_well & -.004 & .011 & -0.32 & .01 & .006 & 2.21 \\
\hline WaterD_other & .003 & .012 & 0.28 & .008 & .006 & 1.37 \\
\hline tota_income & $-1.51 e-08$ & $1.70 \mathrm{e}-08$ & -0.89 & $2.26 \mathrm{e}-09$ & $1.52 \mathrm{e}-08$ & 0.15 \\
\hline hospital_time & -.0003 & .0003 & -0.96 & .00002 & .0002 & 0.09 \\
\hline gov_dispensary_time & -.0003 & .0003 & -0.82 & -.0002 & .0002 & -1.08 \\
\hline private_dispensary_time & .00001 & .0003 & 0.04 & .0001 & .0002 & 0.78 \\
\hline cookF_elect_Gas & -.04 & .06 & -0.65 & -.11 & .03 & -3.57 \\
\hline cookf_other & -.04 & .06 & -0.64 & -.10 & .031 & -3.20 \\
\hline Pseudo R2 & 0.04 & & & 0.03 & & \\
\hline
\end{tabular}


Appendix 2-13: Interaction effect of flood and drought on seeking outpatient health care

\section{Flood*toilet shared}
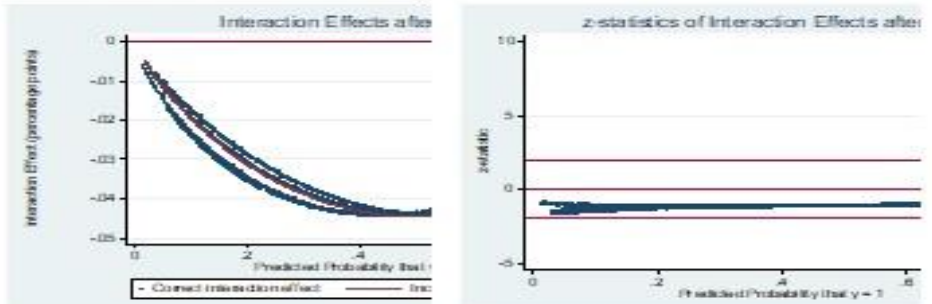

Flood*Drinking water_Well

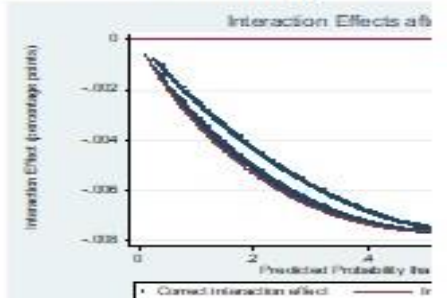

Drought*toilet_shared

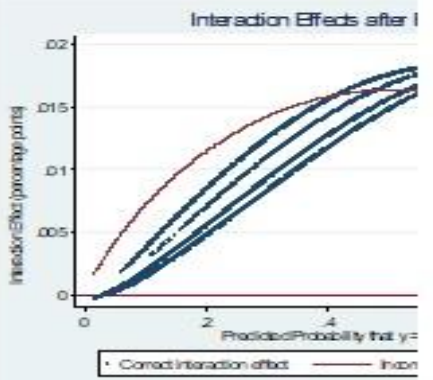

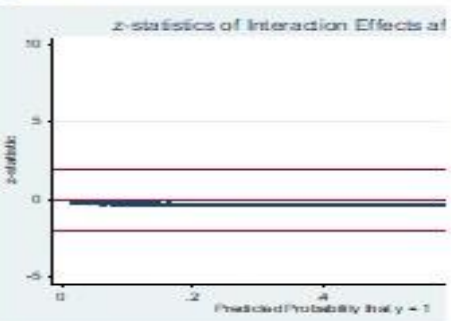

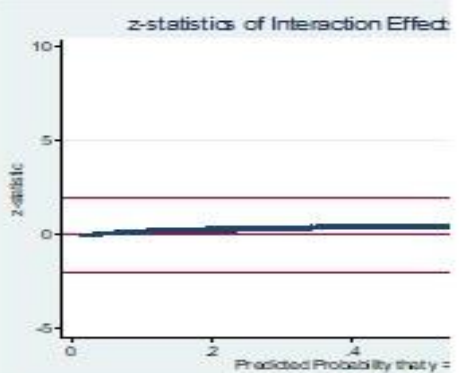

\section{Flood *toilet_public}
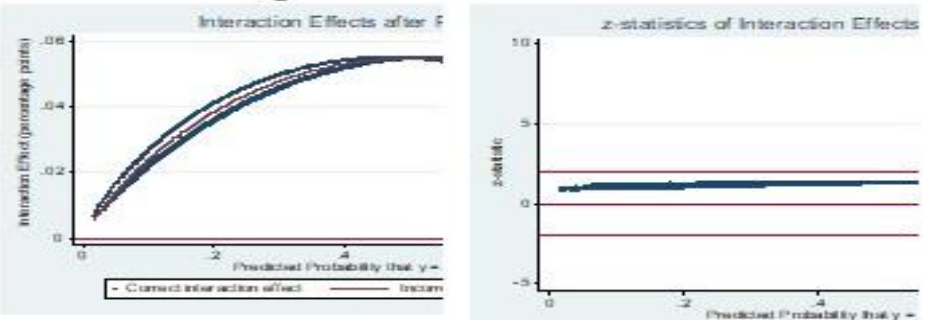

Flood* Drinking water_unsafesource
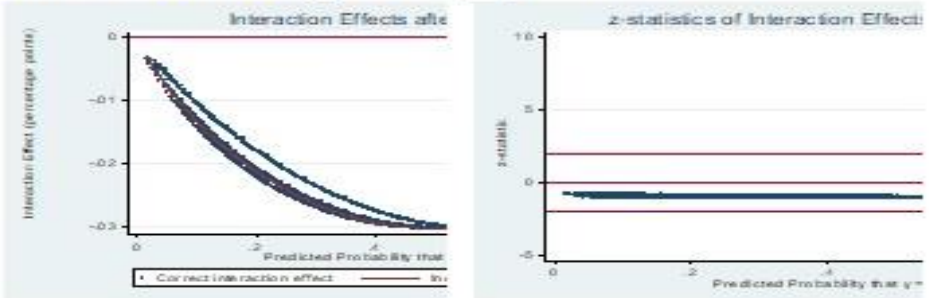

\section{Drought*toilet_Public}
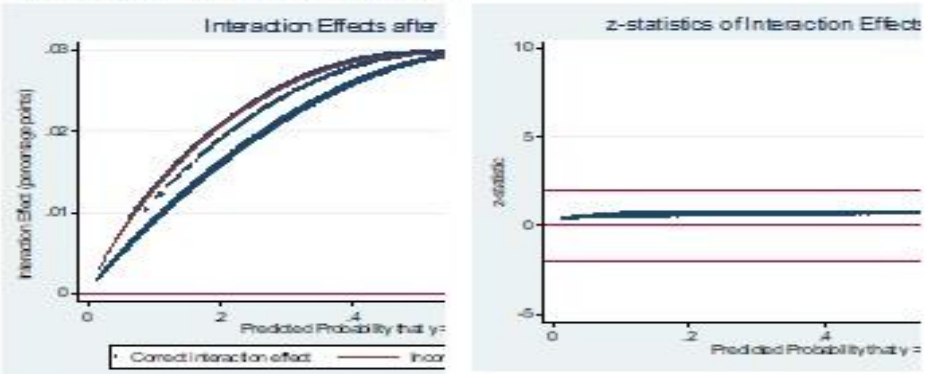
Drought* Drinking water_well

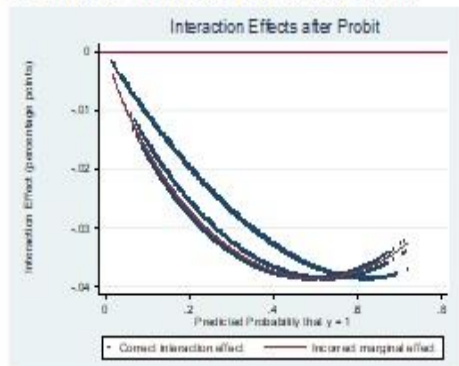

\section{Flood*Rural sector}

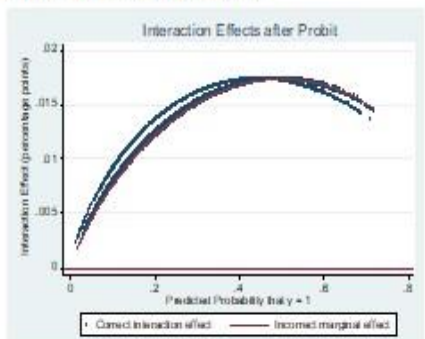

Drought* Rural sector

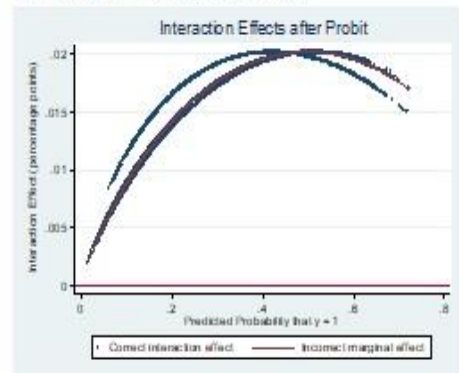

\section{Drought* Drinking Water_unsafesource}
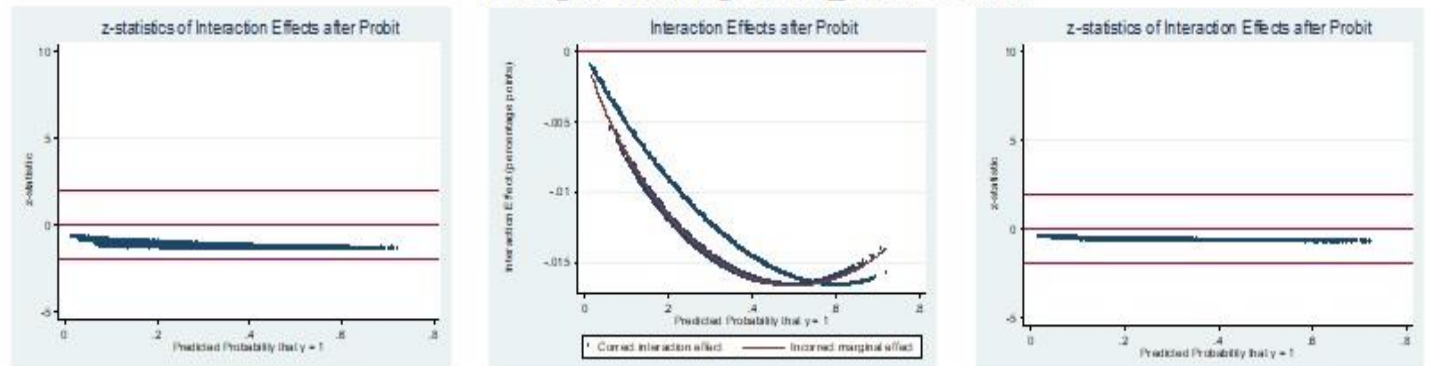

\section{Flood*Urban sector}
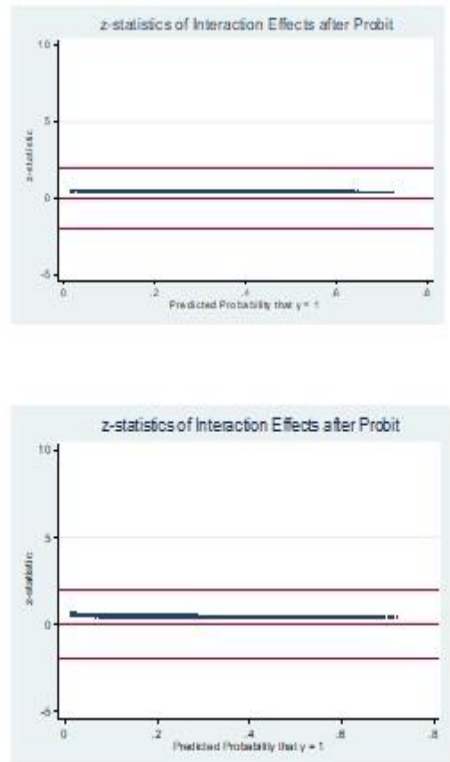

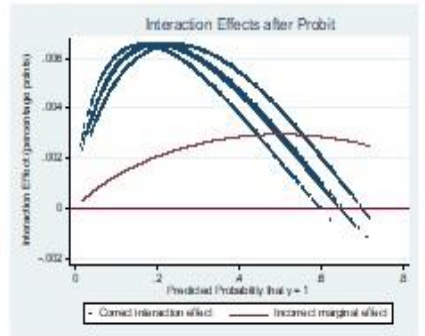

Drought*Urban sector
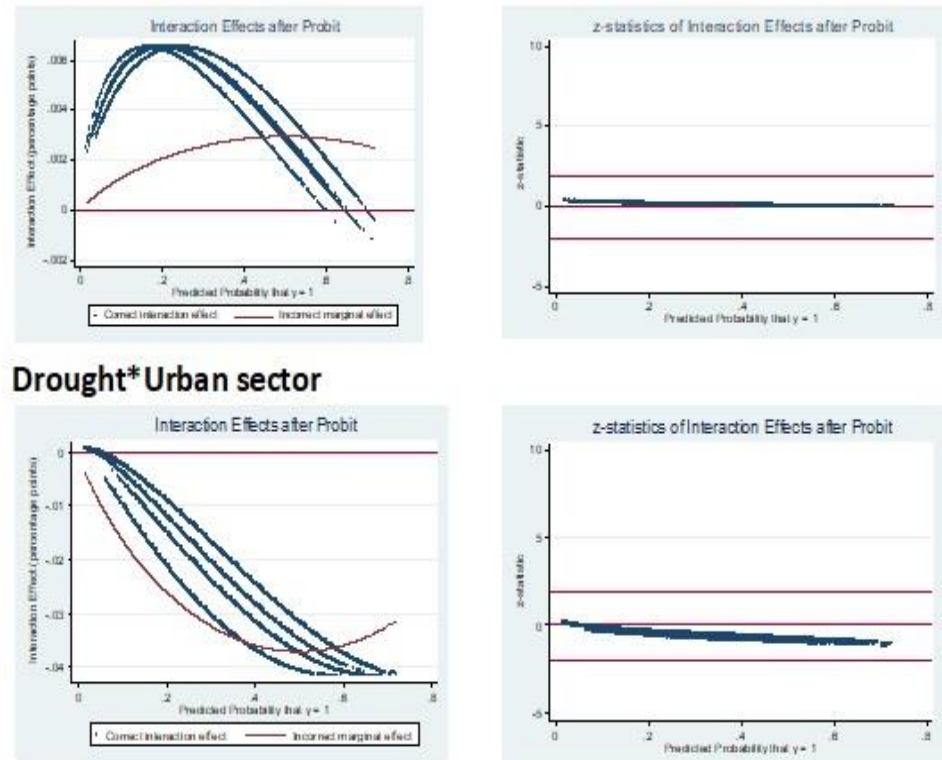
Flood*Child

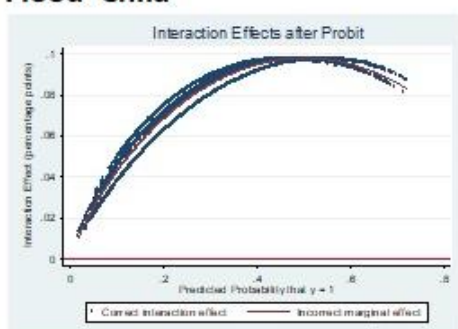

Flood*Middle age

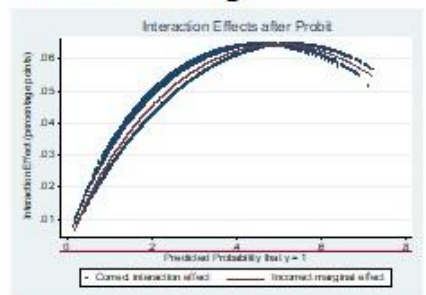

Drought* Child

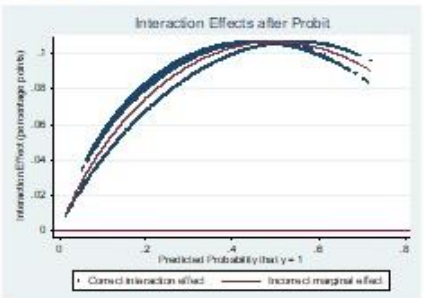

\section{Flood*Youth}
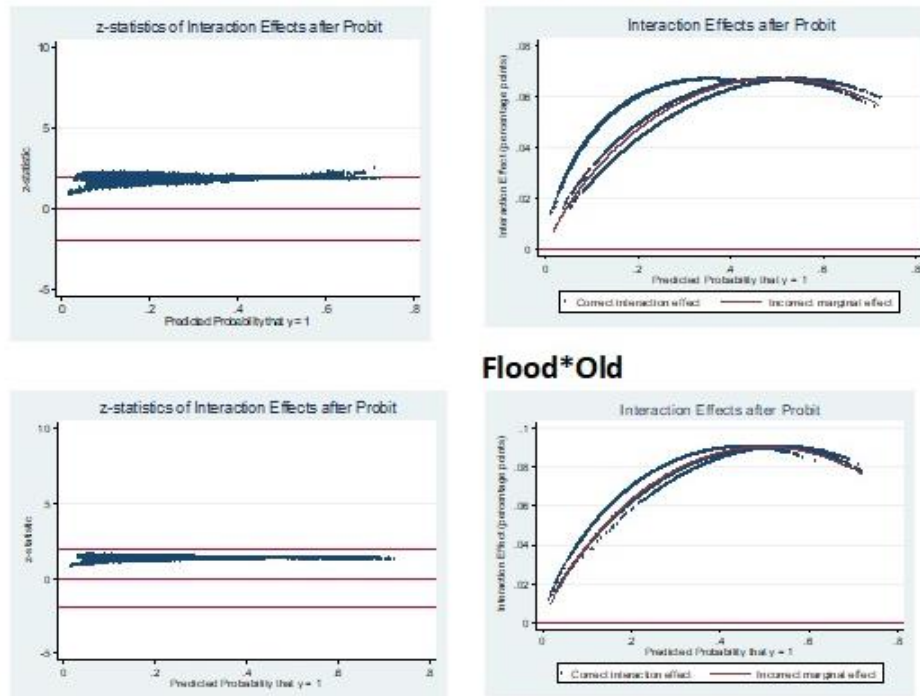

Drought*Youth
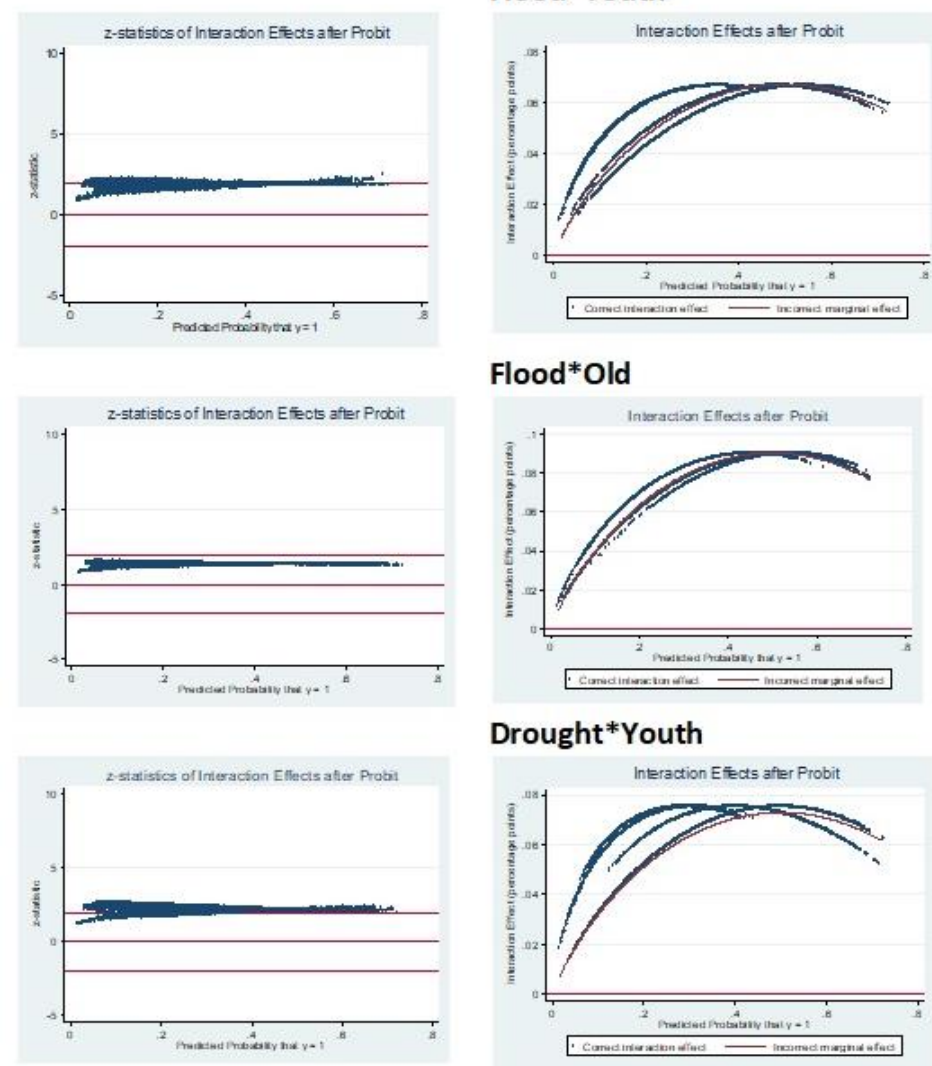

\section{Flood*Old}

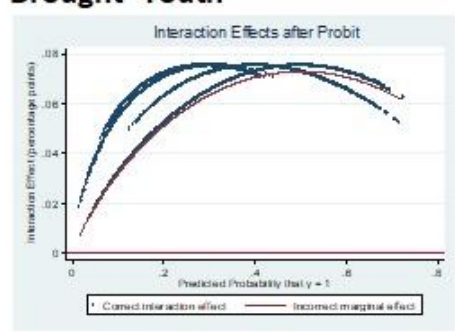

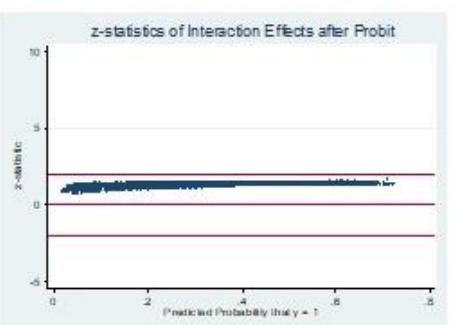
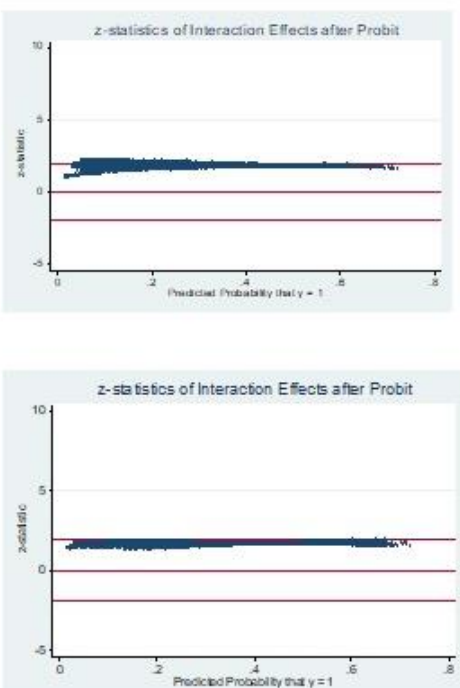


$$
\begin{aligned}
& \bar{C} \\
& \underline{C} \\
& \underline{\underline{C}}
\end{aligned}
$$




\section{Appendix 2-14: Health Care Cost due to Flood and Drought}

Inpatient care Cost if total population is directly affected by Flood

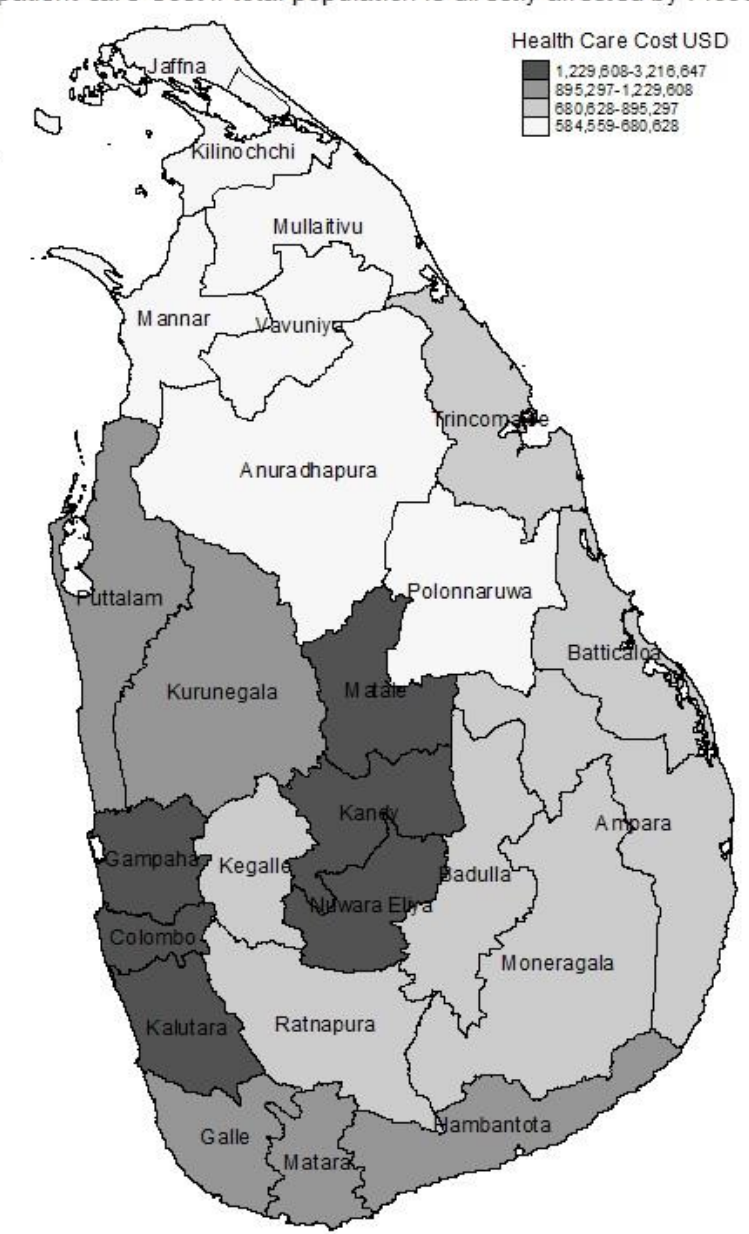

Per Capita Inpatient Care Cost due to Direct Health Effect of Flood

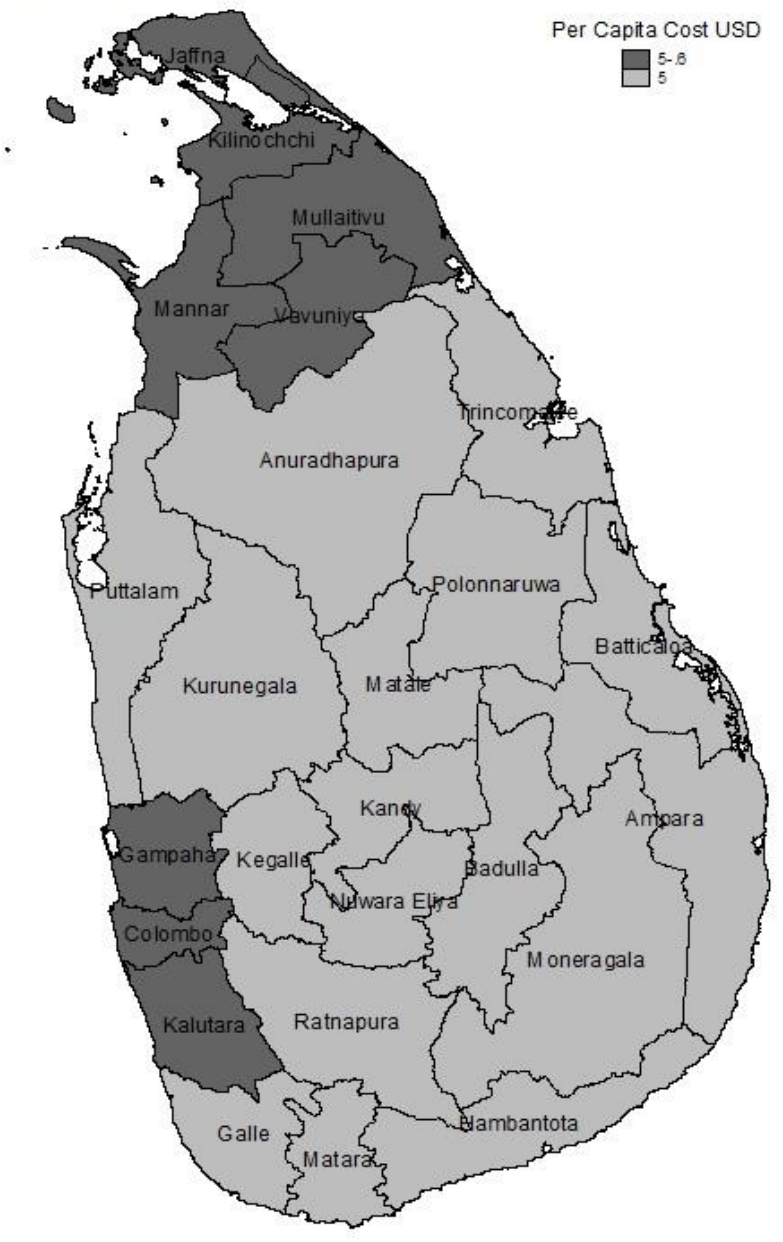


Inpatient care Cost of Flood Spillovers

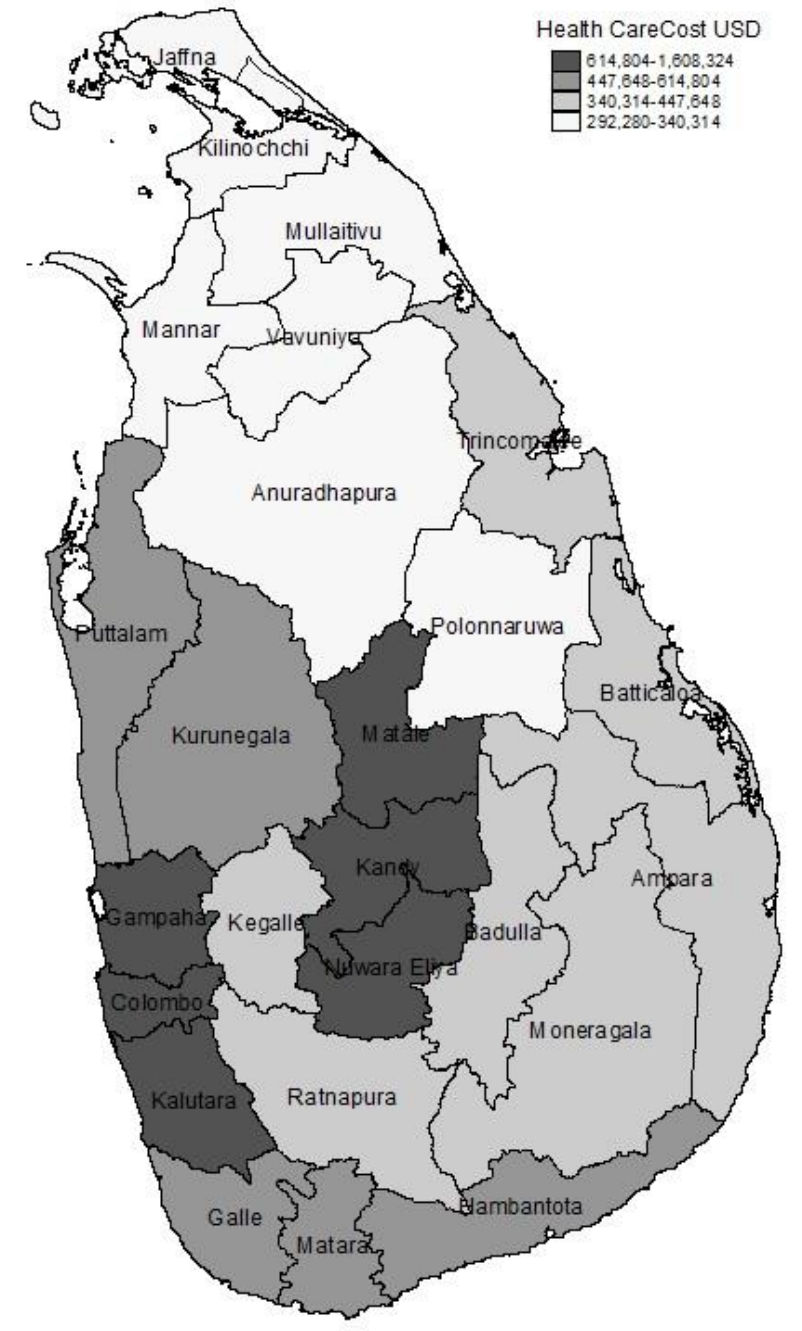

Per Capita Inpatient Care Cost due to Health Spillovers of Flood

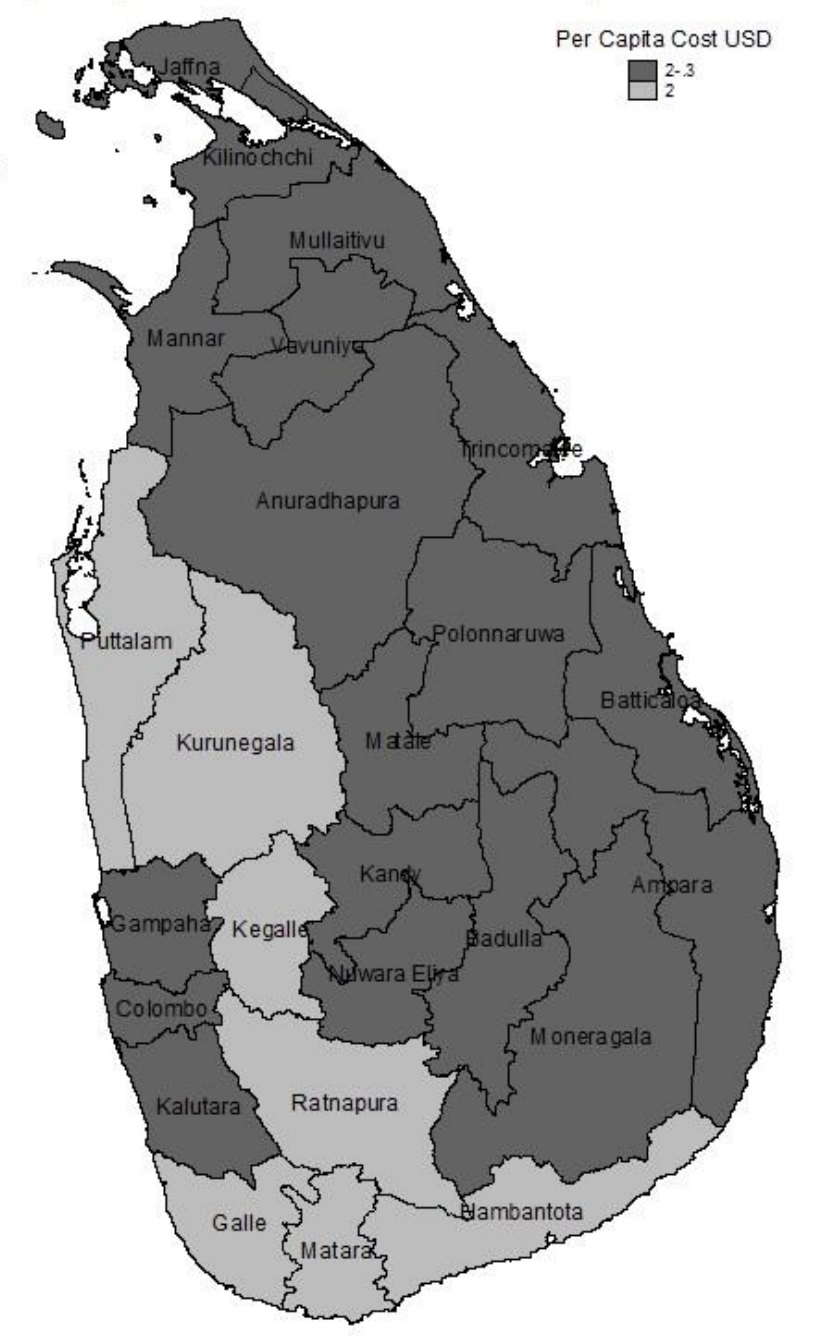


Outpatient care Cost of Drought

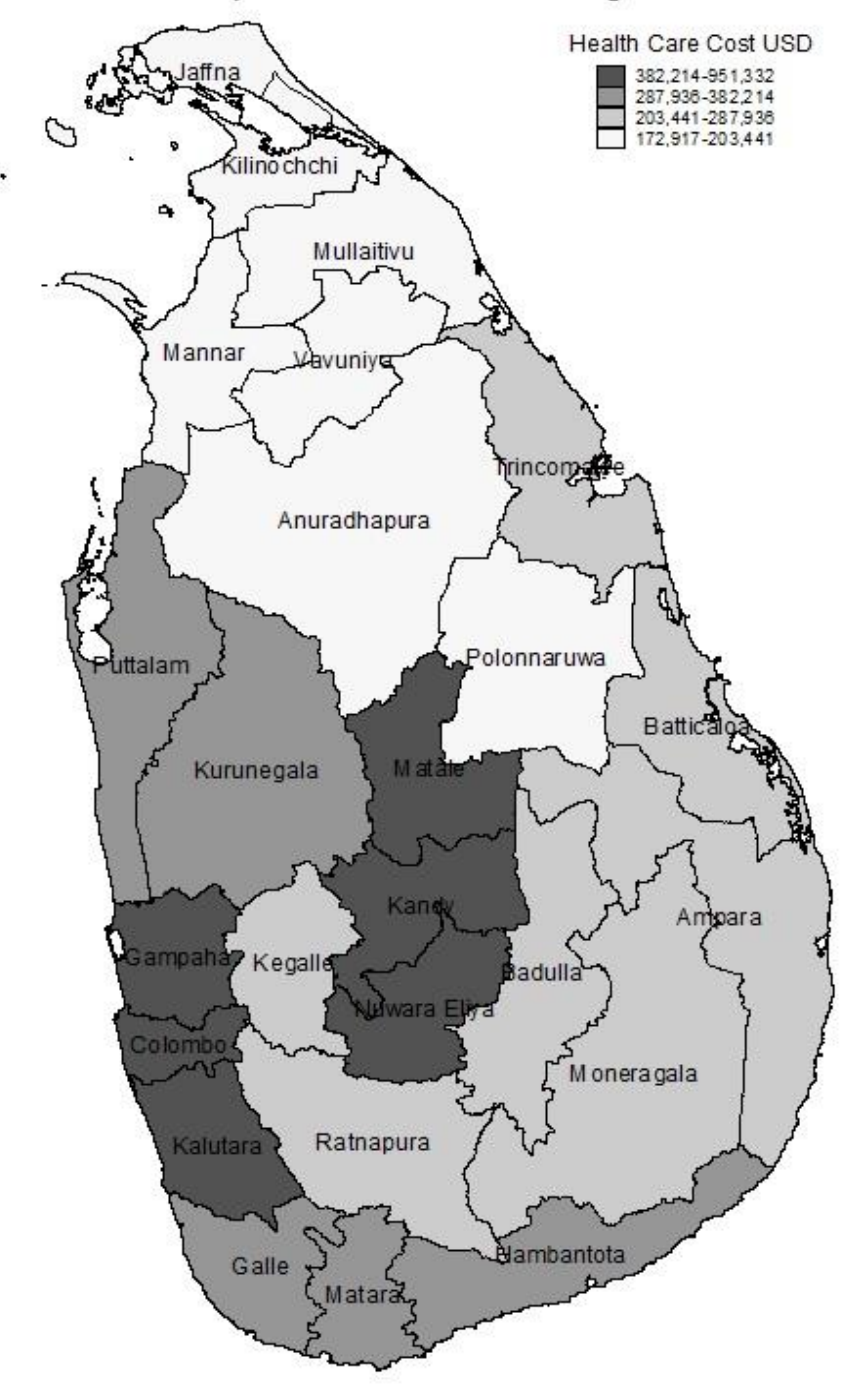

Appendix 2-15: Inpatient and outpatient, private and public health cost

(Percentage of total cost)

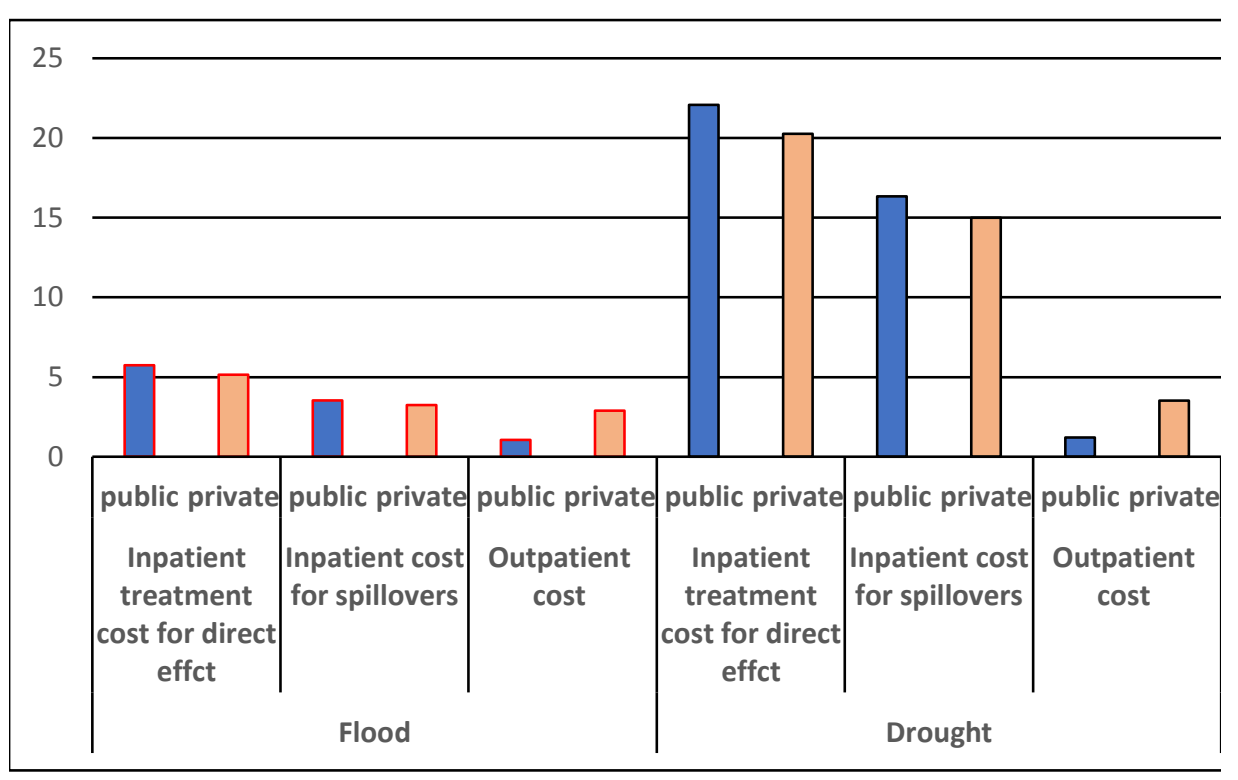




\title{
Chapter Three
}

\section{Sri Lankan Households a Decade after the Indian Ocean Tsunami}

\begin{abstract}
This study estimates the causal effect of the Indian Ocean tsunami in Sri Lanka on household income and consumption eight years after the event, using a Difference-inDifference method. The analysis finds a strong association between area-wide tsunami disaster shock and increases in household income and consumption in the long-term. A more nuanced picture emerges with respect to household consumption impacts. We observe an increase of food consumption and only marginally of non-food consumption. The increase in consumption is much smaller than the observed increase in income. We also find that households in high-income regions experienced a much better recovery from the disaster than those in poorer regions. Deviating from the common observation on short-term impacts, these results are suggestive of a potential for some long-lasting and more successful recovery scenarios. Still, Sri Lanka received a very large amount of external assistance post-tsunami, much larger than is typical for disaster events, and one which may not be replicable.
\end{abstract}




\subsection{Introduction}

The 2004 Indian Ocean earthquake elevated the ocean floor by at least three meters generating a very powerful tsunami that killed about 226,000 and displaced more than 2 million people in around a dozen countries. A large number of casualties and extensive property damage has obvious short-term adverse impacts on economic activity. Relatively less is known about long-term post-catastrophe economic dynamics. ${ }^{13}$ Here, we are interested in households' vulnerability to the long-term impacts of the disaster; specifically, we aim to identify the impact of the tsunami on Sri Lankan households.

In Sri Lanka, the event was completely unexpected and thus undoubtedly exogenous, but its long-term impact was not predetermined. Households' socio-economic characteristics, their exposure and vulnerability to the hazard itself, their resilience and access to tools and mechanisms to manage the disaster's aftermath, their preferences, their decisions when the circumstances around them changed, and their choices during the post-event reconstruction all eventually determined the disaster's long-term consequences (Hallegatte et al, 2014; Hallegatte and Przyluski, 2010; McCarthy and Smith, 2009; Mechler, Linnerooth-Bayer, \& Peppiatt, 2006; World Bank, 2013).

Sri Lanka, an island country in the Indian Ocean, is densely populated, with a 2015 population of 20.7 million (Central Bank, 2015). The population is 74.9\% Sinhalese, 11.2\% Sri Lankan Tamil, 4.1\% Indian Tamil, and 9.3\% Sri Lankan Moor. 20.5\%, 26.3\% and $45 \%$ of the population work in the agriculture, industry and service sectors, respectively (Department of Census and Statistics, 2013). According to the World Bank's classification, Sri Lanka is a lower-middle income country, though social indicators suggest a higher standard of living when compared to other countries in South Asia. From the early 1980s, the country was impacted by an armed uprising; seven districts (out of 25) were intensely affected by the conflict between the government and the Liberation

\footnotetext{
${ }^{13}$ Economic losses - sometime referred to as induced or indirect losses - are considered in terms of changes to flows of goods, services and business or even government revenues. These can emerge in various spatial scales, in different economic sectors, and can change rapidly or evolve slowly over longer periods of time (Rose, 2009; Hallegate \& Przyluski, 2010; Cochrane, 2004, Cavallo and Noy, 2011).
} 
Tigers of Tamil Eelam (LTTE). The armed conflict ended in 2009. Prior to the 2004 tsunami, approximately 25 percent of the population lived in the coastal regions, while 70 percent of tourist hotels and 62 percent of industrial units and almost all fisheries were also located there.

Administratively, Sri Lanka is divided into 9 Provinces, and these are divided further into 25 Districts. Each District is divided into Divisional Secretariats (DS). Each DS consists of several Grama Niladhari (GN) Divisions, the lowest administrative unit. Currently, there are 324 DS Divisions and 14,009 GN Divisions in the country (Department of Census and Statistics, 2015).

The tsunami reached 13 out of the 14 coastal districts, the death toll reached almost 35,500 , and it directly displaced more than one million people. Infrastructure was severely damaged, and the overall direct economic losses totalled USD 1.5 billion, approximately 5\% of the country's GDP (Department of Census and Statistics, 2005). Tourism and fisheries were the two sectors most seriously affected. 150,000 people lost their main income source, $50 \%$ of them were in the fisheries sector. ${ }^{14}$

More than a decade after this catastrophic disaster, we evaluate the long-term householdlevel consequences of this event. The average effect of the tsunami on household income and consumption in the seven affected districts is examined in diff-in-diff experimental setting using cross sectional household data from multiple survey years between 1995 and 2012. Since the intensity of damages-death, displacement and property damage caused by tsunami-vary across districts, the analysis also sheds light on the spatial dynamics of the disaster recovery.

\subsection{Related Literature on Disaster Losses}

\footnotetext{
14 Before 2004, tourism was one of the top income earners in Sri Lanka with gross earnings amounting to USD 416 million during 2004 from peak tourist arrivals of 566,200.
} 


\section{Disaster impact channels}

The large literature on the losses associated with disasters examines consequences at both the micro- and macro-level. Theoretical models (Dacy and Kunreuther, 1969; Okuyama, 2003) suggest that the disastersimpacts on aggregate output are neutral in the long term. In contrast, the 'creative destruction' hypothesis (Benson and Clay, 2004; Skidmore and Toya, 2002; Albala-Bertrand, 1993) posits that one should observe positive economic growth when destroyed capital is replaced with the most recent technological frontier or it shifts to investment in human capital (Hallegatte and Dumas, 2009). At the macro level, the available empirical evidence does not reach any consensus view, but much of the variance in results is a function of the different foci in each paper-the spatial scale, type of disaster, time horizon, etc. Two recent papers provide regression metaanalysis of this literature (Klomp and Valckx, 2014; Lazzaroni and van Bergeijk, 2014).

The macroeconomic modelling literature that incorporates temporal processes (Brookshire et al., 1997; Rose and Guha, 2004; Chang and Miles., 2003; Okuyama et al., 2004; Hallegatte, 2008, 2014; Rose and Wei, 2013; Hallegatte and Vogt-Schilb, 2016) attempts to model various ex-ante factors and ex-post influences and processes into disaster recovery. Spill-over effects of asset losses, externalities associate with damaged public goods, stimulus effect of disaster reconstruction, and the productivity spill overs associate with build back better reconstruction are the widely discussed channels of economic impacts in the literature.

The spillover effects associate with disasters can span into the long-term and to those who were not directly affected by the disaster (Noy and Patel, 2014). Such effects of catastrophic disasters are possible, for example, through damages to lifeline infrastructure services, business, and employment interruptions. Delays in Infrastructure restoration can be a significant barrier to businesses re-opening and therefore to longterm recovery (Webb et al. 2000, 2002; Lam et al. 2009). The empirical literature argues that pre-disaster trends of decline are often accelerated, exacerbated, or intensified in recovery (Chang, 2000; Alesch, Arendt and Holly, 2009; Chang, 2010). In contrast, industries filling important niches required in the aftermath of disaster - services 
previously not available but needed for reconstruction - grow in the post-disaster period (Rose and Szelazek, 2011), but such economic stimulus is observed in developing economies and the positive impact may be temporary (Dacy and Kunreuther 1969; Chang, 2010).

Reconstruction after disaster can generate longer-term benefits if the damaged capital is replaced with better technology (Hallegatte and Dumas, 2009; Cauresma, Hloušková and Obersteiner, 2008; Hornbeck and Keniston, 2014). More generally, catastrophic events can cause persistent structural change in local economies where the post-disaster differ from the pre-disaster economy (Alesch, Arendt and Holly, 2009; Lam et al. 2009; Chang 2010). Such reconstruction depends on characteristics of the reconstruction and the affected economy - level of capital destruction, ex-ante risk transfer arrangements, financial strength of public sector and its ability to access financial resources, recovery policy decisions, and capacity of sectors involve in reconstruction process (Chang and Miles, 2003; Hallegatte and Vogt-Schilb, 2016).

No comprehensive framework or model of disaster recovery currently exists and the empirical literature provides few details about the causal channels that lead from the hazard trigger event itself to the macroeconomic aggregate impacts that are identified (be they on aggregate income, employment or unemployment, production, or fiscal and trade deficits). The micro-econometric literature may be better able to unveil these causal chains from the triggering event to its impacts, and hence we focus on these.

\section{Empirical evidence: household risk management}

Households manage the risk they are exposed to because of natural hazards through several risk transfer and risk management tools. First, coping with risk can occur through income smoothing: making conservative production or employment choices and diversifying economic activities. In this way, households take steps to protect themselves from adverse income shocks before they occur. Second, households can smooth consumption by borrowing and saving, depleting and accumulating nonfinancial assets, adjusting labour supply, and employing formal and informal insurance arrangements. 
Explicit insurance contracts and credit are the primary market-based arrangements available to manage financial risks, but these were not at all common before 2004 to the affected households. In Sri Lanka, implicit insurance arrangements (from kin, from governments, or from the international community) also play a role in transferring risk away from affected households. ${ }^{15}$ Similarly for firms, the access to resources appears to play a central role in post-disaster recovery. ${ }^{16}$

The literature suggests that low-income households are credit constrained and their ability to self-insure is limited. This results in variation in expenditures associated with realized risks (Mogues, 2011; Baez and Mason, 2008; Carter et al., 2007; Baez, 2006; Jansen and Carter, 2013). Because of inadequate risk transfer, poor households use costly ways to confront risk, ways that may have long-lasting adverse consequences. These consequences can be especially severe for the poorest households (Dercon and Christiaensen, 2011; Dercon, Hoddinott and Woldehanna, 2007).

Households accumulate saving to cushion the welfare loss. Evidence suggests that household saving is higher in countries with greater risk exposure and frequency of intense disasters (Aizenman and Noy, 2015; Skidmore, 2001). When productive assets are lost due to disaster, households may need to reduce consumption to protect their remaining assets (Barrett et al., 2007; Kazianga and Udry, 2006; Little et al., 2006). Either way, they can fall into "poverty traps" from which recovery is difficult without external assistance. Carter and Barrett (2006), for example, provide evidence for such 'asset poverty traps' among pastoralists in northern Kenya.

\footnotetext{
15 Sawada and Shimizutani (2007), for example, observe that the households with collateral and free from binding borrowing constraints were better able to cope with income loss following the 1995 Kobe earthquake. With limited access to explicit risk transfer financial instruments, the poor respond to shocks by pooling risk through social mechanisms such as credit cooperatives and mutual assistance pools (Baez, 2006; Little et al, 2006; World Bank, 2013).

16 Following the tsunami, Sri Lankan firms with access to loans or grants performed better (De Mel et al., 2011); in New Zealand, insured firms performed better than un-insured ones following a large earthquake (Poontirakul et al., 2017).
} 
Reductions in household consumption can have significant adverse consequences to well-being, including even reduced height and body mass index for children experiencing these events (Alderman, Hoddinot and Kinsey, 2006; Hoddinot, 2006). In cross-country analysis, Cuaresma (2009) identifies a strong negative correlation between disasters and secondary school enrolment while Cruso and Miller (2015) investigate a destructive 1970 earthquake in Peru and show a relative deficit in education and labour outcomes even several decades later. More worrying, they showed that even children whose mothers were affected at birth, and were thus born a full generation later, still attained fewer years of schooling.

For middle- and low-income countries, foreign assistance (from whatever source) may potentially provide the necessary financial resources to pay for post-disaster recovery. However, the evidence seems to suggest that much of disbursed emergency (postdisaster) aid is guided by geo-strategic concerns and not by the disaster itself, is not very well-targeted to vulnerable populations, and in any case, is not very large - see Fleck and Kilby (2010), Francken et al. (2012), and Becerra, Cavallo and Noy, (2014), respectively identifying these characteristics of post-disaster aid.

There is little research on the impact of post-disaster aid, but some of the available evidence about the post-tsunami aid, specifically, suggests that it was not necessarily targeted to those who were most affected by the disaster (e.g., Aldrich, 2010; Becchetti and Castriota, 2011). In general, it is very difficult to rigorously establish the causal impact of foreign aid, even more so for post-catastrophe foreign aid.

When formal insurance or other safety nets such as aid are not available, the poor diversify their income sources to lower risk exposure. Typically, this may be done either through labour sector diversification locally or through emigration. Coffman and Noy (2012), and Lynham, Noy and Page (2017) observe people migrating away after a hurricane in 1992 and a tsunami in 1960 in Hawaii, respectively. For the 2004 Indian 
Ocean tsunami that is the focus of this paper, Brata, Henri, Groot and Rietveld (2014) identify only a temporary change in the spatial distribution of population in Indonesia. ${ }^{17}$

Research shows that remittances play an important role in the household's reactions to disasters (Deshingkar and Aheeyarse 2006; Savage and Harvey, 2007; Mohapatra, Joseph and Ratha, et al., 2009). Suleri and Savage (2006), for instance, observe that households receiving remittances were able to recover faster from the 2005 Afghanistan earthquake. Gröger and Zylberberg (2015) observe rural households in Vietnam sending members to urban areas in the aftermath of the 2009 catastrophic typhoon, and households with settled migrants receiving more remittances in the typhoon's aftermath. Le de, Guillard and Friesen (2015) observe an unequal access to remittances, with the poor having less access and therefore struggling more to recover from the 2012 cyclone in Samoa.

Individual time and risk preferences have important implications for risk coping and economic outcomes (Quddas, Goldsby, Farooque, 2000). When exposed to traumatic disasters, affected people could exhibit more risk averse behaviour. Cameron and Shah (2011)'s experiment using risk games, in Indonesia, shows more risk averse behaviour among individuals that suffered from flood or earthquake. After the Chile 2010 earthquake, Fleming, Chong and Bejarano (2011) find overall decline in trust behaviour but no difference between affected and not affected individuals. Huang, Bao, Chen and Bi (2011) observe increase in public seismic risk acceptance after the Wenchuan and Yushu earthquakes in China. In Thailand, five years after the 2004 Indian Ocean tsunami, Cassar, Healy and Kessler (2011) find individuals are more trusting, risk averse and change their time preference. Callen (2012) finds opposite evidence from Sri Lanka two and half years after the 2004 Tsunami; affected wage workers are more patient, and experiencing the event appear to substitute for other inputs to preference formation such as education. Seven years after the Tsunami in Sri Lanka, Becchetti, Castriota and Conzo (2012) observe less pro-social attitude of individuals.

\footnotetext{
17 This temporary effect may be due to the strong positive influence of the disaster on the peace deal between the Government of Indonesia and the Free Aceh movement in 2005. Halliday (2012) reveals people migrating away after an earthquake in El Salvador.
} 


\section{Contribution}

In here, we are able to describe the dynamics experienced by tsunami-affected households in the decade following the event itself. Our main contribution in this paper is the focus on the long-term impacts of the event, while most of the previous literature cited above focuses on very short-term impacts at most a couple of years. In contrast with most studies using micro identification, our empirical micro household estimations, using area wide treatment measure capture not only ex-post reaction and effect of tsunami on affected households, but also reflect indirect local spill overs and ex-ante and ex-post preparedness to this catastrophic event.

\subsection{The Aftermath of the 2004 Tsunami in Sri Lanka}

In the immediate aftermath of the 2004 catastrophe, the government established the Centre for National Operations with special powers to oversee the coordination of agencies involved in rescue and relief. Three task-forces were established: (1) The Task Force for Rescue and relief; (2) The Task Force for Logistics, Law and Order; and (3) the Task Force for Rebuilding the Nation (Government of Sri Lanka, 2005). The Ministry of Finance set up a coordination system with national agencies, donor agencies, and international non-governmental organisations, to support 16 primary interventions or activities identified as priorities. Eventually, the coordination and facilitation roles were transferred to a newly formed Reconstruction and Development Agency. Reconstruction activities were coordinated at District and Division level by the government representative at each level (Joint Report of GOSL and Development Partners, 2005).

Initially, the government declared a development-free buffer zone along the coast in which reconstruction was restricted, but in 2005 this policy was abandoned due to strong opposition from the public (Ingram et al., 2006). New houses were provided based on proven ownership claims for destroyed houses or, alternatively for those unable to document land ownership, through a donor-driven program. For completely damaged houses, the government provided land, cash grants, and additional donor assistance to 
rebuild houses. Financing for tsunami reconstruction in Sri Lanka relied mainly on foreign funding. The government of Sri Lanka initially estimated 2.0 billion including an ambitious build back long term reconstruction program (GOSL, 2005). Almost 1.4 billion were spent on reconstruction by the end of 2006 - two years after the tsunami (Jayasuriya and McCawley, 2010). Later, the tsunami reconstruction was managed within the government's standard development program. As elsewhere, reconstruction faced problems of coordination, escalation of construction costs, and other similarly common difficulties in post-disaster recoveries (Athukorala, 2012; Jayasuriya and McCawley, 2010; Munasinghe et al., 2007).

\subsection{Empirical Analysis of Household Survey}

This study isolates the causal effect of the 2004 tsunami in a quasi-experimental analysis using pooled cross-sections of information from household surveys. We include observations of 84,393 households obtained in five Household Income and Expenditure Survey waves conducted in 1995, 2002, 2006, 2009 and 2012 by the Sri Lanka Department of Census and Statistics. The longitudinal nature and richness of household level information covering nearly a decade before and a decade after the tsunami make these surveys well suited to investigate the tsunami's long-term impact at the household level.

The surveys collected detailed information on household and individual demographics, employment, consumption, income and other related data corresponding to the preceding calendar year. The demographic characteristics include variables such as sex, age, marital status, ethnicity, religion, level of education, employment status, and house ownership. Household consumption expenditure include household food consumption expenditure (including value of in-kind consumption), household non-food expenditure (household expenditure on housing, education, health, transport, and recreation), household expenditure on durables and on insurance and savings. Household income is composed of the income from paid employments, net income of the household from nonagricultural and agricultural activities, cash receipts (pension, disability and relief, food 
stamp, property rent, dividends), and remittances (from abroad and from within the country).

Due to the civil conflict that ended in 2009, data for eight conflict-ridden districts are not available before the end of the conflict. Thus, survey data for 17 Districts from 1995 to 2013 were used in the analysis. Details about the data available in each wave of the household survey and their definitions are available in Appendix Table 3-1. The summary statistics are available in Table 3-1. The composition of ethnic and religious groups, and composition of households according to their location (urban, rural, estate) in the survey sample are all comparable approximately to the national figures available from the census, and the sample was collected to be nationally representative.

To isolate the causal effect of the disaster precisely, randomised experimentation is ideal, and a (time-series) panel of households would be preferable. Since randomised experimentation is impossible and panel data are unavailable, we instead use crosssectional data pre- and post-disaster in a quasi-experimental analysis. The identification strategy relies on the standard common trend assumption in difference-in-difference estimations, and we show that this assumption appears appropriate in this case.

To identify the treatment group, we exploit the spatial variation of tsunami damage using reported deaths, displacements, homelessness and infrastructure damage (replacement cost) due to tsunami across districts. Our aim is to reveal the average causal effect from the area-wide tsunami shock. Out of 25 Districts, 13 Districts were affected by the tsunami (Appendix Table 3-2) and all reported mortality rates, the number of people displaced, the number of people that became homeless, and the damage to public infrastructure. Out of the 13 affected districts, the surveys covered only seven districts both before and after the tsunami, as the other six districts were directly involved in the conflict. Our treatment group comprises the households in the affected seven districts for which we have data.

In the absence of household level reported tsunami damage, we first estimate the average effect for all households in the affected districts. However, the exposure of the districts 
and the households in those districts to the tsunami varied considerably. The regions on the eastern and southern coasts were directly exposed to the tsunami waves coming from east-south-east, the waves were much higher, and more damage was reported in those districts. We also exploit the damage information available across districts and at the subadministrative units in each affected district to examine how recovery vary when accounting for the level of damage. GN division is the smallest administrative unit and DS is larger than GN and lower than the District-level administrative unit which is the unit of observation in our regressions. We define five damage intensity variables: (i) number of affected GN divisions divided by the total number of GN divisions in respective District, (ii) population in destroyed and damaged houses in each district divided by the total population in each affected district, (iii) population in the affected DS divisions in each district divided by the total population in each respective district, (iv) total deaths in each district divided by district population and ( $\mathrm{v}$ ) displaced population in each district divided by the district population.

We estimate the impact using the variation of intensity measures as robustness checks of our average treatment effect on treated households (ATE). Further, separate models are estimated for high intensity and low intensity districts that are defined using different intensity measures - i.e., intensity measure (iii) and all five intensity measures in combination (treatment groups identified using figure 3-3 in the appendix). ${ }^{18}$

The previous literature argued that the long-term impacts vary with the vulnerability of the affected households (e.g., Noy and duPont, 2016). To examine the impact of vulnerability on recovery, we estimate separate models for treatment groups excluding the two richest districts (Colombo and Gampaha) and treatment group including only the two richest districts.

\footnotetext{
${ }^{18}$ We chose measure (iii) because among all five intensity measures, it potentially captures the intensity better by the DS level measures than the ones based on the GN level. One reason is that public investment decisions are made up to the DS divisions level targeting the population in each DS unit, and those investments are meant to provide benefits beyond GN level. Secondly, this catastrophic disaster destroyed a lot of public infrastructure (see online appendix table 2) other than the deaths, displacements, and destruction of houses, affecting people who use this infrastructure but live beyond the immediately affected GN divisions.
} 
Our identification uses difference-in-difference (DID) method. The standard empirical specification is:

$Y_{i d t}=\beta_{1}+\beta_{2}$ Post $_{i}+\beta_{3} T_{d}+\beta_{4}$ Post $_{i} T_{d}+U_{\text {idt }}$

Modifying the standard model, our empirical specification takes the following form:

$Y_{i d t}=\beta_{1}+\beta_{2}$ Post $_{i} T_{d}+\beta_{3} \delta_{t}+\beta_{4} X_{i d t}+\beta_{5} \gamma_{d}+U_{i d t}$

$Y_{i d t}$ is the outcomes of interest (household monthly consumption and household monthly income). The unit observed is household $i$, in district $d$ and time $t . T_{d}$ is the treatment dummy defining membership in the treatment cross section (affected $=1$, not affected $=0$ ) and $U_{i d t}$ are the unobserved affects. Post $t_{i}$ is a dummy variable to distinguish sample by pre- and post-treatment. $\beta_{2}$ is the treatment effect of interest.

Other than the common trend assumption, treatment exogeneity is key for unbiased estimation. Treatment effects are naturally heterogeneous across households depending on household characteristics and the community level characteristics that they live in. By adequately controlling for such heterogeneity, the unobserved variation should account for the average treatment effect on treated households (ATE). Household demographic and socio-economic covariates $X_{i d t}$ are incorporated into the model to control for household heterogeneity. Gender, age (years), years of education, ethnicity of household head, and household size are all used in the model estimation, as well as year fixed effects $\left(\delta_{t}\right)$. The geographic differences are controlled by district fixed effects $\left(\gamma_{d}\right)$. Finally, the other differential effects and the mean of the error term $U_{i d t}$ are assumed zero.

To evaluate the robustness of our estimated model using standard specification, we also estimated a more flexible model incorporating (i) district-specific linear time trends, (ii) district-specific quadratic time trend (in square brackets in the following equation) and (iii) coastal and non-coastal region specific linear time trends. The revised specification is:

$Y_{i d t}=\beta_{1}+\beta_{2}$ Post $_{i} T_{d}+\beta_{3} \delta_{t}+\beta_{4} X_{i d t}+\beta_{5} \gamma_{d}+\left[\beta_{6} \gamma_{d} * t+\beta_{7} \gamma_{d} * t^{2}\right]+U_{i d t}$

In a different set of regressions, instead of dummy variable for treatment as in the previous model (eq. 2), we introduce treatment indices $\left(T_{d}^{\text {ind }}\right.$ ) into the model.

$Y_{i d t}=\beta_{1}+\beta_{2} T_{d}^{i n d}+\delta_{t}+X_{i d t}+\gamma_{d}+U_{i d t}$ 
The models are estimated for defined five treatment indices as detailed earlier and using Ordinary Least Squares estimation. Since heteroscedasticity and serial correlation may be present in the data, we use robust and district-clustered standard errors for inferences. The cluster-robust standard errors could be under estimated given the small number of districts in Sri Lanka, so we also use wild bootstrap estimation.

\subsection{Results}

Table 3-1 provides some descriptive statistics of this data. In total, $64 \%$ of the 84,393 complete records of households are in the years following the tsunami, while $51 \%$ of the households live in the districts affected by the tsunami.

\subsubsection{Income}

Table 3-2 presents our benchmark results for household income. We observe the average treatment (tsunami) effect on treated (ATE) household income by examining the coefficient ( $\beta_{2}$ in equation 2 ) for the interaction of the treatment indicator (tsunamiaffected district) and post-tsunami year. Presented are several estimations based on different assumptions regarding the standard errors, and the inclusion of covariates, district fixed effects, and district-specific linear or quadratic time trends. ${ }^{19}$

Column I provides the basic estimates without year fixed-effects or additional controls. Column II controls for household heterogeneity; and district fixed-effects are included in column III. Qualitatively, these differences do not have much impact on the main variable of interest, but the inclusion of fixed-effects does reduce the size of the estimated ATE coefficients, suggesting that some of the observed ATE in column II is an over estimation associated with the higher income in the coastal districts. Column III is our preferred specification as it includes district districts fixed effects. For further verification of

\footnotetext{
${ }^{19}$ In alternative estimations, we include several additional covariates. The details about these, and the regression results for the two dependent variables - income and consumption - with these covariates, are provided in the online appendix.
} 
whether observed treatment effect could be due to the treatment district's specific time trends rather than the treatment itself, in column IV we include a linear district-specific time trend, while in column $\mathrm{V}$ we include a quadratic variation of this time trend. We estimated the model adding coastal and non-coastal specific linear time tend to the specification IV to account for treatment and control group specific time trends; estimated are not significantly different from model IV. ${ }^{20}$ The inclusion of these time trends does not have much impact on the estimated coefficients of interest, so we conclude that indeed the magnitudes presented in columns III-V for the disaster impact appear robust. ${ }^{21}$

Generally, in table 3-2, we find that incomes went up for households in tsunami affected districts, with large increase in 2006, and more moderate increase in 2009 (implying a decline in income between 2006 and 2009), but a further increase in 2012, potentially boosted by the end of the conflict; an end that allowed the investment that occurred posttsunami in the coastal districts to bear fruit and increase returns. Income increased due to the tsunami in the year 2006 by Rs. 7048 (49 US\$), slightly reduced in the year 2009 (Rs. 5870, 40 US\$) and increased significantly in the year 2012 by Rs. 15142 (104 US\$). We also estimate these effects for each of the affected districts separately (by including district-year fixed effects). All 7 districts indeed show an increase in income posttsunami, and for 6 out of the 7 affected districts we observe (in the figure 4) the same pattern of a tampering of the effect in 2009, and a dramatic increase in 2012 (relative to the unaffected districts in the control group).

Wider gap between non-normalised average income between treatment and control group in figure 3-1 and much variation in the non-normalised average income across districtes in figure 3-2 justify the need to control for heterogeneity in our empirical

\footnotetext{
${ }^{20}$ Impact of SLR 7006with statistical significant at 5\%, SLR 5763 statistically significant at 5\%, and SLR 15137 statistically significant at 1\% respectively for year 2006, 2009 and 2012.

21 The results are robust at 5\% or $10 \%$ with wild bootsrap standard errors. The wild bootsrap 95\% confidence interval for null hypothesis imposed for treatment effect in each post year is given in square bracket and $\mathrm{p}$ value in the row below.
} 
model. After accounting for such heterogeneity in our model, the parallel trend between control and treatment group in the pre-treatment period and the effect of treatment posttreatment are clearly seen in the normalized income in the figure $3-3.22$

In the online appendix figure 3-4, we present the non-normalised average incomes across districts and over time averaged separately for high-, middle-, and low-damage districts and the districts that suffered no tsunami damage. It is easily seen that while income is flat for the control districts, the pattern of moderate increases in income in the 2006 survey, and much more dramatic increase in the 2012 survey is observed in the simple averages for all damage groups (low, middle and high) with the most dramatic increase for the middle-damage districts. This figure also confirms the parallel trends between treatment and control pre-tsunami - one of the assumptions of a diff-and-diff methodology. The divergence of the treatment and control lines in figure 3-2 and in the non-normalized data (in the appendix figure 3-4) post-tsunami starkly demonstrates our finding: households residing in tsunami affected districts experienced an increase in income in the post-tsunami years relative to the unaffected districts. We find that our results appear robust to the presence of limited number of clusters in our sample.

In table 3-3, we describe the ATE of the tsunami on the various sources of household income. In particular, we separately examine the ATE for paid income, agricultural and non-agricultural income, remittances, transfers, dividends, and rents (and other income). Considering the significant district-specific time trends revealed in model specification IV in table 3-2 (full regression results are available in appendix 3-12), we estimate these using the same specifications with district-specific time trend. In non-agricultural income sources, the identified ATE for the three post-tsunami years is positive, and also the most statistically significant: in 2006 by Rs. 6934 (53 USD), in 2009 by Rs. 7242 (55.7 USD) and 2012 by Rs. 10675 (82 USD). We find the same pattern of an increase in paid income in

\footnotetext{
22 The normalized income observations are the predicted residuals after regressing income against household covariates and district fixed effects and collapsed by mean and survey years for both control and treatment groups). These full regression results are available in the online appendix table 3-12.
} 
2006, a smaller increase in 2009, and a much larger increase in 2012. The largest increase in 2012 is both statistically significant and positive.

It is interesting to note that agricultural income is reduced significantly. Agriculture in Sri Lanka is still a very important source of economic activity, and this result is doubly surprising as previous research on flood disasters concluded that in the short-term, riverine floods can increase income from agricultural activities (as the productivity of flooded land increases post-flood). In this case, of course, a tsunami or a cyclonic storm surge damages the land through increases in salinity, rather than increases its fertility. These results therefore align more with our expectations about the specific details of this catastrophic event.

\subsubsection{Consumption}

Tables 3-4, 3-5 and 3-6 include the detailed estimation of the impact of the tsunami on household consumption and its components, respectively. As discussed above with respect to income, our specification in column III of table 3-4, includes the household covariates and the district fixed-effects, and is estimated with district clustered standard errors. Columns IV and V include district-specific time trends (linear and quadratic, respectively), but results in these specifications are very similar to the results in column III, with respect to the estimation of the ATE. Estimates incorporating costal and noncoastal linear time trend in IV are similar except little addition to year 2012.23 The ATE revealed in the model with district specific quadratic time trend shows a marginallysignificant impact in year 2012. In column III and IV of table $3-4,{ }^{24}$ the estimated ATE for consumption is positive in all the three survey years post tsunami but is not statistically significant for the 2009 observation. As was the case for income, the impact in the longer term (2012) is larger than the impact in the immediate aftermath (in this case more than

\footnotetext{
${ }^{23}$ Impacts of SLR 1324 with statistical significance at 10\%, SLR 303 but statistically non-significant and SLR 3068 statistically significant at 1\% respectively for year 2006, 2009 and 2012.

24 The results are significant at either $5 \%$ or $10 \%$ considering wild bootsrap standard errors. The wild bootsrap $95 \%$ confidence interval for null hypothesis imposed for treatment effect in each post year is given in square bracket and $p$ value in the row below.
} 
twice as large). Importantly, however, the positive observed increase in consumption is much smaller than the increase we previously identified in household income. It appears that the increase in income does not translate very well into increases in wellbeing as measured by the consumption items considered in the analysis. ${ }^{25}$

The non-normalised consumption across treated and control groups and across districts are presented respectively in figure 3-5 and 3-6 and the normalised aggregate consumption is presented in figure 3-7 - the predicted residuals when regressing consumption against household covariates and district fixed effects are collapsed by mean and survey years for both control and treatment groups. Similar to the income variation, the consumtion variation in the figure 3-5 and 3-6 justify our empirical model (III, IV, V) that account for household and district heterogeneity to isolate the treatment effect. The figure 3-7 clearly depicts the parallel consumption trends before the 2004 tsunami, and the steeper increase in consumption observed for the treated (impacted) districts. The non-normalized results, further differentiated by the extent of damage (high, medium and low) in each district, are presented in a figure included in the appendix figure 3-5. In this case, we observe that the impact (the deviation from parallel trend), is possibly highest for the low-and middle-damage districts. We explore this distinction further in the next section.

We estimated the same specification, as column III, with district-time-specific fixed effects, in order to estimate the ATE for households in each district separately. We plot the district level results in figure 3- 8 (full regression results in the appendix table 3-14). We find more variation in consumption dynamics across the districts, but for 6 out of the 7 affected districts, we find the same V-shaped dynamics that we observed for income as well. And in all of these 6 cases, the largest gains in consumption are in 2012, even for districts that were experiencing, comparatively, consumption losses in 2009 (Gampha and Kalutara).

\footnotetext{
25 The consumption measure excludes expenditure on durable assets such as housing, land and other non-household durable goods such as machinery etc. The housing variable includes only rents (imputed rent for owner-occupied housing), fuel, light, and water.
} 
The household surveys include details questions about expenditure patterns, so we are able to identify the ATE for each component of expenditure (Table 3-5). Because the districts have significant district specific time trends similarly for household income (appendix 3-12), model IV including district specific linear time trend is used to distinguish the impact on the components of consumption. When distinguishing between food and non-food expenditures, we find that food consumption has actually increased in the affected districts as a consequence of the tsunami, while non-food consumption has increased only later in the post-disaster period (in 2012). When we examine non-food consumption (Table 3-6) we find, overall, increases in only some of its sub-components. We also observe very small, but statistically significant increases in expenditure on education and health (with the same V shaped pattern across the three surveys) with the largest identified increase in housing. These results, however, are not statistically promising. It is this increase in food consumption that accounts for the overall increase in consumption identified in table 3-4 and, figure3- 7 and 3-8. Especially notable is the straight successive increase of food consumption during post disaster period and decrease in non-food consumption observed in 2009 (column I Table 3-5), after the inflow of external assistance has ebbed five years after the tsunami and the economy faced the intensification of the civil conflict.

\subsection{Robustness Analyses}

One possibility is that our results are determined by outliers - i.e., households with very large incomes and expenditures. To examine this possibility, we estimated a log-normal variant of the model by log-transforming the dependent variables. The kernel density plot of residuals overlaid with normal density plot show slightly skewed error distribution. The inter-quartile range test shows the presence of 3-4\% outliers in the non-log model. Results available in the online appendix also show that the log-normal model rectifies this issues; the plot and estimation results are available in the online appendix (Table 3-4 and figure 3-8, 3-9). ${ }^{26}$ In table 3-7, columns I and II present the estimation of the determinants

\footnotetext{
${ }^{26}$ Log transformations create other issues. Income data has considerable zero and negative observations and log transformation drops those observations (column I of table 3-7). Another model is estimated using log-modulus
} 
of log income using model 2 (without and with null observations, respectively), while column III estimates the determinants of log consumption/expenditure. In columns IV and VI we estimate the previous (non-log) model but remove outlier observations. Results appear insensitive to these changes. In particular we observe the same statistically significant increases, the same $\mathrm{V}$ shaped recovery, and a similarly much larger increase in income relative to consumption (with the ATE for income larger by a factor of 3-5). A similar observation is revealed in column V and VII that provide the income and consumption respectively incorporating the district linear time trend (model 3) in the model.

In table 3-8 and 3-9, we further investigate the robustness of our results by distinguishing between the intensity of the tsunami damage in different districts and between the two richest affected regions (including the capital, Colombo), and the other, poorer, affected regions. Table 3-8 uses dummy treatment measure; we use five treatment indicators to identify treatment intensity across districts and use all five indicators to identify high and low intensity districts. In column I we include the whole sample, while in column II we exclude these two richest regions. The exclusion of the two richest districts reduces the size of the positive identified ATE by more than 50\% (compare columns I and II). This difference is most likely associated with the increased access to post-tsunami assistance for the two richest (and urban) regions that were now excluded. It is easy to observe that a similar estimation for the two richest districts, in column V, indeed supports this contention as the ATE is about 50\% higher than for the entire affected sample. The identified ATE is 3-4 times as large for the richest as for the poorest affected regions.

We associated these differences, and in general the positive ATE we identified, with the post disaster aid that flowed into the country, rather than with the tsunami damage itself.

\footnotetext{
transformation (John and Draper, 1980) to preserve the sign and zero observations (column II of table 3-6). The log transformation changes the distribution of the dependent variable. Extreme values are obviously possible in our data since we use time series data within a 15 years' time gap. This is evident in the scatter plots of log and non-log income and consumption in online appendix. The log-normal distributions suggest that the presence of outliers may bias some of our results. We therefore re-examined the validity of our results by excluding outliers $(0.5 \%$ of observations from both sides of the distribution of the LHS variables).
} 
This argument is supported by our findings in columns III and IV, in table 3-8, where we differentiate between high damage intensity and low damage intensity districts. The ATE we estimate is about 2-3 times higher for the low intensity districts, suggesting that the destruction itself was not 'creatively destructive' in and of itself, but rather that it was the interaction with post-disaster aid inflows that improved recovery and economic outcomes in the affected districts. ${ }^{27}$

In columns I - V of table 3-9, we repeat the same estimations as in columns I - V in table 3-8, but instead of estimating a diff-in-diff model relying on binary estimation of treatment, we proxy for the intensity of treatment by constructing an intensity variable that measures the share of the population in the district residing in the affected DS regions (the administrative unit below district for which we have affected population data $)^{28}$. In these estimates, we observe exactly the same pattern as we observed in columns I - V in table 3-8, with the increase in income most pronounced in the two richer districts, and in the low damage intensity ones. It is worth noting that the explanatory power of the 'damage intensity' model in table 3-9 is not very different from the diff-indiff model in columns I - V of table 3-8. However, the model parameters for low intensive damage treatment group (in both Table 3-8 and 3-9) are not statistically significant considering wild bootstrap standard errors.

Table 3-10 and 3-11 repeats the same distinctions, as in table 3-8 and 3-9, for consumption expenditure. Here, however, the results provide some additional insights rather than just confirming previous findings. In particular, we find that the ATE results for 2009 appear to be statistically unobservable (the null hypothesis of ATE=0 cannot be

\footnotetext{
27 Given the limits of our empirical approach, and especially the availability of relevant data, we are unable to precisely identify the mechanisms that led to these dynamics. For example, it might be that more benefits accrued to the wealthier districts as some of the skilled labor employed in all the other affected districts during the reconstruction came from these places, or that the quality of infrastructure in the wealthier districts enabled these to better capture the advantages of the recovery funding.

28 The interpretation of coefficients in the model is limited, nevertheless, we define treatment variation across treatment districts instead of dummy treatment variable using population exposure as a proportion of total population in each treatment district.
} 
rejected at all), while the 2012 results of increased consumption is completely driven by the increase in consumption observed in the richer and low-damage-intensity districts.

In tables 2-6 we found that the tsunami and the ensuing inflow of assistance significantly increased household income, but that consumption gains were much more limited. What explains this lack of 'pass-through' from income to consumption is not immediately obvious. Some expenditure and income components are missing in our data - most relevant seem investment in property and durable assets. Due to inconsistent survey questions across surveys, all income and expenditure components are not available in our complete time series dataset. Therefore, the average household consumption is approximately Rs. 3000 higher than the average household income reported in our summary statistics (Table 3-1). In order to provide more information on the 'missing income,' we exclude the year 2002 survey (the survey wave with most missing components) and repeated the analysis while including ad-hoc income. These regressions are available from the authors, but they clearly, and similarly, show a positive impact on income and consumption. Again, we observe income increases to be substantially larger than the identified consumption increases.

In addition, we estimated the diff-in-diff model with "affected households and predisaster 2002-year interaction variable" as a type of placebo test (appendix table 3-20). By 'pretending' that the tsunami occurred before 2002, we verify that the income and consumption of treatment and control group were not significantly different before the disaster event. We find (results available upon request) non-significant ATE for both outcome variables (income and consumption). The treatment and control groups are not different in their income and consumption before the tsunami; providing additional evidence to support the validity of our results. Further, to verify whether our identification assumption is valid, we estimated the same model (including the districtspecific linear trend) using a different control group that includes only the districts that show a distinct parallel trend in the pre- treatment period. We observe statistically significant positive impact for both income and consumption with a similar pattern to that we previously observed in the full sample (see the appendix table 3-21). 
The effect we find could also be biased if the tsunami led affected households to migrate, thus changing the sample dramatically between the pre- and post-tsunami survey waves. Large scale migration, whether it was or was not triggered by the tsunami, would bias our estimation results as the before- and after-treatment populations would be different. However, during the reconstruction process, land was allocated to affected households nearby to their pre-event location, and therefore the tsunami-induced migration of directly affected households was minimised. However, in migrations to affected districts is also possible due to economic incentives -as a result of post disaster reconstruction or the growth trends associated with affected districts (include richer districts in the country). In order to verify this claim, we examined the net migration of affected districts between 1982 and 2012 (Appendix figure 3-15). The statistics are indicative of outmigration from affected Matara, Galle, and Hambantota districts into tsunami affected Colombo, Gampaha, Kaluthara and Puttlam districts; nonetheless, the direct evidence of this is not available, these migrations were most likely motivated by increasing income in the affected urban districts. If this pattern of in migration is tsunami associated, such effect is already included in our estimates. Upward bias in our estimates is possible due to immigration from control districts that is unrelated to tsunami; for verifications, such data are not available.

\subsection{Conclusion}

Few research projects attempted to identify and quantify the long-term impact of a catastrophic disaster on household wellbeing. Most research attention is usually directed to an event in its immediate aftermath, and interest eventually wanes. From a macroeconomic perspective, the majority of the evidence points to very little aggregate effects at the national level in the long term but more substantial adverse local long-term effects. Yet, little is really known about the impacts at the micro/household level in the longer term. Here, we estimated the effect of the Indian Ocean tsunami in Sri Lanka on household income and consumption eight years after the event, using a difference-indifference method. 
A strong association between area-wide tsunami disaster shock and increases in household income and consumption in the long-term emerged from our empirical investigation. Deviating from the common observation in the literature on short-term impacts, these results are suggestive of an optimistic potential for long-lasting positive consequences. More importantly, the recovery we observe gives a record of the disaster effect on directly affected households, spillovers to unaffected neighboring households and captures ex-post reactions to the disaster.

However, we are sceptical of a causal interpretation of the evidence we presented as our analysis is incomplete and our data are insufficient to give a precise and comprehensive account. Productivity effects associate with build-back-better reconstruction is one possible causal explanation for the superior recovery we observe, but a fully effective productivity effect depends on specific productivity enhancements resulting from improved regulatory practices.

We note that Sri Lanka received a very large amount of external transfers post-tsunami, much larger than is typical for disaster events (Becerra et al., 2014 and 2015). The increases in consumption and income we identified, can be associated not with 'creative destruction', but purely due to the infusion of atypically massive amounts of external resources for rebuilding. Only an accounting for the amount of assistance received, per district, could possibly start to allow us to differentiate between these two hypotheses. Regrettably, such accounting is impossible due to the lack of data about the disbursed aid. At the time of the catastrophe, Sri Lanka was on a growth path from contraction in 2002; post disaster reconstruction possibly had acted as a stimuli. The better recovery we observed for households in richer districts is plausibly due to direct reconstruction aid flows into richer districts or indirect reconstruction spill overs from highly affected districts depending.

Our findings suggest a more nuanced picture with respect to household consumption impacts. Concurrently with the increases in income, we observe an increase of food consumption expenditure and only find a marginal increase in non-food consumption. The increase in food consumption, however, is much smaller than the increase in income. 
As household expenditures on durable assets (land, housing) are not available in all survey waves, we are unable to evaluate the translation of household income to such assets, probably to rebuild the destroyed ones. 


\section{Table 3-1 Summary statistics}

\begin{tabular}{|c|c|c|c|c|}
\hline Variable & Mean & Std. Dev. & Min & Max \\
\hline Gender (Household head; male=1) & .79 & & 0 & 1 \\
\hline Age (Household head) & 51 & 14.04 & 10 & 99 \\
\hline Education(Yrs.) (HH head) & 7 & 2.94 & 0 & 18 \\
\hline Ethnic group - Sinhalese & .85 & & 0 & 1 \\
\hline Ethnic group - Tamil & .14 & & 0 & 1 \\
\hline Religion - Buddhist & .79 & & 0 & 1 \\
\hline Religion - Hindu & .07 & & 0 & 1 \\
\hline Religion - Muslim & .06 & & 0 & 1 \\
\hline Religion - Catholic & .07 & . & 0 & 1 \\
\hline Married (Household head) & .80 & & 0 & 1 \\
\hline Wid./Divorced (HH head) & .18 & & 0 & 1 \\
\hline Not married (HH head) & .02 & & 0 & 1 \\
\hline Household size & 4 & 1.88 & 1 & 20 \\
\hline House ownership & .79 & & 0 & 1 \\
\hline Total cultivated land (Perch) & 102 & 759 & 0 & 128003 \\
\hline $\mathrm{HH}$ in rural sector & .81 & & 0 & 1 \\
\hline HH in urban sector & .13 & & 0 & 1 \\
\hline $\mathrm{HH}$ in estate sector & .05 & & 0 & 1 \\
\hline HH head employed & .57 & & 0 & 1 \\
\hline HH head unemployed & .03 & & 0 & 1 \\
\hline HH head employed in non-paid occupation & .34 & & 0 & 1 \\
\hline HH receiving transfer payments & .28 & & 0 & 1 \\
\hline HH receiving pension or disability payments & .10 & & 0 & 1 \\
\hline HH receiving local remittances & .07 & & 0 & 1 \\
\hline $\mathrm{HH}$ receiving foreign remittances & .07 & & 0 & 1 \\
\hline Transfer payments (Rs.) & 142 & 377 & 0 & 30000 \\
\hline Pension and disability payments (Rs.) & 959 & 4418 & 0 & 156000 \\
\hline Local remittance (Rs.) & 4439 & 33520 & 0 & 2400000 \\
\hline Foreign Remittance-(Rs.) & 7790 & 52799 & 0 & 2050000 \\
\hline HH after Tsunami & .64 & & 0 & 1 \\
\hline HH affected by Tsunami & .51 & & 0 & 1 \\
\hline Affected HH observed after Tsunami & .33 & & 0 & 1 \\
\hline Income (Rs./month) & 8536.23 & 12497 & -3595 & 98732 \\
\hline Consumption (Rs./month) & 11692.86 & 10584 & 297 & 87436 \\
\hline
\end{tabular}

There are 84393 observations. 
Table 3-2 Impact of tsunami on household income

\begin{tabular}{|c|c|c|c|c|c|}
\hline $\begin{array}{l}\text { Independent } \\
\text { Variables }\end{array}$ & $\begin{array}{c}\text { (i) } \\
\text { District } \\
\text { Clustered } \\
\text { Robust SE }\end{array}$ & $\begin{array}{c}\text { (ii) } \\
\text { District } \\
\text { Clustered } \\
\text { Robust SE }\end{array}$ & $\begin{array}{c}\text { (iii) } \\
\text { District } \\
\text { Clustered } \\
\text { Robust SE }\end{array}$ & $\begin{array}{c}\text { (iv) } \\
\text { District } \\
\text { Clustered } \\
\text { Robust SE }\end{array}$ & $\begin{array}{c}\text { (v) } \\
\text { District } \\
\text { Clustered } \\
\text { Robust SE }\end{array}$ \\
\hline Treatment*2006 & $\begin{array}{c}6854 \\
(2479)^{* * *}\end{array}$ & $\begin{array}{c}11107 \\
(3791)^{* * *}\end{array}$ & $\begin{array}{c}7048 \\
(2428)^{* * *}\end{array}$ & $\begin{array}{c}7022 \\
(2898)^{* * *}\end{array}$ & $\begin{array}{c}7015 \\
(3487)^{* *}\end{array}$ \\
\hline $\begin{array}{l}\text { Wildbootsrap CI } \\
\text { P value }\end{array}$ & $\begin{array}{c}{[-139,12259]} \\
(0.05)\end{array}$ & $\begin{array}{c}{[702,19242]} \\
(0.04)\end{array}$ & $\begin{array}{c}{[595.9,12538]} \\
(0.03)\end{array}$ & $\begin{array}{c}{[472.3,14006]} \\
(0.03)\end{array}$ & $\begin{array}{c}{[205.9,16476]} \\
(0.04)\end{array}$ \\
\hline Treatment*2009 & $\begin{array}{c}5044 \\
(1918)^{* * *}\end{array}$ & $\begin{array}{c}10543 \\
(2907)^{* * *}\end{array}$ & $\begin{array}{c}5870 \\
(1681)^{* * *}\end{array}$ & $\begin{array}{c}5787 \\
(2474)^{* * *}\end{array}$ & $\begin{array}{c}5773 \\
(4086)\end{array}$ \\
\hline $\begin{array}{l}\text { Wildbootsrap CI } \\
\text { P value }\end{array}$ & $\begin{array}{c}{[-3890,8953]} \\
(0.07)\end{array}$ & $\begin{array}{c}{[2310,16994]} \\
(0.01)\end{array}$ & $\begin{array}{c}{[1406,9328]} \\
(0.01)\end{array}$ & $\begin{array}{c}{[1044,12278]} \\
(0.01)\end{array}$ & $\begin{array}{c}{[-2074,17457]} \\
(0.26)\end{array}$ \\
\hline Treatment*2012 & $\begin{array}{c}16008 \\
(3735)^{* * *}\end{array}$ & $\begin{array}{c}19259 \\
(5064)^{* * *}\end{array}$ & $\begin{array}{c}15142 \\
(3992)^{* * *}\end{array}$ & $\begin{array}{c}15066 \\
(4802)^{* * *}\end{array}$ & $\begin{array}{c}15040 \\
(7262)^{* *}\end{array}$ \\
\hline $\begin{array}{l}\text { Wildbootsrap CI } \\
\text { P value }\end{array}$ & $\begin{array}{c}{[5064,24096]} \\
(0.00)\end{array}$ & $\begin{array}{c}{[5121,30362]} \\
(0.01)\end{array}$ & $\begin{array}{c}{[4433,23878]} \\
(0.01)\end{array}$ & $\begin{array}{c}{[4192,27610]} \\
(0.003)\end{array}$ & $\begin{array}{c}{[1170,36267]} \\
(0.02)\end{array}$ \\
\hline Treatment group & $\begin{array}{c}4400 \\
(1503)^{* * *}\end{array}$ & & & & \\
\hline Post tsunami & $\begin{array}{c}533 \\
(1270) \\
\end{array}$ & & & & \\
\hline Year fixed effect & No & Yes & Yes & Yes & Yes \\
\hline Household covariates & No & Yes & Yes & Yes & Yes \\
\hline District fixed effects & No & No & Yes & Yes & Yes \\
\hline District time trend & No & No & No & linear & quadratic \\
\hline constant & $\begin{array}{c}3453 \\
(920)^{* * *}\end{array}$ & $\begin{array}{c}5111 \\
(1392)^{* * *}\end{array}$ & $\begin{array}{c}-600 \\
(1050)\end{array}$ & $\begin{array}{c}1497 \\
(568)^{* * *}\end{array}$ & $\begin{array}{c}693 \\
(570) \\
\end{array}$ \\
\hline $\mathbf{F}$ & 3376 & 898.47 & & & \\
\hline R-squared & 0.29 & 0.29 & 0.49 & 0.52 & 0.52 \\
\hline
\end{tabular}

Notes: Robust standard errors in the bracket. ${ }^{* * *},{ }^{* *},{ }^{*}$, stand for significance at $1 \%, 5 \%$ and $10 \%$ respectively. The square bracket and the brackets in the row below are the wildbootsrap 95\% confidence interval and the p values respectively for the null imposed on treatment effect. There are 84393 observations. Household covariates include sex, age, years of education, ethnicity of the household head, and household size. The household (the outcome variable) include paid, agricultural and non-agricultural income, remittances, transfers, dividends, property rents and cash receipts and exclude loans, sale of assets, withdrawal of savings, insurance compensation and other adhoc gains (see appendix 1). Results in the model V remains the same by incorporating coastal and non-coastal region specific linear time trends in the model. 
Table 3-3 Impact of tsunami on household income by source of income

\begin{tabular}{|c|c|c|c|c|c|c|c|}
\hline Income sources & Paid income & $\begin{array}{l}\text { Agricultural } \\
\text { Income }\end{array}$ & Non-agricultural Income & Remittance & Transfers & Dividends & Rents and other income \\
\hline \multicolumn{8}{|c|}{ Independent Variables } \\
\hline Treatment*2006 & $\begin{array}{c}994 \\
(1282)\end{array}$ & $\begin{array}{l}-1030 \\
(574) *\end{array}$ & $\begin{array}{c}6934 \\
(2777)^{* * *}\end{array}$ & $\begin{array}{c}42 \\
(133)\end{array}$ & $\begin{array}{c}144 \\
(110)\end{array}$ & $\begin{array}{l}-18 \\
(26)\end{array}$ & $\begin{array}{l}-155 \\
(243)\end{array}$ \\
\hline $\begin{array}{l}\text { Wildbootsrap CI } \\
\text { P value }\end{array}$ & $\begin{array}{c}{[-1907,4222]} \\
(0.58)\end{array}$ & $\begin{array}{c}{[-2775,25.91]} \\
(0.06)\end{array}$ & {$[-858.9,13714](0.09)$} & {$[-297.9,304.9](0.78)$} & $\begin{array}{c}{[-91.69,480.9]} \\
(0.23)\end{array}$ & {$[-73.37,43.87](0.56)$} & $\begin{array}{c}{[-686.9,568.4]} \\
(0.56)\end{array}$ \\
\hline Treatment*2009 & $\begin{array}{c}172 \\
(1214)\end{array}$ & $\begin{array}{c}-1456 \\
(657)^{* *}\end{array}$ & $\begin{array}{c}7242 \\
(2917)^{* * *}\end{array}$ & $\begin{array}{c}59 \\
(126)\end{array}$ & $\begin{array}{c}23 \\
(197)\end{array}$ & $\begin{array}{c}-9 \\
(33)\end{array}$ & $\begin{array}{c}-44 \\
(355)\end{array}$ \\
\hline $\begin{array}{l}\text { Wildbootsrap CI } \\
\text { P value }\end{array}$ & $\begin{array}{c}{[-3075,2689]} \\
(0.91)\end{array}$ & $\begin{array}{c}{[-3054,-38.82]} \\
(0.04)\end{array}$ & $\begin{array}{c}{[-250.8,13954]} \\
(0.05)\end{array}$ & {$[-245.2,310.4](0.65)$} & {$[-408.5,572.3](0.92)$} & {$[-76.75,78.4](0.81)$} & {$[-870.3,925.8](0.90)$} \\
\hline Treatment $* 2012$ & $\begin{array}{c}4243 \\
(2181)^{* *}\end{array}$ & $\begin{array}{l}-1544 \\
(660)^{* *}\end{array}$ & $\begin{array}{c}10675 \\
(4024)^{* *}\end{array}$ & $\begin{array}{c}839 \\
(256)^{* * *}\end{array}$ & $\begin{array}{c}789 \\
(205)^{* * *}\end{array}$ & $\begin{array}{c}67 \\
(43)\end{array}$ & $\begin{array}{l}-179 \\
(360)\end{array}$ \\
\hline $\begin{array}{l}\text { Wildbootsrap CI } \\
\text { P value }\end{array}$ & $\begin{array}{c}{[-702,9151]} \\
(0.10)\end{array}$ & $\begin{array}{c}{[-3006,-114.4]} \\
(0.03)\end{array}$ & $\begin{array}{c}{[-237.8,20447]} \\
(0.05)\end{array}$ & $\begin{array}{c}{[317.6,1402]} \\
(0.004)\end{array}$ & {$[371,1383](0.002)$} & {$[-23.08,168.2](0.14)$} & $\begin{array}{c}{[-932.5,826.1]} \\
(0.67)\end{array}$ \\
\hline Constant & $\begin{array}{l}1122 \\
(880)\end{array}$ & $\begin{array}{c}-43 \\
(203)\end{array}$ & $\begin{array}{c}1205 \\
(567)^{* *}\end{array}$ & $\begin{array}{c}-286 \\
(116)^{* * *}\end{array}$ & $\begin{array}{c}-272 \\
(154)^{*}\end{array}$ & $\begin{array}{l}-23 \\
(20)\end{array}$ & $\begin{array}{c}-69 \\
(129) \\
\end{array}$ \\
\hline R-squared & 0.35 & 0.15 & 0.24 & 0.06 & 0.08 & 0.01 & 0.03 \\
\hline
\end{tabular}

Notes: District clustered robust standard errors in bracket. ${ }^{* *},{ }^{* *}, *$, stand for significance at $1 \%, 5 \%$ and $10 \%$ respectively. The square bracket and the brackets in the row below are the wild-bootstrap 95\% confidence interval and the p values respectively for the null imposed on treatment effect. There are 84393 observations. Model estimations controlled for household covariates i.e. sex, age, years of education, ethnicity of household head, and household size and, the district fixed effects and district linear time trend. 
Table 3-4 Impact of tsunami on household consumption

\begin{tabular}{|c|c|c|c|c|c|}
\hline $\begin{array}{l}\text { Independent } \\
\text { variables }\end{array}$ & $\begin{array}{c}\text { (i) } \\
\text { District } \\
\text { Clustered Robust } \\
\text { SE }\end{array}$ & $\begin{array}{c}\text { (ii) } \\
\text { District } \\
\text { Clustered Robust } \\
\text { SE }\end{array}$ & $\begin{array}{c}\text { (iii) } \\
\text { District } \\
\text { Clustered Robust } \\
\text { SE }\end{array}$ & $\begin{array}{c}\text { (iv) } \\
\text { District } \\
\text { Clustered Robust } \\
\text { SE }\end{array}$ & $\begin{array}{c}\text { (v) } \\
\text { District } \\
\text { Clustered Robust } \\
\text { SE }\end{array}$ \\
\hline Treatment*2006 & $\begin{array}{c}-1926 \\
(412)^{* * *}\end{array}$ & $\begin{array}{c}4044 \\
(961)^{* * *}\end{array}$ & $\begin{array}{c}1235 \\
(500)^{* * *}\end{array}$ & $\begin{array}{c}1343 \\
(735)^{*}\end{array}$ & $\begin{array}{c}1407 \\
(1054)\end{array}$ \\
\hline $\begin{array}{l}\text { Wildbootsrap CI } \\
\text { P value }\end{array}$ & $\begin{array}{c}{[-2827,-845]} \\
(0.00)\end{array}$ & $\begin{array}{c}{[1993,6431]} \\
(0.00)\end{array}$ & $\begin{array}{c}{[105,2575]} \\
0.04\end{array}$ & $\begin{array}{c}{[-291.4,3117]} \\
(0.10)\end{array}$ & $\begin{array}{c}{[-994.3,3994]} \\
(0.2)\end{array}$ \\
\hline Treatment*2009 & $\begin{array}{c}-3566 \\
(302)^{* * *}\end{array}$ & $\begin{array}{c}3161 \\
(986)^{* * *}\end{array}$ & $\begin{array}{c}214 \\
(279)\end{array}$ & $\begin{array}{c}333 \\
(500)\end{array}$ & $\begin{array}{c}533 \\
(1320)\end{array}$ \\
\hline $\begin{array}{l}\text { Wildbootsrap CI } \\
\text { P value }\end{array}$ & $\begin{array}{c}{[-4248,-2807]} \\
(0.00)\end{array}$ & $\begin{array}{c}{[378.6,5419]} \\
(0.03)\end{array}$ & $\begin{array}{c}{[-545.5,808.9]} \\
(0.04)\end{array}$ & $\begin{array}{c}{[-824.5,1501]} \\
(0.53)\end{array}$ & $\begin{array}{c}{[-2096,3694]} \\
(0.7)\end{array}$ \\
\hline Treatment*2012 & $\begin{array}{c}8295 \\
(926)^{* * *}\end{array}$ & $\begin{array}{c}5510 \\
(1645)^{* * *}\end{array}$ & $\begin{array}{c}2824 \\
(1096)^{* * *}\end{array}$ & $\begin{array}{c}2981 \\
(925)^{* * *}\end{array}$ & $\begin{array}{c}3324 \\
(1892)^{*}\end{array}$ \\
\hline $\begin{array}{l}\text { Wildbootsrap CI } \\
\text { P value }\end{array}$ & $\begin{array}{c}{[5029,10134]} \\
(0.00)\end{array}$ & $\begin{array}{c}{[717,9212]} \\
(0.03)\end{array}$ & $\begin{array}{c}{[-368.9,5003]} \\
(0.09)\end{array}$ & $\begin{array}{c}{[842.2,4996]} \\
(0.01)\end{array}$ & $\begin{array}{c}{[-841.4,7432]} \\
(0.11)\end{array}$ \\
\hline Treatment & $\begin{array}{c}3284 \\
(1025)^{* * *}\end{array}$ & & & & \\
\hline Post Tsunami & $\begin{array}{c}5586 \\
(228)^{* * *}\end{array}$ & & & & \\
\hline Year fixed effect & No & Yes & Yes & Yes & Yes \\
\hline $\begin{array}{l}\text { Household } \\
\text { covariates }\end{array}$ & No & Yes & Yes & Yes & Yes \\
\hline $\begin{array}{l}\text { District fixed } \\
\text { effects }\end{array}$ & No & No & Yes & Yes & Yes \\
\hline District time trend & No & No & No & linear & quadratic \\
\hline constant & $\begin{array}{l}11771 \\
(185)^{* * *}\end{array}$ & $\begin{array}{c}3782 \\
(1053)^{* * *}\end{array}$ & $\begin{array}{c}-342 \\
(1062)\end{array}$ & $\begin{array}{c}2062 \\
(1122)^{*}\end{array}$ & $\begin{array}{c}1890 \\
(1054)^{*}\end{array}$ \\
\hline $\mathbf{F}$ & 2899.12 & 994.58 & & & \\
\hline R-squared & 0.19 & 0.25 & 0.28 & 0.29 & 0.29 \\
\hline
\end{tabular}

Notes: Robust standard errors in the bracket. ${ }^{* * *}, * *$, , stand for significance at $1 \%, 5 \%$ and $10 \%$ respectively. There are 84393 observations. Household covariates include sex, age, years of education, ethnicity of the household head, and household size. The consumption (outcome variable of interest) is composed of food and non-food expenses and exclude the household investment on durable assets (land, houses, machinery etc.) The statistical significance and magnitude of coefficients remains the same by incorporating coastal and non-coastal region specific linear time trend in the model (iV) except the magnitude of impact in year 2002(Rs. 3068 significant at 1\%). 
Table 3-5 Impact of tsunami on household consumption by type of consumption

\begin{tabular}{lcc}
\hline $\begin{array}{l}\text { Dependent var. } \\
\text { Independent var. }\end{array}$ & $\begin{array}{c}\text { Food cons } \\
\text { i }\end{array}$ & $\begin{array}{c}\text { Non-food cons. } \\
\text { ii }\end{array}$ \\
\hline Treatment*2006 & 597 & 789 \\
& $(284)^{* *}$ & $(622)$ \\
Wildbootsrap CI & {$[-202.7,1180]$} & {$[-568,2300](0.23)$} \\
P value & $(0.10)$ & \\
\hline Treatment*2009 & 711 & -318 \\
& $(382)^{*}$ & $(375)$ \\
Wildbootsrap CI & {$[-350.1,1433](0.05)$} & {$[-1115,513.2](0.45)$} \\
P value & & \\
\hline Treatment*2012 & 1459 & 1546 \\
& $(525)^{* * *}$ & $(776)^{* * *}$ \\
Wildbootsrap CI & {$[-99.99,2468]$} & {$[-258.1,3267](0.07)$} \\
P value & $(0.05)$ & -1829 \\
\hline constant & 3771 & $(1154)$ \\
\hline R-squared & $(98)^{* * *}$ & 0.23 \\
\hline
\end{tabular}

Notes: Model V in table 4 is estimated for consumption and non-food consumption. 
Table 3-6 Impact of tsunami on household consumption by type of non-food consumption

\begin{tabular}{|c|c|c|c|c|c|c|c|c|c|}
\hline \multirow{2}{*}{$\begin{array}{l}\text { Dependent var. } \\
\text { Independent } \\
\text { var. }\end{array}$} & Housing & Clothing & Personal care & $\begin{array}{c}\text { Comm. \& } \\
\text { transp. }\end{array}$ & Education & Health & $\begin{array}{l}\text { HH non- } \\
\text { durables }\end{array}$ & $\begin{array}{c}\text { Non-cons. } \\
\text { Expenditure }\end{array}$ & Recreation \\
\hline & iii & iv & $\mathbf{v}$ & vi & vii & viii & ix & $\mathbf{x}$ & XI \\
\hline Treatment*2006 & $\begin{array}{c}87 \\
(173)\end{array}$ & $\begin{array}{c}112 \\
(48)^{* * *}\end{array}$ & $\begin{array}{c}7 \\
(15)\end{array}$ & $\begin{array}{c}147 \\
(94)^{* * *}\end{array}$ & $\begin{array}{c}21 \\
(23)\end{array}$ & $\begin{array}{c}45 \\
(49)\end{array}$ & $\begin{array}{c}20 \\
(16)\end{array}$ & $\begin{array}{c}339 \\
(274)\end{array}$ & $\begin{array}{c}3 \\
(32)\end{array}$ \\
\hline $\begin{array}{l}\text { WildbootsrapCI } \\
\text { P value }\end{array}$ & $\begin{array}{c}{[-262.5,589.9]} \\
(0.64)\end{array}$ & $\begin{array}{c}{[23.46,234.8]} \\
(0.001)\end{array}$ & $\begin{array}{c}{[-36.31,37.85]} \\
(0.69)\end{array}$ & $\begin{array}{c}[-91.37,360.2]] \\
(0.91)\end{array}$ & $\begin{array}{c}{[-25.76,77.04]} \\
(0.36)\end{array}$ & $\begin{array}{c}{[-80.35,151.5]} \\
(0.39)\end{array}$ & $\begin{array}{c}{[-20.66,59.22]} \\
(0.41)\end{array}$ & $\begin{array}{c}{[-216.3,1040]} \\
(0.25)\end{array}$ & $\begin{array}{c}{[-75.53,80.89]} \\
(0.94)\end{array}$ \\
\hline Treatment*2009 & $\begin{array}{c}2 \\
(118)\end{array}$ & $\begin{array}{c}64 \\
(64)\end{array}$ & $\begin{array}{c}-2 \\
(17)\end{array}$ & $\begin{array}{c}-119 \\
(50)^{* * *}\end{array}$ & $\begin{array}{c}70 \\
(19)^{* * *}\end{array}$ & $\begin{array}{c}26 \\
(31)\end{array}$ & $\begin{array}{c}8 \\
(17)\end{array}$ & $\begin{array}{c}-248 \\
(216)\end{array}$ & $\begin{array}{c}-42 \\
(43)\end{array}$ \\
\hline $\begin{array}{l}\text { Wild-bootsrap } \mathrm{CI} \\
\text { P value }\end{array}$ & $\begin{array}{c}{[-242.3,313.7]} \\
(0.98)\end{array}$ & $\begin{array}{c}{[-68.71,242.7]} \\
(0.52)\end{array}$ & $\begin{array}{c}{[-45.98,35.4]} \\
\quad(0.92)\end{array}$ & $\begin{array}{c}{[-230.5, .02126]} \\
(0.05)\end{array}$ & $\begin{array}{c}{[24.86,115.5]} \\
(0.007)\end{array}$ & $\begin{array}{c}{[-43.82,96.69]} \\
(0.46)\end{array}$ & $\begin{array}{c}{[-30.94,51.08]} \\
(0.69)\end{array}$ & $\begin{array}{c}{[-706.4,290.9]} \\
(0.30)\end{array}$ & $\begin{array}{c}{[-143.7,54.57]} \\
(0.42)\end{array}$ \\
\hline Treatment*2012 & $\begin{array}{c}653 \\
(355)\end{array}$ & $\begin{array}{c}173 \\
(112)\end{array}$ & $\begin{array}{c}45 \\
(27)^{*}\end{array}$ & $\begin{array}{c}109 \\
(201)\end{array}$ & $\begin{array}{c}197 \\
(87)^{* *}\end{array}$ & $\begin{array}{c}136 \\
(66)^{* *}\end{array}$ & $\begin{array}{c}17 \\
(25)\end{array}$ & $\begin{array}{c}216 \\
(465)\end{array}$ & $\begin{array}{c}80 \\
(40)^{* * *}\end{array}$ \\
\hline $\begin{array}{l}\text { Wildbootsrap CI } \\
\text { P value }\end{array}$ & $\begin{array}{c}{[-79.82,1553]} \\
(0.10)\end{array}$ & $\begin{array}{c}{[-58.35,469.4]} \\
(0.18)\end{array}$ & $\begin{array}{c}{[-12.08,112.3]} \\
(0.16)\end{array}$ & $\begin{array}{c}[-315.4,600.5]] \\
(0.63)\end{array}$ & $\begin{array}{c}{[12.59,412.5]} \\
(0.04)\end{array}$ & $\begin{array}{c}{[-29.77,286.5]} \\
(0.10)\end{array}$ & $\begin{array}{c}{[-40.04,85.55]} \\
(0.64)\end{array}$ & $\begin{array}{c}{[-825,1391]} \\
(0.64)\end{array}$ & $\begin{array}{c}{[-10.33,170.9]} \\
(0.08)\end{array}$ \\
\hline constant & $\begin{array}{c}-710 \\
(592) \\
\end{array}$ & $\begin{array}{c}167 \\
(44)^{* * *}\end{array}$ & $\begin{array}{c}23 \\
(21) \\
\end{array}$ & $\begin{array}{c}-662 \\
(388) \\
\end{array}$ & $\begin{array}{c}-173 \\
(72)^{* * * *}\end{array}$ & $\begin{array}{c}25 \\
(127)\end{array}$ & $\begin{array}{c}93 \\
(15)^{* * *}\end{array}$ & $\begin{array}{c}-983 \\
(211)\end{array}$ & $\begin{array}{c}47 \\
(71)\end{array}$ \\
\hline R-squared & 0.30 & 0.16 & 0.27 & 0.12 & 0.06 & 0.03 & 0.12 & 0.08 & 0.01 \\
\hline
\end{tabular}

Notes: District clustered robust standard errors in bracket. ${ }^{* *},{ }^{* *}, *$, stand for significance at $1 \%, 5 \%$ and $10 \%$ respectively. The square bracket and the brackets in the row below are the wild-bootstrap 95\% confidence interval and the p values respectively for the null imposed on treatment effect. There are 84393 observations. Model estimations controlled for household covariates i.e. sex, age, years of education, ethnicity of household head, and household size and, the district fixed effects and district linear time trend. 
Table 3-7 Impact on consumption and income using log of income and consumption (log normal)

\begin{tabular}{|c|c|c|c|c|c|c|c|}
\hline $\begin{array}{l}\text { Dependent } \\
\text { variables } \\
\text { Independent } \\
\text { variables }\end{array}$ & $\begin{array}{c}\text { Log of } \\
\text { income } \\
\text { I }\end{array}$ & $\begin{array}{c}\text { Log of } \\
\text { income } \\
\text { II }\end{array}$ & $\begin{array}{c}\text { Log of } \\
\text { Monthly } \\
\text { consumpt } \\
\text { ion } \\
\text { III }\end{array}$ & $\begin{array}{c}\text { Income } \\
\text { Removing } \\
\text { Outliers } \\
\text { IV }\end{array}$ & $\begin{array}{l}\text { Model IV with } \\
\text { District time } \\
\text { trend }\end{array}$ & $\begin{array}{c}\text { Consumptio } \\
\text { n } \\
\text { Removing } \\
\text { outliers } \\
\text { V } \\
\end{array}$ & $\begin{array}{l}\text { Model V with } \\
\text { District time } \\
\text { trend }\end{array}$ \\
\hline Treatment*2006 & $\begin{array}{l}1.32 \\
(.54)^{* *}\end{array}$ & $\begin{array}{c}3.20 \\
(1.48)^{* *}\end{array}$ & $\begin{array}{c}.02 \\
(.05)\end{array}$ & $\begin{array}{c}6936 \\
(2388)^{* *}\end{array}$ & $\begin{array}{c}6928 \\
(674)^{* * *}\end{array}$ & $\begin{array}{c}1359 \\
(474)^{* * *}\end{array}$ & $\begin{array}{c}1497 \\
(667)^{* * *}\end{array}$ \\
\hline $\begin{array}{l}\text { WildbootsrapCI } \\
\text { P value }\end{array}$ & $\begin{array}{c}{[-.18,4.7]} \\
(0.18)\end{array}$ & $\begin{array}{c}{[-.12,6.9]} \\
(0.06)\end{array}$ & $\begin{array}{c}{[-.09, .18]} \\
(0.7)\end{array}$ & $\begin{array}{c}{[452,12183]} \\
(0.03)\end{array}$ & $\begin{array}{c}{[899.6,13527]} \\
(0.02)\end{array}$ & $\begin{array}{c}{[126,2543]} \\
(0.03)\end{array}$ & $\begin{array}{c}{[54.9,3158]} \\
(0.04)\end{array}$ \\
\hline Treatment*2009 & $\begin{array}{c}2.27 \\
(.96)^{* *}\end{array}$ & $\begin{array}{l}1.23 \\
(.96)\end{array}$ & $\begin{array}{c}-.05 \\
(.02)^{* *}\end{array}$ & $\begin{array}{c}5778 \\
(1649)^{* * *}\end{array}$ & $\begin{array}{c}5708 \\
(2219)^{* * *}\end{array}$ & $\begin{array}{c}340 \\
(272)\end{array}$ & $\begin{array}{c}495 \\
(501)\end{array}$ \\
\hline $\begin{array}{l}\text { WildbootsrapCI } \\
\text { P value }\end{array}$ & $\begin{array}{c}{[-.27,5.7]} \\
(0.15)\end{array}$ & $\begin{array}{c}{[-.7,3.6]} \\
(0.32)\end{array}$ & $\begin{array}{c}{[-.1,-.001]} \\
(0.04)\end{array}$ & $\begin{array}{c}{[1387,9588]} \\
(0.01)\end{array}$ & $\begin{array}{c}{[1506,11431]} \\
(0.001)\end{array}$ & $\begin{array}{c}{[-563,776]} \\
(0.4)\end{array}$ & $\begin{array}{c}{[-644.2,1630]} \\
(0.37)\end{array}$ \\
\hline Treatment*2012 & $\begin{array}{c}2.4 \\
(.97)^{* *}\end{array}$ & $\begin{array}{l}1.45 \\
(.95)\end{array}$ & $\begin{array}{c}-.09 \\
(.04)^{* *}\end{array}$ & $\begin{array}{c}15038 \\
(3918)^{* * *}\end{array}$ & $\begin{array}{c}14968 \\
(4431)^{* * *}\end{array}$ & $\begin{array}{c}3075 \\
(1161)^{* * *}\end{array}$ & $\begin{array}{c}3280 \\
(930)^{* * *}\end{array}$ \\
\hline $\begin{array}{l}\text { WildbootsrapCI } \\
\text { P value }\end{array}$ & $\begin{array}{c}{[-.35,6.1]} \\
(0.2)\end{array}$ & $\begin{array}{c}{[-.4,3.8]} \\
(0.2)\end{array}$ & $\begin{array}{c}{[-.16, .006]} \\
(0.06) \\
\end{array}$ & $\begin{array}{c}{[4087,23850]} \\
(0.01)\end{array}$ & $\begin{array}{c}{[4892,26411]} \\
(0.001)\end{array}$ & $\begin{array}{c}{[-472,5078]} \\
(0.05)\end{array}$ & $\begin{array}{c}{[1071,5293]} \\
(0.01) \\
\end{array}$ \\
\hline Year fixed effect & Yes & Yes & Yes & Yes & Yes & Yes & Yes \\
\hline $\begin{array}{l}\text { Household } \\
\text { covariates }\end{array}$ & Yes & Yes & Yes & Yes & Yes & Yes & Yes \\
\hline $\begin{array}{l}\text { District fixed } \\
\text { effects }\end{array}$ & Yes & Yes & Yes & Yes & Yes & Yes & Yes \\
\hline $\begin{array}{l}\text { District time } \\
\text { trend }\end{array}$ & No & No & No & No & Yes & No & Yes \\
\hline Constant & $\begin{array}{c}5.68 \\
(.59)^{* * *}\end{array}$ & $\begin{array}{c}3.65 \\
(.56)^{* * *}\end{array}$ & $\begin{array}{c}7.99 \\
(.05)^{* * *}\end{array}$ & $\begin{array}{c}-660 \\
(1164)\end{array}$ & $\begin{array}{c}708 \\
(845) \\
\end{array}$ & $\begin{array}{c}2884 \\
(1032)^{* * *}\end{array}$ & $\begin{array}{c}2496 \\
(981)^{* * *}\end{array}$ \\
\hline R-squared & 0.78 & 0.74 & 0.35 & 0.53 & 0.48 & 0.31 & 0.28 \\
\hline
\end{tabular}

Notes: Column I dropped all observations for whom the dependent variable $\leq 0$ while column two includes them (by adding a small constant). District clustered robust standard errors in the bracket. ***, **, *, stand for significance at $1 \%$, $5 \%$ and $10 \%$ respectively. The square bracket and the brackets in the row below are the wildbootsrap $95 \%$ confidence interval and the $\mathrm{p}$ values respectively for the null imposed on treatment effect. There are 84393 observations. Excluding $0.5 \%$ of observations from both sides of the distribution of outcome variables in each year, estimations in column IV and V use 83171 observations. Model estimations controlled for household covariates i.e. sex, age, years of education, ethnicity of household head, and household size and, the district fixed effects and district linear time trend. 
Table 3-8 Impact on income: using dummy treatment variable considering five intensity indicators

\begin{tabular}{|c|c|c|c|c|c|}
\hline & \multicolumn{5}{|c|}{$\begin{array}{c}\text { Dummy } \\
\text { Treatment variation using all five indicators }\end{array}$} \\
\hline & $\begin{array}{l}\text { All affected } \\
\text { districts }\end{array}$ & $\begin{array}{c}\text { Exclude } \\
\text { Richest districts }\end{array}$ & High intensity & Low intensity & $\begin{array}{l}\text { Richest } \\
\text { Districts }\end{array}$ \\
\hline Treatment & 7048 & 2678 & 2626 & 6574 & 11763 \\
\hline *2006 & $(2428)^{* * *}$ & $(1568)^{*}$ & $(1280)^{* *}$ & $(3551)^{*}$ & $(1845)^{* * *}$ \\
\hline $\begin{array}{l}\text { Wildbootsrap CI } \\
\text { P value }\end{array}$ & $\begin{array}{c}{[595.9,12538]} \\
(0.03)\end{array}$ & $\begin{array}{c}{[-1737,6243]} \\
(0.18)\end{array}$ & $\begin{array}{c}{[-3131,6531]} \\
(0.14)\end{array}$ & $\begin{array}{c}{[-4125,12738]} \\
(0.54)\end{array}$ & $\begin{array}{c}{[6544,16233]} \\
(0.002)\end{array}$ \\
\hline Treatment & 5870 & 2864 & 2832 & 5572 & 9257 \\
\hline *2009 & $(1681)^{* * *}$ & $(1246)^{* *}$ & $(840)^{* * *}$ & $(2822)^{* *}$ & $(1098)^{* * *}$ \\
\hline Wildbootsrap CI & {$[1406,9328]$} & {$[-352,5590]$} & {$[-925.7,7863]$} & {$[-2709,9685]$} & {$[5773,13120]$} \\
\hline P value & $(0.01)$ & $(0.08)$ & $(0.07)$ & $(0.53)$ & $(0.001)$ \\
\hline Treatment & 15142 & 8096 & 8536 & 13406 & 22894 \\
\hline *2012 & $(3992)^{* * *}$ & $(3189)^{* * *}$ & $(1812)^{* * *}$ & $(6915)^{*}$ & $(2932))^{* * *}$ \\
\hline Wildbootsrap CI & {$[4433,23878]$} & {$[-338.3,15083]$} & {$[-1227,6838]$} & {$[-6888,22996]$} & {$[13971,30740]$} \\
\hline$P$ value & $(0.01)$ & $(0.05)$ & $(0.07)$ & $(0.50)$ & $(0.001)$ \\
\hline Constant & $\begin{array}{l}-600 \\
(1050\end{array}$ & $\begin{array}{c}3510 \\
(1212)^{* * *}\end{array}$ & $\begin{array}{c}1008 \\
(1811)\end{array}$ & $\begin{array}{c}-629 \\
(1205)\end{array}$ & $\begin{array}{c}-546 \\
(1101)\end{array}$ \\
\hline R-squared & 0.49 & 0.39 & 0.39 & 0.51 & 0.55 \\
\hline N. of obs. & 84393 & 65996 & 55974 & 52051 & 58871 \\
\hline
\end{tabular}

Notes: District clustered robust standard errors in bracket. ${ }^{* *}, * *, *$, stand for significance at $1 \%, 5 \%$ and $10 \%$ respectively. The square bracket and the brackets in the row below are the wildbootsrap 95\% confidence interval and the $\mathrm{p}$ values respectively for the null imposed on treatment effect. Model estimations controlled for household covariates i.e. sex, age, years of education, ethnicity of household head, and household size and, the district fixed effects district linear time trend. 
Table 3-9 Impact on income: using proportion of population in affected administrative districts as the treatment variable and to identify treatment intensity

\begin{tabular}{|c|c|c|c|c|c|}
\hline & \multicolumn{5}{|c|}{$\begin{array}{l}\text { Proportion of District Population in Affected Divisional secretariats } \\
\text { Treatment variation using the same measure }\end{array}$} \\
\hline & $\begin{array}{l}\text { All affected } \\
\text { districts }\end{array}$ & $\begin{array}{c}\text { Exclude } \\
\text { Richest districts }\end{array}$ & High intensity & Low intensity & Richest Districts \\
\hline $\begin{array}{l}\text { Treatment } \\
* 2006\end{array}$ & $\begin{array}{c}17287 \\
(6507)^{* * *}\end{array}$ & $\begin{array}{c}4125 \\
(1085)^{* * *}\end{array}$ & $\begin{array}{c}18258 \\
(6862)^{* * *}\end{array}$ & $\begin{array}{c}54685 \\
(16286)^{* * *}\end{array}$ & $\begin{array}{c}30833 \\
(4215)^{* * *}\end{array}$ \\
\hline $\begin{array}{l}\text { Wildbootsrap CI } \\
\text { P value }\end{array}$ & $\begin{array}{c}{[1744,30775]} \\
(0.02) \\
\end{array}$ & $\begin{array}{c}{[-683.9,16092]} \\
(0.07) \\
\end{array}$ & $\begin{array}{c}{[2016,32663]} \\
(0.01) \\
\end{array}$ & $\begin{array}{c}{[-41226,101614]} \\
(0.55) \\
\end{array}$ & $\begin{array}{c}{[18597,75386]} \\
(0.002)\end{array}$ \\
\hline $\begin{array}{l}\text { Treatment } \\
* 2009\end{array}$ & $\begin{array}{c}14165 \\
(4191)^{* * *}\end{array}$ & $\begin{array}{c}-225 \\
(977)\end{array}$ & $\begin{array}{c}14866 \\
(4226)^{* * *}\end{array}$ & $\begin{array}{c}45994 \\
(12554)^{* * *}\end{array}$ & $\begin{array}{c}23401 \\
(3474)^{* * *}\end{array}$ \\
\hline $\begin{array}{l}\text { Wildbootsrap CI } \\
\text { P value }\end{array}$ & $\begin{array}{c}{[4317,23173]} \\
(0.000)\end{array}$ & $\begin{array}{c}{[2034,15229]} \\
(0.02)\end{array}$ & $\begin{array}{c}{[3783,24019]} \\
(0.00)\end{array}$ & $\begin{array}{c}{[-26719,73302]} \\
(0.53)\end{array}$ & $\begin{array}{c}{[18028,64545]} \\
(0.001)\end{array}$ \\
\hline $\begin{array}{l}\text { Treatment } \\
*_{2012}\end{array}$ & $\begin{array}{c}37834 \\
(9834)^{* * *}\end{array}$ & $\begin{array}{c}2487 \\
(3667)\end{array}$ & $\begin{array}{c}39366 \\
(10466)^{* * *}\end{array}$ & $\begin{array}{c}110881 \\
(30475)^{* * *}\end{array}$ & $\begin{array}{c}59972 \\
(8441)^{* * *}\end{array}$ \\
\hline $\begin{array}{l}\text { Wildbootsrap CI } \\
\text { P value }\end{array}$ & $\begin{array}{c}{[14388,57459]} \\
(0.00)\end{array}$ & $\begin{array}{c}{[11120,39788]} \\
(0.02)\end{array}$ & $\begin{array}{c}{[13520,60970]} \\
(0.001)\end{array}$ & $\begin{array}{c}{[-68800,171545]} \\
(0.55)\end{array}$ & $\begin{array}{c}{[41490,158858]} \\
(0.001)\end{array}$ \\
\hline Constant & $\begin{array}{l}-1193 \\
(1127) \\
\end{array}$ & $\begin{array}{c}2620 \\
(1073) * *\end{array}$ & $\begin{array}{c}-980 \\
(1134)\end{array}$ & $\begin{array}{ll}-323 \\
(1207)\end{array}$ & $\begin{array}{l}-1308 \\
(1074)\end{array}$ \\
\hline $\begin{array}{l}\text { R-squared } \\
\text { N. of obs. }\end{array}$ & $\begin{array}{c}0.48 \\
84393\end{array}$ & $\begin{array}{c}0.25 \\
65996\end{array}$ & $\begin{array}{c}0.51 \\
67573\end{array}$ & $\begin{array}{c}0.52 \\
52051\end{array}$ & $\begin{array}{c}0.54 \\
58871\end{array}$ \\
\hline
\end{tabular}

Notes: District clustered robust standard errors in bracket. ***, **, *, stand for significance at $1 \%, 5 \%$ and $10 \%$ respectively. The square bracket and the brackets in the row below are the wildbootsrap 95\% confidence interval and the $\mathrm{p}$ values respectively for the null imposed on treatment effect. Model estimations controlled for household covariates i.e. sex, age, years of education, ethnicity of household head, and household size and, the district fixed effects district linear time trend. 
Table 3-10 Impact on consumption: using dummy treatment variable considering five intensity indicators

\begin{tabular}{lccccc}
\hline \multicolumn{5}{c}{ Treatment variation using all five indicators } \\
& \multicolumn{5}{c}{ Dummy } \\
\cline { 2 - 6 } & $\begin{array}{c}\text { All affected } \\
\text { districts }\end{array}$ & $\begin{array}{c}\text { Exclude } \\
\text { Richest districts }\end{array}$ & High intensity & Low intensity & $\begin{array}{c}\text { Richest } \\
\text { Districts }\end{array}$ \\
\hline Treatment & 1235 & 1621 & 426 & 886 \\
$* \mathbf{2 0 0 6}$ & $(500)^{* * *}$ & $(466)^{* * *}$ & $(421)^{* * *}$ & $(479)$ & $(702)$ \\
Wildbootsrap CI & {$[105,2575]$} & {$[697.2,2381]$} & {$[362.7,3481]$} & {$[-2237,2697]$} & {$[-1414,2639]$} \\
P value & 0.04 & $(0.01)$ & $(0.05)$ & $(0.40)$ & $(0.39)$ \\
\hline Treatment & 214 & -55 & -424 & 291 & 510 \\
*2009 & $(279)$ & $(331)$ & $(330)$ & $(156)^{*}$ & $(251)^{* *}$ \\
Wildbootsrap CI & {$[-545.5,808.9]$} & {$[-1065,673.2]$} & {$[-1133,525.6]$} & {$[-387.2,606.9]$} & {$[-1072,942.1]$} \\
P value & $(0.04)$ & $(0.70)$ & $(0.46)$ & $(0.34)$ & $(0.47)$ \\
\hline Treatment & 2824 & 1251 & -449 & 3335 & 4507 \\
$*$ 2012 & $(1096)^{* * *}$ & $(1281)$ & $(891)$ & $(752)^{* * *}$ & $(745)^{* * *}$ \\
Wildbootsrap CI & {$[-368.9,5003]$} & {$[-3606,3433]$} & {$[-1122,477.4]$} & {$[-282,6979]$} & {$[1943,6865]$} \\
P value & $(0.09)$ & $(0.92)$ & $(0.46)$ & $(0.06)$ & $(0.002)$ \\
\hline Constant & -342 & 3291 & 413 & 973 & 2273 \\
& $(1062)$ & $(1209) * * *$ & $(1043)$ & $(777)$ & $(1496)$ \\
\hline R-squared & 0.28 & 0.25 & 0.24 & 0.27 & 0.30 \\
N. of obs. & 84393 & 65996 & 55974 & 52051 & 58871 \\
\hline
\end{tabular}

Notes: District clustered robust standard errors in bracket. ${ }^{* *}, * *, *$, stand for significance at $1 \%, 5 \%$ and $10 \%$ respectively. The square bracket and the brackets in the row below are the wildbootsrap $95 \%$ confidence interval and the $\mathrm{p}$ values respectively for the null imposed on treatment effect. Model estimations controlled for household covariates i.e. sex, age, years of education, ethnicity of household head, and household size and, the district fixed effects and district linear time trend. 
Table 3-11 Impact on consumption: using proportion of population in affected administrative districts as the treatment variable and to identify treatment intensity

\begin{tabular}{|c|c|c|c|c|c|}
\hline & \multicolumn{5}{|c|}{$\begin{array}{l}\text { Proportion of District Population in Affected Divisional secretariats } \\
\text { Treatment variation using the same measure }\end{array}$} \\
\hline & $\begin{array}{l}\text { All affected } \\
\text { districts }\end{array}$ & $\begin{array}{c}\text { Exclude } \\
\text { Richest districts }\end{array}$ & High intensity & Low intensity & Richest Districts \\
\hline $\begin{array}{l}\text { Treatment } \\
* 2006\end{array}$ & $\begin{array}{c}3536 \\
(981)^{* * *}\end{array}$ & $\begin{array}{c}4125 \\
(1085)^{* * *}\end{array}$ & $\begin{array}{c}3340 \\
(1004)\end{array}$ & $\begin{array}{c}2387 \\
(3250)^{* * *}\end{array}$ & $\begin{array}{c}291 \\
(1302)^{* *}\end{array}$ \\
\hline $\begin{array}{l}\text { Wildbootsrap CI } \\
\text { P value }\end{array}$ & $\begin{array}{c}{[1073,6568]} \\
(0.02) \\
\end{array}$ & $\begin{array}{c}{[1634,7475]} \\
(0.02)\end{array}$ & $\begin{array}{c}{[652.3,6119]} \\
(0.04) \\
\end{array}$ & $\begin{array}{c}{[-17142,22249]} \\
(0.48) \\
\end{array}$ & $\begin{array}{c}{[-6916,11289]} \\
(0.50) \\
\end{array}$ \\
\hline $\begin{array}{l}\text { Treatment } \\
* 2009\end{array}$ & $\begin{array}{c}186 \\
(767)\end{array}$ & $\begin{array}{c}-225 \\
(977)\end{array}$ & $\begin{array}{c}281 \\
(864)\end{array}$ & $\begin{array}{c}2289 \\
(885)^{* * *}\end{array}$ & $\begin{array}{c}926 \\
(546)^{*}\end{array}$ \\
\hline $\begin{array}{l}\text { Wildbootsrap CI } \\
\text { P value }\end{array}$ & $\begin{array}{c}{[-2272,1566]} \\
(0.8)\end{array}$ & $\begin{array}{c}{[-2400,1850]} \\
(0.78)\end{array}$ & $\begin{array}{c}{[-2615,1903]} \\
(0.72)\end{array}$ & $\begin{array}{c}{[-3235,5058]} \\
(0.30)\end{array}$ & $\begin{array}{c}{[-3855,1627]} \\
(0.51)\end{array}$ \\
\hline $\begin{array}{l}\text { Treatment } \\
*_{2012}\end{array}$ & $\begin{array}{c}5887 \\
(3379)^{*}\end{array}$ & $\begin{array}{c}2487 \\
(3667)\end{array}$ & $\begin{array}{c}6779 \\
(3570)^{*}\end{array}$ & $\begin{array}{c}24877 \\
(3943)^{* * *}\end{array}$ & $\begin{array}{c}11922 \\
(1793)^{* * *}\end{array}$ \\
\hline $\begin{array}{l}\text { Wildbootsrap CI } \\
\text { P value }\end{array}$ & $\begin{array}{c}{[-4904,11836]} \\
(0.25)\end{array}$ & $\begin{array}{c}{[-5066,11664]} \\
(0.60)\end{array}$ & $\begin{array}{c}{[-5052,13355]} \\
(0.27)\end{array}$ & $\begin{array}{c}{[-4149,55700]} \\
(0.07)\end{array}$ & $\begin{array}{c}{[5776,32343]} \\
(0.003)\end{array}$ \\
\hline Constant & $\begin{array}{c}-498 \\
(1025)\end{array}$ & $\begin{array}{c}2620 \\
(1073)^{* *}\end{array}$ & $\begin{array}{l}-914 \\
(965)\end{array}$ & $\begin{array}{l}1000 \\
(779)\end{array}$ & $\begin{array}{c}2128 \\
(1481)\end{array}$ \\
\hline $\begin{array}{l}\text { R-squared } \\
\mathrm{N} \text {. of obs. }\end{array}$ & $\begin{array}{c}0.28 \\
84393\end{array}$ & $\begin{array}{c}0.25 \\
65996\end{array}$ & $\begin{array}{c}0.29 \\
67573\end{array}$ & $\begin{array}{c}0.27 \\
52051\end{array}$ & $\begin{array}{c}0.30 \\
58871\end{array}$ \\
\hline
\end{tabular}

Notes: District clustered robust standard errors in bracket. ***, **, *, stand for significance at $1 \%, 5 \%$ and $10 \%$ respectively. The square bracket and the brackets in the row below are the wildbootsrap 95\% confidence interval and the $\mathrm{p}$ values respectively for the null imposed on treatment effect. Model estimations controlled for household covariates i.e. sex, age, years of education, ethnicity of household head, and household size and, the district fixed effects and district linear time trend. 
Figure 3-1 Household income across treatment and control groups

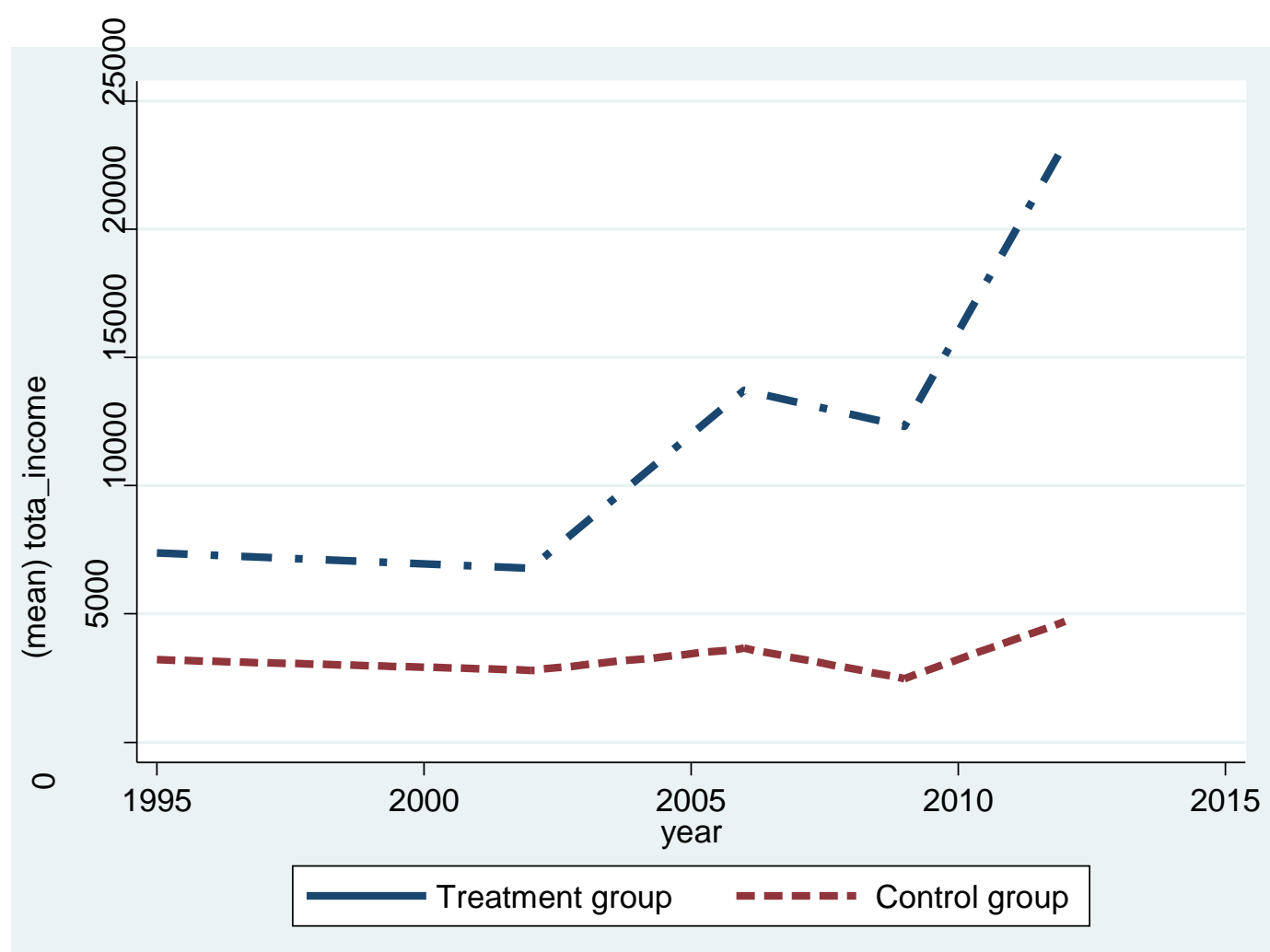

Figure 3-2 Household income across districts

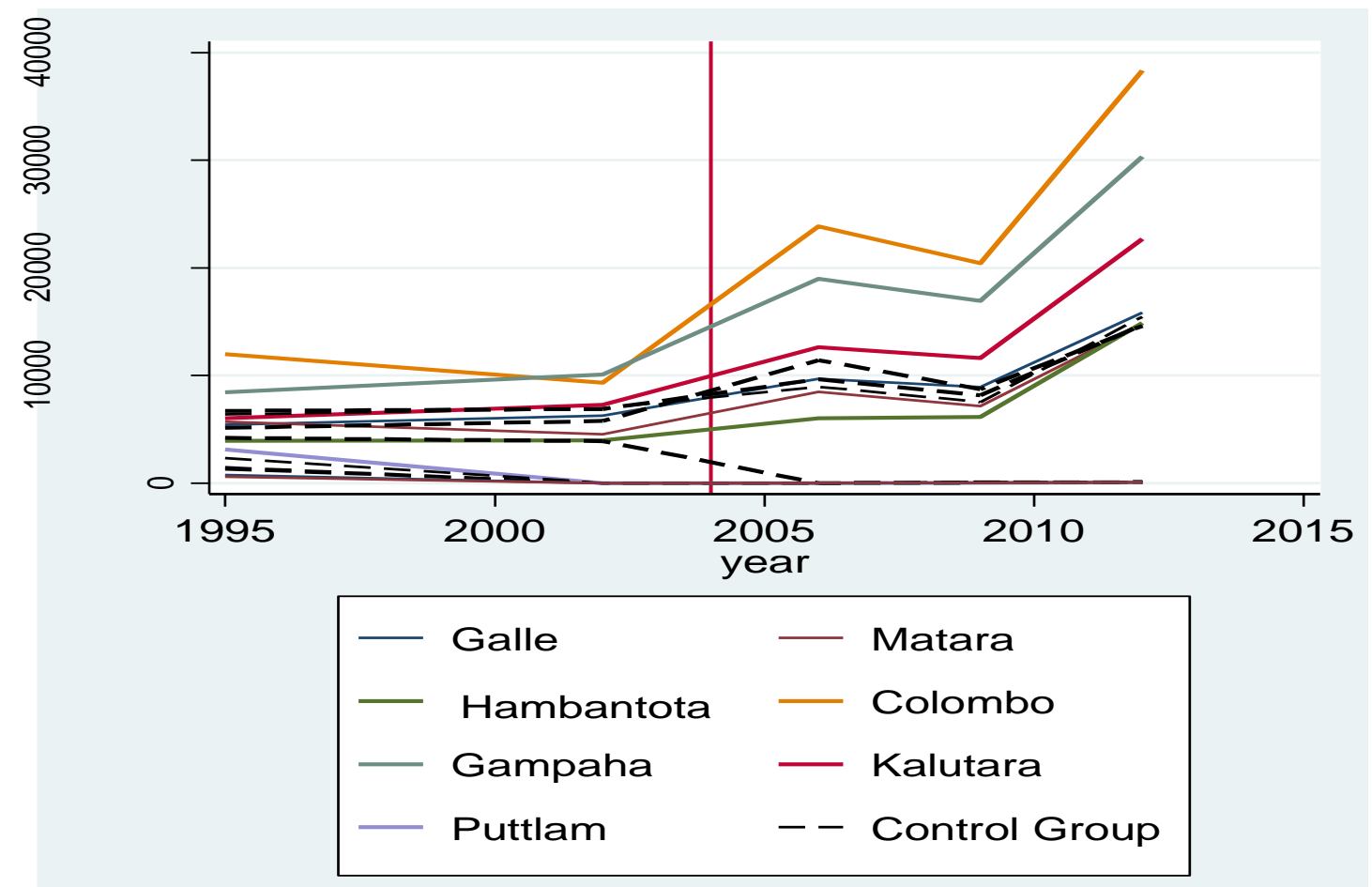


Figure 3-3 Normalized household income of treatment and control group

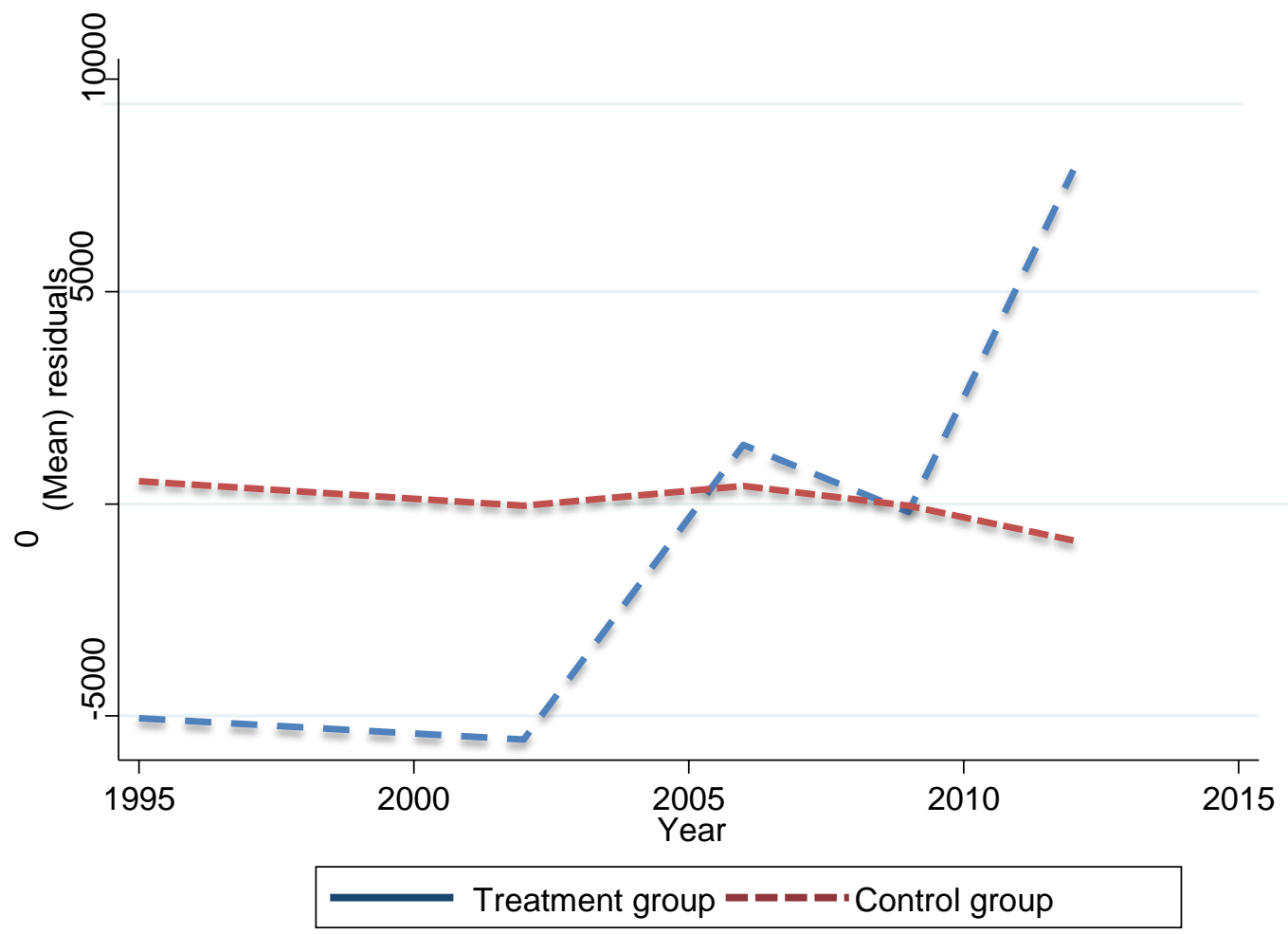

Figure 3-4 Impact on household income across affected districts in the post tsunami

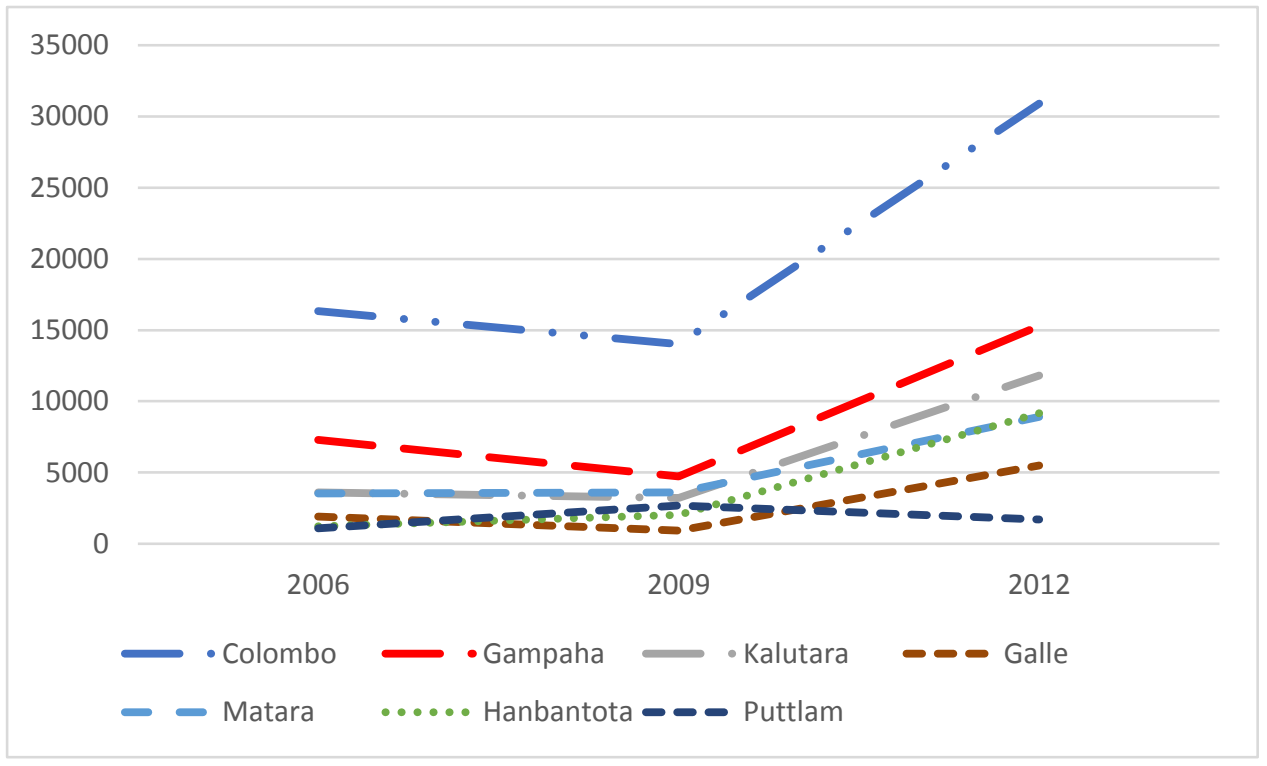

Figure 3-5 Household consumption variation across treatment and control groups 


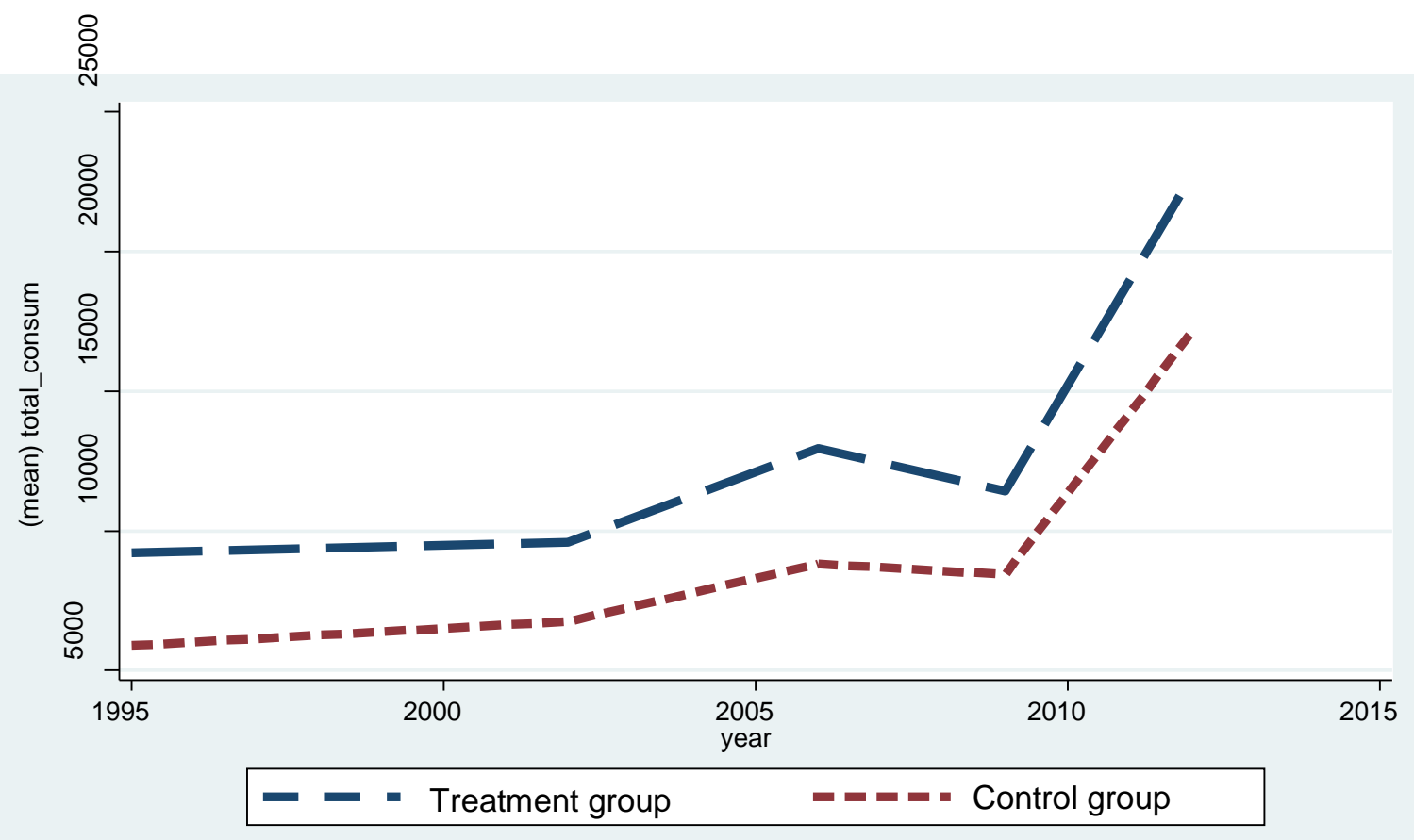

Figure 3-6 Household income consumption variation across treatment and control districts

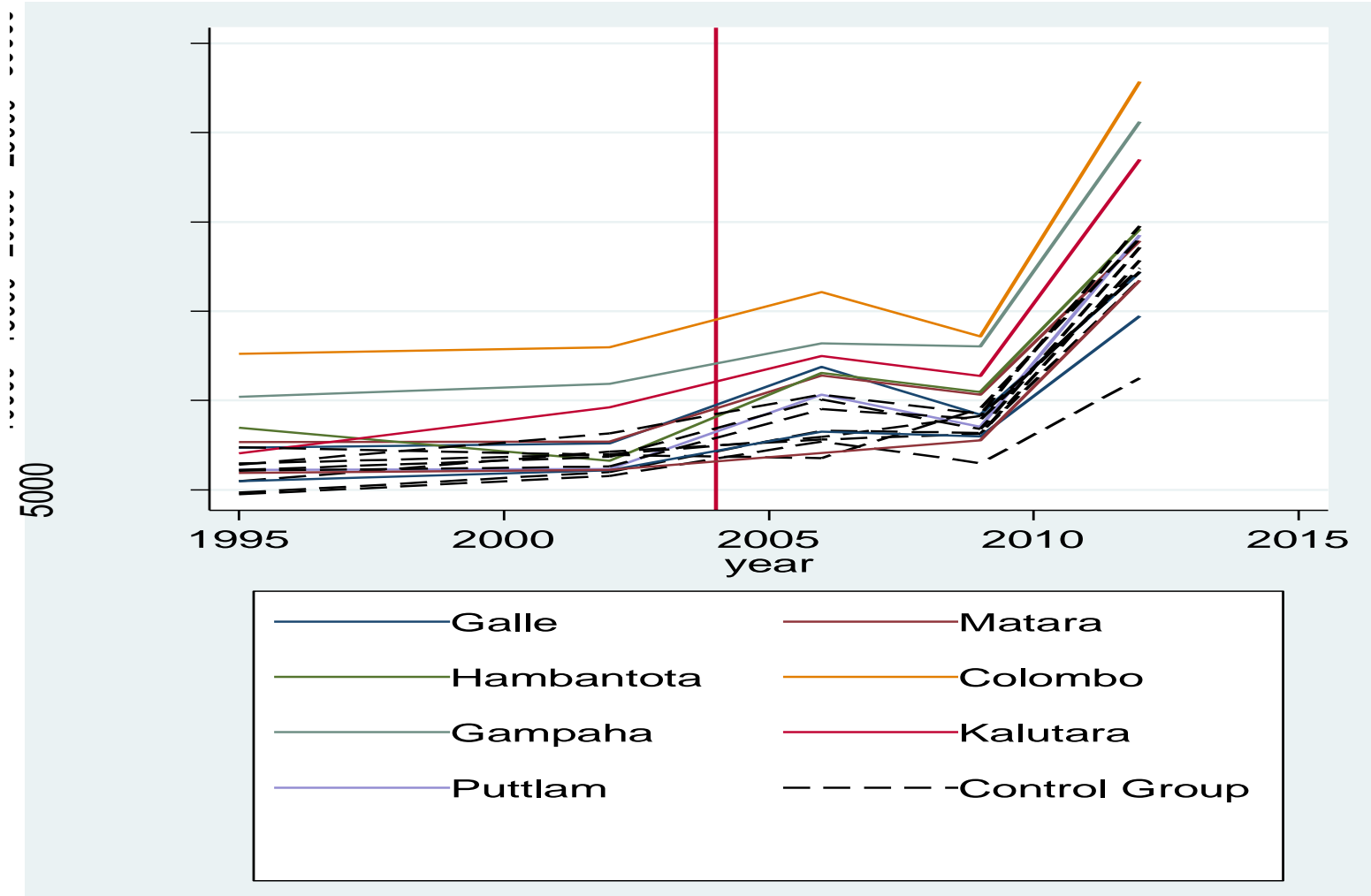

Figure 3-7 Normalized household consumption of treatment and control groups 


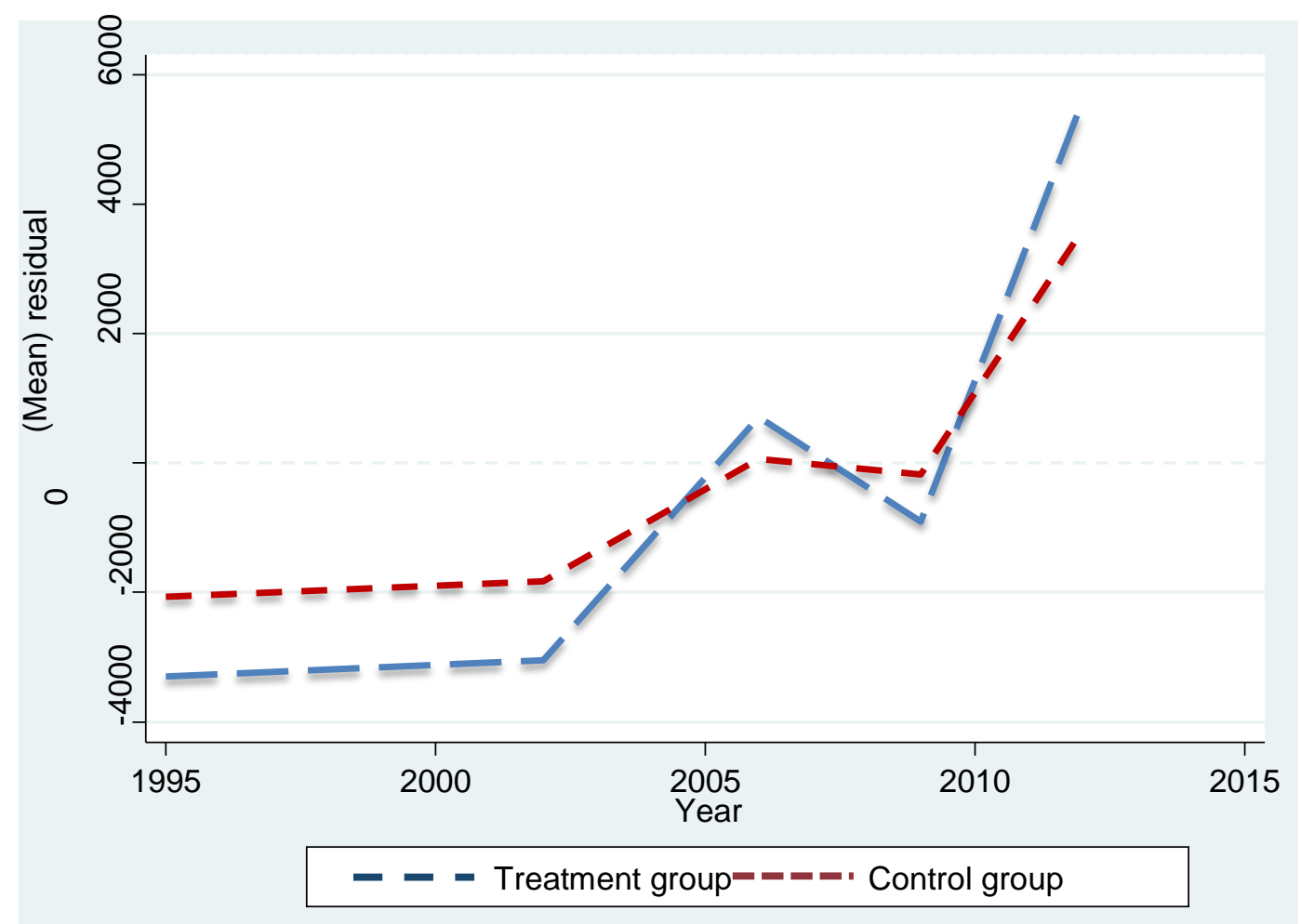

Figure 3-8 Impact on household consumption across districts in the post tsunami

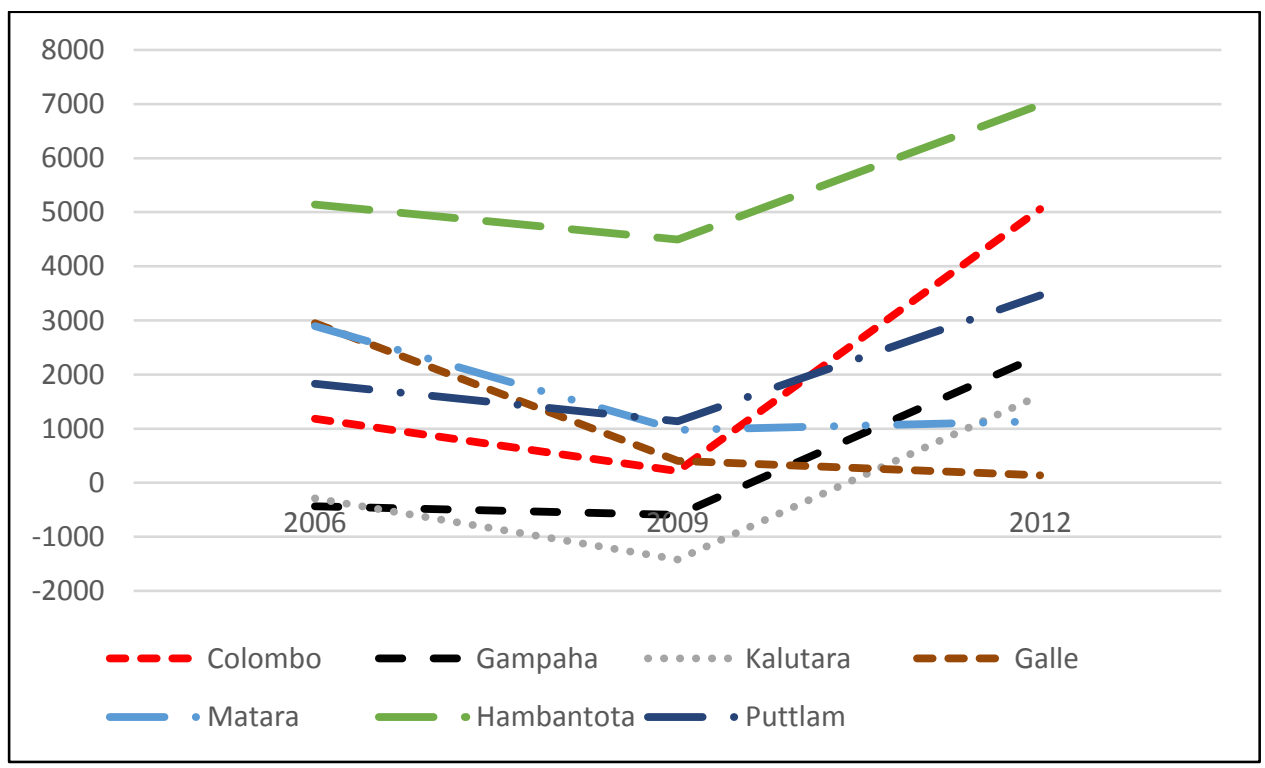




\subsection{References}

Aizenman, J., \& Noy, I. (2015). Saving and the long shadow of macroeconomic shocks. Journal of Macroeconomics, 46, 147-159.

Albala-Bertrand, J. M., (1993). Natural disaster situations and growth: A macroeconomic model for sudden disaster impacts, World Development, 21(9), 1417-1434.

Alderman, H., Hoddinott, J., \& Kinsey, B. (2006). Long term consequences of early childhood malnutrition. Oxford Economic Papers, 58, 450-474.

Aldrich, D.P. (2010), Separate and unequal: Post-tsunami aid distribution in Southern India, Social Science Quarterly, 91(5), 1369-1389.

Alesch, D.J., Arendt, L.A. \& Holly, J.N. (2009). Managing for long-term community recovery in the Aftermath of Disaster. Fairfax VA: Public Entity Risk Institute.

Athukorala, P. (2012). Indian Ocean tsunami: Disaster, generosity and recovery. Asian Economic Journal, 26(3), 211-231.

Becchetti, L. \& Castriota, S. (2011). Does microfinance work as a recovery tool after disasters? Evidence from the 2004 Tsunami. World Development 39(6), 898-912.

Becchetti, L., Castriota, S., \& Conzo, P., (2012). Calamity, aid and indirect reciprocity: the Long run impact of Tsunami on altruism. CEIS research paper series 239. 10(8).

Becerra, O., Cavallo, E., \& Noy, I. (2014). Foreign aid in the aftermath of large natural disasters. Review of Development Economics, 18(3), 445-460.

Becerra, O., Cavallo E, \& Noy, I. (2015). Where is the Money? Post-disaster foreign aid flows. Environment and Development Economics, 20(5), 561-586.

Baez, J. E. (2006). Income volatility, risk-coping behavior and consumption smoothing mechanisms in developing countries: A Survey. Desarrolloy Sociedad, 58, 37-83.

Baez, J. \& Mason, A. (2008). Dealing with climate change: Household risk management and adaptation in Latin America (background paper for the 2008 World Bank Flagship Report on Climate Change in Latin American and the Caribbean). Washington, DC: The World Bank.

Barrett, C.B., Marenya, P.P., McPeak, J., Minten, B., Murithi, F., Oluoch-Kosura, W., Place, F., Randrianarisoa, J.C., Rasambainarivo, J., \& Wangila, J. (2006). Welfare dynamics in rural Kenya and Madagascar. Journal of Development Studies, 42(2), 248-277. 
Benson, C. and Clay. E. J. (2004). Understanding the economic and financial Impacts of natural disasters (Disaster Risk Management Series No. 4). Washington DC: United States: World Bank.

Brata, A. G., Henri L. F. de Groot \& Rietveld, P. (2014). The impact of the Indian Ocean tsunami and the Nias Earthquake on the spatial distribution of Population in Northern Sumatra. Bulletin of Indonesian Economic Studies, 50(1), 101-121.

Brookshire, D. S., Chang, S. E., Cochrane, H., Olson, R. A., Rose, A., \& Steenson, J. (1997). Direct and Indirect Economic Losses from Earthquake Damage. Earthquake Spectra 13(4): 683-701.

Callen, M. (2012). Catastrophes and Time Preference: Evidence from the Indian Ocean earthquake. Working paper, ULCA.

Cassar, A., Healy, A., \& Kessler, C. (2011). Trust, risk and time preferences after natural disasters: Experimental evidence from Thailand. Working paper, university of San Francisco.

Carter M. R. \& Barrett, C. B. (2006). The economics of poverty traps and persistent Smoothing and Asset Protection. Journal of Development Studies 42(2), 178-199.

Carter, M. R., Little, P. D., Mogues, T., \& Negatu, W. (2007). Poverty traps and the longterm consequences of natural disasters in Ethiopia and Honduras. World Development, 35 (5), 835-56.

Caruso, G. \& Miller, S. (2015). Long run effects and intergenerational transmission of natural disasters: A case study on the 1970 Ancash Earthquake. Journal of development Economics, 117, 134-150.

Cavallo, E. \& Noy, I. (2011). The economics of natural disasters: A survey. International Review of Environmental and Resource Economics, 5, 63-102.

Central Bank of Sri Lanka (2015). Socio economic data. Retrieved from http://www.cbsl.gov.lk/pics_n_docs/10_pub/_docs/statistics/other/Socio_Econ_D ata_2015_e.pdf.

Chang, S.E. (2000). Disasters and transport Systems: Loss, recovery, and competition at the port of Kobe after the 1995 Earthquake. Journal of Transport Geography, 8(1), 53-65.

Chang, S.E. (2010). Urban disaster recovery: A measurement framework with application to the 1995 Kobe Earthquake. Disasters, 34(2), 303-327.

Cochrane, H.C. (2004). Indirect losses from natural disasters: Measurement and myth. In: Yasuhide Okuyama and Stephanie E. Chang (Eds.), Modelling the Spatial and Economic Effects of Disasters. New York: Springer. 
Coffman, M., \& Noy, I. (2012). Hurricane Iniki: Measuring the long-term economic impact of a Natural Disaster using synthetic control. Environment and Development Economics, 17(2), 187-205.

Cruso, G \& Miller, S. (2015). Long run effects and intergenerational transmission of natural disasters: A case study on the 1970 Ancash Earthquake. Journal of Development Economics, 117(C), 134-150

Cuaresma, J. C. (2009). Natural disasters and human capital accumulation (Policy Research Working Paper 4862). The World Bank.

Cuaresma, J.C., Hlouskova, J., \& Obersteiner, M. (2008). Natural disasters as creative destruction? Evidence from developing countries. Economic Inquiry, 46(2), 214226.

Dacy, D.C. \& Kunreuther, H. (1969). The Economics of natural disasters. New York: Free Press.

De Mel, S., McKenzie, D., \& Woodruff, C. (2011). Enterprise recovery following Natural Disasters. Economic Journal, 122, 64-91.

Dercon, S., \& Christiaensen, L. (2011). Consumption risk, technology adoption, and poverty traps: evidence from Ethiopia. Journal of Development Economics, 96(2), 159-73.

Dercon, S., Hoddinott, J. \& Woldehanna, T. (2007). Growth and poverty in rural Ethiopia. Background Paper for the Chronic Poverty Report 2008-09. Chronic poverty Research Centre.

Department of Census and Statistics. (2015). District statistical handbook. Retrieved from http://www.statistics.gov.lk/

Department of Census and Statistics. (2013). Census of Population and Housing-final report 2013._Retrieved from http://www.statistics.gov.lk/PopHouSat/CPH2011/Pages/Activities/Reports/Fin alReport/FinalReport.pdf

Department of Census and Statistics (2005). Report on impact of tsunami 2004 on Sri Lanka. Retrieved from http://www.statistics.gov.lk/tsunami/census/Summarynew.pdf

Department of Census and Statistics. Poverty indicators: Household income and expenditure survey - 2012/13. Retrieved from http://www.statistics.gov.lk/poverty/PovertyIndicators2012_13.pdf 
Deshingkar, P. \& Aheeyarse, M. M. M. (2006) Remittances in crisis remittances in Sri Lanka after the tsunami, Background paper to The Humanitarian Policy Group. UK: The Overseas Development Institute.

Fleck, R.K. \& Kilby, C. (2010). Changing aid regimes? U.S. foreign aid from the Cold War to the War on Terror. Journal of Development Economics, 91(2): 185-197.

Fleming, A. D., Chong, A. E., \& Bejarano, H. D. (2011). Natural disasters and trusting behaviour: evidence from 2010 Chilean earthquake. Annual meeting, July-24-26, 2011, Pittsburgh, Pennsylvania 104522. Agricultural and applied Economics association.

Francken, N., Bart, M., \& Swinnen, j. F. M. (2012). The political economy of relief aid allocation: Evidence from Madagascar. World Development, 40, 486-500.

Government of Sri Lanka. (2005). Post tsunami recovery and reconstruction strategy, May 2005.

Gröger, A. \& Zylberberg, Y. (2016). Internal labour migration as a shock coping strategy: Evidence from a Typhoon. American Economic Journal: Applied Economics, 8(2): 123-153.

Hallegatte, S. (2008). An Adaptive Regional InputOutput Model and Its Application to the assessment of the Economic Cost of Katrin a. Risk Analysis 28 (3):779-99.

Hallegatte, S., \& Dumas, P. (2009). Can natural disasters have positive consequences?: investigating the role of embodied technical change, Ecological economics, 68,777786.

Hallegatte, S., Bangalore, M., Bonzanigo, L., Fay, M., Narloch, U., Rozenbuerg, J., \& VogtSchilb, A, (2014). Climate change and poverty: An analytical framework. (Policy research working paper 7126). The World Bank.

Hallegatte, S. \& Przyluski, V. (2010). The economics of natural disasters: Concepts and methods. (Policy research working paper 5507). The World Bank.

Hallegatte, S. \& Vogt-Schilb, A. (2016). Are losses from natural disasters more than just asset losses? : The role of capital aggregation, sector interactions, and investment behaviors. World Bank policy research working paper no. 7885.

Halliday, T. (2012). Intra-household labour supply, migration, and subsistence constraints in a risky environment: Evidence from rural El Salvador. European Economic Review, 56(6), 1001-1019.

Hoddinott, J. (2006). Shocks and their consequences across and within households in Rural Zimbabwe. Journal of Development Studies, 42(2), 301-321. 
Hornbeck, R. \& Keniston, D. (2014). Creative destruction: Barriers to urban growth and the Great Boston fire of 1872 (Working paper 20467). National Bureau of Economic research, Cambridge.

Huang, L., Bao, W., Chen, K., \& Bi, J. (2014). The comparison analysis of Chinese public perception of earthquakes on different time scales. Nat Hazards, 73, 613-625.

Ingram, J. C., Franco, G., Rumbaitis-del Rio, C, \& Khazai, B. (2006). Post-disaster recovery dilemmas: challenges in balancing short-term and long-term needs for vulnerability reduction. Environmental Science and Policy, 9(7-8), 607-613.

Janzen, S., \& Carter, M. (2013) After the Drought: The impact of micro insurance on consumption. (NBER Working Paper No. 19702).

Jayasuriya, S., \& McCawley, P. (2010). The Asian tsunami: Aid and reconstruction after tsunami. Asian Development Bank institute, Cheltenham, UK: Edward Elgar Publishing.

John, J. A., \& Draper, N. R. (1980). An alternative family of transformations. Journal of the Royal Statistical Society, Series C (Applied Statistics), 29(2), 190-197.

Joint Report of GOSL and Development Partners (2005). Sri Lanka post tsunami reconstruction and recovery. Retrieved from http://www.preventionweb.net/files/1591_9792.pdf

Kazianga, H., \& Udry, C. (2006). Consumption smoothing? Livestock, insurance and drought in rural Burkina Faso. Journal of Development Economics, 79(2), 413-46.

Klomp, J., \& Valckx K. (2014). Natural disasters and economic growth: A meta-analysis. Global Environmental Change, 26, 183-195.

Lam, N.S.N., Pace, K. Campanella, R. LeSage, J. \& H. Arenas. (2009). Business Return in New Orleans: Decision making amid Post-Katrina uncertainty. PLoS ONE 4(8): e6765.

Lazzaroni, S. \& van- Bergeijk P. A. G. (2014). Natural disasters' impact, factors of resilience and development: A meta-analysis of the macroeconomic literature. Ecological Economics, 107, 333-346.

Le Dé, L., Gaillard, J.C., \& Friesen, W. (2015). Poverty and disaster: Do remittances reproduce vulnerability. Journal of Development Studies 51(5).

Little, P.D., Stone, M.P., Mogues, T., Castro, A.P. \& Negatu, W. (2006). 'Moving in place': Drought and poverty dynamics in South Wollo, Ethiopia. Journal of Development Studies, 42(2), 200-225.

Lynham, J., Noy, I., \& Page, J. (2017). The 1960 tsunami in Hawaii: Long-term consequences of coastal disaster. World Development, 94, 106-118. 
McCarthy, C \& Smith, S. K. (2009). Fleeing the Storm(s): An examination of evacuation behaviour during Florida's 2004 hurricane season. Demography, 46(1), 127-145.

Mechler, R., Linnerooth-Bayer, J., \& Peppiatt, D. (2006). Micro insurance for natural disasters in developing countries: Benefits, limitations and viability. ProVention Consortium, Geneva. Retrieved from:

http://www.proventionconsortium.org/themes/default/pdfs/Microinsurance_study_ july06pdf

Miles, S. B. \& Chang, S. E. (2003). Urban disaster recovery: A framework and simulation model. Technical report MCEER-03-0005.

Mogues, T. (2011). Shocks and asset dynamics in Ethiopia. Economic Development and Cultural Change, 60(1), 91-120.

Mohapatra, S., Joseph, G., \& Ratha, D. (2009). Remittances and natural disasters: Ex-Post response and contribution to Ex-Ante Preparedness. (Policy Research Working Paper 4972). Washington, DC: The World Bank.

Munasinghe, M., Munasinghe, S., Deraniyagala, Y., Perera, S., Jayasinghe, P., Sapukotana, U., \& Dharmaratna, I. (2007). Aftermath of the tsunami. Colombo, Sri Lanka: Munasinghe Institute of Development.

Noy, I \& DuPont, W. (2016). The long term consequences of natural disasters: A summary of the literature. (SEF working paper 02/2016). School of Economics and Finance, Victoria University of Wellington.

Noy, I., \& Patel, P. (2014). Floods and spillovers: Households after the 2011 great flood in Thailand (Working Paper Series No. 3609). Victoria University of Wellington, School of Economics and Finance.

Okuyama, Y. (2003). Economics of natural disasters: A Critical review. Research paper 2003-12. Regional research Institute, West Virginia University.

Okuyama, Y., Hewings, G. J.D. \& Sonis, M. (2004). Sequential interindustry model (SIM) and impact analysis: application for measuring economic impact of unscheduled events. In Okuyama ,Y. \& Chang, S. (eds), Modeling Spatial and Economic Impacts of Disasters. Berlin: Springer

Poontirakul, P., Brown, C., Seville, E., Vargo, J., \& Ilan Noy (2017). Insurance as a doubleedged sword: Quantitative evidence from the 2011 Christchurch earthquake. The Geneva papers, 42, 609-632.

Quddas, M., Goldsby, M., and Farooque,M. (2000) Trust: the social virtues and creation of prosperity. Earstrn journa,. 26(1). 
Rose, A. Z. (2009). A Framework for analyzing the total economic impacts of terrorist attacks and natural disasters (Published Articles \& Papers, Paper 78). Retrieved from http://research.create.usc.edu/published_papers/78.

Rose, A. and G. Guha (2004), Computable general equilibrium modeling of electric utility lifeline losses from earthquakes, in Y. Okuyama and S. Chang (eds), Modeling the Spatial Economic Impacts of Natural Hazards Heidelberg, 119-42.

Rose, A. \& Szelazek, T. (2011). An analysis of the business continuity industry. Los Angeles, CA: University of Southern California Centre for Risk and Economic Analysis of Terrorism Events.

Adam, R. \& Wei, D. (2013). Estimating the Economic Consequences of a Port Shutdown: The special role of resilience. Economic Systems Research, 25 (2), 212-32

Savage, H., \& Harvey, P. (2007). Remittances during crises Implications for humanitarian Response. UK: The Overseas Development Institute.

Skidmore, M. (2001). Risk, natural disasters and household savings in a life cycle model. Japan and the World Economy, 13, 15-34.

Skidmore, M. and Toya, H. (2002). Do natural disasters promote growth?. Economic Inquiry, 40 (4), October 2002, 664-687

Suleri, A. Q. \& Savage, K. (2006). Remittances in crises: a case study from Pakistan (The Humanitarian Policy Group Background Paper). UK: The Overseas Development Institute.

Sawada, Y., \& Shimizutani, S. (2007). How do people cope with natural disasters? : Evidence from the Great Hanshin-Awaji (Kobe) earthquake in 1995. Journal of Money, Credit and Banking, 40(1-2).

Webb, G.R., Tierney, K.J., \& Dahlhamer, J. M. (2000). Businesses and disasters: Empirical patterns and unanswered questions. Natural Hazards Review, 1(2): 83-90.

Webb, G.R., Tierney, K.J., \& Dahlhamer. J. M. (2002). Predicting long-term business recovery from disaster: A Comparison of the Loma Prieta Earthquake and Hurricane Andrew. Environmental Hazards, 4, 45-58.

World Bank. (2013). World development report 2014: Risk and opportunity—managing risk for development. Washington, DC: World Bank. 


\subsection{Appendices}

\section{Appendix Table 3-1: Components of household income and consumption}

\begin{tabular}{|c|c|c|c|}
\hline Income components & Description & $\begin{array}{l}19952006 \\
20092012\end{array}$ & 2002 \\
\hline Paid income & $\begin{array}{l}\text { Income from paid employments (wage/salaries, } \\
\text { commissions, bonus, arrears) }\end{array}$ & $\sqrt{ }$ & $\sqrt{ }$ \\
\hline Agricultural Income & $\begin{array}{l}\text { Income from agricultural activities including value of } \\
\text { produce consumed by the household }\end{array}$ & $\sqrt{ }$ & $\sqrt{ }$ \\
\hline $\begin{array}{l}\text { Non-agricultural } \\
\text { Income }\end{array}$ & $\begin{array}{l}\text { Income from non-agricultural activities including value of } \\
\text { products consumed by the household }\end{array}$ & $\sqrt{ }$ & $\sqrt{ }$ \\
\hline Remittance & Local and foreign remittance & $\sqrt{ }$ & $\sqrt{ }$ \\
\hline Transfers & $\begin{array}{l}\text { Receipts of government transfer payment, disability and } \\
\text { relief payments }\end{array}$ & $\sqrt{ }$ & $\sqrt{ }$ \\
\hline Dividends & Dividends and interests & $\sqrt{ }$ & $\sqrt{ }$ \\
\hline Rents \& other income & Property rents and other cash receipts & $\sqrt{ }$ & $\sqrt{ }$ \\
\hline Adhoc income & $\begin{array}{l}\text { Loans taken, sales of assets, withdrawal of savings, income } \\
\text { received from welfare societies, repayment of loans given, } \\
\text { insurance compensations, lottery and other adhoc gains }\end{array}$ & $\sqrt{ }$ & $\mathrm{X}$ \\
\hline Income components & \multicolumn{3}{|c|}{ Description } \\
\hline Food & \multicolumn{3}{|c|}{ Value of consumed food of the household members excluding boarders and servants } \\
\hline Non food & \multicolumn{3}{|c|}{$\begin{array}{l}\text { Household expenditure on housing fuel and light, personal care, health, transport and } \\
\text { communication, education, recreation and cultural activities, nondurable household } \\
\text { goods, household services (laundry, grinding etc.), clothing textiles and footwear, durable } \\
\text { household goods. } \\
\text { Non consumption expenses: Savings, payment of Insurance, debt, income tax, } \\
\text { contributions to trade unions, thrift societies and social security payments (provident } \\
\text { fund), expenses on social activities, donations, loans given. }\end{array}$} \\
\hline Servants & \multicolumn{3}{|c|}{ Expenses on servants' food and non-food consumption. } \\
\hline
\end{tabular}




\section{Appendix Table 3-2: Damage caused by Tsunami, by District}

\begin{tabular}{|c|c|c|c|c|}
\hline District & Deaths & $\begin{array}{l}\text { Displaced } \\
\text { population }\end{array}$ & $\begin{array}{l}\text { Population that } \\
\text { became homeless }\end{array}$ & $\begin{array}{l}\text { Public } \\
\text { infrastructure } \\
\text { damage (Rs. } \\
\text { Million) } \\
\end{array}$ \\
\hline Jaffana & 2640 & 39607 & 20734 & 1716.4 \\
\hline Mulativu & 3000 & 22657 & 22831 & 2166.1 \\
\hline Trincomalee & 1078 & 81643 & 36326 & 3446 \\
\hline Batticaloa & 2840 & 61912 & 70282 & 3208.4 \\
\hline Ampara & 10436 & 75172 & 67707 & 3959.2 \\
\hline Hambantota* & 4500 & 17723 & 8955 & 1296.5 \\
\hline Matara* & 1342 & 13206 & 28860 & 2216.9 \\
\hline Galle* & 4214 & 128077 & 53440 & 4289.9 \\
\hline Kaluthara* & 256 & 27713 & 24855 & 1009.4 \\
\hline Colombo* & 79 & 31239 & 24457 & 235.1 \\
\hline Gampaha* & 6 & 1449 & 4401 & 348.1 \\
\hline Puttlam* & 4 & 66 & 228 & 16.9 \\
\hline Kilinochchi & 0 & 1603 & 1186 & 232.3 \\
\hline Mannar & 0 & 0 & 0 & 11 \\
\hline
\end{tabular}

Note: Districts included in the treatment group are marked with *.

Source: Department of Census and Statistics (2006) 
Appendix Table 3-3: Correlation of disaster damage intensities

\begin{tabular}{|l|l|l|l|l|l|}
\hline $\begin{array}{l}\text { Damage intensity } \\
\text { Variables }\end{array}$ & $\begin{array}{l}\text { Population } \\
\text { in damaged } \\
\text { houses/ } \\
\text { district } \\
\text { population }\end{array}$ & $\begin{array}{l}\text { Affected } \\
\text { GNs/ } \\
\text { total GNs in } \\
\text { each district }\end{array}$ & $\begin{array}{l}\text { Affected DS } \\
\text { population/ } \\
\text { district } \\
\text { population }\end{array}$ & $\begin{array}{l}\text { District } \\
\text { deaths/ } \\
\text { district } \\
\text { population }\end{array}$ & $\begin{array}{l}\text { Displaced } \\
\text { district } \\
\text { population/ } \\
\text { district } \\
\text { population }\end{array}$ \\
\hline $\begin{array}{l}\text { Population in damaged } \\
\text { houses/district } \\
\text { population }\end{array}$ & 1 & & 1 & & \\
\hline $\begin{array}{l}\text { Affected GNs/total GNs in } \\
\text { each district }\end{array}$ & 0.9782 & 1 & 0.7784 & 1 & \\
\hline $\begin{array}{l}\text { Affected DS } \\
\text { population/district } \\
\text { population }\end{array}$ & 0.7433 & 0.6276 & 0.5179 & 1 & \\
\hline $\begin{array}{l}\text { District deaths/district } \\
\text { population }\end{array}$ & 0.6293 & 0.9252 & 0.6039 & 0.6311 & 1 \\
\hline $\begin{array}{l}\text { Displaced district } \\
\text { population/district } \\
\text { population }\end{array}$ & 0.8535 & & & & \\
\hline
\end{tabular}

\section{Appendix Table 3-4: IQR test for severe outliers}

\begin{tabular}{|l|l|l|l|l|}
\hline $\begin{array}{l}\text { Explanatory } \\
\text { Variable }\end{array}$ & Income & Log of Income & Consumption & $\begin{array}{l}\text { Log of } \\
\text { consumption }\end{array}$ \\
\hline Low values & $0.19 \%$ & $0.49 \%$ & $0.00 \%$ & $0.1 \%$ \\
\hline High values & $3.83 \%$ & $0.11 \%$ & $2.97 \%$ & $0.00 \%$ \\
\hline
\end{tabular}




\section{Appendix Table 3-5: Determinants of Income}

\begin{tabular}{|c|c|c|c|c|c|}
\hline Variables & Coeff. & $\begin{array}{l}\text { Robust Std. } \\
\text { (Clustered) }\end{array}$ & Variables & Coeff. & $\begin{array}{l}\text { Robust Std. } \\
\text { (Clustered) }\end{array}$ \\
\hline year_2002 & -1234 & $23^{* * *}$ & CMB(Colombo) & 4347 & $91^{* * *}$ \\
\hline year_2006 & -908 & $39^{* * *}$ & GMP(Gampaha) & 1435 & $44^{* * *}$ \\
\hline year_2009 & -2196 & $23^{* * *}$ & KTR(Kalutara) & -472 & $42^{* * *}$ \\
\hline year_2012 & 8287 & $134^{* * *}$ & KDN(Kandy) & 527 & $22^{* * *}$ \\
\hline Sex(dummy) & -154 & $45^{* * *}$ & NEL(Nuwara Eliya) & -1014 & $46^{* * *}$ \\
\hline Age & 1 & 2 & GLL(Galle) & -417 & $43^{* * *}$ \\
\hline Level of education & 21 & $11^{*}$ & MTR(Matara) & -925 & $46^{* * *}$ \\
\hline Widowed and Divorced (dummy) & -103 & 102 & HBT(Hambantota) & -3815 & $321^{* * *}$ \\
\hline HH size & 22 & 23 & KRN(Kurunegala) & -3676 & $323^{* * *}$ \\
\hline Ownership of house & 134 & $74^{*}$ & PTLM(Puttlam) & -5042 & $293^{* * *}$ \\
\hline Total area of crop cultivated & .12 & .07 & PLNR(Polonnaruwa) & -5500 & $331^{* * *}$ \\
\hline Sinhalese(dummy) & -80 & 126 & ANUR(Anuradhapura) & -6322 & $330^{* * *}$ \\
\hline Other ethnic(dummy) & -387 & 612 & BDL(Badulla) & -7099 & $320^{* * *}$ \\
\hline Transfer payment(dummy) & -2581 & $349^{* * *}$ & MONR(Moneragala) & -6453 & $334^{* * *}$ \\
\hline $\begin{array}{l}\text { Pension \& Disability } \\
\text { payment(dummy) }\end{array}$ & 2578 & $364^{* * *}$ & RTN(Ratnapura) & -7018 & $333^{* * *}$ \\
\hline Remittance-local(dummy) & 324 & $127^{* * *}$ & KGL(Kegalle) & -7196 & $329^{* * *}$ \\
\hline Remittance-foreign(dummy) & 2025 & $181^{* * *}$ & & & \\
\hline employed(dummy) & -156 & 96 & & & \\
\hline unemployed(dummy) & -350 & 305 & & & \\
\hline Non paid employed(dummy) & -94 & 77 & & & \\
\hline Rural sector (dummy) & -232 & $93^{* * *}$ & & & \\
\hline Estate sector(dummy) & -484 & $174^{* * *}$ & & & \\
\hline Constant & 7977 & $523^{* * *}$ & & & \\
\hline
\end{tabular}

Notes: Robust standard errors in bracket. ${ }^{* * *},{ }^{* *},{ }^{*}$, stand for significance at $1 \%, 5 \%$ and $10 \%$ respectively. This regression controlled for the district year fixed effects. 


\section{Appendix Table 3-6: Determinants of consumption}

\begin{tabular}{|c|c|c|c|c|c|}
\hline Variable & Coefficient & $\begin{array}{l}\text { Robust Std. } \\
\text { (Clustered) }\end{array}$ & Variable & Coefficient & $\begin{array}{l}\text { Robust Std. } \\
\text { (Clustered) }\end{array}$ \\
\hline year_2002 & -405 & $26^{* * *}$ & CMB(Colombo) & 6280 & $387^{* * *}$ \\
\hline year_2006 & -334 & 37 & GMP(Gampaha) & 4648 & $243^{* * *}$ \\
\hline year_2009 & 3227 & 244 & KTR(Kalutara) & 2241 & $182^{* * *}$ \\
\hline year_2012 & 11889 & $149^{* * *}$ & KDN(Kandy) & 1340 & $146^{* * *}$ \\
\hline Sex(dummy) & 137 & 108 & MTL(Matale) & 948 & $107^{* * *}$ \\
\hline Age & 13 & $6^{* *}$ & NEL(Nuwara Eliya) & 2552 & $340^{* * *}$ \\
\hline Level of education & 264 & $91^{* * *}$ & GLL(Galle) & 2658 & $97^{* * *}$ \\
\hline Widowed and Divorced(dummy) & -511 & $130^{* * *}$ & MTR(Matara) & 2498 & $107^{* * *}$ \\
\hline HH Size & 286 & $51^{* * *}$ & HBT(Hambantota) & 3558 & $30^{* * *}$ \\
\hline Ownership of house(dummy) & 1641 & $248^{* * *}$ & KRN(Kurunegala) & 1360 & $55^{* * *}$ \\
\hline Total area of crop cultivated & .04 & .04 & PTLM(Puttlam) & 1603 & $126^{* * *}$ \\
\hline Sinhalese(dummy) & 274 & 196 & PLNR(Polonnaruwa) & 2587 & $89^{* * *}$ \\
\hline Other ethnic(dummy) & -179 & 549 & ANUR(Anuradhapura) & 1225 & $96^{* * *}$ \\
\hline Transfer payment & -.08 & .05 & BDL(Badulla) & 501 & $96^{* * *}$ \\
\hline $\begin{array}{l}\text { Pension \& Disability(dummy) } \\
\text { payment(dummy) }\end{array}$ & .07 & $.01^{* *}$ & RTN(Ratnapura) & 1136 & $63^{* * *}$ \\
\hline Remittance-local(dummy) & -.00 & .001 & KGL(Kegale) & 1198 & $86^{* * *}$ \\
\hline Remittance-foreign(dummy) & .001 & $.0004^{* *}$ & & & \\
\hline employed(dummy) & -106 & 159 & & & \\
\hline unemployed(dummy) & 37 & 452 & & & \\
\hline Non paid employed(dummy) & 94 & 108 & & & \\
\hline Rural sector (dummy) & -1852 & $185^{* * *}$ & & & \\
\hline Estate sector(dummy) & -1819 & $582^{* * *}$ & & & \\
\hline Constant & 1141 & 858 & & & \\
\hline
\end{tabular}

Notes: Robust standard errors in bracket. ${ }^{* *},{ }^{* *},{ }^{*}$, stand for significance at $1 \%, 5 \%$ and $10 \%$ respectively. This regression controlled for the district year fixed effects. 


\section{Appendix Table 3-7: Impact on Income and Consumption excluding year 2002}

\section{data}

\begin{tabular}{lccc}
\hline Dependent variables & $\begin{array}{c}\text { Monthly income (Rs.) } \\
\text { (Exclude year 2002 } \\
\text { data) }\end{array}$ & $\begin{array}{c}\text { Monthly household } \\
\text { consumption (Rs.) } \\
\text { Independent Variables }\end{array}$ & $\begin{array}{c}\text { Ad-hoc income } \\
\text { (Excluding year 2002 } \\
\text { data) }\end{array}$ \\
year_2006 & -2547 & data) & -2303 \\
year_2009 & $(799)^{* * *}$ & 2941 & $(457)^{* * *}$ \\
& -3024 & 2354 & $(1266)^{* * *}$ \\
year_2012 & $(1069)^{* * *}$ & $(182)^{* * *}$ & -2229 \\
& 145 & 11323 & $(1352)^{* * *}$ \\
Treatment*2006 & $(1326)$ & $(618)^{* * *}$ & -1098 \\
& $\mathbf{3 3 4 5}$ & $\mathbf{1 0 7 7}$ & $(717)$ \\
Treatment*2009 & $(1538)^{* *}$ & $(524)^{* *}$ & -3859 \\
& 1535 & 12 & $(2677)$ \\
Treatment*2012 & $(1958)$ & $(417)$ & -4463 \\
& $\mathbf{1 1 9 9 4}$ & $\mathbf{2 7 0 4}$ & $(2803)$ \\
District fixed effects & $(2507)^{* * *}$ & $(1264)^{* *}$ & -2904 \\
& Yes & Yes & $(1946)$ \\
Constant & & & No \\
& $(729)$ & 3616 & 887 \\
\hline R-squared & 0.52 & $(960)^{* * *}$ & $(795)$ \\
Number of observations & 67498 & 0.27 & 0.19 \\
\hline
\end{tabular}

Notes: Robust standard errors in bracket. ***, **, *, stand for significance at $1 \%, 5 \%$ and $10 \%$ respectively. Model estimations controlled for household covariates i.e. sex, age, years of education, ethnicity of the household head, household size and the district and year fixed effects. 


\section{Appendix Table 3-8: Impact on income using different Treatment Intensities (model estimated without controlling for district time trend)}

\begin{tabular}{|c|c|c|c|c|c|}
\hline & $\begin{array}{c}\text { Affected } \\
\text { GN/Total } \\
\text { District GNs }\end{array}$ & $\begin{array}{c}\text { Population in } \\
\text { destroyed } \& \\
\text { damaged houses/ } \\
\text { District } \\
\text { population }\end{array}$ & $\begin{array}{c}\text { Population in } \\
\text { affected } \\
\text { DS/District } \\
\text { Population }\end{array}$ & $\begin{array}{c}\text { Total deaths/ } \\
\text { District Population }\end{array}$ & $\begin{array}{c}\text { Displaced } \\
\text { population } \\
\text { /District population }\end{array}$ \\
\hline year_2002 & $\begin{array}{l}-192 \\
(492)\end{array}$ & $\begin{array}{c}-182 \\
(487)\end{array}$ & $\begin{array}{l}-275 \\
(537)\end{array}$ & $\begin{array}{l}-184 \\
(477)\end{array}$ & $\begin{array}{l}-180 \\
(481)\end{array}$ \\
\hline year_2006 & $\begin{array}{c}2641 \\
(1891)\end{array}$ & $\begin{array}{c}3009 \\
(2025)\end{array}$ & $\begin{array}{c}528 \\
(1591)\end{array}$ & $\begin{array}{c}3652 \\
(2007)^{*}\end{array}$ & $\begin{array}{c}3283 \\
(1960)^{*}\end{array}$ \\
\hline year_2009 & $\begin{array}{c}1466 \\
(1437)\end{array}$ & $\begin{array}{c}1742 \\
(1534)\end{array}$ & $\begin{array}{c}-124 \\
(1217)\end{array}$ & $\begin{array}{c}2273 \\
(1522)^{* * *}\end{array}$ & $\begin{array}{c}2015 \\
(1486)\end{array}$ \\
\hline year_2012 & $\begin{array}{c}6658 \\
(3357)^{* * *}\end{array}$ & $\begin{array}{c}7333 \\
(3641)^{* *}\end{array}$ & $\begin{array}{c}2578 \\
(2561)\end{array}$ & $\begin{array}{c}8657 \\
(3714)^{* *}\end{array}$ & $\begin{array}{c}8131 \\
(3567)^{* * *}\end{array}$ \\
\hline Treatment*2006 & $\begin{array}{c}25785 \\
(21176)\end{array}$ & $\begin{array}{c}60687 \\
(57327)\end{array}$ & $\begin{array}{c}17287 \\
(6507)^{* * *}\end{array}$ & $\begin{array}{l}-172018 \\
(349935)\end{array}$ & $\begin{array}{c}17775 \\
(22446)\end{array}$ \\
\hline & $\begin{array}{c}{[-27716,211812]} \\
(0.10)\end{array}$ & $\begin{array}{c}{[-75727,573302]} \\
(0.29)\end{array}$ & $\begin{array}{c}{[1744,30775]} \\
(0.02)\end{array}$ & $\begin{array}{c}{[-5478150,4099263]} \\
(0.66)\end{array}$ & $\begin{array}{c}{[-260536,436894]} \\
(0.41)\end{array}$ \\
\hline Treatment*2009 & $\begin{array}{c}23960 \\
(17169)\end{array}$ & $\begin{array}{c}62967 \\
(47367)\end{array}$ & $\begin{array}{c}14165 \\
(4191)^{* * *}\end{array}$ & $\begin{array}{c}11219 \\
(259265)\end{array}$ & $\begin{array}{c}19394 \\
(19166)\end{array}$ \\
\hline & $\begin{array}{c}{[-20297,163904]} \\
(0.07)\end{array}$ & $\begin{array}{c}{[-60948,480550]} \\
(0.18)\end{array}$ & $\begin{array}{c}{[4317,23173]} \\
(0.000)\end{array}$ & $\begin{array}{c}{[-3703418} \\
3359278]] \\
(0.97)\end{array}$ & $\begin{array}{c}{[-238702,380537]} \\
(0.30)\end{array}$ \\
\hline Treatment*2012 & $\begin{array}{c}66334 \\
(45070)\end{array}$ & $\begin{array}{c}183691 \\
(123073)\end{array}$ & $\begin{array}{c}37834 \\
(9834)^{* * *}\end{array}$ & $\begin{array}{c}346517 \\
(627625)\end{array}$ & $\begin{array}{c}55869 \\
(51219)\end{array}$ \\
\hline & $\begin{array}{c}{[-73717,418260]} \\
(0.06\end{array}$ & $\begin{array}{c}{[-127116,} \\
1266395] \\
(0.13)\end{array}$ & $\begin{array}{c}{[14388,57459]} \\
(0.00)\end{array}$ & $\begin{array}{c}{[-8989093,8274971]} \\
(0.65)\end{array}$ & $\begin{array}{c}{[-690061,1014734]} \\
(0.26)\end{array}$ \\
\hline Constant & $\begin{array}{l}-2932 \\
(1397)\end{array}$ & $\begin{array}{c}-3215 \\
(1493)^{* *}\end{array}$ & $\begin{array}{l}-1193 \\
(1127)\end{array}$ & $\begin{array}{c}-3773 \\
(1461)^{* * *}\end{array}$ & $\begin{array}{c}-3497 \\
(1450)^{* * *}\end{array}$ \\
\hline $\begin{array}{l}\text { R-squared } \\
\text { N. of obs. }\end{array}$ & $\begin{array}{c}0.45 \\
84393\end{array}$ & $\begin{array}{c}0.44 \\
84393\end{array}$ & $\begin{array}{c}0.48 \\
84393\end{array}$ & $\begin{array}{c}0.44 \\
84393\end{array}$ & $\begin{array}{c}0.44 \\
84393\end{array}$ \\
\hline
\end{tabular}

Note: Robust standard errors in bracket. $* * *, * *, *$, stand for significance at $1 \%, 5 \%$ and $10 \%$ respectively. Model estimations controlled for household covariates i.e. sex, age, years of education, ethnicity of the household head, and household size and the district and year fixed effects. 


\section{Appendix Table 3-9: Impact on Consumption using different treatment Intensities (model without controlling for district time trend)}

\begin{tabular}{|c|c|c|c|c|c|}
\hline & $\begin{array}{c}\text { Affected } \\
\text { GN/Total } \\
\text { District GNs }\end{array}$ & $\begin{array}{c}\text { Population in } \\
\text { destroyed\& } \\
\text { damaged } \\
\text { houses/ } \\
\text { District } \\
\text { population }\end{array}$ & $\begin{array}{c}\text { Population in } \\
\text { affected } \\
\text { DS/District } \\
\text { Population }\end{array}$ & $\begin{array}{c}\text { Total deaths/ } \\
\text { District Population }\end{array}$ & $\begin{array}{l}\text { Displaced population } \\
\text { /District Population }\end{array}$ \\
\hline year_2002 & $\begin{array}{c}477 \\
(203)^{* *}\end{array}$ & $\begin{array}{c}477 \\
(204)^{* *}\end{array}$ & $\begin{array}{c}466 \\
(204)^{* *}\end{array}$ & $\begin{array}{c}479 \\
(203)^{* * *}\end{array}$ & $\begin{array}{c}477 \\
(203)\end{array}$ \\
\hline year_2006 & $\begin{array}{c}2975 \\
(289)^{* * *}\end{array}$ & $\begin{array}{c}3017 \\
(282)^{* * *}\end{array}$ & $\begin{array}{c}2825 \\
(374)^{* * *}\end{array}$ & $\begin{array}{c}3249 \\
(269)^{* * *}\end{array}$ & $\begin{array}{c}3200 \\
(252)^{* * *}\end{array}$ \\
\hline year_2009 & $\begin{array}{l}2432 \\
(194)\end{array}$ & $\begin{array}{c}2425 \\
(192)^{* * *}\end{array}$ & $\begin{array}{c}2294 \\
(190)^{* * *}\end{array}$ & $\begin{array}{c}2380 \\
(203)^{* * *}\end{array}$ & $\begin{array}{c}2423 \\
(192)^{* * *}\end{array}$ \\
\hline year_2012 & $\begin{array}{l}12577 \\
(690)\end{array}$ & $\begin{array}{c}12674 \\
(706)^{* * *}\end{array}$ & $\begin{array}{c}11558 \\
(628)^{* * *}\end{array}$ & $\begin{array}{l}12708 \\
(709)^{* *}\end{array}$ & $\begin{array}{c}12721 \\
(691)^{* * *}\end{array}$ \\
\hline Treatment*2006 & $\begin{array}{c}12745 \\
(3698)^{* * *}\end{array}$ & $\begin{array}{c}46236 \\
(10147)^{* * *}\end{array}$ & $\begin{array}{c}3536 \\
(981)^{* * *}\end{array}$ & $\begin{array}{c}289475 \\
(83308)^{* * *}\end{array}$ & $\begin{array}{c}16559 \\
(4765)^{* * *}\end{array}$ \\
\hline & $\begin{array}{c}{[-6642,35891]} \\
(0.06)\end{array}$ & $\begin{array}{c}{[10691,111083]} \\
(0.04)\end{array}$ & $\begin{array}{c}{[1073,6568]} \\
(0.02)\end{array}$ & $\begin{array}{c}{[-1716364,1100468]} \\
(0.10)\end{array}$ & $\begin{array}{c}{[-62426,94831]} \\
(0.42)\end{array}$ \\
\hline Treatment*2009 & $\begin{array}{l}-3036 \\
(2273)\end{array}$ & $\begin{array}{r}-11266 \\
(8047)\end{array}$ & $\begin{array}{c}186 \\
(767)\end{array}$ & $\begin{array}{c}-72567 \\
(84694)\end{array}$ & $\begin{array}{c}-6704 \\
(2154)^{* * *}\end{array}$ \\
\hline & $\begin{array}{c}{[-6128,11829]} \\
(0.76)\end{array}$ & $\begin{array}{c}{[-24081,39864]} \\
(0.58)\end{array}$ & $\begin{array}{c}{[-2272,1566]} \\
(0.8)\end{array}$ & $\begin{array}{c}{[-381155,1731910]} \\
(0.56)\end{array}$ & $\begin{array}{c}{[-41156,29181]} \\
(0.78)\end{array}$ \\
\hline Treatment*2012 & $\begin{array}{c}-1327 \\
(12194)\end{array}$ & $\begin{array}{l}-16496 \\
(36316)\end{array}$ & $\begin{array}{c}5887 \\
(3379)^{*}\end{array}$ & $\begin{array}{c}251726 \\
(258888)\end{array}$ & $-13643(12203)$ \\
\hline & $\begin{array}{c}{[-17269,85234]} \\
(0.96)\end{array}$ & $\begin{array}{c}{[-69743,} \\
250598] \\
(0.79)\end{array}$ & $\begin{array}{c}{[-4904,11836]} \\
(0.25)\end{array}$ & $\begin{array}{c}{[-1825516,4903336]} \\
(0.37)\end{array}$ & $\begin{array}{c}{[-202991,203593]} \\
(0.93)\end{array}$ \\
\hline Constant & $\begin{array}{c}-781 \\
(1169)\end{array}$ & $\begin{array}{c}800 \\
(1191)\end{array}$ & $\begin{array}{c}-498 \\
(1025)\end{array}$ & $\begin{array}{c}-783 \\
(1228)\end{array}$ & $\begin{array}{c}-3497 \\
(1450)^{* * *}\end{array}$ \\
\hline $\begin{array}{l}\text { R-squared } \\
\text { N. of obs. }\end{array}$ & $\begin{array}{c}0.28 \\
84393\end{array}$ & $\begin{array}{c}0.28 \\
84393\end{array}$ & $\begin{array}{c}0.28 \\
84393\end{array}$ & $\begin{array}{c}0.28 \\
84393\end{array}$ & $\begin{array}{c}0.28 \\
84393\end{array}$ \\
\hline
\end{tabular}

Note: Robust standard errors in bracket. ***,**,*, stand for significance at 1\%, 5\% and 10\% respectively. Model estimations controlled for household covariates i.e. sex, age, years of education, ethnicity of the household head, and household size and the district and year fixed effects. 


\section{Appendix Table 3-10: Impact on income using different Treatment Intensities after controlling for district linear time trends}

\begin{tabular}{|c|c|c|c|c|c|}
\hline & $\begin{array}{c}\text { Affected } \\
\text { GN/Total } \\
\text { District GNs }\end{array}$ & $\begin{array}{c}\text { Population in } \\
\text { destroyed\& } \\
\text { damaged } \\
\text { houses/ } \\
\text { District } \\
\text { population }\end{array}$ & $\begin{array}{l}\text { Population in } \\
\text { affected } \\
\text { DS/District } \\
\text { Population }\end{array}$ & $\begin{array}{c}\text { Total deaths/ } \\
\text { District Population }\end{array}$ & $\begin{array}{c}\text { Displaced } \\
\text { population } \\
\text { /District population }\end{array}$ \\
\hline \multirow[t]{2}{*}{ Treatment*2006 } & $\begin{array}{c}22293 \\
(24336)\end{array}$ & $\begin{array}{c}49365 \\
(60576)\end{array}$ & $\begin{array}{c}18450 \\
(8805)^{* *}\end{array}$ & $\begin{array}{l}-300548 \\
(375620)\end{array}$ & $\begin{array}{c}7724 \\
(23010)\end{array}$ \\
\hline & $\begin{array}{c}{[-6634,244766]} \\
(0.25)\end{array}$ & $\begin{array}{c}{[-41462,749319]} \\
(0.36)\end{array}$ & $\begin{array}{c}{[-775.8,38618]} \\
(0.07)\end{array}$ & $\begin{array}{c}{[-5701833,4064281]} \\
(0.52)\end{array}$ & $\begin{array}{c}{[-261458,512998]} \\
(0.71)\end{array}$ \\
\hline \multirow[t]{2}{*}{ Treatment*2009 } & $\begin{array}{c}18345 \\
(21712)\end{array}$ & $\begin{array}{c}45111 \\
(55060)\end{array}$ & $\begin{array}{c}15669 \\
(7520)^{* *}\end{array}$ & $\begin{array}{l}-174728 \\
(323320)\end{array}$ & $\begin{array}{c}4656 \\
(20700)\end{array}$ \\
\hline & $\begin{array}{c}{[-7609,204412]} \\
(0.31)\end{array}$ & $\begin{array}{c}{[-34551,622653]} \\
(0.42)\end{array}$ & $\begin{array}{c}{[-168,32954]} \\
(0.06)^{* * *}\end{array}$ & $\begin{array}{c}{[-4104551,3460502]} \\
(0.68)\end{array}$ & $\begin{array}{c}{[-246188,504193]} \\
(0.79)\end{array}$ \\
\hline \multirow[t]{2}{*}{ Treatment*2012 } & $\begin{array}{c}58924 \\
(50916)\end{array}$ & $\begin{array}{c}159466 \\
(130303)\end{array}$ & $\begin{array}{c}39816 \\
(13952)^{* * *}\end{array}$ & $\begin{array}{c}97763 \\
(695510)\end{array}$ & $\begin{array}{c}36205 \\
(52564)\end{array}$ \\
\hline & $\begin{array}{c}{[-6304,492296]} \\
(0.12)\end{array}$ & $\begin{array}{c}{[-46777,1523361]} \\
(0.18)\end{array}$ & $\begin{array}{c}{[8449,70611]} \\
(0.001)\end{array}$ & $\begin{array}{c}{[-7665752,7797806]} \\
(0.91)\end{array}$ & $\begin{array}{c}{[-671816,1099374]} \\
(0.44)\end{array}$ \\
\hline R-squared & 0.29 & 0.51 & 0.52 & 0.51 & 0.51 \\
\hline
\end{tabular}

Note: Robust standard errors in bracket. ${ }^{* *}, * *, *$, stand for significance at $1 \%, 5 \%$ and $10 \%$ respectively. Model estimations controlled for household covariates i.e. sex, age, years of education, ethnicity of the household head, and household size and the district and year fixed effects.

\section{Appendix Table 3-11: Impact on Consumption using different Treatment Intensities after controlling for district linear time trends}

\begin{tabular}{|c|c|c|c|c|c|}
\hline & $\begin{array}{c}\text { Affected } \\
\text { GN/Total District } \\
\text { GNs }\end{array}$ & $\begin{array}{c}\text { Population in } \\
\text { destroyed\& } \\
\text { damaged } \\
\text { houses/ } \\
\text { District } \\
\text { population }\end{array}$ & $\begin{array}{l}\text { Population in } \\
\text { affected } \\
\text { DS/District } \\
\text { Population }\end{array}$ & $\begin{array}{c}\text { Total deaths/ } \\
\text { District Population }\end{array}$ & $\begin{array}{c}\text { Displaced } \\
\text { population } \\
\text { /District } \\
\text { population }\end{array}$ \\
\hline \multirow[t]{2}{*}{ Treatment*2006 } & $\begin{array}{c}17612 \\
(4288)^{* * *}\end{array}$ & $\begin{array}{c}65458 \\
(13721)^{* * *}\end{array}$ & $\begin{array}{c}4231 \\
(1737)^{* * *}\end{array}$ & $\begin{array}{c}634340 \\
(71569)^{* * *}\end{array}$ & $\begin{array}{c}25183 \\
(6284)^{* * *}\end{array}$ \\
\hline & $\begin{array}{c}{[4914,39272]} \\
(0.03)\end{array}$ & $\begin{array}{c}{[14169,144896]} \\
(0.04)\end{array}$ & $\begin{array}{c}{[-208.1,9566]} \\
(0.05)\end{array}$ & $\begin{array}{c}{[-419923,1613712]} \\
(0.08)\end{array}$ & $\begin{array}{c}{[-79418,146783]} \\
(0.22)\end{array}$ \\
\hline \multirow[t]{2}{*}{ Treatment*2009 } & $\begin{array}{c}3573 \\
(3214)\end{array}$ & $\begin{array}{c}15095 \\
(12536)\end{array}$ & $\begin{array}{c}1091 \\
(1426)\end{array}$ & $\begin{array}{c}412590 \\
(130768)^{* * *}\end{array}$ & $\begin{array}{c}5248 \\
(4643)\end{array}$ \\
\hline & $\begin{array}{c}{[-2799,23986]} \\
(0.17)\end{array}$ & $\begin{array}{c}{[-18199,121534]} \\
(0.15)\end{array}$ & $\begin{array}{c}{[-3046,5452]} \\
(0.50)\end{array}$ & $\begin{array}{c}{[3284,3160148]} \\
(0.05)\end{array}$ & $\begin{array}{c}{[-9349,106615]} \\
(0.13)\end{array}$ \\
\hline \multirow[t]{2}{*}{ Treatment*2012 } & $\begin{array}{c}7192 \\
(11133)\end{array}$ & $\begin{array}{c}17374 \\
(31855)\end{array}$ & $\begin{array}{c}7068 \\
(2773)^{* * *}\end{array}$ & $\begin{array}{c}370923 \\
(307853)\end{array}$ & $\begin{array}{c}1706 \\
(13137)\end{array}$ \\
\hline & $\begin{array}{c}{[-8167,97078]} \\
(0.59) \\
\end{array}$ & $\begin{array}{c}{[-32838,322056]} \\
(0.64)\end{array}$ & $\begin{array}{c}{[-667.4,12515]} \\
(0.10) \\
\end{array}$ & $\begin{array}{c}{[-924930,6817665]} \\
(0.72) \\
\end{array}$ & $\begin{array}{c}{[-216915,224750]} \\
(0.94)\end{array}$ \\
\hline R-squared & 0.29 & 0.29 & 0.29 & 0.29 & 0.29 \\
\hline
\end{tabular}

Note: Robust standard errors in bracket. ${ }^{* *}, * *, *$, stand for significance at $1 \%, 5 \%$ and $10 \%$ respectively. Model estimations controlled for household covariates i.e. sex, age, years of education, ethnicity of the household head, and household size and the district and year fixed effects. 


\section{Appendix Table 3-12: Flexible model with Treatment dummy and controlling for}

\section{district time trend}

\begin{tabular}{|c|c|c|c|c|c|c|c|c|}
\hline \multirow[t]{3}{*}{ Variable } & \multicolumn{4}{|c|}{ Linear time trend } & \multicolumn{4}{|c|}{ Quadratics time trend } \\
\hline & \multicolumn{2}{|c|}{ Income } & \multicolumn{2}{|c|}{ Consumption } & \multicolumn{2}{|c|}{ Income } & \multicolumn{2}{|c|}{ Consumption } \\
\hline & Coefficient & S.E & Coefficient & S. E & Coefficient & S. E & Coefficient & S.E \\
\hline Treatment*2006 & 7022 & $(2898)^{* * *}$ & 1343 & $(735)^{*}$ & 7015 & $(3487)^{* *}$ & 1407 & $(1054)$ \\
\hline Treatment*2009 & 5787 & $(2474)^{* * *}$ & 333 & $(500)$ & 5773 & $(4086)$ & 533 & $(1320)$ \\
\hline Treatment*2012 & 15066 & $(4802)^{* * *}$ & 2981 & $(925)^{* * *}$ & 15040 & $(7262)^{* *}$ & 3324 & $(1892)^{*}$ \\
\hline Colombo & 623 & $(277)^{* * *}$ & 745 & $(50)^{* * *}$ & 39 & $(26)$ & 44 & $(7)^{* * *}$ \\
\hline Gampaha & 378 & $(276)$ & 709 & $(52)^{* * *}$ & 21 & $(26)$ & 41 & $(7)^{* * *}$ \\
\hline Kalutara & 65 & (284) & 762 & $(54)^{* * *}$ & 4 & (26) & 43 & $(7)^{* * *}$ \\
\hline Kandy & 422 & $(13)^{* * * *}$ & 750 & $(11)^{* * *}$ & 26 & (1) $)^{* * *}$ & 44 & $(1)^{* * *}$ \\
\hline Matale & 468 & $(13)^{* * *}$ & 702 & $(10)^{* * *}$ & 28 & (1) $)^{* * *}$ & 42 & (1) *** \\
\hline Nuwara Eliya & 516 & $(14)^{* * * *}$ & 637 & $(16)^{* * * *}$ & 30 & (1) ${ }^{* * * *}$ & 38 & $(1)^{* * *}$ \\
\hline Galle & -265 & $(282)$ & 411 & $(56)^{* * *}$ & -17 & (30) & 21 & $(7)^{* * *}$ \\
\hline Matara & -368 & (282) & 478 & $(56)^{* * *}$ & -21 & (26) & 25 & $(7)^{* * *}$ \\
\hline Hambantota & -258 & (283) & 537 & $(57)^{* * *}$ & -14 & $(26)$ & 31 & (7) $)^{* * *}$ \\
\hline Kurunegala & -263 & $(12)^{* * * *}$ & 699 & $(13)^{* * *}$ & -15 & $\left((1)^{* * *}\right.$ & 41 & $(1)^{* * *}$ \\
\hline Puttlam & -965 & $(286)^{* * *}$ & 598 & $(54)^{* * *}$ & -56 & $(26)^{* * * *}$ & 34 & $(7)^{* * *}$ \\
\hline Anuradhapura & -49 & $(12)^{* * *}$ & 645 & $(8)^{* * *}$ & -3 & $(1)^{* * *}$ & 38 & $(1)^{* * *}$ \\
\hline Badulla & -5 & (13) & 672 & $(14)^{* * *}$ & -1 & (1) & 39 & $(1)^{* * *}$ \\
\hline Moneragala & -39 & $(13)^{* * * *}$ & 425 & $(11)^{* * * *}$ & -2 & $(0.6)^{* * * *}$ & 23 & $(1)^{* * * *}$ \\
\hline Polonnaruwa & -88 & $(12)^{* * *}$ & 689 & $(9)^{* * *}$ & -4 & $(1)^{* * *}$ & 43 & $(1)^{* * *}$ \\
\hline Ratnapura & -12 & (12) & 544 & $(10)^{* * *}$ & -1 & $(0.6)^{*}$ & 32 & $(1)^{* * *}$ \\
\hline Kegalle & -1 & (14) & 642 & $(12)^{* * *}$ & -1 & (1) & 38 & $(1)^{* * *}$ \\
\hline Constant & 1497 & $(568)^{* * *}$ & 2062 & $(1122)^{*}$ & 693 & (570) & 1890 & $(1054)^{*}$ \\
\hline R2 & 0.52 & & 0.29 & & 0.52 & & 0.29 & \\
\hline Observations & 84393 & & 84393 & & 84393 & & 84393 & \\
\hline
\end{tabular}

Note: Robust standard errors in bracket. ${ }^{* *}, * *, *$, stand for significance at $1 \%, 5 \%$ and $10 \%$ respectively. Model estimations controlled for household covariates i.e. sex, age, years of education, ethnicity of the household head, and household size. The models also controlled for district fixed effects, year fixed effects, and district year fixed effects, district time trend. 
Online Appendix Table 3-13: Flexible model with District proportion of population as treatment variable and controlling for district time trend

\begin{tabular}{|c|c|c|c|c|c|c|c|c|}
\hline \multirow[t]{3}{*}{ Variable } & \multicolumn{4}{|c|}{ Linear time trend } & \multicolumn{4}{|c|}{ Quadratics time trend } \\
\hline & \multicolumn{2}{|l|}{ Income } & \multicolumn{2}{|c|}{ Consumption } & \multicolumn{2}{|l|}{ Income } & \multicolumn{2}{|c|}{ Consumption } \\
\hline & Coeff. & S. E & Coeff & S. E. & Coeff. & S. E & Coeff. & S. E \\
\hline Treatment*2006 & 18450 & $(8805)^{* *}$ & 4232 & $(1737)^{*}$ & 19202 & $(10953)^{*}$ & 4691 & $(2690)^{*}$ \\
\hline Treatment*2009 & 15669 & $(7520)^{* *}$ & 1092 & $(1426)$ & 17651 & (12392) & 2333 & (3718) \\
\hline Treatment*2012 & 39816 & $(13952)^{* * *}$ & 7068 & $(2773)^{* * *}$ & 43362 & $(22206)^{* *}$ & 9247 & $(5226)^{*}$ \\
\hline Colombo & 452 & $(376)$ & 733 & $(65)^{* * *}$ & 23 & (36) & 41 & $(9)^{* * *}$ \\
\hline Gampaha & 873 & $(124)^{* * *}$ & 803 & $(25)^{* * *}$ & 50 & $(12)^{* * *}$ & 47 & (3) $)^{* * *}$ \\
\hline Kalutara & -26 & $(352)$ & 763 & $(65)^{* * *}$ & -7 & (33) & 41 & $(8)^{* * *}$ \\
\hline Kandy & 427 & $(13)^{* * *}$ & 755 & $(11)^{* * * *}$ & 26 & $(1)^{* * *}$ & 44 & $(1)^{* * *}$ \\
\hline Matale & 473 & $(13)^{* * *}$ & 707 & $(11)^{* * *}$ & 29 & $(1)^{* * *}$ & 42 & $(1)^{* * *}$ \\
\hline Nuwara Eliya & 523 & $(16)^{* * *}$ & 643 & $(16)^{* * *}$ & 30 & $(1)^{* * *}$ & 38 & (1) ( $^{* * *}$ \\
\hline Galle & -421 & (374) & 401 & $(70)^{* * *}$ & -33 & (35) & 18 & $(9)^{* *}$ \\
\hline Matara & -304 & (291) & 504 & $(56)^{* * *}$ & -22 & (28) & 26 & (7) $)^{* * *}$ \\
\hline Hambantota & -416 & $(375)$ & 527 & $(71)^{* * *}$ & -29 & (36) & 28 & (9) $)^{* * *}$ \\
\hline Kurunegala & -258 & $(13)^{* * *}$ & 704 & $(14)^{* * *}$ & -15 & $\left((1)^{* * *}\right.$ & 41 & $(1)^{* * *}$ \\
\hline Puttlam & -339 & $(85)^{* * *}$ & 714 & $(20)^{* * *}$ & -56 & $(26)^{* * *}$ & 42 & $(2)^{* * *}$ \\
\hline Anuradhapura & -45 & $(12)^{* * *}$ & 650 & $(9)^{* * *}$ & -20 & $(7)^{* * *}$ & 38 & (1) $)^{* * *}$ \\
\hline Badulla & -0.33 & (12) & 677 & $(15)^{* * *}$ & -0.4 & (1) & 39 & (1) ( $* * *^{*}$ \\
\hline Moneragala & -35 & $(13)^{* * *}$ & 425 & $(11)^{* * *}$ & -2 & $(0.8)^{* * *}$ & 23 & (1) $)^{* * *}$ \\
\hline Polonnaruwa & -84 & $(13)^{* * *}$ & 694 & $(10)^{* * *}$ & -4 & $(1)^{* * *}$ & 44 & (1) *** \\
\hline Ratnapura & -7 & (13) & 549 & $(10)^{* * *}$ & -1 & $(0.6)^{*}$ & 32 & (1) *** \\
\hline Kegalle & 5 & (15) & 647 & $(12)^{* * *}$ & -0.4 & (1) & 38 & (1) $)^{* * *}$ \\
\hline Constant & 1529 & $(643)^{* *}$ & 2103 & $(1144)^{*}$ & 609 & $(540)$ & 1912 & $(1075)^{*}$ \\
\hline R2 & 0.52 & & 0.29 & & 0.52 & & 0.29 & \\
\hline Observations & 84393 & & 84393 & & 84393 & & 84393 & \\
\hline
\end{tabular}

Note: Robust standard errors in bracket. ${ }^{* *}, * *, *$, stand for significance at $1 \%, 5 \%$ and $10 \%$ respectively. Model estimations controlled for household covariates i.e. sex, age, years of education, ethnicity of the household head, and household size. The models also controlled for district fixed effects, year fixed effects, and district year fixed effects, district time trend. 


\section{Appendix Table 3-14: Impact of tsunami on household Income and Consumption}

\section{by Districts}

\begin{tabular}{lllll}
\hline Variables & $\begin{array}{l}\text { Income } \\
\text { Coef. }\end{array}$ & SE & $\begin{array}{l}\text { Consumption } \\
\text { Coef. }\end{array}$ & SE \\
\hline Colombo_2006 & 16320 & $(1111)^{* * *}$ & 1184 & $(504)^{* * *}$ \\
Colombo_2009 & 14015 & $(823)^{* * *}$ & 215 & $(324)$ \\
Colombo_2012 & 30901 & $(1630)^{* * *}$ & 5059 & $(526)^{* * *}$ \\
Gampaha2006 & 7300 & $(1112)^{* * *}$ & -435 & $(486)^{*}$ \\
Gampaha_2009 & 4729 & $(822)^{* * *}$ & -595 & $(276)^{* * *}$ \\
Gampaha2012 & 15289 & $(1628)^{* * *}$ & 2354 & $(526)^{* * *}$ \\
Kalutara_2006 & 3596 & $(1117)^{* * *}$ & -286 & $(449)^{* * *}$ \\
Kalutara_2009 & 3217 & $(825)^{* * *}$ & -1420 & $(272)^{* * *}$ \\
Kalutara_2012 & 11810 & $(1623)^{* * *}$ & 1616 & $(542)^{* * *}$ \\
Galle_2006 & 1915 & $(1116)^{* *}$ & 2949 & $(436)^{* * *}$ \\
Galle_2009 & 924 & $(804)$ & 402 & $(251)^{* * *}$ \\
Galle_2012 & 5497 & $(1625)^{* * *}$ & 137 & $(536)$ \\
Matara_2006 & 3533 & $(1118)^{* * *}$ & 2895 & $(430)^{* * *}$ \\
Matara_2009 & 3605 & $(824)^{* * *}$ & 975 & $(242)^{* * *}$ \\
Matara_2012 & 8909 & $(1629)^{* * *}$ & 1133 & $(530)^{* *}$ \\
Hambantota_2006 & 1228 & $(1120)$ & 5145 & $(425)^{* * *}$ \\
Hambantota_2009 & 2035 & $(826)^{* *}$ & 4496 & $(243)^{* * *}$ \\
Hambantota_2012 & 9165 & $(1627)^{* * *}$ & 6988 & $(532)^{* * *}$ \\
Puttlam_2006 & 1086 & $(1116)$ & 1830 & $(426)^{* * *}$ \\
Puttlam_2009 & 2686 & $(824)$ & 1136 & $(230)^{* * *}$ \\
Puttlam_2012 & 1701 & $(1625)$ & 3463 & $(528)^{* * *}$ \\
\hline Constant & 1544 & $(582)^{* * *}$ & 2185 & $(1138)^{*}$ \\
R2 & 0.53 & & 0.29 & \\
\hline
\end{tabular}

Note: Robust standard errors in bracket. ***,**, *, stand for significance at $1 \%, 5 \%$ and $10 \%$ respectively. Model estimations controlled for household covariates i.e. sex, age, years of education, ethnicity of the household head, and household size. The models also controlled for district fixed effects, year fixed effects, and district linear time trend. 


\section{Appendix Table 3-15: Impact of tsunami on household Income by Districts (Diff- in-Diff of each affected district separately with control districts)}

\begin{tabular}{|c|c|c|c|c|c|c|c|}
\hline $\begin{array}{l}\text { Districts } \\
\text { Independent } \\
\text { Variables }\end{array}$ & Colombo & Gampaha & Kalutara & Galle & Matara & Hambantota & Puttlam \\
\hline year_2002 & $\begin{array}{c}-967 \\
(486)^{* *}\end{array}$ & $\begin{array}{c}-67 \\
(398)\end{array}$ & $\begin{array}{l}-315 \\
(241)\end{array}$ & $\begin{array}{l}-293 \\
(253)\end{array}$ & $\begin{array}{c}-524 \\
(208)^{* *}\end{array}$ & $\begin{array}{c}-443 \\
(203)^{* *}\end{array}$ & $\begin{array}{c}-656 \\
(282)^{* * *}\end{array}$ \\
\hline year_2006 & $\begin{array}{c}-450 \\
(1269)\end{array}$ & $\begin{array}{c}34 \\
(1280)\end{array}$ & $\begin{array}{c}-94 \\
(1270)\end{array}$ & $\begin{array}{c}-84 \\
(1272)\end{array}$ & $\begin{array}{c}-202 \\
(1265)\end{array}$ & $\begin{array}{c}-160 \\
(1267)\end{array}$ & $\begin{array}{c}-274 \\
(1264)\end{array}$ \\
\hline year_2009 & $\begin{array}{l}-1017 \\
(876)\end{array}$ & $\begin{array}{c}-533 \\
(889)\end{array}$ & $\begin{array}{l}-661 \\
(869)\end{array}$ & $\begin{array}{l}-650 \\
(872)\end{array}$ & $\begin{array}{l}-769 \\
(862)\end{array}$ & $\begin{array}{l}-726 \\
(865)\end{array}$ & $\begin{array}{c}-841 \\
(862)\end{array}$ \\
\hline year_2012 & $\begin{array}{c}959 \\
(1832)\end{array}$ & $\begin{array}{c}1432 \\
(1841)\end{array}$ & $\begin{array}{c}1307 \\
(1829)\end{array}$ & $\begin{array}{c}1329 \\
(1835)\end{array}$ & $\begin{array}{c}1207 . \\
(1831)\end{array}$ & $\begin{array}{c}1250 \\
(1834)\end{array}$ & $\begin{array}{c}1134 \\
(1831)\end{array}$ \\
\hline Treatment*2006 & $\begin{array}{c}13576 \\
(1188)^{* * *}\end{array}$ & $\begin{array}{c}9744 \\
(1197)^{* * *}\end{array}$ & $\begin{array}{c}5121 \\
(1213)^{* * *}\end{array}$ & $\begin{array}{c}3524 \\
(1207)^{* * * *}\end{array}$ & $\begin{array}{c}2785 \\
(1206)^{* *}\end{array}$ & $\begin{array}{c}1533 \\
(1216)\end{array}$ & $\begin{array}{l}-1350 \\
(1202)\end{array}$ \\
\hline Treatment*2009 & $\begin{array}{c}10177 \\
(801)^{* * *}\end{array}$ & $\begin{array}{c}8148 \\
(808)^{* * *}\end{array}$ & $\begin{array}{c}5396 \\
(823)^{* * *}\end{array}$ & $\begin{array}{c}3216 \\
(816)^{* * *}\end{array}$ & $\begin{array}{c}2564 \\
(815)^{* * *}\end{array}$ & $\begin{array}{c}2486 \\
(824)^{* * *}\end{array}$ & $\begin{array}{l}-759 \\
(818)\end{array}$ \\
\hline Treatment*2012 & $\begin{array}{c}26029 \\
(1771)^{* * *}\end{array}$ & $\begin{array}{c}19714 \\
(1782)^{* * *}\end{array}$ & $\begin{array}{c}14663 \\
(1772)^{* * *}\end{array}$ & $\begin{array}{c}8526 \\
(1767)^{* * *}\end{array}$ & $\begin{array}{c}7621 \\
(1770)^{* * *}\end{array}$ & $\begin{array}{c}9818 \\
(1770)^{* * *}\end{array}$ & $\begin{array}{l}-2705 \\
(1769)\end{array}$ \\
\hline constant & $\begin{array}{c}-962 \\
(1192)\end{array}$ & $\begin{array}{c}-399 \\
(1260)\end{array}$ & $\begin{array}{c}-426 \\
(1892)\end{array}$ & $\begin{array}{l}-1759 \\
(1479)\end{array}$ & $\begin{array}{l}-1551 \\
(1464)\end{array}$ & $\begin{array}{l}-1584 \\
(1341)\end{array}$ & $\begin{array}{l}-1441 \\
(1468)\end{array}$ \\
\hline R-squared & 0.58 & 0.53 & 0.44 & 0.40 & 0.40 & 0.40 & 0.41 \\
\hline $\begin{array}{l}\text { Number of } \\
\text { observationa }\end{array}$ & 51093 & 48306 & 46751 & 46833 & 45717 & 44372 & 44219 \\
\hline
\end{tabular}

Notes: Robust standard errors in bracket. $* * *, * *$, , stand for significance at $1 \%, 5 \%$ and $10 \%$ respectively. Model estimations controlled for household covariates i.e. sex, age, years of education, ethnicity of the household head, and household size and the district fixed effects. 


\section{Appendix Table 3-16: Impact of tsunami on household consumption by Districts (Diff-in-Diff of each affected district separately with control districts)}

\begin{tabular}{|c|c|c|c|c|c|c|c|}
\hline $\begin{array}{l}\text { Districts } \\
\text { Independent } \\
\text { Variables }\end{array}$ & Colombo & Gampaha & Kalutara & Galle & Matara & Hambantota & Puttlam \\
\hline year_2002 & $\begin{array}{c}495 \\
(145)^{* * *}\end{array}$ & $\begin{array}{c}676 \\
(172)^{* * *}\end{array}$ & $\begin{array}{c}722 \\
(214)^{* * *}\end{array}$ & $\begin{array}{c}461 \\
(177)^{* * *}\end{array}$ & $\begin{array}{c}490 \\
(167)^{* * *}\end{array}$ & $\begin{array}{c}386 \\
(240)\end{array}$ & $\begin{array}{c}495 \\
(167)^{* * *}\end{array}$ \\
\hline year_2006 & $\begin{array}{c}2825 \\
(453)^{* * *}\end{array}$ & $\begin{array}{c}3000 \\
(427)^{* * *}\end{array}$ & $\begin{array}{c}3020 \\
(436)^{* * *}\end{array}$ & $\begin{array}{c}2890 \\
(444)^{* * *}\end{array}$ & $\begin{array}{c}2907 \\
(440)^{* * *}\end{array}$ & $\begin{array}{c}2856 \\
(455)^{* * *}\end{array}$ & $\begin{array}{c}2909 \\
(441)^{* * *}\end{array}$ \\
\hline year_2009 & $\begin{array}{c}2236 \\
(191)^{* * *}\end{array}$ & $\begin{array}{c}2411 \\
(159)^{* * *}\end{array}$ & $\begin{array}{c}2491 \\
(166)^{* * *}\end{array}$ & $\begin{array}{c}2301 \\
(159)^{* * *}\end{array}$ & $\begin{array}{c}2318 \\
(155)^{* * *}\end{array}$ & $\begin{array}{c}2268 \\
(176)^{* * *}\end{array}$ & $\begin{array}{c}2320 \\
(156)^{* * *}\end{array}$ \\
\hline year_2012 & $\begin{array}{c}11136 \\
(593)^{* * *}\end{array}$ & $\begin{array}{c}11398 \\
(554)^{* * *}\end{array}$ & $\begin{array}{c}11429 \\
(567)^{* * *}\end{array}$ & $\begin{array}{c}11310 \\
(571)^{* * *}\end{array}$ & $\begin{array}{c}11325 \\
(567)^{* * *}\end{array}$ & $\begin{array}{c}11283 \\
(578)^{* * *}\end{array}$ & $\begin{array}{c}11329 \\
(570)^{* * *}\end{array}$ \\
\hline Treatment*2006 & $\begin{array}{c}1272 \\
(595)^{* *}\end{array}$ & $\begin{array}{c}193 \\
(431)\end{array}$ & $\begin{array}{c}1163 \\
(413)^{* * *}\end{array}$ & $\begin{array}{c}1966 \\
(420)^{* * *}\end{array}$ & $\begin{array}{c}2007 \\
(423)^{* * *}\end{array}$ & $\begin{array}{c}2193 \\
(419)^{* * *}\end{array}$ & $\begin{array}{c}1030 \\
(422)^{* * *}\end{array}$ \\
\hline Treatment*2009 & $\begin{array}{c}304 \\
(376)\end{array}$ & $\begin{array}{c}371 \\
(110)^{* * *}\end{array}$ & $\begin{array}{c}677 \\
(113)^{* * *}\end{array}$ & $\begin{array}{c}-953 \\
(113)^{* * *}\end{array}$ & $\begin{array}{c}-249 \\
(114)^{* *}\end{array}$ & $\begin{array}{c}327 \\
(125)^{* *}\end{array}$ & $\begin{array}{c}64 \\
(113)\end{array}$ \\
\hline Treatment*2012 & $\begin{array}{c}5170 \\
(547)^{* * *}\end{array}$ & $\begin{array}{c}3818 \\
(545)^{* * *}\end{array}$ & $\begin{array}{c}4415 \\
(546)^{* * *}\end{array}$ & $\begin{array}{c}-\mathbf{1 5 6 4} \\
(558)^{* * *}\end{array}$ & $\begin{array}{l}-406 \\
(559)\end{array}$ & $\begin{array}{c}1516 \\
(548)^{* * *}\end{array}$ & $\begin{array}{c}2044 \\
(547)^{* * *}\end{array}$ \\
\hline constant & $\begin{array}{c}1805 \\
(1352)\end{array}$ & $\begin{array}{c}3874 \\
(818)^{* * *}\end{array}$ & $\begin{array}{c}1604 \\
(1336)\end{array}$ & $\begin{array}{c}2797 \\
(1376)^{* *}\end{array}$ & $\begin{array}{c}-93 \\
(1321)\end{array}$ & $\begin{array}{c}2732 \\
(1042)^{* * *}\end{array}$ & $\begin{array}{c}2596 \\
(1250)^{* *}\end{array}$ \\
\hline R-squared & 0.31 & 0.27 & 0.26 & 0.24 & 0.24 & 0.25 & 0.25 \\
\hline $\begin{array}{l}\text { Number of } \\
\text { observations }\end{array}$ & 51039 & 48306 & 46751 & 46833 & 45717 & 44372 & 44219 \\
\hline
\end{tabular}

Notes: Robust standard errors in bracket. ***, **, *, stand for significance at 1\%, 5\% and 10\% respectively.

Model estimations controlled for household covariates i.e. sex, age, years of education, ethnicity of the household head, and household size and the district fixed effects. 


\section{Appendix Table 3-17: Impact on Income components based on the model without}

\section{linear trends (model IV of the table 2 in the manuscript)}

\begin{tabular}{|c|c|c|c|c|c|c|c|}
\hline $\begin{array}{l}\text { Independent } \\
\text { Variables }\end{array}$ & $\begin{array}{l}\text { Paid } \\
\text { income }\end{array}$ & $\begin{array}{l}\text { Agricultural } \\
\text { Income }\end{array}$ & $\begin{array}{c}\text { Non- } \\
\text { agricultural } \\
\text { Income }\end{array}$ & Remittance & Transfers & Dividends & $\begin{array}{c}\text { Rents and } \\
\text { other income }\end{array}$ \\
\hline Treatment*2006 & $\begin{array}{c}1775 \\
(1100)\end{array}$ & $\begin{array}{c}231 \\
(286)\end{array}$ & $\begin{array}{c}4554 \\
(1776)^{* * *}\end{array}$ & $\begin{array}{c}95 \\
(110)\end{array}$ & $\begin{array}{c}173 \\
(55)^{* * *}\end{array}$ & $\begin{array}{c}12 \\
(23)\end{array}$ & $\begin{array}{c}175 \\
(143)\end{array}$ \\
\hline $\begin{array}{l}\text { Wildbootsrap CI } \\
\text { P value }\end{array}$ & $\begin{array}{c}{[-721.6,} \\
4499] \\
(0.2)\end{array}$ & $\begin{array}{c}{[-411.9} \\
1023] \\
(0.54)\end{array}$ & $\begin{array}{c}{[-606,8758]} \\
(0.09)\end{array}$ & $\begin{array}{c}{[-182.3,321]} \\
(0.42)\end{array}$ & $\begin{array}{c}{[34,} \\
304.8] \\
(0.02)\end{array}$ & $\begin{array}{c}{[-47.88} \\
70.53] \\
(0.68)\end{array}$ & $\begin{array}{c}{[-133.7,498.5]} \\
(0.25)\end{array}$ \\
\hline Treatment*2009 & $\begin{array}{c}935 \\
(766)\end{array}$ & $\begin{array}{c}325 \\
(220)\end{array}$ & $\begin{array}{c}3915 \\
(1476)^{* * *}\end{array}$ & $\begin{array}{l}138 \\
(92)\end{array}$ & $\begin{array}{c}64 \\
(53)\end{array}$ & $\begin{array}{c}33 \\
(15)^{* *}\end{array}$ & $\begin{array}{c}424 \\
(179)^{* *}\end{array}$ \\
\hline $\begin{array}{l}\text { Wildbootsrap CI } \\
\text { P value }\end{array}$ & $\begin{array}{c}{[-510.3} \\
2780] \\
(0.33)\end{array}$ & $\begin{array}{c}{[-83.49} \\
924.1] \\
(0.20)\end{array}$ & $\begin{array}{c}{[-138.9} \\
7201] \\
(0.06)\end{array}$ & $\begin{array}{c}{[-80.93,} \\
327.8] \\
(0.17)\end{array}$ & $\begin{array}{c}{[-48.31} \\
191.5] \\
(0.27)\end{array}$ & $\begin{array}{l}{[-4.89} \\
72.24] \\
(0.10)\end{array}$ & $\begin{array}{c}{[39.67,857.5]} \\
(0.03)\end{array}$ \\
\hline Treatment*2012 & $\begin{array}{c}5670 \\
(1852)^{* * *}\end{array}$ & $\begin{array}{c}744 \\
(335)^{* *}\end{array}$ & $\begin{array}{c}6329 \\
(2206)^{* *}\end{array}$ & $\begin{array}{c}943 \\
(253)^{* * *}\end{array}$ & $\begin{array}{c}843 \\
(175)^{* * *}\end{array}$ & $\begin{array}{c}120 \\
(42)^{* * *}\end{array}$ & $\begin{array}{c}426 \\
(118)^{* * *}\end{array}$ \\
\hline $\begin{array}{l}\text { Wildbootsrap CI } \\
\text { P value }\end{array}$ & $\begin{array}{l}{[1353,} \\
9661] \\
(0.02)\end{array}$ & $\begin{array}{l}{[-142.3} \\
1572] \\
\quad(0.13)\end{array}$ & $\begin{array}{c}{[-34.63} \\
11476] \\
(0.05)\end{array}$ & $\begin{array}{c}{[373,1491]} \\
(0.01)\end{array}$ & $\begin{array}{c}{[407.5,} \\
1257] \\
(0.003)\end{array}$ & $\begin{array}{l}{[22.94,} \\
241.9] \\
(0.01)\end{array}$ & $\begin{array}{c}{[135.6,696.9]} \\
(0.01)\end{array}$ \\
\hline constant & $\begin{array}{l}-1121 \\
(880)\end{array}$ & $\begin{array}{c}-43 \\
(203)\end{array}$ & $\begin{array}{c}1206 \\
(568)^{* * *}\end{array}$ & $\begin{array}{c}-286 \\
(116)^{* * * *}\end{array}$ & $\begin{array}{c}-272 \\
(155)^{*}\end{array}$ & $\begin{array}{l}-23 \\
(20)\end{array}$ & $\begin{array}{c}-69 \\
(130)\end{array}$ \\
\hline R-squared & 0.33 & 0.12 & 0.24 & 0.05 & 0.08 & 0.01 & 0.03 \\
\hline
\end{tabular}

Notes: Robust standard errors in bracket. ***, **, *, stand for significance at 1\%, 5\% and 10\% respectively.

Model estimations controlled for household covariates i.e. sex, age, years of education, ethnicity of the household head, household size and district fixed effects and year fixed effects 
Appendix Table 3-18: Impact on Consumption components based on the model without linear trends (model IV in the table 2 in the manuscript)

\begin{tabular}{lcc}
\hline $\begin{array}{l}\text { Dependent var. } \\
\text { Independent var. }\end{array}$ & Food cons & $\begin{array}{c}\text { Non-food cons. } \\
\text { ii }\end{array}$ \\
\hline Treatment*2006 & -287 & 1531 \\
Wildbootsrap CI & {$[-644.7,72.68]$} & $(631.6,2549]$ \\
P value & $(0.13)$ & $(0.002)$ \\
\hline Treatment*2009 & -530 & 760 \\
& $(121)^{* * *}$ & $(277)^{* * *}$ \\
Wildbootsrap CI & {$[-807.1,-257.3]$} & {$[4.69,1358]$} \\
P value & $(0.001)$ & $(0.05)$ \\
\hline Treatment*2012 & -139 & 2929 \\
& $(248)$ & $\left((921)^{* * *}\right.$ \\
\hline Wildbootsrap CI & {$[-728.9,345.8]$} & {$[107.2,4902]$} \\
P value & $(0.56)$ & $(0.05)$ \\
\hline constant & 2840 & -3297 \\
& $(154)^{* * *}$ & $(1119)$ \\
\hline R-squared & 0.27 & 0.23 \\
\hline
\end{tabular}

Notes: Robust standard errors in bracket. ***, **, *, stand for significance at 1\%, 5\% and 10\% respectively.

Model estimations controlled for household covariates i.e. sex, age, years of education, ethnicity of the household head, household size and district fixed effects and year fixed effects 
Appendix Table 3-19: Impact on non-food Consumption components based on the model without linear trends (model IV in the table 2 in the manuscript)

\begin{tabular}{|c|c|c|c|c|c|c|c|c|}
\hline \multirow{2}{*}{$\begin{array}{l}\text { Dependent var. } \\
\text { Independent } \\
\text { var. }\end{array}$} & Housing & Clothing & $\begin{array}{c}\text { Personal } \\
\text { care }\end{array}$ & $\begin{array}{c}\text { Comm. \& } \\
\text { transp. }\end{array}$ & Education & Health & $\begin{array}{l}\text { HH non- } \\
\text { durables }\end{array}$ & $\begin{array}{l}\text { Non-cons. } \\
\text { Expenditure }\end{array}$ \\
\hline & iii & iv & $\mathbf{v}$ & vi & vii & viii & ix & $\mathbf{x}$ \\
\hline Treatment*2006 & $\begin{array}{c}281 \\
(114)^{* *}\end{array}$ & $\begin{array}{c}18 \\
(23)\end{array}$ & $\begin{array}{c}8 \\
(8)\end{array}$ & $\begin{array}{c}300 \\
(88)^{* * *}\end{array}$ & $\begin{array}{c}61 \\
(22)^{* * *}\end{array}$ & $\begin{array}{c}101 \\
(34)^{* * *}\end{array}$ & $\begin{array}{c}4 \\
(9)\end{array}$ & $\begin{array}{c}735 \\
(211)^{* * *}\end{array}$ \\
\hline $\begin{array}{l}\text { Wildbootsrap CI } \\
\text { P value }\end{array}$ & $\begin{array}{l}{[14.56} \\
552.7] \\
(0.04)\end{array}$ & $\begin{array}{c}{[-32.33} \\
75.27] \\
(0.46)\end{array}$ & $\begin{array}{l}{[-10.4} \\
26.43] \\
((0.38)\end{array}$ & $\begin{array}{l}{[129.5} \\
497.1] \\
(0.00)\end{array}$ & $\begin{array}{l}{[6.659} \\
103.8] \\
(0.03)\end{array}$ & $\begin{array}{c}{[15.94,} \\
175] \\
(0.03)\end{array}$ & $\begin{array}{l}{[-13.7} \\
28.14] \\
0.70)\end{array}$ & $\begin{array}{c}{[250.7,1286]} \\
(0.004)\end{array}$ \\
\hline Treatment*2009 & $\begin{array}{c}280 \\
(163)^{*}\end{array}$ & $\begin{array}{c}-68 \\
(22)^{* * *}\end{array}$ & $\begin{array}{l}-.1 \\
(8)\end{array}$ & $\begin{array}{l}100 \\
(73)\end{array}$ & $\begin{array}{c}125 \\
(40)^{* * *}\end{array}$ & $\begin{array}{c}106 \\
(28)^{* * *}\end{array}$ & $\begin{array}{l}-14 \\
(7)^{*}\end{array}$ & $\begin{array}{c}325 \\
(165)^{* *}\end{array}$ \\
\hline $\begin{array}{l}\text { Wildbootsrap CI } \\
\text { P value }\end{array}$ & $\begin{array}{c}{[-5.241} \\
700] \\
(0.06)\end{array}$ & $\begin{array}{c}{[-121.4,-} \\
15.15] \\
(0.02)\end{array}$ & $\begin{array}{c}{[-19.09} \\
18.74] \\
(0.99)\end{array}$ & $\begin{array}{c}{[-93.88} \\
257.9] \\
(0.23)\end{array}$ & $\begin{array}{l}{[24.07} \\
222.3] \\
(0.01)\end{array}$ & $\begin{array}{l}{[25.07} \\
167.1] \\
(0.01)\end{array}$ & $\begin{array}{c}{[-30.98} \\
3.556] \\
(0.1)\end{array}$ & $\begin{array}{c}{[-26.58} \\
736.5] \\
(0.08)\end{array}$ \\
\hline Treatment*2012 & $\begin{array}{c}1001 \\
(561)^{*}\end{array}$ & $\begin{array}{c}2 \\
(22)\end{array}$ & $\begin{array}{c}47 \\
(27)^{*}\end{array}$ & $\begin{array}{c}385 \\
(245)\end{array}$ & $\begin{array}{c}256 \\
(108)^{* *}\end{array}$ & $\begin{array}{c}239 \\
(57)^{* * *}\end{array}$ & $\begin{array}{l}-12 \\
(9)\end{array}$ & $\begin{array}{c}967 \\
(467)^{* *}\end{array}$ \\
\hline $\begin{array}{l}\text { Wildbootsrap CI } \\
\text { P value }\end{array}$ & $\begin{array}{c}{[-67.18} \\
2448] \\
(0.08)\end{array}$ & $\begin{array}{c}{[-45.42} \\
55.86] \\
(0.93)\end{array}$ & $\begin{array}{c}{[-31.92} \\
106] \\
(0.22)\end{array}$ & $\begin{array}{c}{[-220.8} \\
937.2] \\
(0.22)\end{array}$ & $\begin{array}{l}{[24.95} \\
510.7] \\
(0.03)\end{array}$ & $\begin{array}{l}{[101.4,} \\
362.2] \\
(0.004)\end{array}$ & $\begin{array}{c}{[-32.89} \\
10.02] \\
(0.26)\end{array}$ & $\begin{array}{c}{[-207.5,2040]} \\
(0.10)\end{array}$ \\
\hline constant & $\begin{array}{l}-1134 \\
(605)^{* *}\end{array}$ & $\begin{array}{c}88 \\
(30)^{* * *}\end{array}$ & $\begin{array}{c}-3 \\
(19)\end{array}$ & $\begin{array}{c}-662 \\
(388)\end{array}$ & $\begin{array}{c}-262 \\
(64)^{* * *}\end{array}$ & $\begin{array}{c}-10 \\
(122)\end{array}$ & $\begin{array}{c}40 \\
(11)^{* * *}\end{array}$ & $\begin{array}{c}-1165 \\
(195)^{* * *}\end{array}$ \\
\hline R-squared & 0.29 & 0.16 & 0.26 & 0.12 & 0.06 & 0.03 & 0.12 & 0.07 \\
\hline
\end{tabular}

Notes: Robust standard errors in bracket. ${ }^{* *}, * *, *$, stand for significance at $1 \%, 5 \%$ and $10 \%$ respectively.

Model estimations controlled for household covariates i.e. sex, age, years of education, ethnicity of the household head, household size and district fixed effects and year fixed effects 


\section{Appendix Table 3-20: Placebo test by treating the treatment group pre-tsunami}

year 2002

\begin{tabular}{lll}
\hline Variables & $\begin{array}{l}\text { Income } \\
\text { (District Clustered Robust }\end{array}$ & $\begin{array}{l}\text { Consumption } \\
\text { (District Clustered Robust } \\
\text { S. E.) }\end{array}$ \\
\hline year_2002 & -538 & 467.16 \\
& $(214)^{* *}$ & $(179.78)^{* *}$ \\
year_2006 & -1532 & 2759.05 \\
& $(1319)$ & $(483.28)^{* * *}$ \\
year_2009 & -2518 & 1643.05 \\
& $(1270)^{* *}$ & $(351.43)^{* * *}$ \\
year_2012 & 4260 & 11854.75 \\
& $(1868)^{* *}$ & $(440.55)^{* * *}$ \\
Treatment*Post disaster & 9537 & 1381.83 \\
& $(2591)^{* * *}$ & $(641)^{* *}$ \\
Treatment ${ }^{* *}$ year2002 & 274 & -52 \\
& $(950)$ & $(422)$ \\
Constant & 284 & 2666 \\
& $(1557)$ & $(1205)^{* *}$ \\
\hline R squared & 0.50 & 0.28 \\
\hline
\end{tabular}

Notes: Robust standard errors in bracket. ${ }^{* *}, * *, *$, stand for significance at $1 \%, 5 \%$ and $10 \%$ respectively. Model estimations controlled for household covariates i.e. sex, age, years of education, ethnicity of the household head, and household size and the district fixed effects.

\section{Appendix Table 3-21: Robustness check removing districts those deviate from parallel trend}

\begin{tabular}{lll}
\hline Variables & $\begin{array}{l}\text { Income } \\
\text { (District Clustered Robust }\end{array}$ & $\begin{array}{l}\text { Consumption } \\
\text { (District Clustered Robust } \\
\text { S. E.) }\end{array}$ \\
\hline S. E.) & 1420 \\
& 7063 & $(745)^{*}$ \\
& $(2962)^{* * *}$ & {$[-229.7,3270]$} \\
& {$[465.3,14316]$} & $(0.09)$ \\
Treatment*year2006 & $(0.03)$ & 449 \\
& 5960 & $(500)$ \\
& $(2505)^{* * *}$ & {$[-611.9,1623]$} \\
Treatment*year2012 & {$[992.1,12244]$} & $(0.36)$ \\
& $(0.01)$ & 5091 \\
& 15072 & $(959) * * *$ \\
& $(4883)^{* * *}$ & {$[926.1,5266]$} \\
& {$[4259,26639]$} & $(0.01)$ \\
\hline Constant & $(0.01)$ & 1916 \\
& 4030 & $(1155)$ \\
\hline R squared & $(704)^{* * *}$ & 0.28 \\
\hline
\end{tabular}

Note: Robust standard errors in bracket. ${ }^{* *}, * *, *$, stand for significance at $1 \%, 5 \%$ and $10 \%$ respectively. Model estimations controlled for household covariates i.e. sex, age, years of education, ethnicity of the household head, and household size. The models also controlled for district fixed effects, year fixed effects, and district linear time trend. 


\section{Appendix Figure 3-1: Economic growth rate}

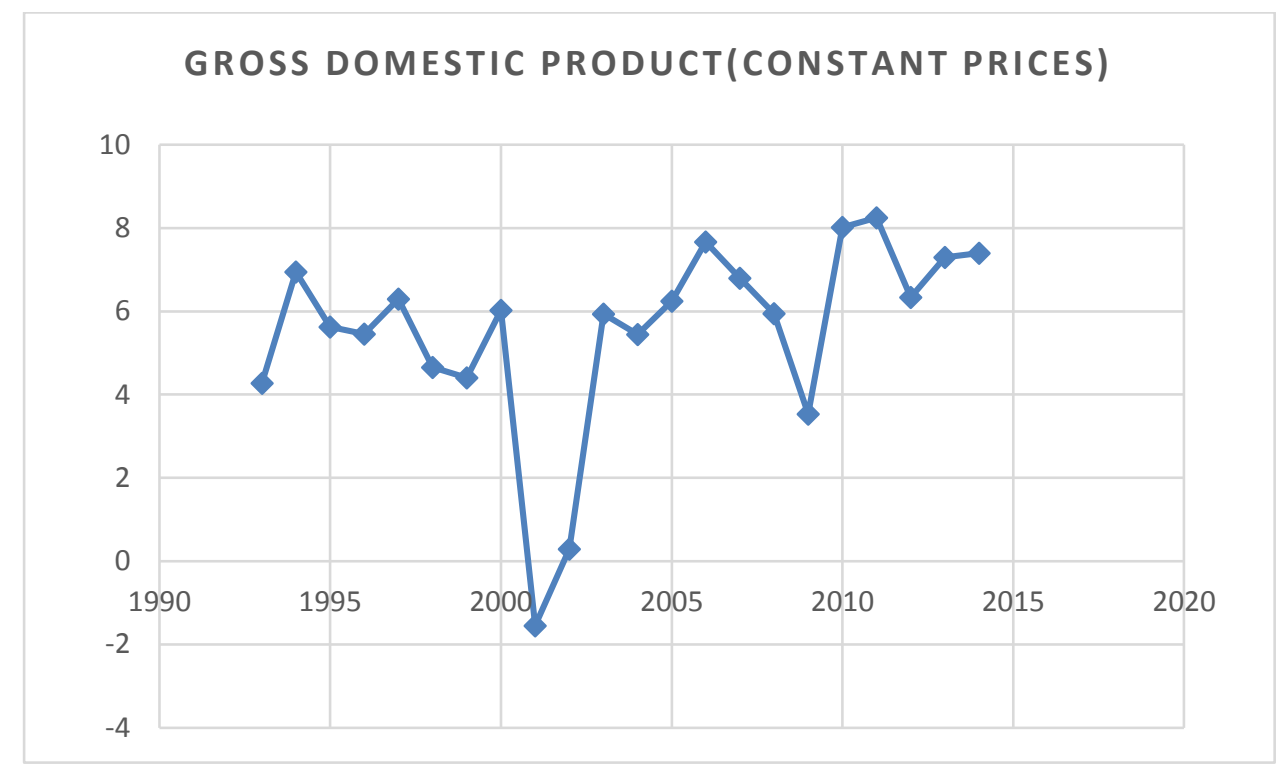

Source: International Monetary Fund, World Economic Outlook Database, April 2015

\section{Appendix Figure 3-2: Tsunami affected Districts in Sri Lanka}

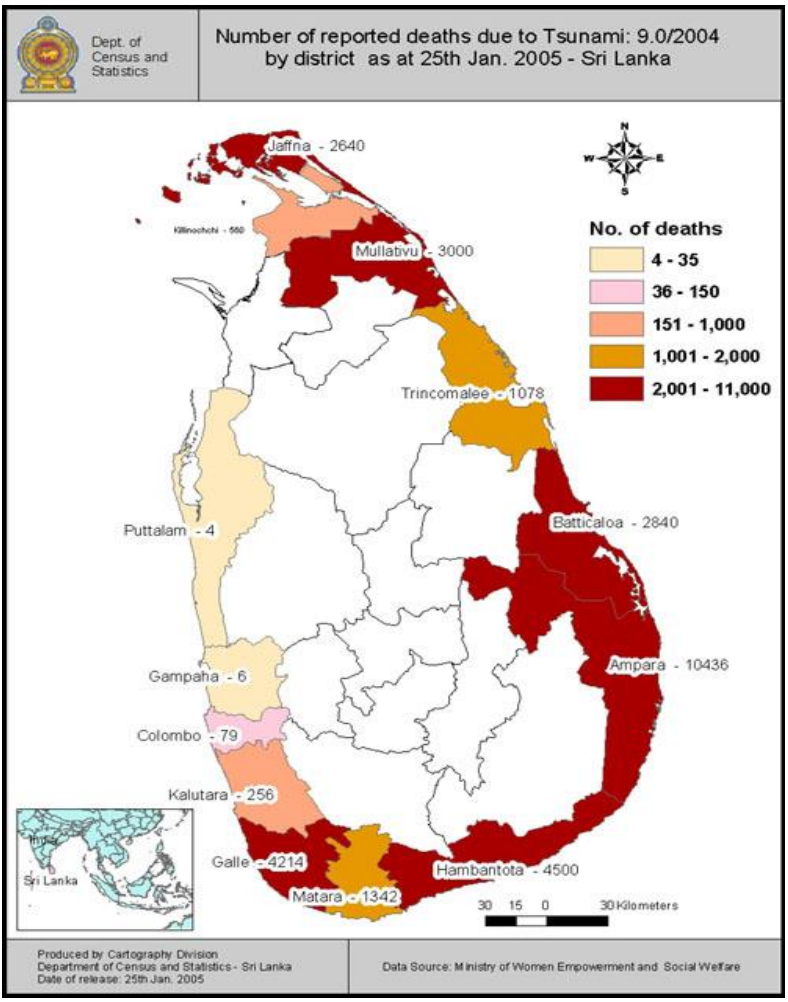

Source: Department of census and statistics (2005)

Appendix Figure 3-3: Tsunami Damage across Districts 


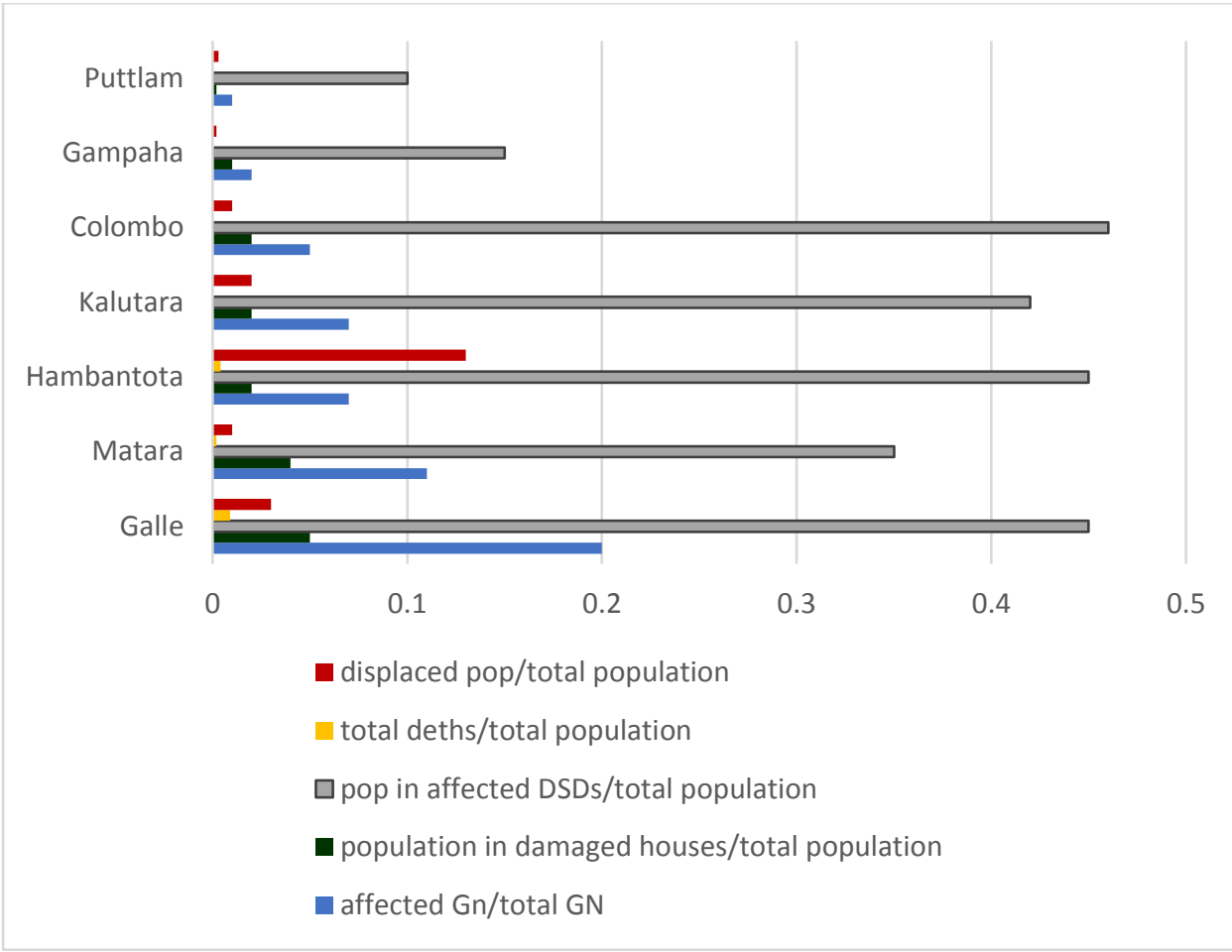

Source: Author calculated using Census and Statics data (2005)

Appendix Figure 3-4: Average household income across districts over the survey period

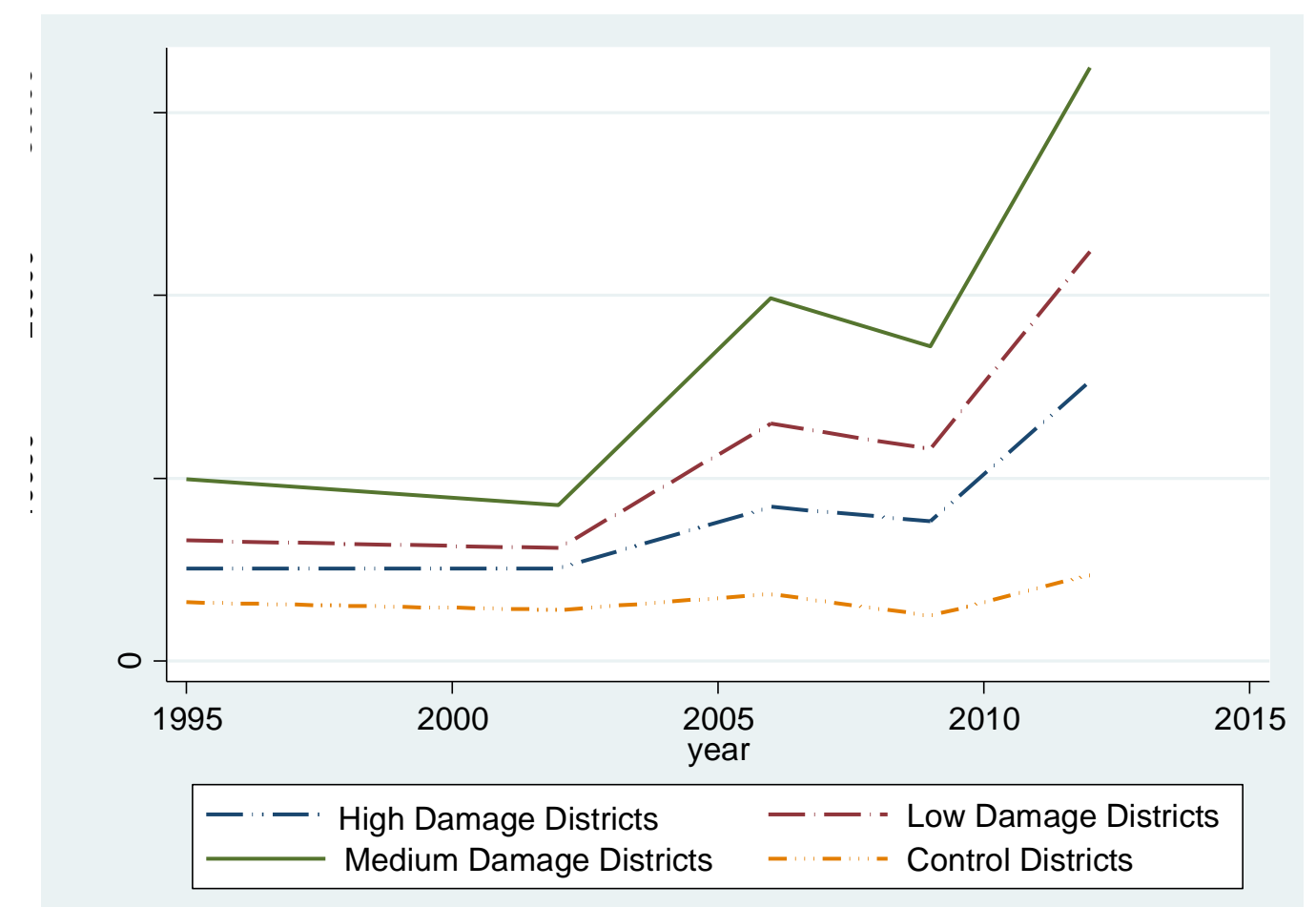


Appendix Figure 3-5: Average household consumption across districts over the survey period

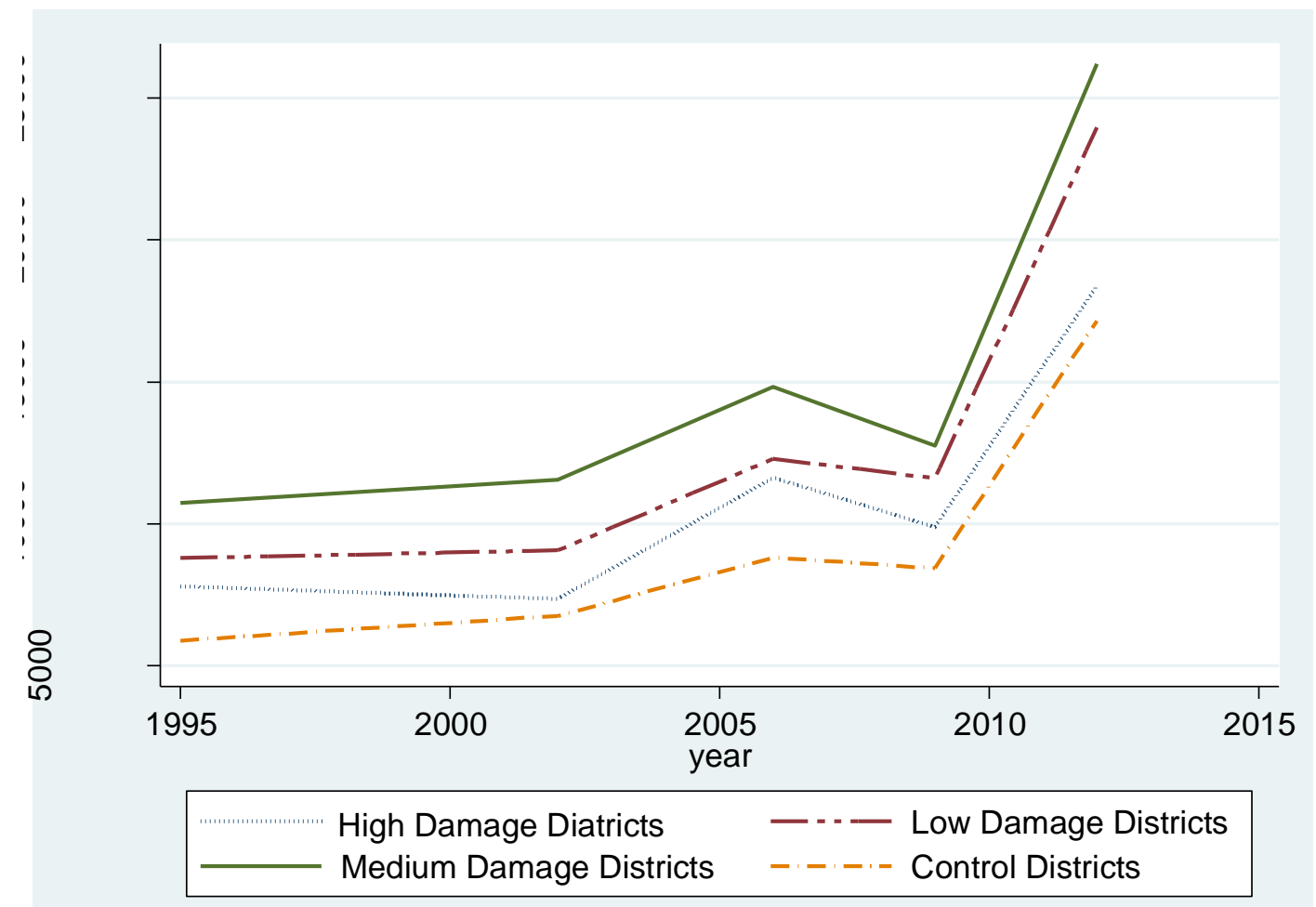

Appendix Figure 3-6: Normalized Income by Districts

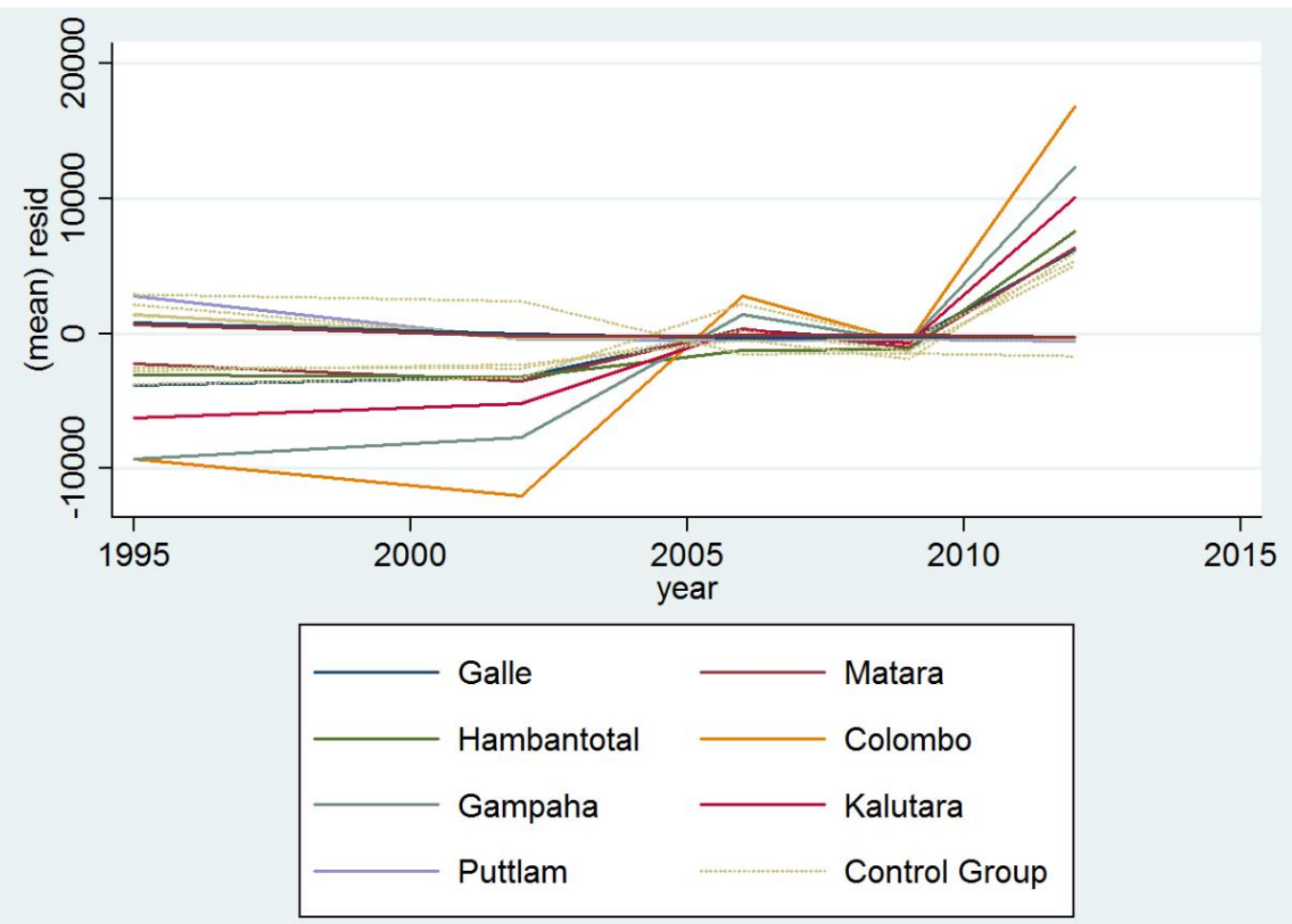




\section{Appendix Figure 3-7: Normalized Consumption by Districts}

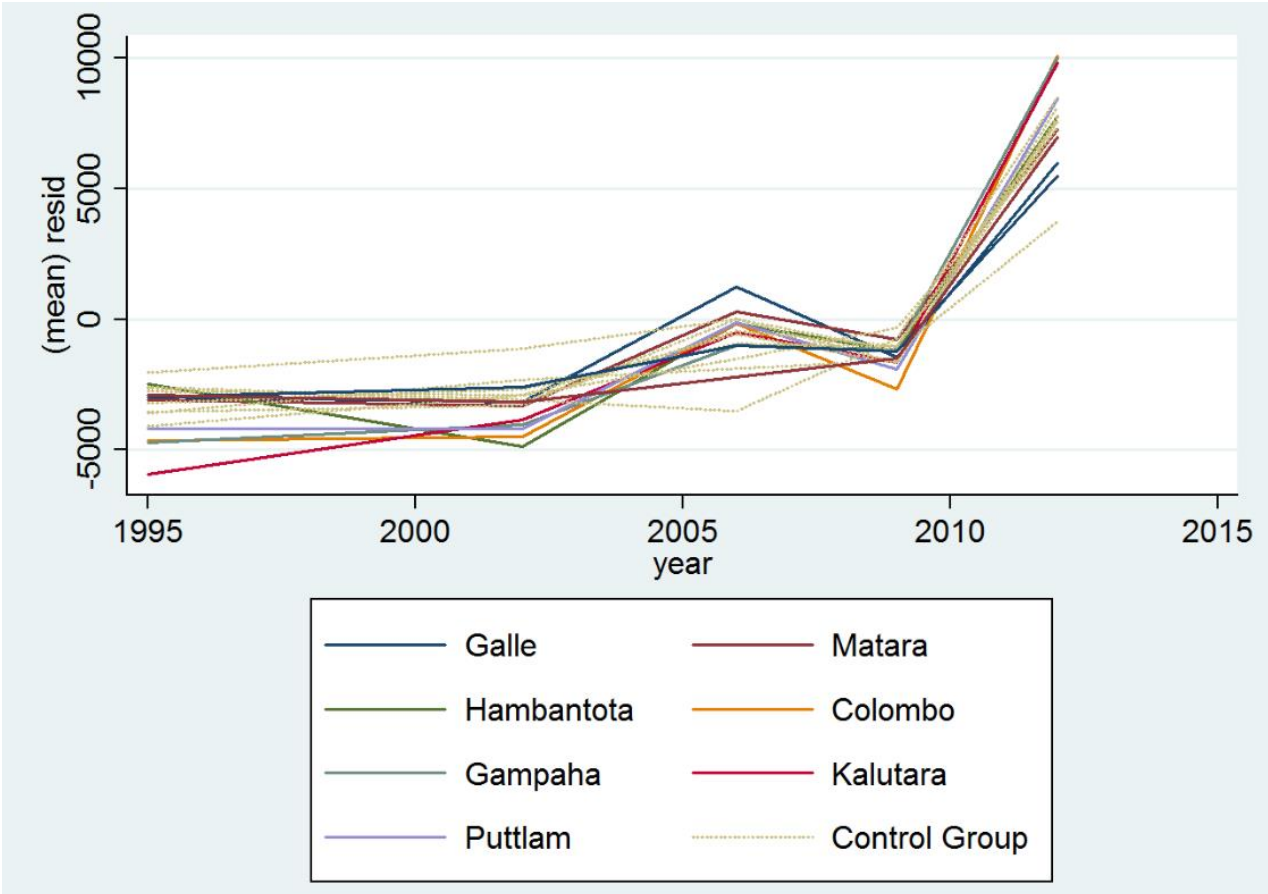




\section{Appendix Figure 3-8: Distribution of residuals}

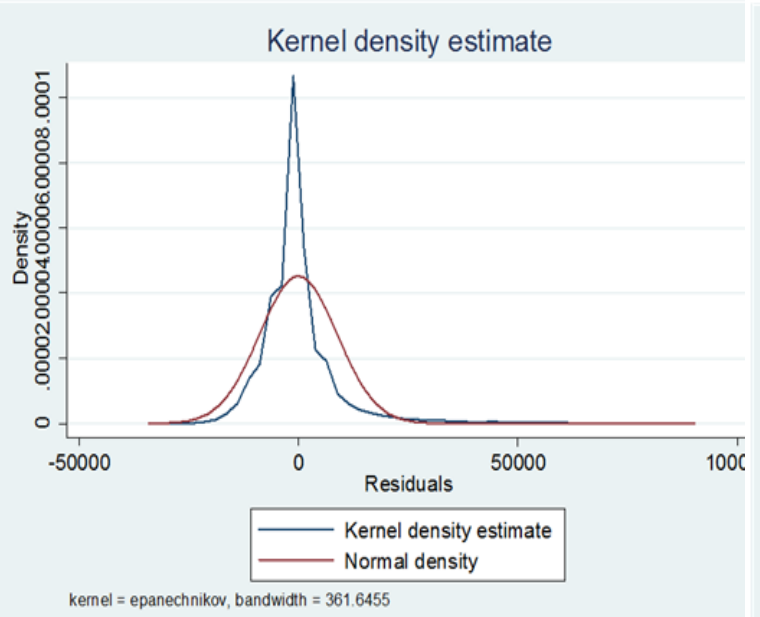

Distribution of Residuals income

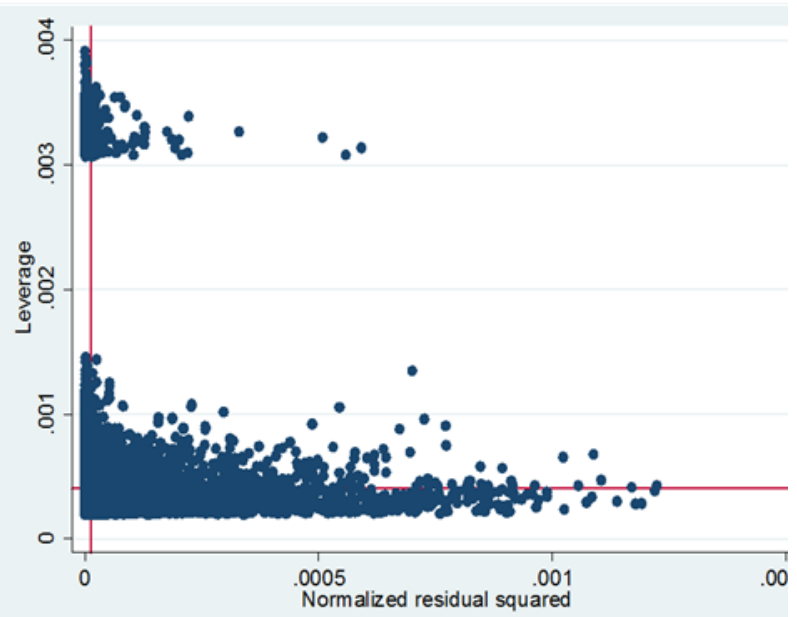

Leverages against squared residuals income

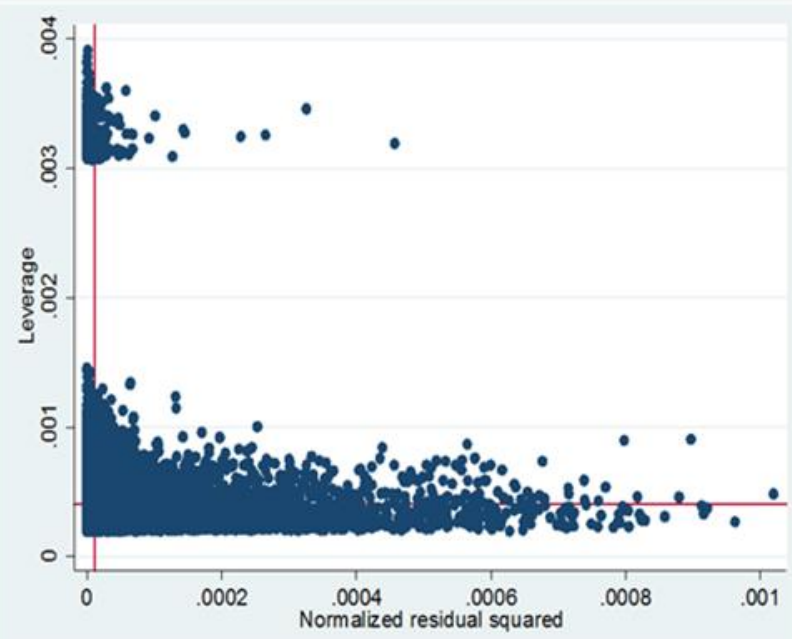

Leverages against squared residuals consumption 


\section{Appendix Figure 3-9: Distribution of Residuals using Log}

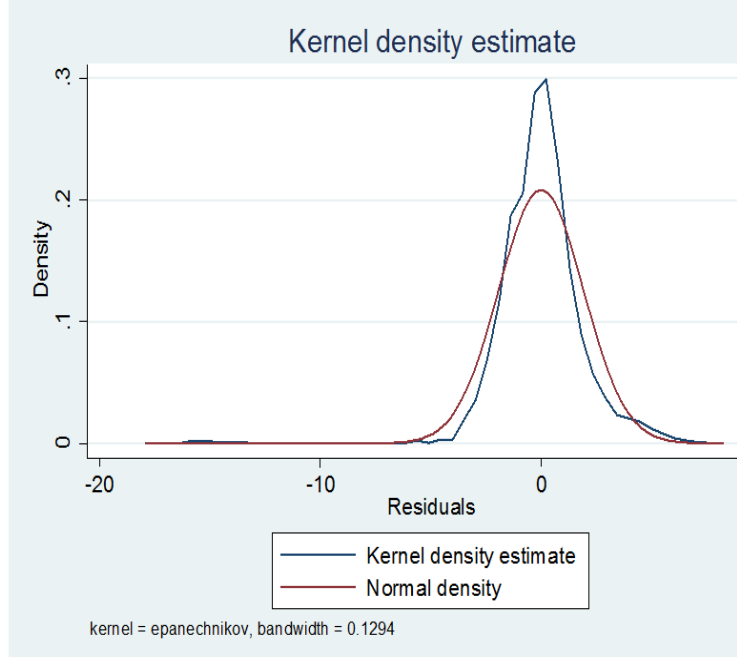

Distribution of Residuals income

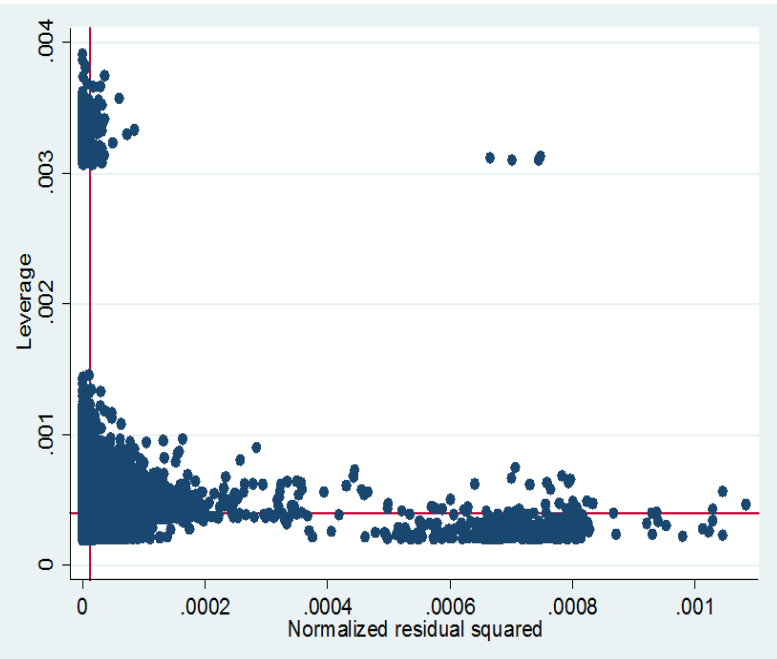

Leverages against squared residuals Income

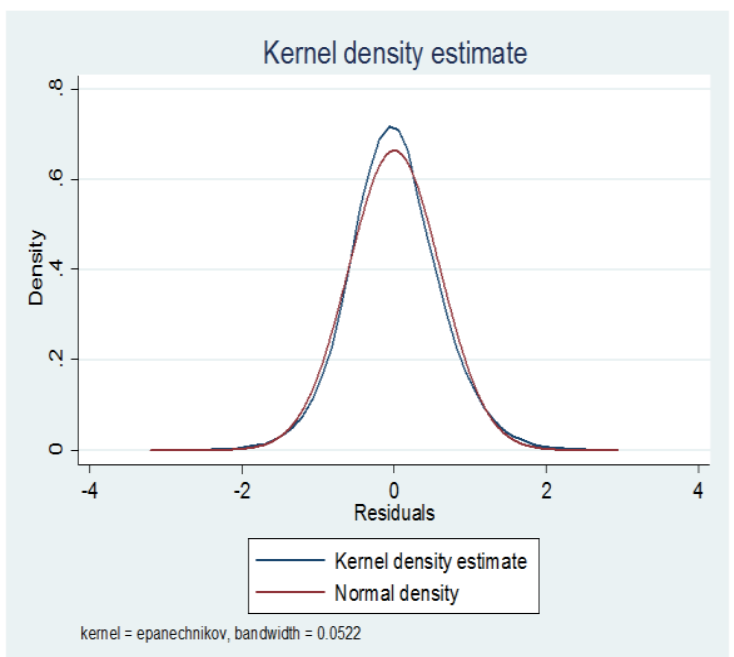

Distribution of Residuals consumption

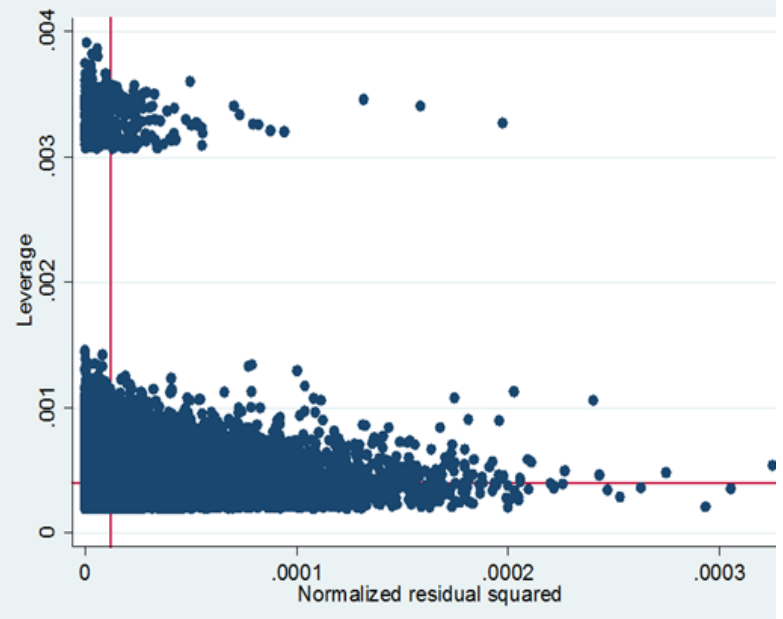

Leverages against squared residuals Consumption 

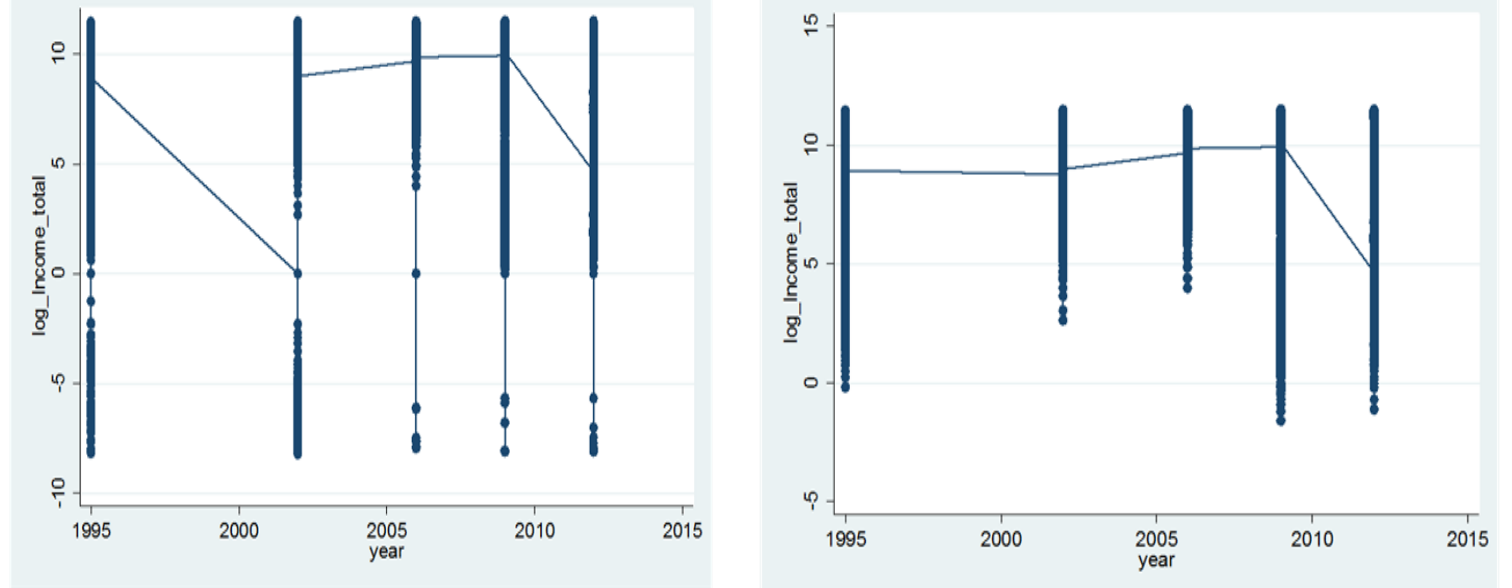

Income

Log of Income
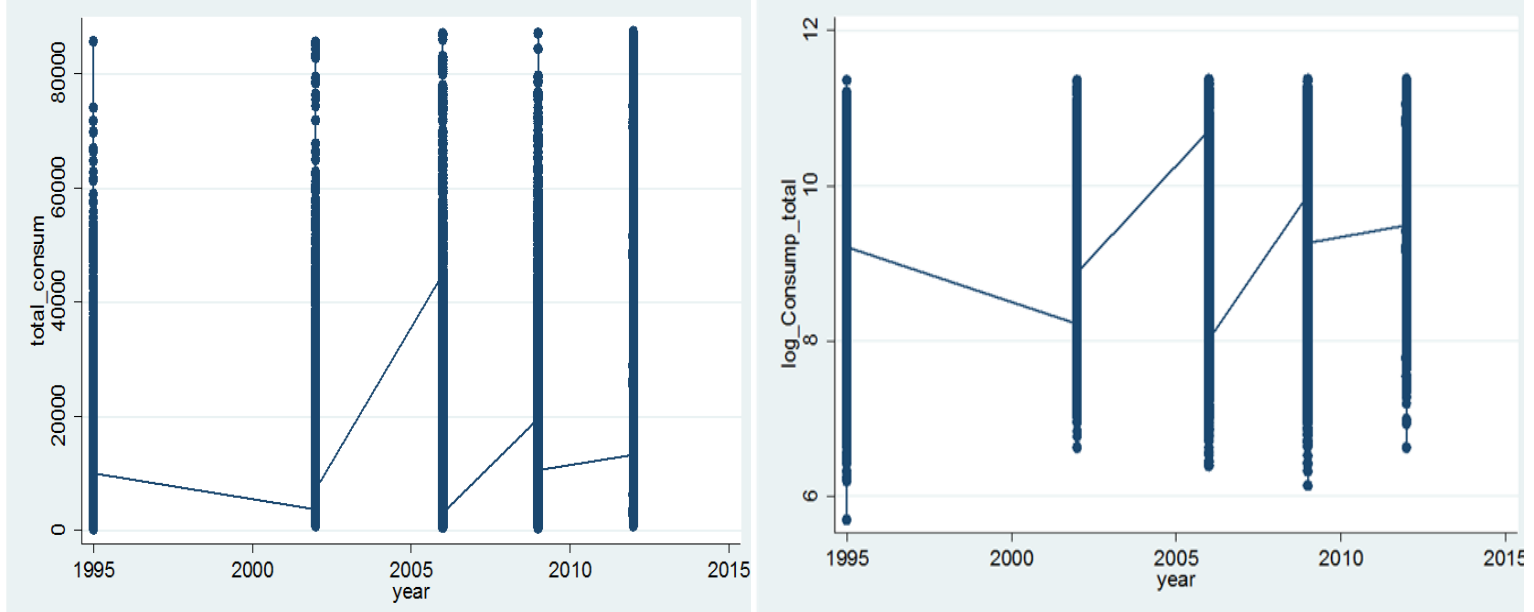

Consumption

Log of Consumption 
Appendix Figure 3-11: Test for

\section{Homoscedasticity}
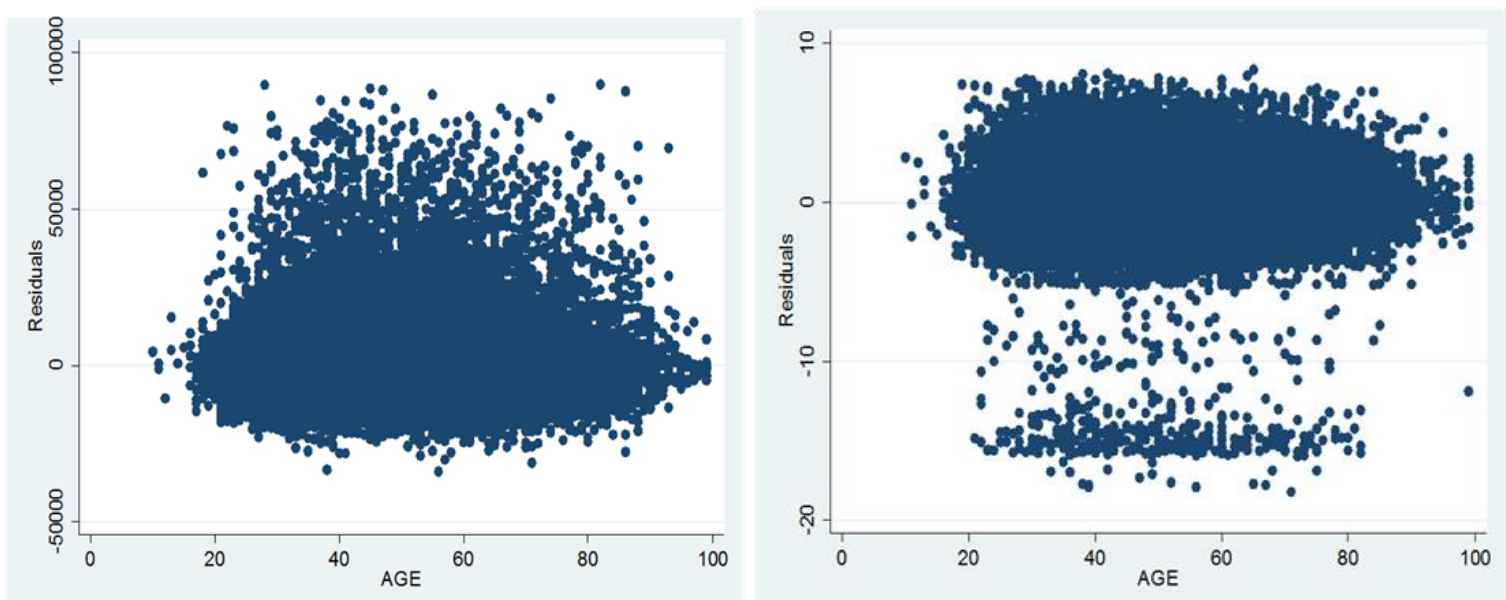

Income

Log of income
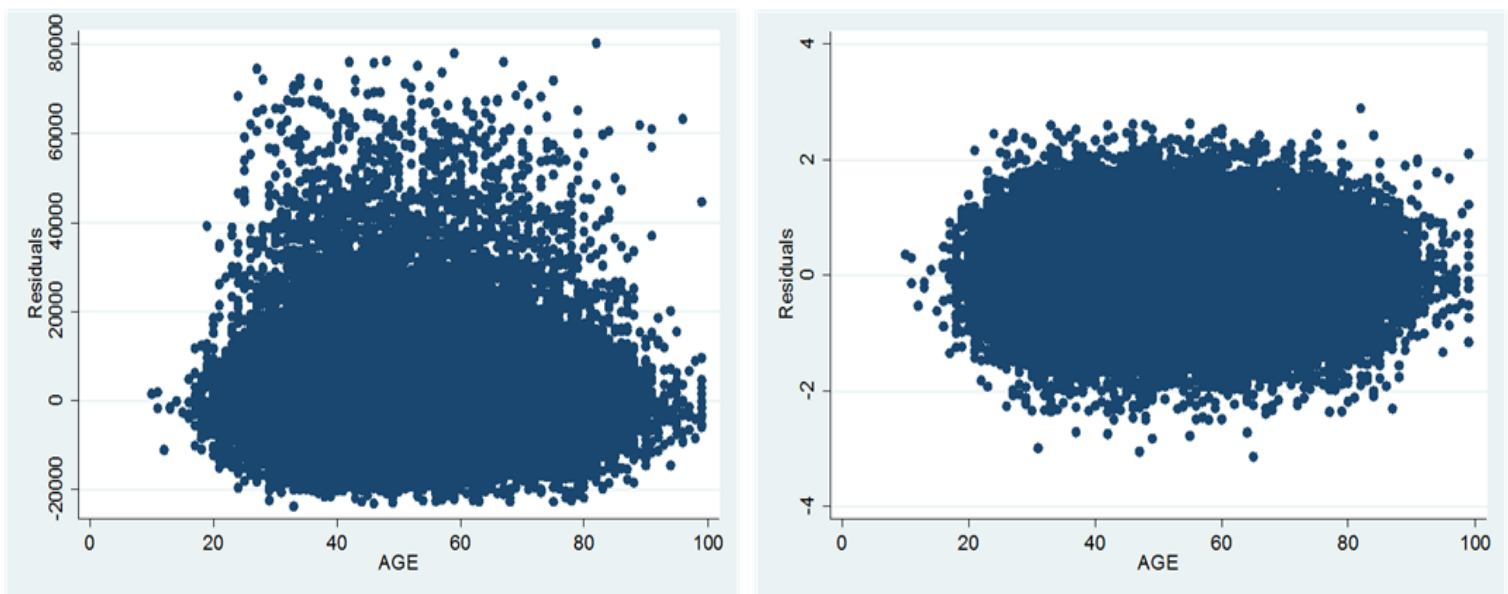

Consumption

Log of consumption 
Appendix Figure 3-12: Scatter plot of outcome variables for each District (i) Consumption

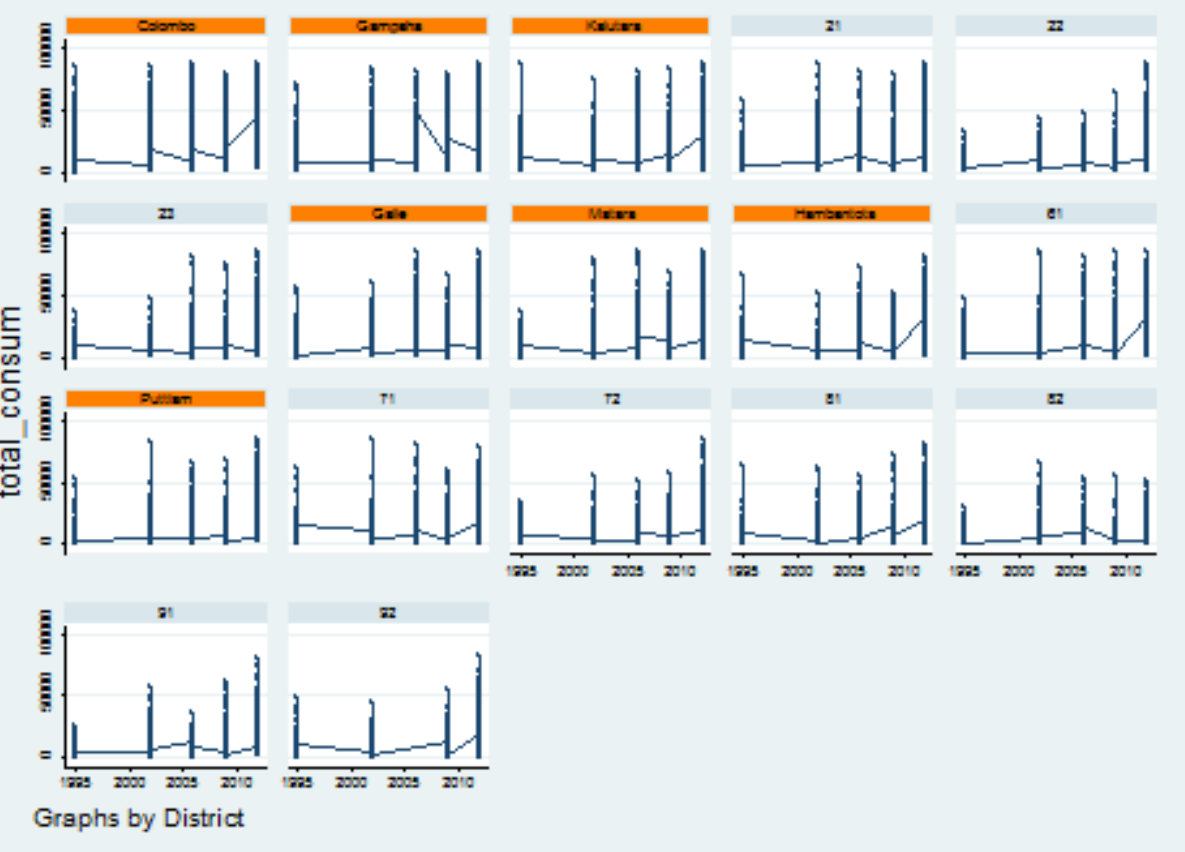

(ii) Income

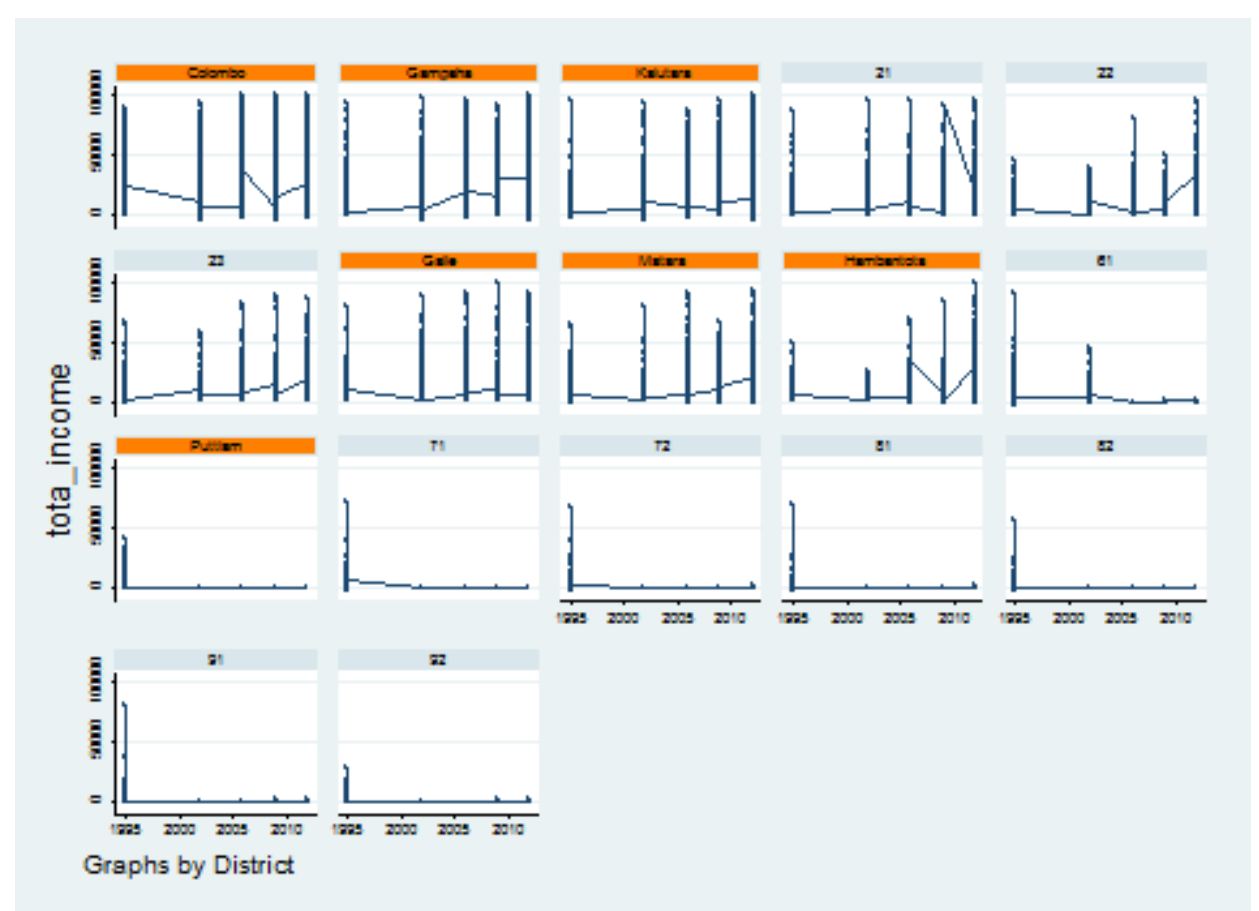


Appendix Figure 3-13: Distribution of income in survey years

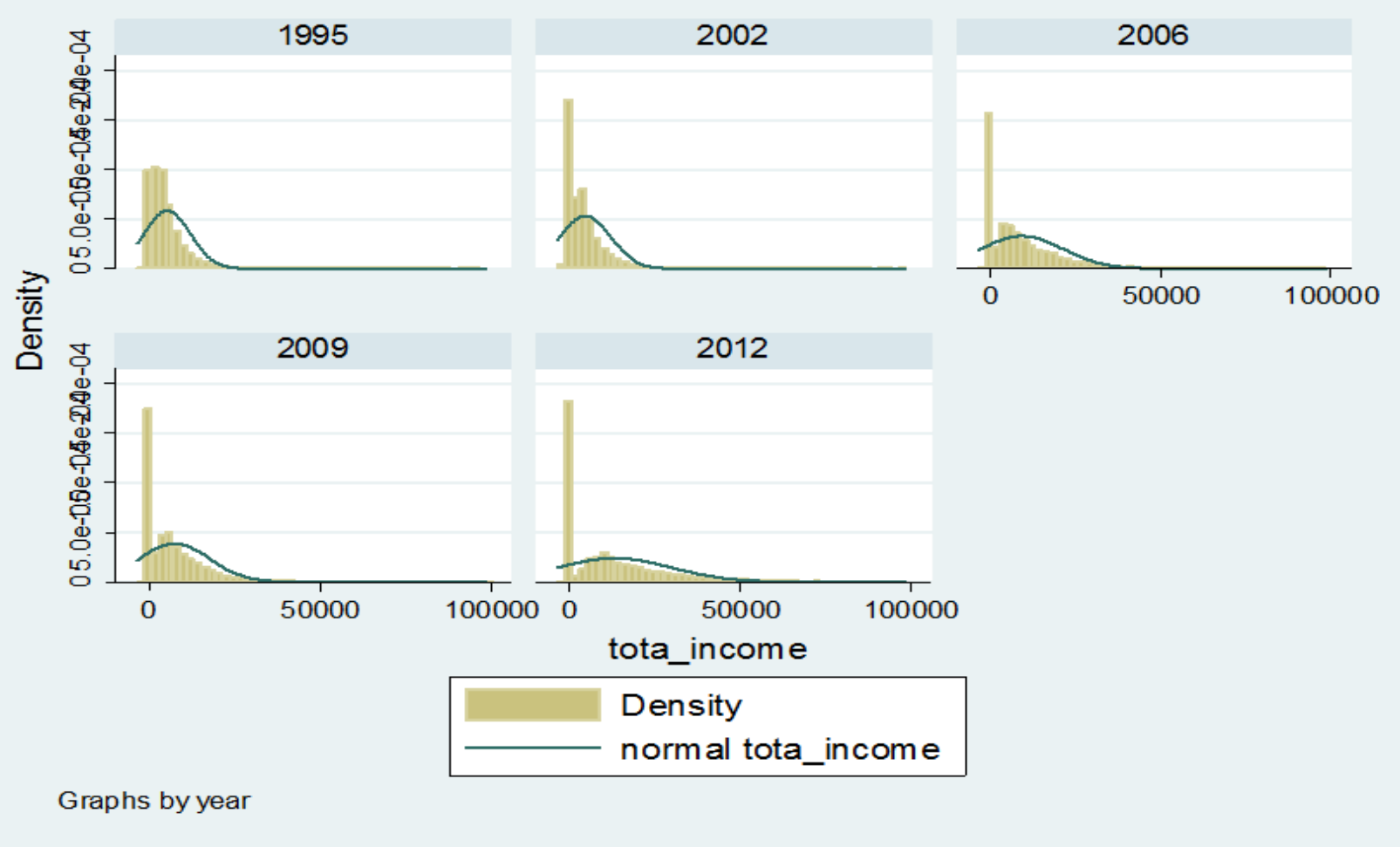

Appendix Figure 3-14: Distribution of consumption in survey years

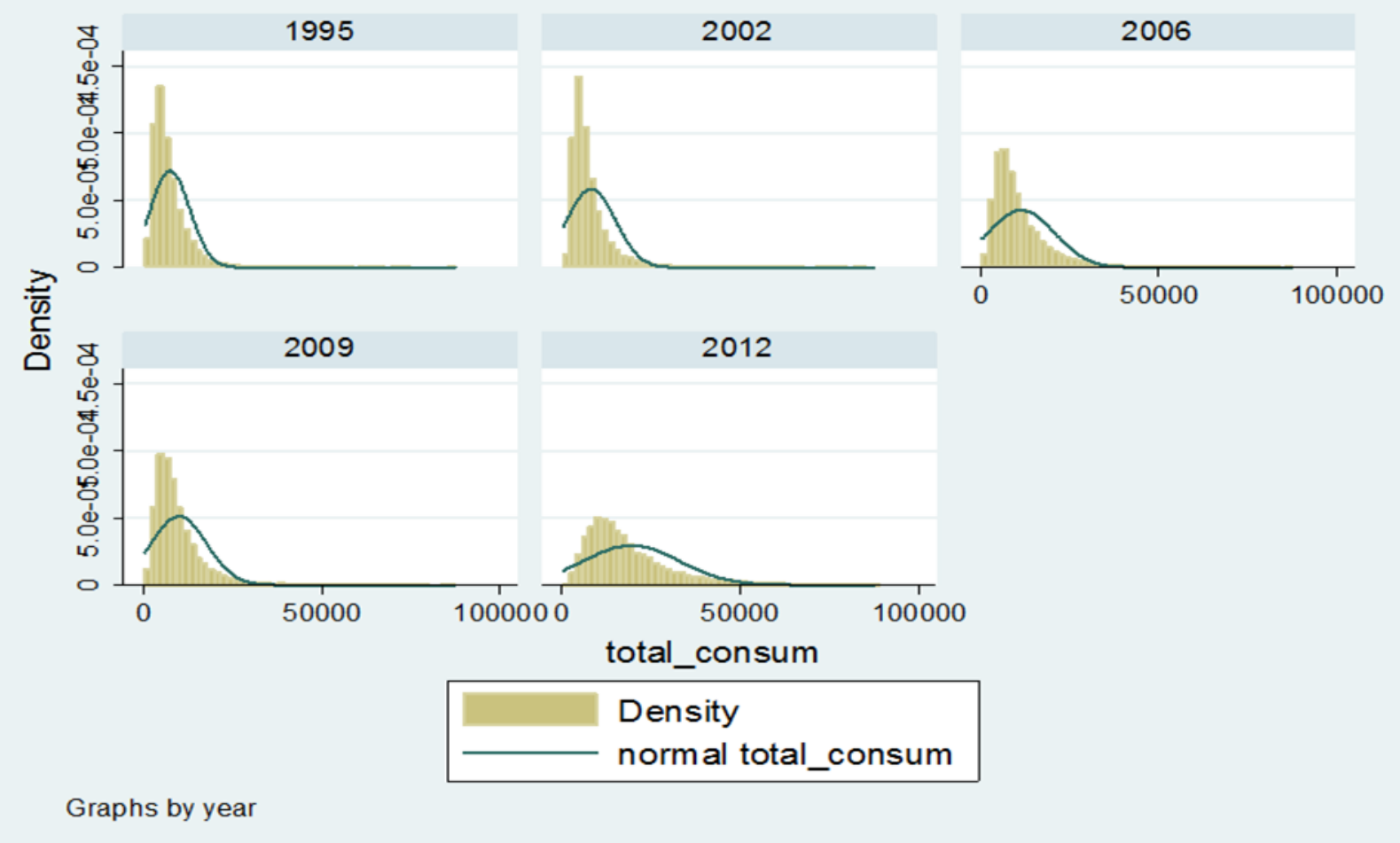




\section{Appendix Figure 3-15: District level net migration}

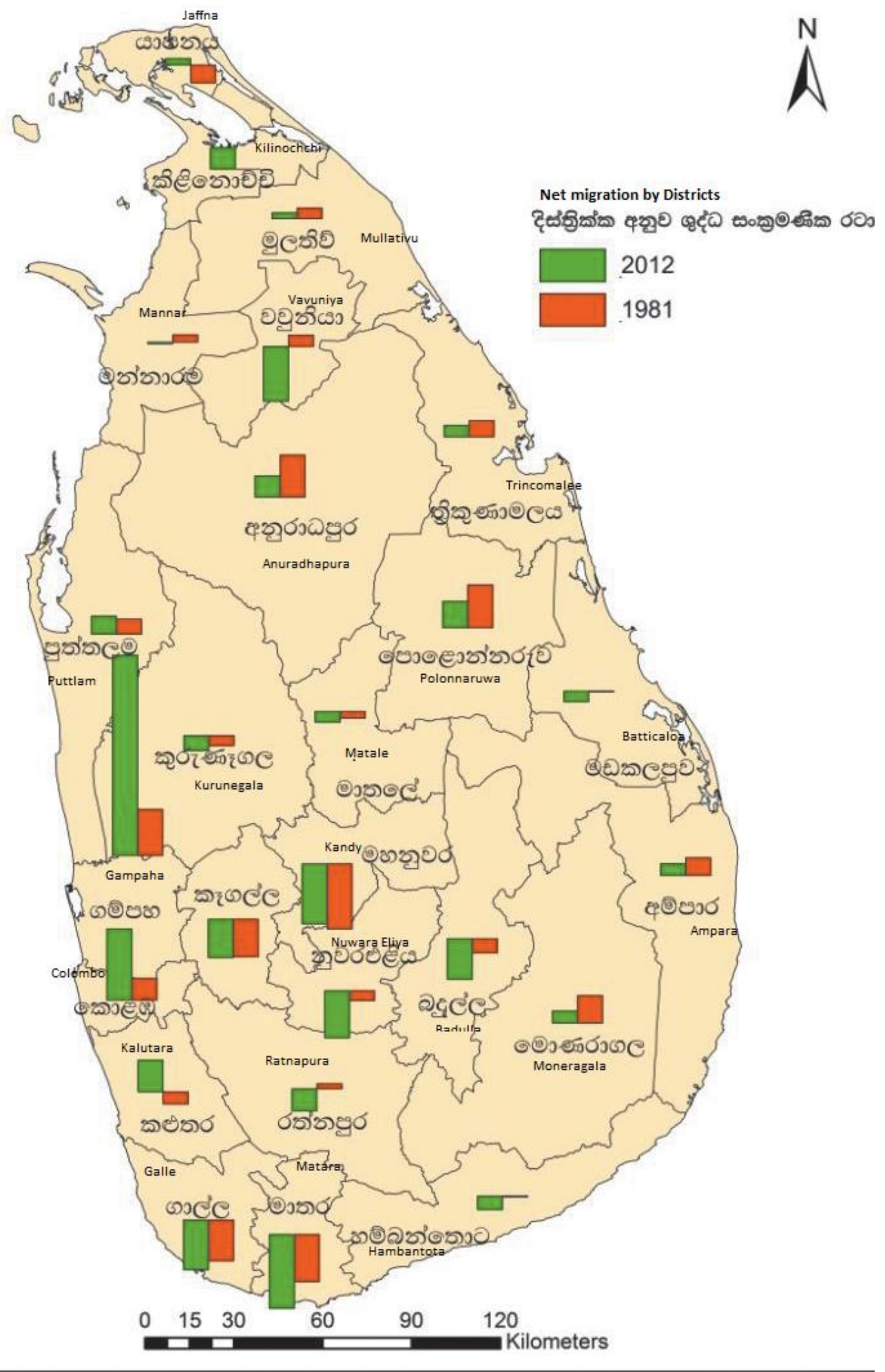

Source: Department of Census and Statistics (2013) 


\title{
Chapter Four
}

\section{Distributional impacts of disaster}

\author{
recovery: Sri Lankan Households a
}

\section{decade after the 2004 Indian Ocean}

\section{tsunami}

\begin{abstract}
This paper investigates the impact of recovery from the 2004 tsunami on income and consumption distribution across households in Sri Lanka, using quantile Diff-in-Diff and Change-in-Change methods, and other inequality measures. The analysis finds that the income of affected households in the entire distribution has recovered, with low-income households increasing their income by a higher proportion compared to the higher income households. The paper also observes that the affected regions appear more income-equal ex-post compared to the unaffected regions. A similar pattern appears for consumption inconsistently across empirical methods. Nonetheless, the study does not find credible evidence for increasing inequality associated with long-lasting recovery from the catastrophic tsunami in Sri Lanka.
\end{abstract}




\subsection{Introduction}

Distributional impacts of disaster recovery is a topic that has received considerable critical attention in policy debate, but not treated in much detail in the empirical literature. This paper examines the causal effect of recovery from the catastrophic tsunami in 2004 on different parts of the income distribution of Sri Lankan households a decade after the event. While standard economic theory suggests a complete recovery in the long term after catastrophic natural disasters (Albala-Bertrand, 1993), the empirical literature finds mixed evidence. A segment of empirical literature provides evidence of the reconstruction process producing higher productivity and higher growth - a recovery that leads to the economy being better off than before (Skidmore and Toya, 2002; Hallegate and Dumas, 2009; Kim, 2010; Jaramillo, 2009). So far, only very few studies have attempted to investigate the recovery impacts on income distribution. Disaster economics research does attempt to determine only the distribution of disaster impacts based on pre-existing social physical and economic vulnerabilities (Buia et al, 2014; Yamamura, 2015; Karim and Noy, 2016). This void in the literature is the key motivating factor of this paper.

Specific to the observation of Sri Lankan households after the 2004 tsunami, De Alwis and Noy, (2016) found evidence for potentially successful long-lasting recovery of households affected by the disaster. It is still uncertain whether the observed average household's recovery is equally across the entire distribution of affected households. In this paper, we aim to examine the Sri Lankan household's recovery in two measures. Firstly, this paper investigates the recovery benefits distribution across affected household groups using methods applied to evaluate distributional impacts in the program evaluation literature. Secondly, we evaluate the impact of recovery on inequality quantitatively using Gini coefficients, generalized entropy measures (GE) and graphically using the Lorenz curve approach. This research uses information from five household income and expenditure survey waves of Sri Lanka (1995, 2002, 2006, 2009, and 2013).

\subsection{Literature}


The theoretical literature identifies complex interactions of factors such as household assets, their ownership, their utilization and return, income generating opportunities available to them and their decisions, the level of their access to public goods, dimensions such as their exclusion, political voice, social capital, and existing institutions and governance structures all determining the level of household income and poverty (Attanasio and Székely, 1999, Carter and Barrett, 2006, Rodriguez -Orregea et al, 2009; Hallegatte et al, 2014). By interfering with one or more of these factors and causal channels, exogenous natural shocks appear to affect the household's level of income and consumption. Disasters can destroy or damage the household's productive assets (physical, natural, financial, public infrastructure etc.) or force households to liquidate their assets to maintain their consumption after the disaster (Kazianga and Udry, 2006; Barrett et al., 2006). With limited ability to share risk, households can fall into poverty traps if disasters cause heavy destruction of household assets (Carter and Barrett, 2006). When disasters are large enough to affect the economic or environmental conditions, the returns to household assets can be impaired, for example by reducing labour or agricultural land productivity (Food and Agriculture organization [FAO], 2015). Catastrophic disasters with extremely high damage to resources can also increase the price of food, energy, or land (Cavallo, Cavallo, and Rigobon, 2014; Haraguchi \& Lall, 2015) hurting mostly the poor.

Empirical literature that investigates disaster recovery reveals that recovery correlates negatively with the extent of property damage to business (Tierney, 1997; Alesch et al. 2001; Chang and Falit-Baiamonte, 2002; Lam et al. 2009). However, businesses with little damage but with highly damaged neighborhoods often find it difficult to recover due to loss of customers (Webb, Tierney and Dahlhamer, 2000; Chang and Baiamonte 2002). The recent modelling approaches (Hallegatt and Vogt-Schilb, 2016) model disaster impacts in the economic aggregates incorporating reconstruction dynamics. The empirical literature finds that delays in infrastructure restoration can be a significant barrier to businesses re-opening (Webb et al. 2000, 2002; Lam et al. 2009) and some types of businesses, sectors, and local economies tend to have greater difficulty to recover from disasters than others (Dahlhamer and Tierney, 1998; Alesch et al. 2001; Chang and Falit-Baiamonte, 2002). Post disaster policies such as relocations after disasters in 
certain instances can limit the income opportunities to re-settlers in new locations (Arnal et al, 2013). The exclusion of households - based on gender, ethnicities etc. - from the reconstruction such as access to reconstruction aid can also limit the income opportunities of affected households leaving such households in poverty (Aldrich, 2010; Becchetti and Castriota, 2011, Kammerbauera and Wamslerb, 2017).

Only few studies attempted to reveal causal connection of recovery and distribution impacts. In a cross-country study, Cuaresma et al (2008) observe that natural disaster recovery benefits negatively associate with low income. Landry's study (Landry et al., 2007) investigating the return migration decisions of the evacuees of 2005 hurricane Katrina in the Unites States from the Gulf region finds that higher proportion of middle income families were planning to return and the low income families have shown a lower willingness to return. Fussell (2015)'s review of research on mobility - evacuation and migration - long after Katrina supports the contention that disaster driven migrants are more likely among minorities and economically disadvantage people. This research also finds that recovery for different segments of the population is driven by different mechanisms. Shaughnessy, White and Brendler (2010) have analyzed the income distribution effect of hurricane Katrina in New Orleans in the short and long time after the event using income density function approach - New Orleans and the United States pre-and post-event. It is evident that the event causing a right skewed income distribution in long term and suggestive of high skilled in-migrations after the disaster. Munoz and Tale (2016) investigated distribution of recovery funds for flood damaged property acquisition after 2008 Midwest flood in Iowa using spatial econometric modelling. This research finds that the households in high social vulnerability areas were less likely to receive full financial compensation and endure longer period for receiving acquisition funds. Lower recovery rates of the damaged property are observed in the areas with high number of elderly and Hispanic residents.

\subsection{Sri Lanka Context}

Sri Lanka is a lower middle-income country with per capita income of 13,800 US\$ (PPP) (IMF, 2016). Out of 21.2 million people, $4.1 \%$ live below the national poverty line 
(Department of Census and Statistics, 2016). In 2004, the catastrophic Indian Ocean tsunami caused death of 35,500 and more than one million people were affected. Infrastructure facilities - houses, public buildings, hospitals, hotels, fishery harbors, roads, railways, power, telecommunication, water supply and sanitation facilities - were severely damaged and the overall economic losses totaled USD 1.5 billion, approximately $5 \%$ of the country's GDP (Department of Census and Statistics, 2005). Thirteen coastal districts out of 14 coastal districts in the country were affected and tourism and fisheries were the most seriously affected sectors; 75000 people engaged in fishing lost their main income and tourism sector experienced 20\% lower earnings and 3\% fewer arrivals ${ }^{29}$ in 2005 as compared to pre-tsunami (Ministry of Environment, 2009).

The reconstruction after tsunami in Sri Lanka was planned and coordinated through a special institutional structure: The Task Force to Rebuild the Nation (TAFREN), later renamed as the Reconstruction and Development Agency (RADA) (GoSL, 2005, 2006). The government of Sri Lanka initially estimated the total reconstruction investment need of USD 2 billion including an ambitious build-back-better long-term reconstruction program (GOSL, 2005). The rebuilding after the tsunami was financed mainly by external aid and loans. Most of the funds were allocated for housing (45\%), livelihood (18\%) and the rest for asset replacement (Swedish International Development Agency [SIDA], 2009). Reconstruction activities were undertaken under the special programs until 2008 and the remaining activities were undertaken later under the government development program. Due to the pressure to satisfy beneficiary expectations, the reconstruction was accelerated (Khasalamwa and Boano, 2009) and reconstruction in south and west in the country - the treatment districts in this paper - was almost completed by the end of 2008 (Jayasuriya and McCawley, 2010). The internal conflict prevailed in Sri Lanka for more than two decades - internal conflict between armed group Liberation Tigers of Tamil Elam (LTTE) and the government troops - ended by the end of 2009.

\footnotetext{
${ }^{29}$ This is a remarkably small decrease in arrivals as compared to the reduced earnings from the tourism sector in the post disaster. The tourist arrivals account for every single visit with at least a single overnight stay in the country. International aid played a major role in the post disaster reconstruction in Sri Lanka and aid agency staff visiting the country after the disaster were most likely included in these counts.
} 


\subsection{Methodology}

Our methods of analysis include two extensions to Difference-in-Difference (DID) methods used in the program evaluation studies literature. First we apply quantile Difference in Difference method (QDID) to isolate the distributional effect of tsunami recovery. The QDID method relies on the standard DID model assumptions and additional assumptions to precisely isolate the distributional effect. The standard DID model treat groups and time symmetrically - for a particular scaling of the outcomes, the mean of individual outcomes in the absence of the treatment is additive in group and time indicators -and imposes common trend assumption on the data generating process. In addition to these restrictive model assumptions, the QDID relies also on rank preservation assumption: relative value of -rank-of the potential outcome for a given individual to be the same regardless of whether that individual is in the treatment or in the control groups. If these model assumptions are preserved, for any fixed percentile, the estimated treatment effect in quantile regression is the horizontal distance between two cumulative distribution functions of treatment and control groups.

This study applies both conditional (CQTEs) and unconditional (UCQTEs) quantile regression in Diff-in-Diff specification for each quantile. In conditional quantile estimation regression, the placement of the households across quantiles is based on the unobservable in the model (outcome distribution conditioned on the mean of the other covariates). The conditional quantile estimates can be interpreted as the relationship of the treatment variable with the conditional outcome distribution.

Unlike linear regression model that estimates the conditional expectations of outcome, the quantile regression model (Koenker and Bassett, 1978, Chernozhukov and Hanses, 2006) estimates the outcome at a different point in the conditional distribution which is a linear function of the covariates. The model specification takes the form below.

$q^{\tau} Y_{i d t}=\beta_{1}^{\tau}+\beta_{2}^{\tau}$ Post $_{i} T_{d}+\beta_{3}{ }_{3}^{\tau} \delta_{t}+\beta_{4}^{\tau} X_{i d t}+\beta_{5}^{\tau} \gamma_{d}+U_{i d t}^{\tau}$

$q^{\tau} Y_{i d t}$ is the outcomes of interest (household monthly consumption and household monthly income) at $\tau$ th quantile. The unit observed is household $i$, in district $d$ and time t. $T_{d}$ is the treatment dummy defining membership in the treatment cross section 
(affected $=1$, not affected $=0$ ) and $U_{i d t}$ are the unobserved affects. The treatment group is defined for households in seven affected districts (Colombo, Gampaha, Kalutara, Galle, Matara, Hambantota and Puttlam). Post ${ }_{i}$ is a dummy variable to distinguish the sample by pre- and post-treatment. $\beta_{2}$ is the coefficient of interest to isolate the treatment effect. As the treatment effects are naturally heterogeneous across households depending on their characteristics, the household socio economic and demographic characteristics $\left(X_{i d t}\right)$ are used (sex, age, years of education, ethnicity of the household head, and household size) in the model to control for such heterogeneity. This study uses the Parente and Santos Silva (2016) method to estimate the standard errors that are robust to heteroscedasticity and intra-cluster correlation.

Concerning the policy relevance of the estimates, the unconditional quantile estimations (UCQTEs) are preferred to the conditional quantile estimates. We estimate unconditional quantiles using the generalized Quantile regression (GQR) method proposed by Powell (2017). This method estimates the standard errors where treatment effects are "conditional" on the treatment variables but unconditional on the "control variables". Thus, UCQTEs are interpreted as the relationship of treatment with unconditional outcome distribution; therefore our inferences mainly rely on the UCQTEs.

To isolate the quantile treatment effect, the change-in-change approach (CIC) is our second estimation method which is a special case of DID (Athey and Imbens, 2006; Melly, and Santangelo, 2015). The CIC method relaxes more restrictive assumptions in QDID; as compared to DID, CIC method treats groups and time periods asymmetrically, relaxes the parallel trend assumption, but the rank preservation assumption is still maintained. The CIC model proposed by Athey and Imbens (2002) is non-parametrically estimated. This method uses the entire "before" and "after" outcome distributions in the control group to non-parametrically estimate the change over time that occurred in the control group and recovers the whole distribution of the counterfactual outcome. This method is applied to quantiles; computing the counterfactual distribution by adding the change over time at the $\mathrm{q}^{\text {th }}$ quantile of the control group to the $\mathrm{q}^{\text {th }}$ quantile of the first-period treatment group. This estimation is relatively straightforward in the absence of covariates. A recent method proposed by Melly and Santangelo (2015) suggests a semi parametric estimator; 
they incorporate covariates in the Athey and Imbens (2006)'s procedure to obtain unconditional estimates. Concerning the demerits of QDID to precisely estimate the distribution impacts as discussed in the program evaluation literature (Athey and Imbens, 2006), we estimates CIC model using preliminary STATA codes shared by the researchers (Melly and Santangelo, 2015). ${ }^{30}$

To examine the implications of tsunami disaster recovery on income distribution, we analyze the inequality measures in the pre and post disaster periods. Lorenz curve and Gini coefficients are widely used inequality measures and probability density function is also used in number of studies (Madden, 2000, Campano and Salvatore, 2006, Shaughnessy, White and Brendler, 2010). We calculate the Gini coefficient of income and consumption expenditure for treatment districts, control districts and the whole sample during pre-and post- disaster periods. Afterwards, we compare the extent of deviation of income/consumption distribution from perfect equality in the pre and post disaster periods. The paper also estimates the coefficient of variation, a measure which is more sensitive to the changes in the upper tail. We plot the Lorenz curves to show the distributional effects graphically.

Our data come from the five national household income and expenditure surveys of 1995, 2002, 2006, 2009 and 2012. The study is confined to only seven affected districts out of total 13 affected districts; survey data are not available on the remaining districts as they were inaccessible due to the prevailing conflict. The remaining coastal districts were directly affected by the internal conflict in the country, and the surveys have not been conducted there. Due to inconsistency of survey instruments across surveys, our household income includes only employment income, net income from other income sources (agricultural and non-agricultural activities) and transfers to the household, but excludes the income from asset liquidation and income from credit. The consumption includes all household expenditures excluding investments on assets (land, housing) (Appendix table 4.1).

\footnotetext{
${ }^{30}$ We thank Professor Blaise Melly for generously sharing the CIC STATA codes. Researchers work on this method is still in progress.
} 


\subsection{Results}

Table 4-1 presents the summary statistics. Table 4.2 and 4.3 show the results of QDID estimation method. Table 4.5 shows the estimates of CIC method, while Table 4-2 and 43 show the estimates of income and consumption recovery in each quantile respectively using both conditional and unconditional quantile regression methods for three post recovery years: 2006, 2009 and 2012. Log normal quantile regression models are also estimated to evaluate the elasticities. The results are reported in percentage column in tables 4-2 and 4-3.

The summary statistics in the table 4-1 show that the households in all quantiles are almost similar according to the household characteristics such as gender and age of the household head and the ethnicity (column 3, 4 and 7 respectively). The households in the lowest and highest quantiles appear smaller in size (column 6) compared to the households in the middle quantiles. Considering the exposure to the tsunami disaster, our treatment group has higher representation from the high-income households compared to the households in the lowest quantiles (column 8). It also appears that there is a higher representation of households in the post tsunami from the higher and the lower quantiles compared to those in the middle quantiles (column 9).

\subsubsection{Income recovery distribution}

\section{QDID method: Conditional quantile regression}

Table 4-2 presents the recovery across the income quantiles. The conditional quantile regression results are given in the results columns 1-6. The estimates in the column 1 show significant income (except the lowest quantile) increase across quantiles favoring the highest quantiles more compared to the lower quantiles. Similar observations are made considering the percentage scale in the column 2 . These results indicate that highincome households -as conditioned on observed characteristics - are better off than the household in the lower quantiles in the year just after the disaster. This clearly indicates rich favored recovery that warns increase in inequality. Similar pattern appears in the column 3 and 5 for other post disaster years. Considering the long-lasting recovery of 
households in each quantile, all quantiles show a decline of recovery benefits in year 2009 and again increase in 2012 similarly to the variation of recovery of the average household reported by De Alwis and Noy (2016). The recovery of households in the middle of the distribution in the log linear model - third and fourth quantile in column 4 and 6 - shows a negative recovery compared to positive recovery for absolute income. ${ }^{31}$ Nevertheless, recovery of the lowest and highest income group in all post disaster years is statistically significant and biased to high income groups.

\section{QDID method: Unconditional quantile regression}

The unconditional quantile regression estimates are presented in the columns 7-12 of the table 4-2. The first year of the post disaster (2006) in column 7 shows a " $U$ " shape distribution of recovery across income quantiles; higher significant recovery benefits accrued to the lowest income quantile (Sri Lankan Rupees [LKR] 12121) and then reduction across quantiles up to $5^{\text {th }}$ quantile (LKR 4126) and increasing benefits to high income groups (LKR 19956 for 99 th percentile). The recovery in the years 2009 and 2012 (column 9 and 11 respectively) show that the recovery in the lowest income quantile is not sustained and higher income groups show better recovery with much higher benefits compared to lower quantiles in both post disaster years. Similar to the reported average household recovery, all income groups plummeted in 2009 - the year that government intensified combating terrorism. The post disaster periods 2009 and 2012 (in column 9 and 11) show much higher benefits to high income groups and is suggestive of a widening gap between rich and poor later in the post disaster years (figure4-1). However, elasticity of income recovery estimates in 2006 (column 8) show inverse relationship of recovery across quantiles; proportion of income recovery for low income groups is higher (9.4\%) and it is getting lower along up to high income groups $\left(0.43 \%\right.$ in the $99^{\text {th }}$ percentile $)$. A similar pattern is observed for the post disaster years 2009 and 2012 except the lowest quantile and households in the 99\% of the income distribution (in the column 10 and 12). Deviating from the observed pattern of other quantiles, the income recovery of the

\footnotetext{
31 One possible explanation for inconsistent observations available to us is that tour log model is nonlinear as compared to restrictive linear model assumption in QDID method. Melly, and Santangelo (2015)'s changes-inchanges model remedy the more restrictive assumptions in QDID method including the linear difference in difference model.
} 
household in the lowest quantile turn to totally opposite direction and recovery of the households in the $99 \%$ of the income distribution stays lower than the $9^{\text {th }}$ quantile in both 2009 and 2012. Again, distribution of recovery benefits across post disaster years shows a drop in the year 2009; these results are depicted in figure 4-2.

\section{CIC method}

As CIC method of Melly and Santangelo (2015) is still at developmental stages, this method up to present date allows us to use only two periods in the model. Table 4-4 shows the estimates using CIC method using pre and post disaster periods. Column 1 and 3 show the absolute income and income recovery as a percentage of average income, respectively; both estimates reveal a recovery of income biased to low income groups. The recovery for lowest income households is approximately 4 times of their average income and for highest income households it is $50 \%$ of the average income. These results are depicted graphically in figures 4-3 and 4-4.

\subsubsection{Consumption recovery distribution}

QDID method: Conditional quantile regression

Table 4-3 provides the consumption recovery across quantiles. The conditional quantile estimates are given in columns 1-6. The most recent post disaster observation (year 2006 in column 1) shows an increasing benefit across quantiles towards the highest quantiles as observed for the income recovery (LKR 334 -8975). The other post disaster years 2009 and 2012 in column 3 and 5 respectively show a similar pattern (except highest quantile in year 2012). The recovery across almost all quantiles is statistically insignificant in 2009. Even though there is a decline of consumption in 2009, the recovery in 2012 is higher than the recovery achieved in the year 2006 (column1 and 5). The consumption recovery across post disaster years again shows a similar pattern of the income recovery (column 1, 3, 5).

However, a nuanced picture appears when log normal model is used; negative consumption recovery is observed as opposed to non-log model and most of the estimates are statistically insignificant. The estimates across all quantiles in year 2006 
are positive but statistically non-significant; the estimates in year 2009 and 2012 are negative, and statistically significant only for households in middle - 5, 6, 7 quantiles- and the right end $-99^{\text {th }}$ percentile - of the distribution. These results indicate a harm biased to middle income and rich households.

\section{QDID method: Unconditional quantile regression}

Unconditional regression estimates show a " $U$ " shape distribution of consumption recovery across lowest to highest quantile in post disaster years 2006 (LKR 1017, 12907 in column 7, except the first quantile) and 2009 (LKR 483, 4550 in column 9). Figure 4-5 shows the observed consumption recovery across quantiles in each year. Similar "U" shape curve is revealed in the estimates as percentage of consumption for these post disaster years $(22 \%, 24 \%$ in column 8 and 13\%, 9\% in column 10). Figure 4-6 shows the observations for post disaster years 2006 and 2009. In the post disaster 2009, the households in the lowest and the highest quantile's recovery (except the negative recovery in the $6^{\text {th }}$ quantile) only are statistically significant (column 10). Further, in the latest post disaster year 2012, the recovery among middle quantiles is also statistically non-significant and it is sustained only among the higher quantiles (column 12). Recovery in the higher quantiles ( $8^{\text {th }}$ onwards) in 2012 bounce back to the level of the first post disaster year or even further extended after a reduction in year 2009. This recovery pattern is similar to the observed income recovery among almost all quantiles.

\section{CIC method}

Column 9 and 10 in the table 4-4 shows the estimates revealed in CIC method incorporating Consumer Price Index(CPI) by consumption components (food energy, housing, other non-food) (Parker, 2018) in the model to control for the consumption variation due variation of consumption basket across income groups. The consumption recovery is positive across all households groups but favoring the rich; the estimates are statistically significant only above median consumption. The log-normal estimates in column 11 and 12 show highest recovery to lowest tail of the distribution, then reducing the positive recovery up to $8^{\text {th }}$ quantile and a slight upward turn for households in the uppermost group of the consumption distribution. However, recovery is statistically 
significant only for the households in the lowest and upper tail $-8^{\text {th }}$ and $9^{\text {th }}$ - of the consumption distribution. These patterns are depicted in the figures 4-7 and 4-8. According to these estimates, recovery has a consumption gap reducing effect between rich and poor in the long term.

\subsubsection{Inequality of income and consumption}

The inequality measures for the whole sample and separately for the treated and control districts over the survey periods are given in the Figure 4-9 and 4-10 (a b) respectively. The Gini coefficient of household income for the whole sample (figure 4-9) shows an increase of inequality in 2002 compared to the year 1995 then a reduction in the first post disaster year 2006. Again, an increase and reduction of Gini coefficient is observed in year 2009 and 2012 respectively. However, inequality in 2012 remains higher than the inequality in 1995. The coefficient of variation, which is more sensitive to the higher income groups shows similar trends, but the coefficient in 2012 is lower than 1995 . In contrast to income, the Gini coefficient for consumption shows an increase of inequality up to the first post disaster year and then decline in later post disaster years. The latest is still higher than the year 1995. The coefficient of variation for consumption also shows a reduction during post disaster years and in the recent year remains lower than in 1995. These results clearly show an increase of inequality in the first post disaster year and then a reduction of inequality across the post disaster years.

Comparing the income of tsunami affected and not affected households separately in the Figure 4-10 ( $a$ and $b$ ), the affected region (Figure 4-10 a) appears more equal than the unaffected regions. Comparing the two groups in the pre and post disaster years, the affected region's income inequality increased from 1995 to 2002, but reduced in the post disaster period and ended up lower than the first survey year. In contrast, the nonaffected region's inequality increased over the survey years. The coefficient of variation (figure 4-10 b) shows a similar pattern of Gini coefficient for both groups.

The consumption distribution follows the same pattern of income distribution pre tsunami; but both region's Gini coefficient is reduced over the post disaster years. Nevertheless, the affected region's Gini coefficient remains lower than the not affected 
region in the recent post disaster year 2012. The coefficient of variation follows an almost similar pattern (Figure 4-10 b).

The inequality measures indicate a reduction of inequality in affected compared to unaffected regions during the post tsunami period. These observations are also depicted in the Lorenz curves in appendix figures 4-3 to 4-8.

\subsection{Robustness analysis}

Parallel trend in pre-disaster period between each pair of treatment and control quantiles is a pre-condition for precise identification of the causal effect in the QDID method. To check the validity of this assumption, a placebo test analysis was conducted for each quantile treating the treatment group a year prior to the treatment (Using the treatment and year 2002 interaction variable). The results are given in the table 4-5. The coefficients revealed for both income and consumption for all quantiles are not statistically significant providing evidence for the validity of parallel trend assumption. Further, normalised income for selected quantiles $\left(2^{\text {nd }}, 5^{\text {th }}, 7^{\text {th }}\right.$ and $9^{\text {th }}$ quantiles$)$ in figures $4-11$, 4-12, 4-13, and 4-14 show a much closer trend of the residual income between the two groups during pre-disaster period. Similar observations appear for normalized consumption of households in figures 4-15, 4-16, 4-17, and 4-18.

\subsection{Conclusions}

This study sets out to determine the distributional impacts of catastrophic Indian Ocean tsunami in Sri Lanka. Our empirical inquiry adopts two methods; the quantile difference in difference method (QDID) estimating both conditional (CQEs) and unconditional quantile (UCQEs) models and the change-in-change method (CIC) estimating unconditional quantile models.

Evidence for a rich-biased recovery from the catastrophic tsunami in Sri Lanka emerge from the estimated conditional QDID models considering the absolute income and consumption. As the observations on conditional outcome and their distributions are less 
desirable for policy relevant implications, our inferences primarily rely on the unconditional model estimates in relative terms.

Overall, we observe a long term income recovery across all income groups that is biased to low income groups in relative terms in our empirical analysis. The results seem robust to the methods of analysis-UCQE and CIC. Our estimates for consumption also show a similar direction of recovery in spite of some variation in estimates from different empirical methods. Estimates using UQDID method shows a "U" shape recovery distribution across quantile up to $5^{\text {th }}$ year of post disaster, but sustenance of recovery up to $8^{\text {th }}$ post disaster year appears only among rich households. Across all post disaster years, the CIC estimates reveals a poor biased consumption recovery. Our empirical observations are reinforced by observed inequality measures of affected and unaffected regions in the pre and post disaster periods.

Discussion on disaster recovery scenarios in the literature is vast, but the causal connections are complex and less well known. In line with the literature that claims financing and quality of reconstruction as critical causal factors for long lasting recovery from a catastrophic disaster, we reemphasize reconstruction aid (De Alwis and Noy, 2016). The returns to reconstruction investments could be widespread, and our observation of skewed recovery reflects the distribution of such returns across households in the affected regions. The channels through which aid flows to the micro level can be manifold. Key factors include institutions, economic environment, income opportunities, type of household assets, and returns to their assets. Special reconstruction authorities, decentralized reconstruction decisions, and involvement of community based organizations and the private sector in reconstruction are some of the key features. As yet, our micro study is powerless to establish a robust causal story; further work is required for bridging the micro and macro observations in the post disaster period. 
Table 4-1 Summary statistics for quantiles

\begin{tabular}{|c|c|c|c|c|c|c|c|c|c|}
\hline Income quantile & $\begin{array}{l}\text { (i) } \\
\text { Total Income } \\
\text { in SL Rs. }\end{array}$ & $\begin{array}{l}\text { (ii) } \\
\text { Total } \\
\text { consumption in } \\
\text { SL Rs. }\end{array}$ & $\begin{array}{l}\text { (iii) } \\
\text { Sex of } \\
\text { Household } \\
\text { head (Male) }\end{array}$ & $\begin{array}{l}\text { (iv) } \\
\text { Age of } \\
\text { Household } \\
\text { head }\end{array}$ & $\begin{array}{l}\text { (v) } \\
\text { Years of } \\
\text { education of } \\
\text { the } \\
\text { Household } \\
\text { head }\end{array}$ & $\begin{array}{l}\text { (vi) } \\
\text { Household } \\
\text { size }\end{array}$ & $\begin{array}{l}\text { (vii) } \\
\text { Ethnicity } \\
\text { Singhalese }\end{array}$ & $\begin{array}{l}\text { (viii) } \\
\text { Proportion of } \\
\text { affected } \\
\text { households }\end{array}$ & $\begin{array}{l}\text { (ix) } \\
\text { Proportion of } \\
\text { household's } \\
\text { post tsunami }\end{array}$ \\
\hline 1 & -41 & 7870 & .80 & 48 & 6.8 & 4.3 & .80 & .18 & .44 \\
\hline 2 & 8 & 9813 & .76 & 50 & 7.1 & 4.2 & .77 & .12 & .87 \\
\hline 3 & 93 & 11880 & .79 & 50 & 7.2 & 4.3 & .85 & .10 & .82 \\
\hline 4 & 1519 & 8190 & .79 & 50 & 6.8 & 4.5 & .85 & .46 & .20 \\
\hline 5 & 3358 & 8915 & .78 & 51 & 6.9 & 4.6 & .81 & .58 & .31 \\
\hline 6 & 5171 & 9658 & .77 & 51 & 7.1 & 4.6 & .81 & .62 & .42 \\
\hline 7 & 7559 & 10848 & .77 & 51 & 7.2 & 4.6 & .81 & .67 & .55 \\
\hline 8 & 11088 & 12801 & .76 & 52 & 7.4 & 4.6 & .79 & .73 & .68 \\
\hline 9 & 17093 & 14743 & .76 & 51 & 7.5 & 4.5 & .80 & .81 & .80 \\
\hline 10 & 37294 & 18790 & .76 & 51 & 8.1 & 4.4 & .81 & .90 & .90 \\
\hline Average & 8310 & 11244 & .78 & 50 & 7.2 & 4.5 & .81 & .52 & .57 \\
\hline
\end{tabular}


Table 4-2 Income recovery across quantiles

\begin{tabular}{|c|c|c|c|c|c|c|c|c|c|c|c|c|}
\hline \multirow{2}{*}{$\begin{array}{l}\text { Year } \\
\text { Quantile }\end{array}$} & \multicolumn{6}{|c|}{ Conditional (cluster bootstrap ) QR } & \multicolumn{6}{|c|}{ Unconditional (Robust) QR } \\
\hline & 2006 & $\%$ & 2009 & $\%$ & 2012 & $\%$ & 2006 & $\%$ & 2009 & $\%$ & 2012 & \\
\hline 0.1 & $\begin{array}{l}2601 \\
(1673)\end{array}$ & $\begin{array}{l}0.84 \\
(0.26)^{* * *}\end{array}$ & $\begin{array}{l}2616 \\
(1525)^{*}\end{array}$ & $\begin{array}{l}0.81 \\
(0.22)^{* * *}\end{array}$ & $\begin{array}{l}5033 \\
(2997) *\end{array}$ & $\begin{array}{l}0.77 \\
(0.27)^{* * *}\end{array}$ & $\begin{array}{l}12121 \\
(53)^{* * *}\end{array}$ & $\begin{array}{l}9.40 \\
(0.01)^{* * *}\end{array}$ & $\begin{array}{l}-4301 \\
(66)^{* * *}\end{array}$ & $\begin{array}{l}-66.7 \\
(0.18)^{* * *}\end{array}$ & $\begin{array}{l}-1507 \\
(43)^{* * *}\end{array}$ & $\begin{array}{l}-12.7 \\
(0.05)^{* * *}\end{array}$ \\
\hline 0.2 & $\begin{array}{l}3114 \\
(1238)^{* * *}\end{array}$ & $\begin{array}{l}0.80 \\
(0.35)^{* * *}\end{array}$ & $\begin{array}{l}3059 \\
(1179)^{* * *}\end{array}$ & $\begin{array}{l}0.08 \\
(0.27)\end{array}$ & $\begin{array}{l}6760 \\
(2700)^{* * *}\end{array}$ & $\begin{array}{l}0.13 \\
(0.24)\end{array}$ & $\begin{array}{l}4847 \\
(2)^{* * *}\end{array}$ & $\begin{array}{l}9.65 \\
(0.006) \\
* * *\end{array}$ & $\begin{array}{l}90 \\
(5)^{* * *}\end{array}$ & $\begin{array}{l}7.03 \\
(0.005) \\
* * *\end{array}$ & $\begin{array}{l}10071 \\
(2)^{* * *}\end{array}$ & $\begin{array}{l}8.82 \\
(0.001)^{* * *}\end{array}$ \\
\hline 0.3 & $\begin{array}{l}3297 \\
(1236)^{* * *}\end{array}$ & $\begin{array}{l}0.89 \\
(0.39)^{* * *}\end{array}$ & $\begin{array}{l}3289 \\
(1123)^{* * *}\end{array}$ & $\begin{array}{l}-0.12 \\
(0.32) \\
\end{array}$ & $\begin{array}{l}8572 \\
(3048) * * *\end{array}$ & $\begin{array}{l}-0.03 \\
(0.30) \\
\end{array}$ & $\begin{array}{l}7510 \\
(171)^{* * *}\end{array}$ & $\begin{array}{l}5.5 \\
(0.01)^{* * *}\end{array}$ & $\begin{array}{l}3883 \\
(54)^{* * *}\end{array}$ & $\begin{array}{l}4.6 \\
(0.02)^{* * *}\end{array}$ & $\begin{array}{l}3734 \\
(306)^{* * *}\end{array}$ & $\begin{array}{l}4.9 \\
(0.02) * * *\end{array}$ \\
\hline 0.4 & $\begin{array}{l}3489 \\
(1395)^{* * *}\end{array}$ & $\begin{array}{l}1.10 \\
(0.38)^{* * *}\end{array}$ & $\begin{array}{l}3477 \\
(1237)^{* * *}\end{array}$ & $\begin{array}{l}-0.26 \\
(0.48)\end{array}$ & $\begin{array}{l}10466 \\
(3041)^{* * *}\end{array}$ & $\begin{array}{l}-0.11 \\
(0.43) \\
\end{array}$ & $\begin{array}{l}5167 \\
(294)^{* * *}\end{array}$ & $\begin{array}{l}1.82 \\
(0.14)^{* * *}\end{array}$ & $\begin{array}{l}4617 \\
(256) * * *\end{array}$ & $\begin{array}{l}1.72 \\
(0.13) * * *\end{array}$ & $\begin{array}{l}10582 \\
(439)^{* * *}\end{array}$ & $\begin{array}{l}2.45 \\
(0.13) * * *\end{array}$ \\
\hline 0.5 & $\begin{array}{l}3767 \\
(2056) *\end{array}$ & $\begin{array}{l}2.25 \\
(1.40) \\
\end{array}$ & $\begin{array}{l}3486 \\
(1309)^{* * *}\end{array}$ & $\begin{array}{l}0.15 \\
(0.88)\end{array}$ & $\begin{array}{l}12378 \\
(3722)^{* * *}\end{array}$ & $\begin{array}{l}0.28 \\
(0.84)\end{array}$ & $\begin{array}{l}4126 \\
(178)^{* * *}\end{array}$ & $\begin{array}{l}0.87 \\
(0.3)^{* * *}\end{array}$ & 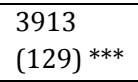 & $\begin{array}{l}0.84 \\
(03)^{* * *}\end{array}$ & $\begin{array}{l}9883 \\
(240)^{* * *}\end{array}$ & $\begin{array}{l}1.5 \\
(0.3) * * *\end{array}$ \\
\hline 0.6 & $\begin{array}{l}4353 \\
(2220)^{* * *}\end{array}$ & $\begin{array}{l}2.92 \\
(3.69) \\
\end{array}$ & $\begin{array}{l}3293 \\
(1822)^{* * *}\end{array}$ & $\begin{array}{l}0.46 \\
(0.84) \\
\end{array}$ & $\begin{array}{l}14499 \\
(3901)^{* * *}\end{array}$ & $\begin{array}{l}0.57 \\
(0.90) \\
\end{array}$ & $\begin{array}{l}8922 \\
(33)^{* * *}\end{array}$ & $\begin{array}{l}0.72 \\
(0.02)^{* * *}\end{array}$ & $\begin{array}{l}5838 \\
(137) * * *\end{array}$ & $\begin{array}{l}0.71 \\
(0.02)^{* * *}\end{array}$ & $\begin{array}{l}13068 \\
(276)^{* * *}\end{array}$ & $\begin{array}{l}1.24 \\
(0.02) * * *\end{array}$ \\
\hline 0.7 & $\begin{array}{l}5350 \\
(2490)^{* *}\end{array}$ & $\begin{array}{l}1.65 \\
(1.49)\end{array}$ & $\begin{array}{l}3853 \\
(1847)^{* *}\end{array}$ & $\begin{array}{l}0.72 \\
(0.80)\end{array}$ & $\begin{array}{l}17154 \\
(5004)^{* * *}\end{array}$ & $\begin{array}{l}0.86 \\
(0.78)\end{array}$ & $\begin{array}{l}5726 \\
(211)^{* * *}\end{array}$ & $\begin{array}{l}0.64 \\
(0.02)^{* * *}\end{array}$ & $\begin{array}{l}5610 \\
(179)^{* * *}\end{array}$ & $\begin{array}{l}0.63 \\
(0.02)^{* * *}\end{array}$ & $\begin{array}{l}12691 \\
(252)^{* * *}\end{array}$ & $\begin{array}{l}1.10 \\
(0.02) * * *\end{array}$ \\
\hline 0.8 & $\begin{array}{l}6746 \\
(2886) * * *\end{array}$ & $\begin{array}{l}1.64 \\
(1.36)\end{array}$ & $\begin{array}{l}4679 \\
(2098) * *\end{array}$ & $\begin{array}{l}1.24 \\
(0.93)\end{array}$ & $\begin{array}{l}20641 \\
(4961)^{* * *}\end{array}$ & $\begin{array}{l}1.33 \\
(0.93)\end{array}$ & 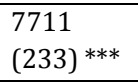 & $\begin{array}{l}0.61 \\
(0.02)^{* * *}\end{array}$ & $\begin{array}{l}6803 \\
(188) * * *\end{array}$ & $\begin{array}{l}0.55 \\
(0.01)^{* * *}\end{array}$ & $\begin{array}{l}15367 \\
(233)^{* * *}\end{array}$ & $\begin{array}{l}0.98 \\
(0.01) * * *\end{array}$ \\
\hline 0.9 & $\begin{array}{l}9578 \\
(2769)^{* * *} \\
\end{array}$ & $\begin{array}{l}2.08 \\
(1.74) \\
\end{array}$ & $\begin{array}{l}5977 \\
(2207)^{* * *} \\
\end{array}$ & $\begin{array}{l}1.88 \\
(1.74) \\
\end{array}$ & $\begin{array}{l}26473 \\
(4812)^{* * *}\end{array}$ & $\begin{array}{l}1.94 \\
(1.45) \\
\end{array}$ & $\begin{array}{l}9958 \\
(299)^{* * *} \\
\end{array}$ & $\begin{array}{l}0.53 \\
(0.01)^{* * *} \\
\end{array}$ & $\begin{array}{l}8274 \\
(267)^{* * *} \\
\end{array}$ & $\begin{array}{l}0.46 \\
(0.01)^{* * *}\end{array}$ & $\begin{array}{l}20909 \\
(749)^{* * *}\end{array}$ & $\begin{array}{l}0.90 \\
(0.01)^{* * *}\end{array}$ \\
\hline 0.99 & $\begin{array}{l}16586 \\
(4846)^{* * *}\end{array}$ & $\begin{array}{l}2.95 \\
(1.33)^{* * *}\end{array}$ & $\begin{array}{l}11321 \\
(5705)^{*}\end{array}$ & $\begin{array}{l}2.92 \\
(1.14)^{* *}\end{array}$ & $\begin{array}{l}34264 \\
(4706)^{* * *}\end{array}$ & $\begin{array}{l}2.77 \\
(1.78) * * *\end{array}$ & $\begin{array}{l}19956 \\
(688)^{* * *}\end{array}$ & $\begin{array}{l}0.43 \\
(0.003) \\
* * *\end{array}$ & $\begin{array}{l}14779 \\
(65)^{* * *}\end{array}$ & $\begin{array}{l}0.39 \\
(0.002)\end{array}$ & $\begin{array}{l}34844 \\
(359)^{* * *}\end{array}$ & $\begin{array}{l}0.64 \\
(0.004)^{* * *}\end{array}$ \\
\hline $\begin{array}{l}\text { Average } \\
\text { Treatment } \\
\text { effect }\end{array}$ & \multicolumn{2}{|l|}{$\begin{array}{l}7022 \\
(2898)^{* * *} \\
{[879,13165]}\end{array}$} & \multicolumn{2}{|l|}{$\begin{array}{l}5787 \\
(2474)^{* * *} \\
{[543,11032]}\end{array}$} & \multicolumn{2}{|l|}{$\begin{array}{l}15066 \\
(4802) * * * \\
{[4887,25245]}\end{array}$} & & & & & & \\
\hline $\begin{array}{l}\text { Gini } \\
\text { Coefficient of } \\
\text { affected } \\
\text { districts } \\
\end{array}$ & \multicolumn{2}{|l|}{0.48} & \multicolumn{2}{|l|}{0.46} & \multicolumn{2}{|l|}{0.43} & & & & & & \\
\hline
\end{tabular}

ethnicity of the household head, and household size. The household income (outcome variable of interest) include only paid, agricultural and non-agricultural income, remittances, transfers, dividends, property rents and cash receipts and exclude loans, sale of assets, withdrawal of savings, insurance compensation and other adhoc gains (see appendix 1). 
Table 4-3 Consumption recovery across quantiles

\begin{tabular}{|c|c|c|c|c|c|c|c|c|c|c|c|c|}
\hline \multirow{3}{*}{$\begin{array}{l}\text { Year } \\
\text { Quantile } \\
0.1\end{array}$} & \multicolumn{6}{|c|}{ Conditional (cluster bootstrap method) QR } & \multicolumn{6}{|c|}{ Unconditional (robust) QR } \\
\hline & \multicolumn{2}{|l|}{2006} & \multicolumn{2}{|l|}{2009} & \multicolumn{2}{|l|}{2012} & \multirow{2}{*}{$\begin{array}{l}2006 \\
823 \\
(71)^{* * *}\end{array}$} & \multirow{2}{*}{$\begin{array}{l}\% \\
0.22 \\
(0.02)^{* * *}\end{array}$} & \multirow{2}{*}{$\begin{array}{l}2009 \\
483 \\
(226)^{* *}\end{array}$} & \multirow{2}{*}{$\begin{array}{l}\% \\
0.13 \\
(0.01)^{* * *}\end{array}$} & \multirow{2}{*}{$\begin{array}{l}\mathbf{2 0 1 2} \\
-23683 \\
(25861)\end{array}$} & \multirow{2}{*}{$\begin{array}{l}\% \\
-43.6 \\
(58.9)\end{array}$} \\
\hline & $\begin{array}{l}344 \\
(166) \text { ** }\end{array}$ & $\begin{array}{l}0.05 \\
(0.06)\end{array}$ & $\begin{array}{l}26 \\
(140)\end{array}$ & $\begin{array}{l}-0.02 \\
(0.04)\end{array}$ & $\begin{array}{l}769 \\
(531)\end{array}$ & $\begin{array}{l}-0.04 \\
(0.04)\end{array}$ & & & & & & \\
\hline 0.2 & $\begin{array}{l}537 \\
(205) * * *\end{array}$ & $\begin{array}{l}0.05 \\
(0.05)\end{array}$ & $\begin{array}{l}54 \\
(154)\end{array}$ & $\begin{array}{l}-0.03 \\
(0.04)\end{array}$ & $\begin{array}{l}1192 \\
(733)^{*}\end{array}$ & $\begin{array}{l}-0.05 \\
(0.04) \\
\end{array}$ & $\begin{array}{l}1017 \\
(53)^{* * *}\end{array}$ & $\begin{array}{l}0.21 \\
(0.01)^{* * *}\end{array}$ & $\begin{array}{l}408 \\
(56)^{* * *}\end{array}$ & $\begin{array}{l}0.09 \\
(0.01)^{* * *}\end{array}$ & $\begin{array}{l}-69330 \\
(44010) \\
\end{array}$ & $\begin{array}{l}-40.16 \\
(47.58) \\
\end{array}$ \\
\hline 0.3 & $\begin{array}{l}732 \\
(248) * * *\end{array}$ & $\begin{array}{l}0.06 \\
(0.05)\end{array}$ & $\begin{array}{l}87 \\
(171)\end{array}$ & $\begin{array}{l}-0.04 \\
(0.04)\end{array}$ & $\begin{array}{l}1776 \\
(863)^{* *}\end{array}$ & $\begin{array}{l}-0.05 \\
(0.04)\end{array}$ & $\begin{array}{l}936 \\
(86)^{* * *}\end{array}$ & $\begin{array}{l}0.16 \\
(0.01)^{* * *}\end{array}$ & $\begin{array}{l}191 \\
(63)^{* * *}\end{array}$ & $\begin{array}{l}0.03 \\
(0.01)^{* * *}\end{array}$ & $\begin{array}{l}-32871 \\
(25298)\end{array}$ & $\begin{array}{l}-87.6 \\
(130.1)\end{array}$ \\
\hline 0.4 & $\begin{array}{l}908 \\
(306)^{* * *}\end{array}$ & $\begin{array}{l}0.06 \\
(0.05)\end{array}$ & $\begin{array}{l}144 \\
(193)\end{array}$ & $\begin{array}{l}-0.05 \\
(0.04)\end{array}$ & $\begin{array}{l}2131 \\
(915)^{* * *}\end{array}$ & $\begin{array}{l}-0.06 \\
(0.03) *\end{array}$ & $\begin{array}{l}916 \\
(104) * * *\end{array}$ & $\begin{array}{l}0.13 \\
(0.01)^{* * *}\end{array}$ & $\begin{array}{l}129 \\
(91)\end{array}$ & $\begin{array}{l}0.02 \\
(0.01)\end{array}$ & $\begin{array}{l}-33984 \\
(32039)\end{array}$ & $\begin{array}{l}29.4 \\
(21.8)\end{array}$ \\
\hline 0.5 & $\begin{array}{l}1213 \\
(354) * * *\end{array}$ & $\begin{array}{l}0.06 \\
(0.05) \\
\end{array}$ & $\begin{array}{l}21 \\
(230) \\
\end{array}$ & $\begin{array}{l}-0.06 \\
(0.03) *\end{array}$ & $\begin{array}{l}1544 \\
(582)^{* * *}\end{array}$ & $\begin{array}{l}-0.08 \\
(0.04)^{* *}\end{array}$ & $\begin{array}{l}856 \\
(132)^{* * *}\end{array}$ & $\begin{array}{l}0.10 \\
(0.01)^{* * *}\end{array}$ & $\begin{array}{l}-87 \\
(85)\end{array}$ & $\begin{array}{l}0.01 \\
(0.01)\end{array}$ & $\begin{array}{l}-54275 \\
(35060)\end{array}$ & $\begin{array}{l}73.1 \\
(113.1)\end{array}$ \\
\hline 0.6 & $\begin{array}{l}1470 \\
(335)^{* * *}\end{array}$ & $\begin{array}{l}0.06 \\
(0.04)\end{array}$ & $\begin{array}{l}170 \\
(221)\end{array}$ & $\begin{array}{l}-0.06 \\
(0.03) *\end{array}$ & $\begin{array}{l}2875 \\
(1218) * * *\end{array}$ & $\begin{array}{l}-0.10 \\
(0.04)^{* * *}\end{array}$ & $\begin{array}{l}2970 \\
(2238)\end{array}$ & $\begin{array}{l}0.09 \\
(0.02)^{* * *}\end{array}$ & $\begin{array}{l}673 \\
(803)\end{array}$ & $\begin{array}{l}-0.006 \\
(0.01)\end{array}$ & $\begin{array}{l}-1459 \\
(1283)\end{array}$ & $\begin{array}{l}-0.32 \\
(0.03) * * *\end{array}$ \\
\hline 0.7 & $\begin{array}{l}2019 \\
(567) * * *\end{array}$ & $\begin{array}{l}0.07 \\
(0.06)\end{array}$ & $\begin{array}{l}283 \\
(258)\end{array}$ & $\begin{array}{l}-0.06 \\
(0.03) *\end{array}$ & $\begin{array}{l}3212 \\
(1164) * * *\end{array}$ & $\begin{array}{l}-0.11 \\
(0.04)^{* * *}\end{array}$ & $\begin{array}{l}2317 \\
(749) * * *\end{array}$ & $\begin{array}{l}0.14 \\
(0.2)^{* * *}\end{array}$ & $\begin{array}{l}648 \\
(259) * * *\end{array}$ & $\begin{array}{l}0.04 \\
(0.01)^{* * *}\end{array}$ & $\begin{array}{l}299 \\
(239)\end{array}$ & $\begin{array}{l}0.01 \\
(0.01)\end{array}$ \\
\hline 0.8 & 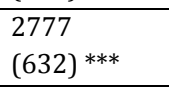 & $\begin{array}{l}0.07 \\
(0.05) \\
\end{array}$ & $\begin{array}{l}646 \\
(321)^{* *}\end{array}$ & $\begin{array}{l}-0.04 \\
(0.03) \\
\end{array}$ & $\begin{array}{l}4294 \\
(1861) *\end{array}$ & $\begin{array}{l}-0.09 \\
(0.05) \\
\end{array}$ & 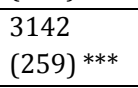 & $\begin{array}{l}0.19 \\
(0.02)^{* * *}\end{array}$ & $\begin{array}{l}1395 \\
(212)^{* * *}\end{array}$ & $\begin{array}{l}0.09 \\
(0.01)^{* * *}\end{array}$ & $\begin{array}{l}2571 \\
(146))^{* * *}\end{array}$ & $\begin{array}{l}0.16 \\
(0.01)^{* * *}\end{array}$ \\
\hline 0.9 & $\begin{array}{l}3658 \\
(817)^{* * *}\end{array}$ & $\begin{array}{l}0.06 \\
(0.06)\end{array}$ & $\begin{array}{l}1159 \\
(726)\end{array}$ & $\begin{array}{l}-0.04 \\
(0.04)\end{array}$ & $\begin{array}{l}5560 \\
(1819) * * *\end{array}$ & $\begin{array}{l}-0.11 \\
(0.07)\end{array}$ & $\begin{array}{l}5237 \\
(404) * * *\end{array}$ & $\begin{array}{l}0.23 \\
(0.02)^{* * *}\end{array}$ & $\begin{array}{l}2616 \\
(342)^{* * *}\end{array}$ & $\begin{array}{l}0.12 \\
(0.02)^{* * *}\end{array}$ & $\begin{array}{l}5896 \\
(133) * * *\end{array}$ & $\begin{array}{l}0.26 \\
(0.01)^{* * *}\end{array}$ \\
\hline 0.99 & $\begin{array}{l}8975 \\
(2231)^{* * *}\end{array}$ & $\begin{array}{l}0.04 \\
(0.10) \\
\end{array}$ & $\begin{array}{l}2637 \\
(2690)\end{array}$ & $\begin{array}{l}-0.08 \\
(0.08) \\
\end{array}$ & $\begin{array}{l}-43 \\
(2536) \\
\end{array}$ & $\begin{array}{l}-0.21 \\
(0.11) *\end{array}$ & $\begin{array}{l}12907 \\
(947)^{* * *}\end{array}$ & $\begin{array}{l}0.24 \\
(0.12)^{* * *} \\
\end{array}$ & $\begin{array}{l}4550 \\
(799) * * *\end{array}$ & $\begin{array}{l}0.09 \\
(0.02)^{* * *}\end{array}$ & $\begin{array}{l}12045 \\
(265)^{* * *}\end{array}$ & $\begin{array}{l}0.22 \\
(0.01)^{* * *}\end{array}$ \\
\hline $\begin{array}{l}\text { Average } \\
\text { treatment effect }\end{array}$ & $\begin{array}{l}1343 \\
(735)^{*} \\
{[-214,2902]}\end{array}$ & & $\begin{array}{l}333 \\
(500) \\
{[-727,1392]}\end{array}$ & & $\begin{array}{l}2981 \\
(925)^{* * *} \\
{[1020,4941]}\end{array}$ & & & & & & & \\
\hline $\begin{array}{l}\text { Gini Coefficient of } \\
\text { affected districts }\end{array}$ & 0.37 & & 0.36 & & 0.34 & & & & & & & \\
\hline
\end{tabular}

Notes: Robust standard errors in the bracket. ${ }^{* *}, * *, *$, stand for significance at $1 \%, 5 \%$ and $10 \%$ respectively. There are 84393 observations. Household covariates include sex, age, years of education, ethnicity of the household head, and household size. The consumption (outcome variable of interest) is composed of food and non-food expenses and exclude the household investment on durable assets (land, houses, machinery etc.) 
Table 4-4 Estimates using Change-in-Change method

\begin{tabular}{|c|c|c|c|c|c|c|c|c|c|c|c|c|}
\hline \multirow[b]{2}{*}{ Quantile } & \multicolumn{2}{|l|}{ Income } & \multicolumn{2}{|c|}{ Income \% } & \multicolumn{2}{|c|}{ Consumption } & \multicolumn{2}{|c|}{ Consumption \% } & \multicolumn{2}{|c|}{$\begin{array}{l}\text { Consump. } \\
\text { Including CPI by } \\
\text { component }\end{array}$} & \multicolumn{2}{|c|}{$\begin{array}{l}\text { Consump. \% } \\
\text { Including CPI by } \\
\text { component }\end{array}$} \\
\hline & Coeff. & SE & Coeff. & SE & Coeff. & SE & Coeff. & SE & Coeff. & SE & & SE \\
\hline 1 & $1596^{* * *}$ & 100 & $3.8^{* * *}$ & .11 & $-461^{* * *}$ & 89 & $-.07^{* * *}$ & .02 & 632 & 371 & $0.66^{* *}$ & 0.30 \\
\hline 2 & $4434^{* * *}$ & 65 & $4.0^{* * *}$ & .04 & $-842^{* * *}$ & 99 & $-.11^{* * *}$ & .01 & 640 & 457 & 0.38 & 0.27 \\
\hline 3 & $6671^{* * *}$ & 63 & $3.9^{* * *}$ & .04 & $-1246^{* * *}$ & 126 & $-.13^{* * *}$ & .01 & 962 & 567 & 0.27 & 0.20 \\
\hline 4 & $8491^{* * *}$ & 241 & $3.4^{* * *}$ & .19 & $-1690^{* * *}$ & 146 & $-.14^{* * *}$ & .01 & 1392 & 837 & 0.28 & 0.17 \\
\hline 5 & $7951^{* * *}$ & 271 & $1.1^{* * *}$ & .07 & $-1976^{* * *}$ & 207 & $-.13^{* * *}$ & .01 & $1941^{*}$ & 1025 & 0.27 & 0.17 \\
\hline 6 & $8213^{* * *}$ & 267 & $0.8^{* * *}$ & .03 & $-2372^{* * *}$ & 240 & $-.13^{* * *}$ & .01 & $2749 * *$ & 1350 & 0.25 & 0.16 \\
\hline 7 & $8978^{* * *}$ & 334 & $0.6^{* *}$ & .03 & $-2787^{* * *}$ & 292 & $-.12^{* * *}$ & .02 & $3724^{* *}$ & 1700 & 0.23 & 0.15 \\
\hline 8 & $10620^{* * *}$ & 437 & $0.5^{* *}$ & .02 & $-2816^{* * *}$ & 372 & $-.09^{* * *}$ & .02 & $4888^{* * *}$ & 1949 & $0.22^{*}$ & 0.12 \\
\hline 9 & $13450^{* * *}$ & 647 & $0.5^{*}$ & .03 & $-2681^{* * *}$ & 764 & -.04 & .03 & $7748^{* * *}$ & 2088 & $0.28^{* * *}$ & 0.09 \\
\hline
\end{tabular}

Table 4-5 Robustness check (Placebo test)

\begin{tabular}{l|llllllllll}
\hline Quantile & $\mathbf{0 . 1}$ & $\mathbf{0 . 2}$ & $\mathbf{0 . 3}$ & $\mathbf{0 . 4}$ & $\mathbf{0 . 5}$ & $\mathbf{0 . 6}$ & $\mathbf{0 . 7}$ & $\mathbf{0 . 8}$ & $\mathbf{0 . 9}$ & $\mathbf{0 . 9 9}$ \\
\hline Income & -1156 & -378 & 190 & 24 & 76 & 358 & 525 & 342 & -257 & 7800 \\
& $(2043)$ & $(486)$ & $(446)$ & $(405)$ & $(445)$ & $(338)$ & $(466)$ & $(934)$ & $(1758)$ & $(11014)$ \\
& & & & & & & & & & \\
\hline Consumption & -28 & -165 & -280 & -278 & -237 & -410 & -436 & -308 & -691 & -1715 \\
& $(280)$ & $(248)$ & $(333)$ & $(399)$ & $(418)$ & $(438)$ & $(505)$ & $(589)$ & $(725)$ & $(2832)$ \\
& & & & & & & & & & \\
\hline
\end{tabular}

Figure 4-1 Income (absolute) recovery

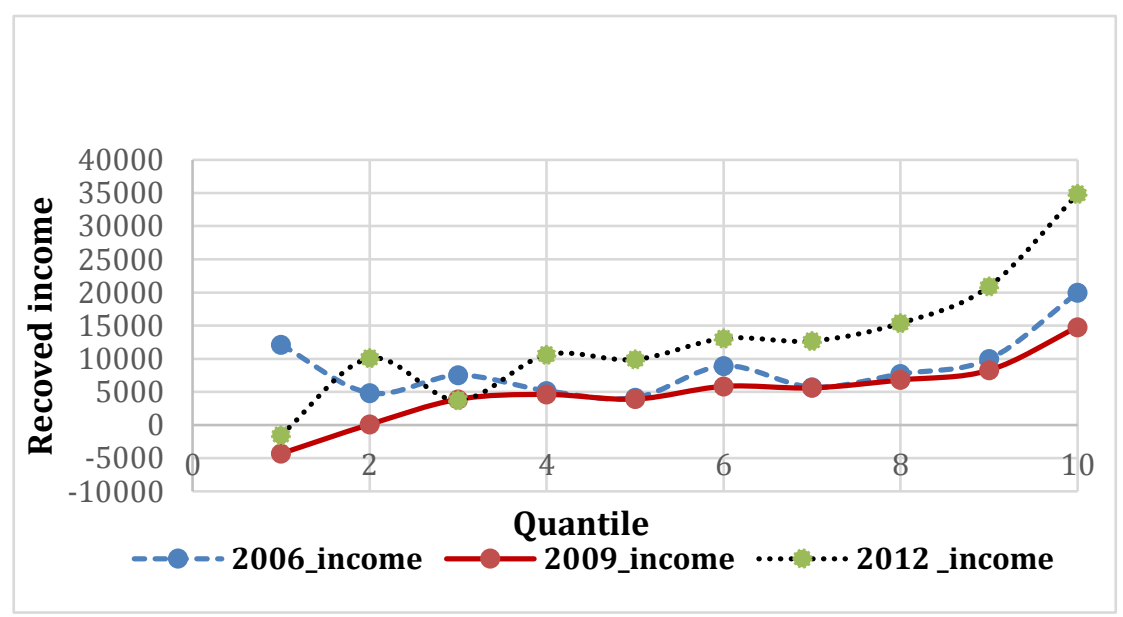


Figure 4-2 Income recovery as a Percentage of average income

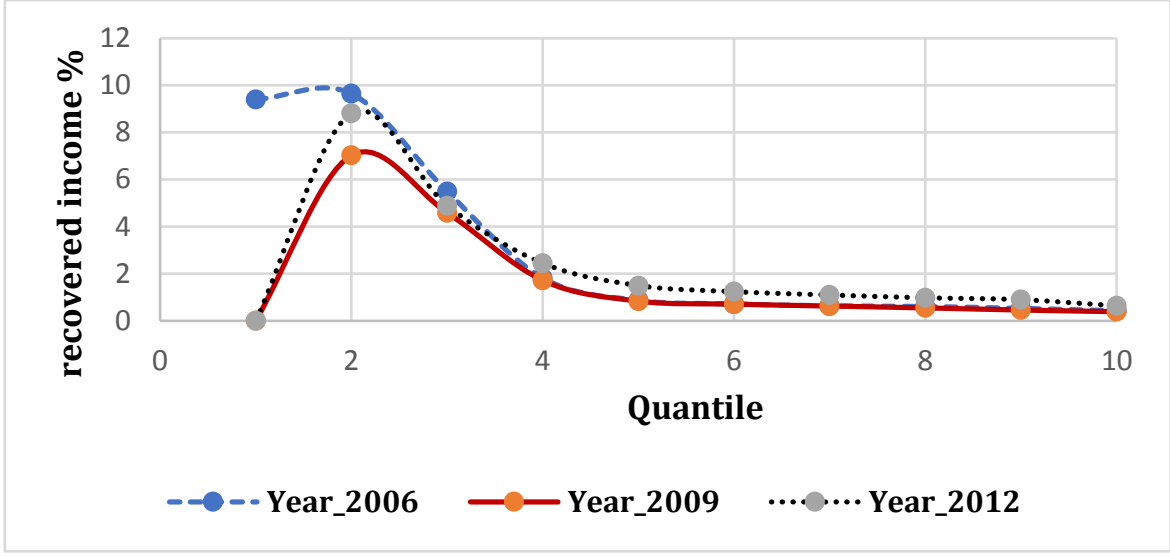

Figure 4-3 Income recovery (absolute) in CIC method

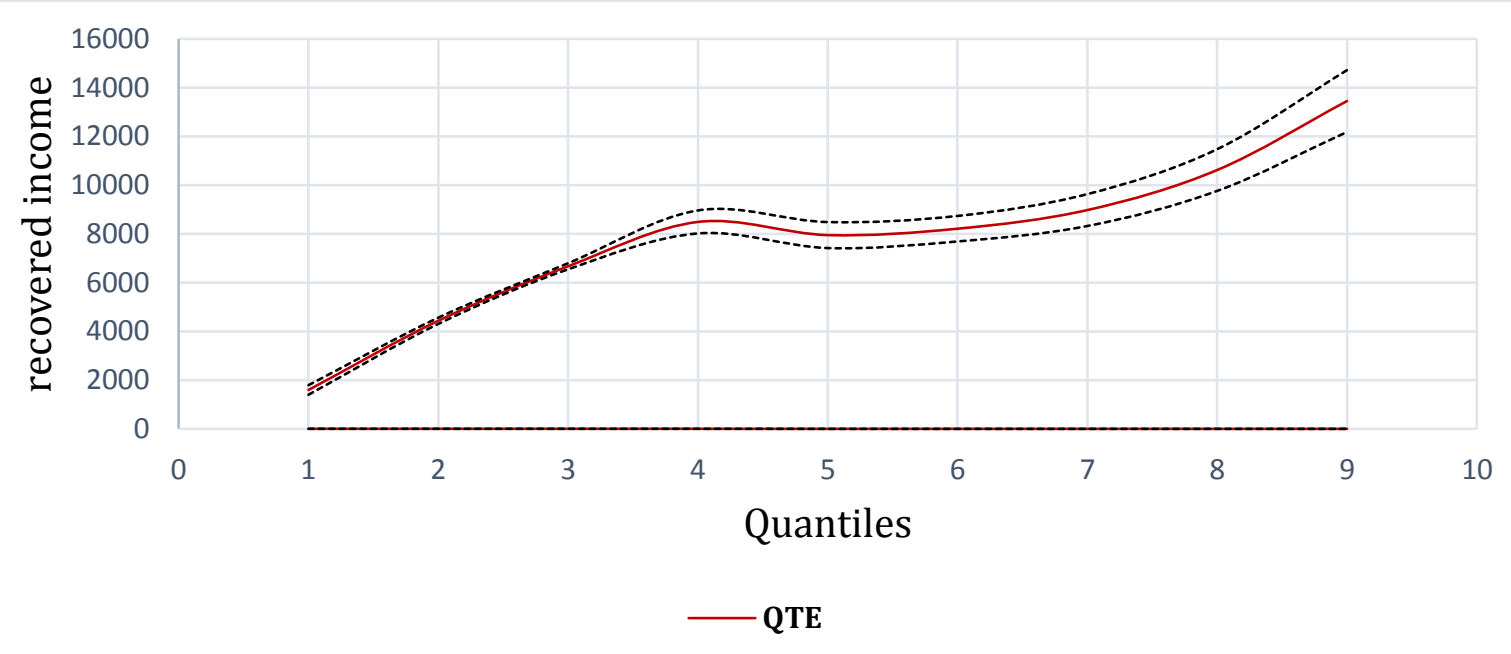

Figure 4-4 Income recovery as a percentage of average income in CIC method

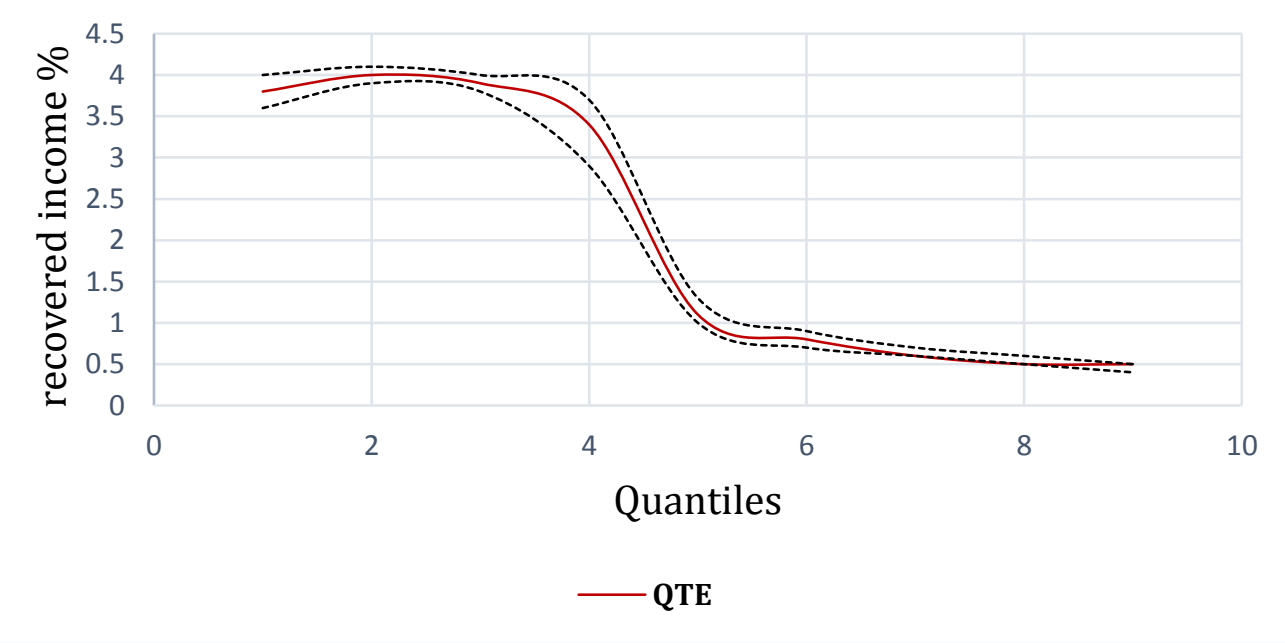


Figure 4-5 Observed Consumption recovery

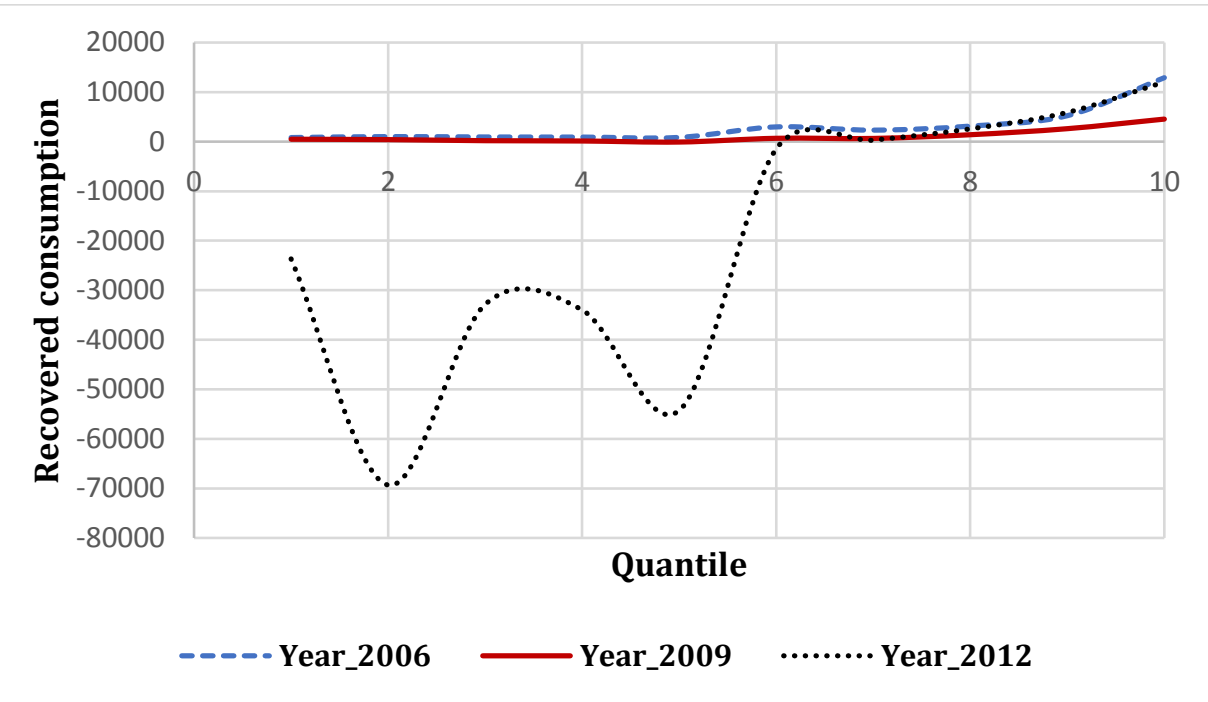

Figure 4-6 Consumption recovery as a percentage of average consumption

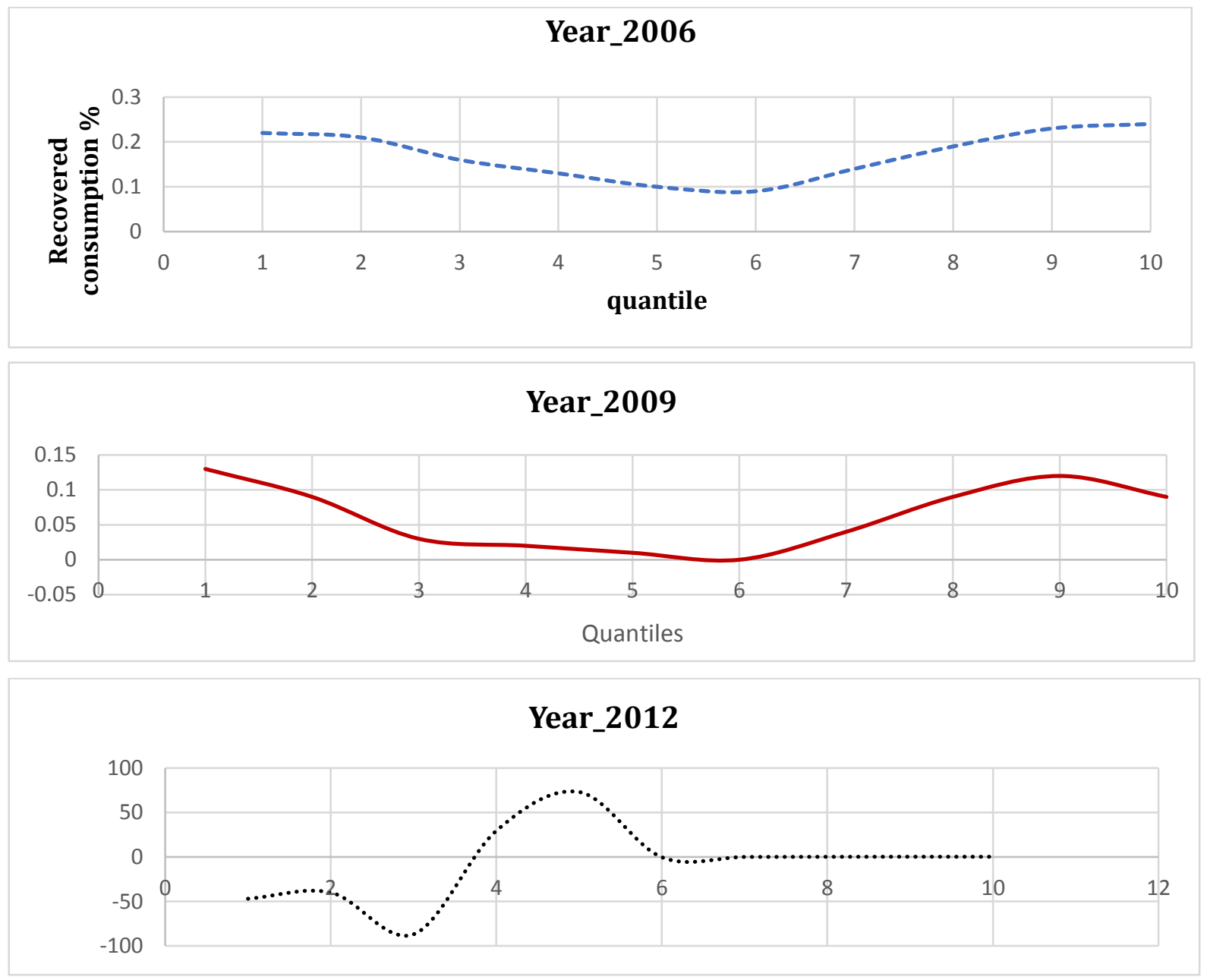


Figure 4-7 Consumption recovery in CIC method (absolute)

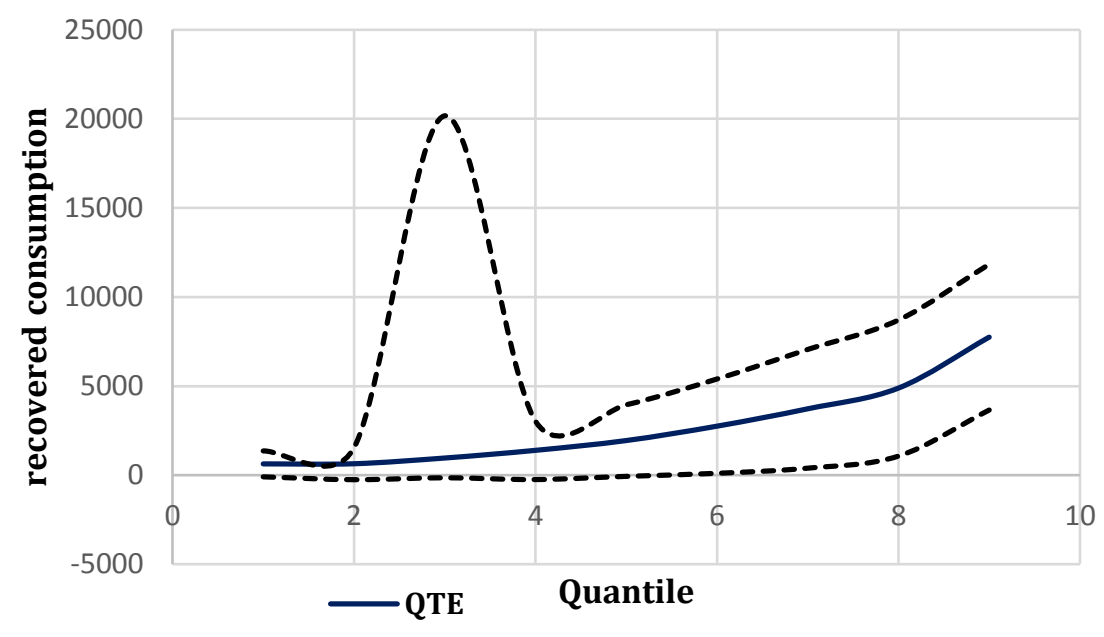

Figure 4-8 Consumption recovery as a percentage of average consumption in CIC method

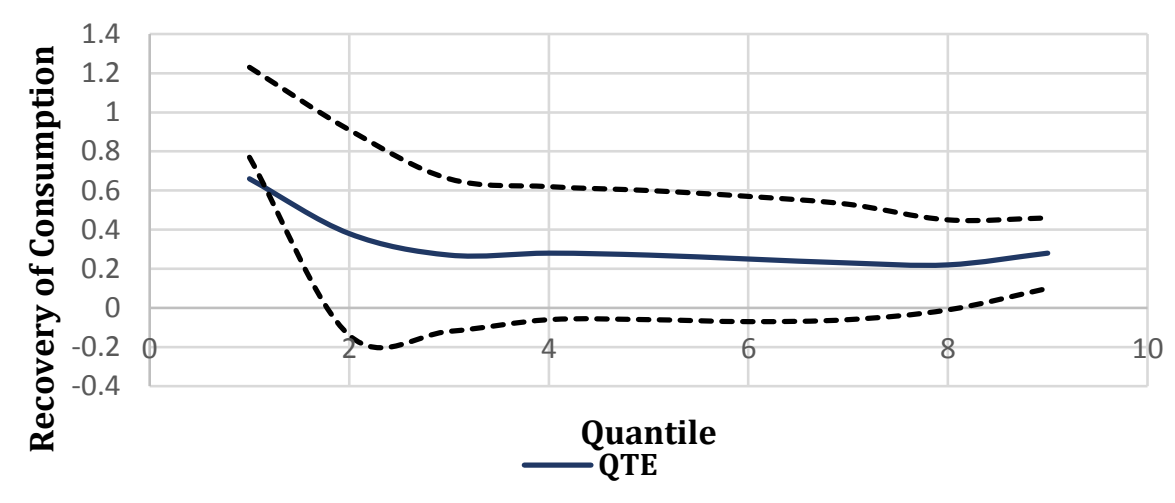

Figure 4-9 Inequality indices in all districts

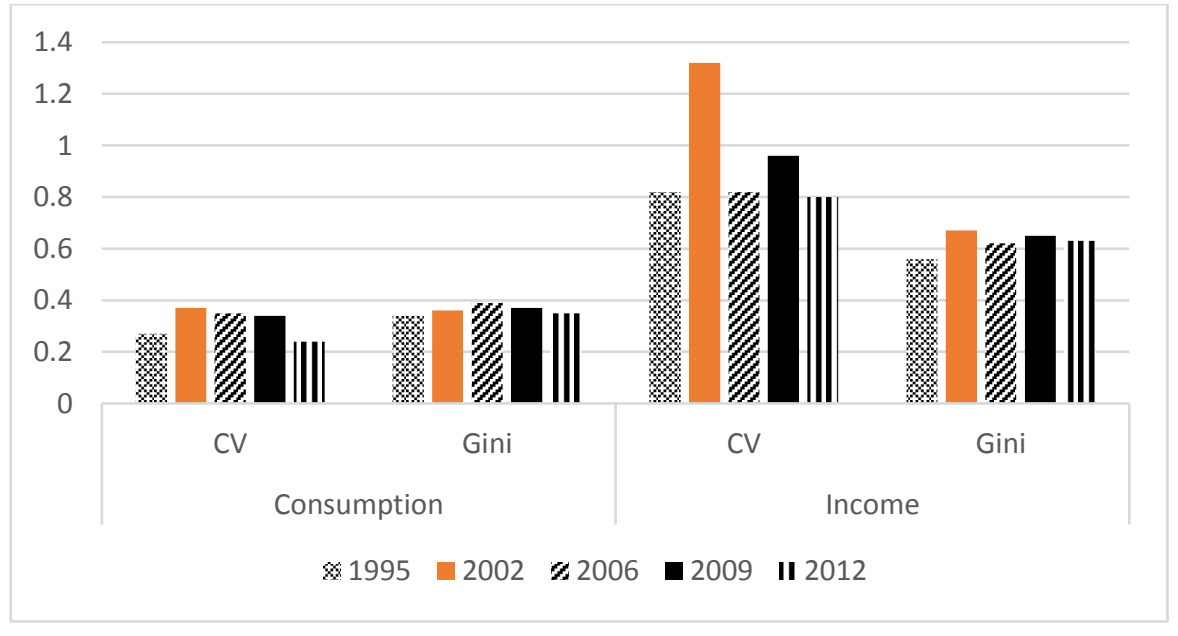


Figure 4-10 Inequality indices in affected and not affected districts
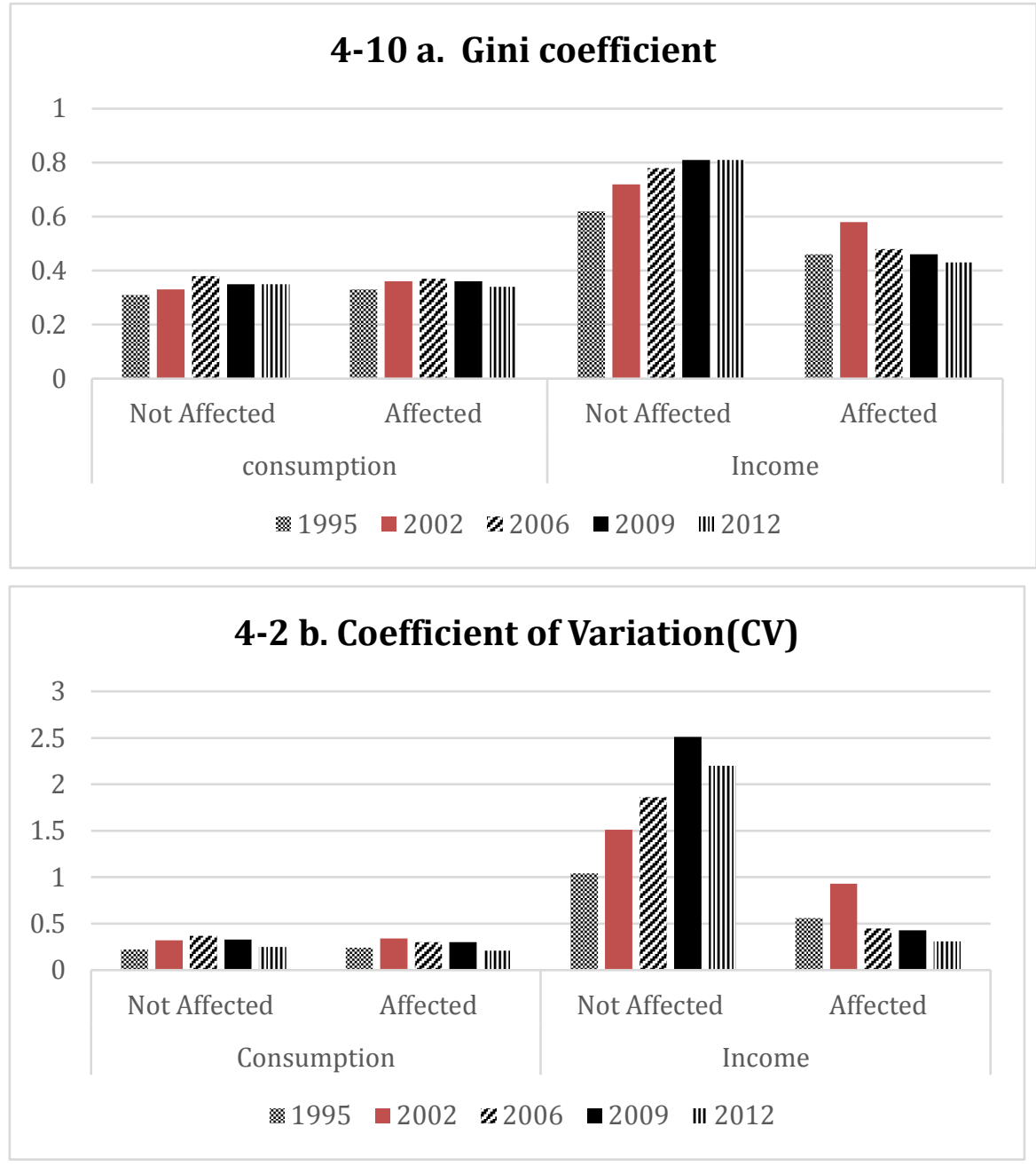

\section{Figure 4-11}

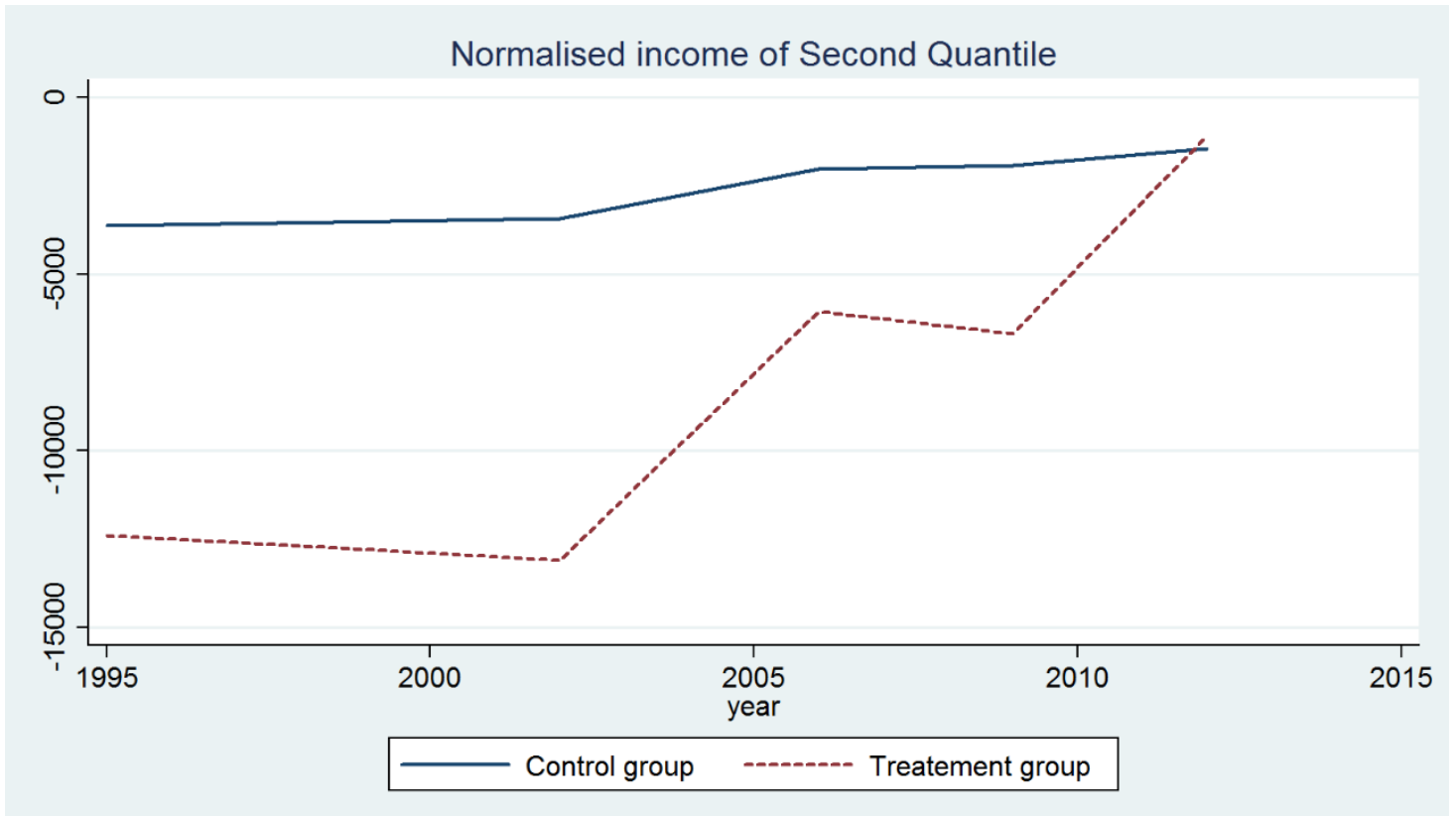


Figure 4-12

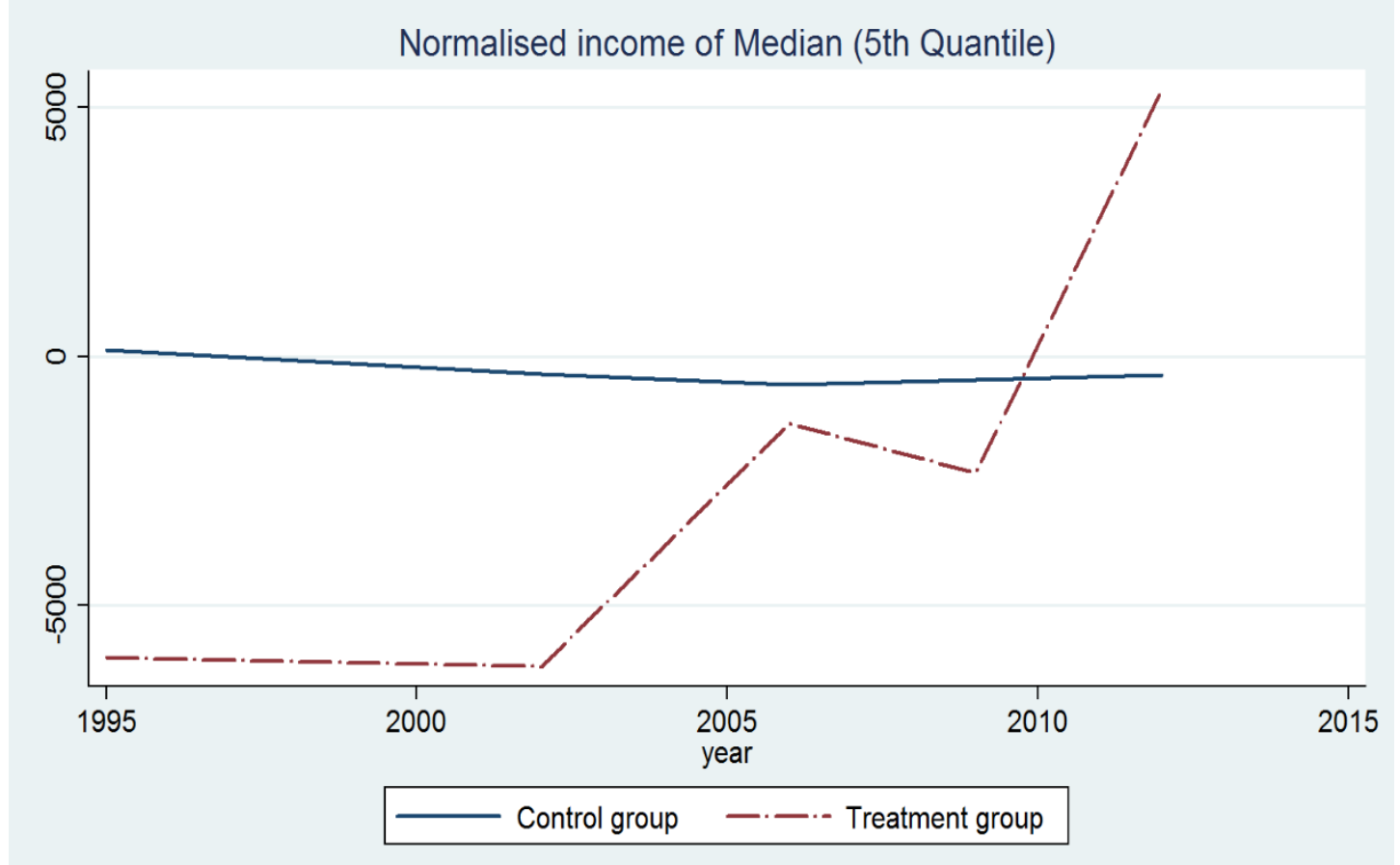

Figure 4-13

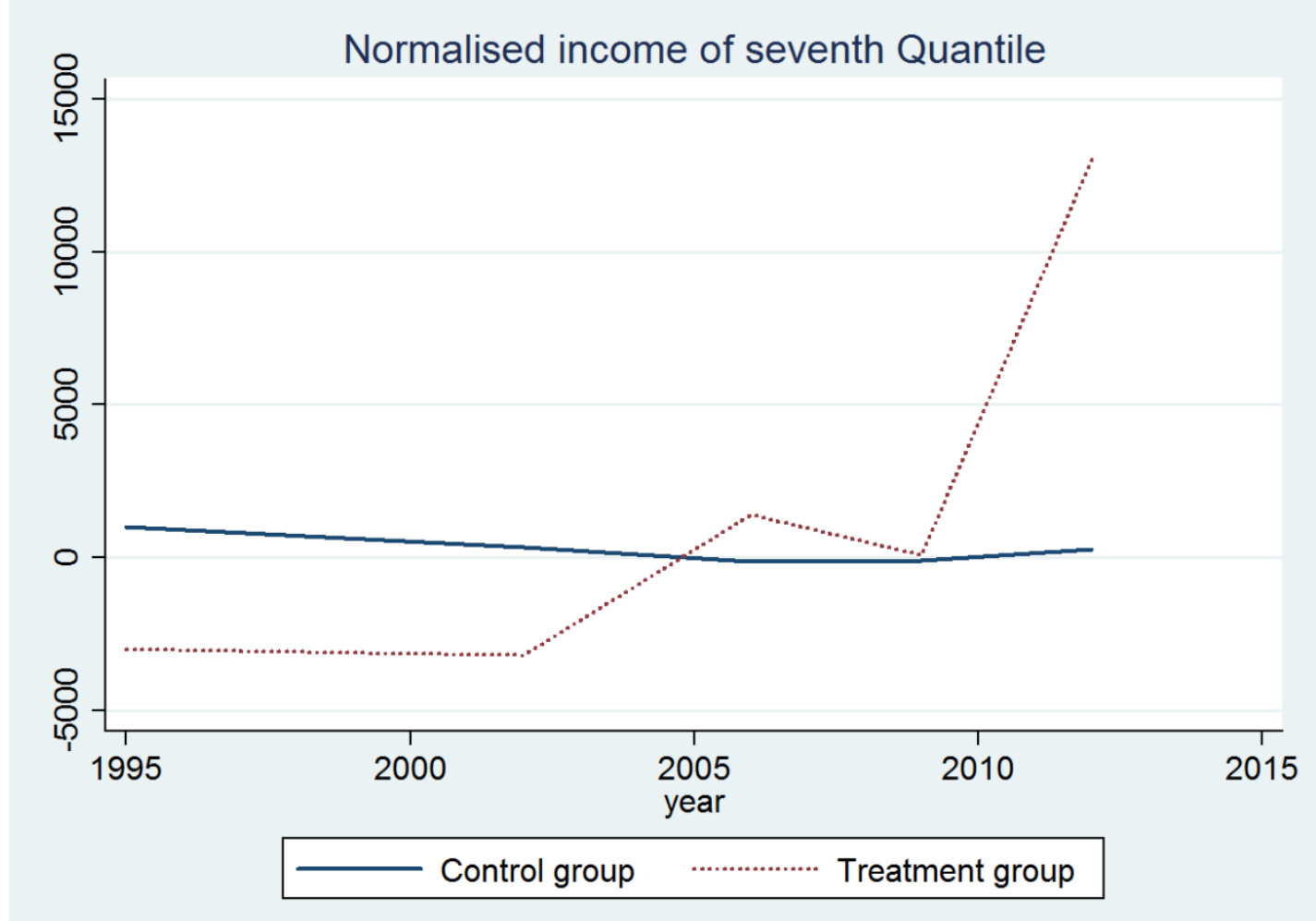


Figure 4-14

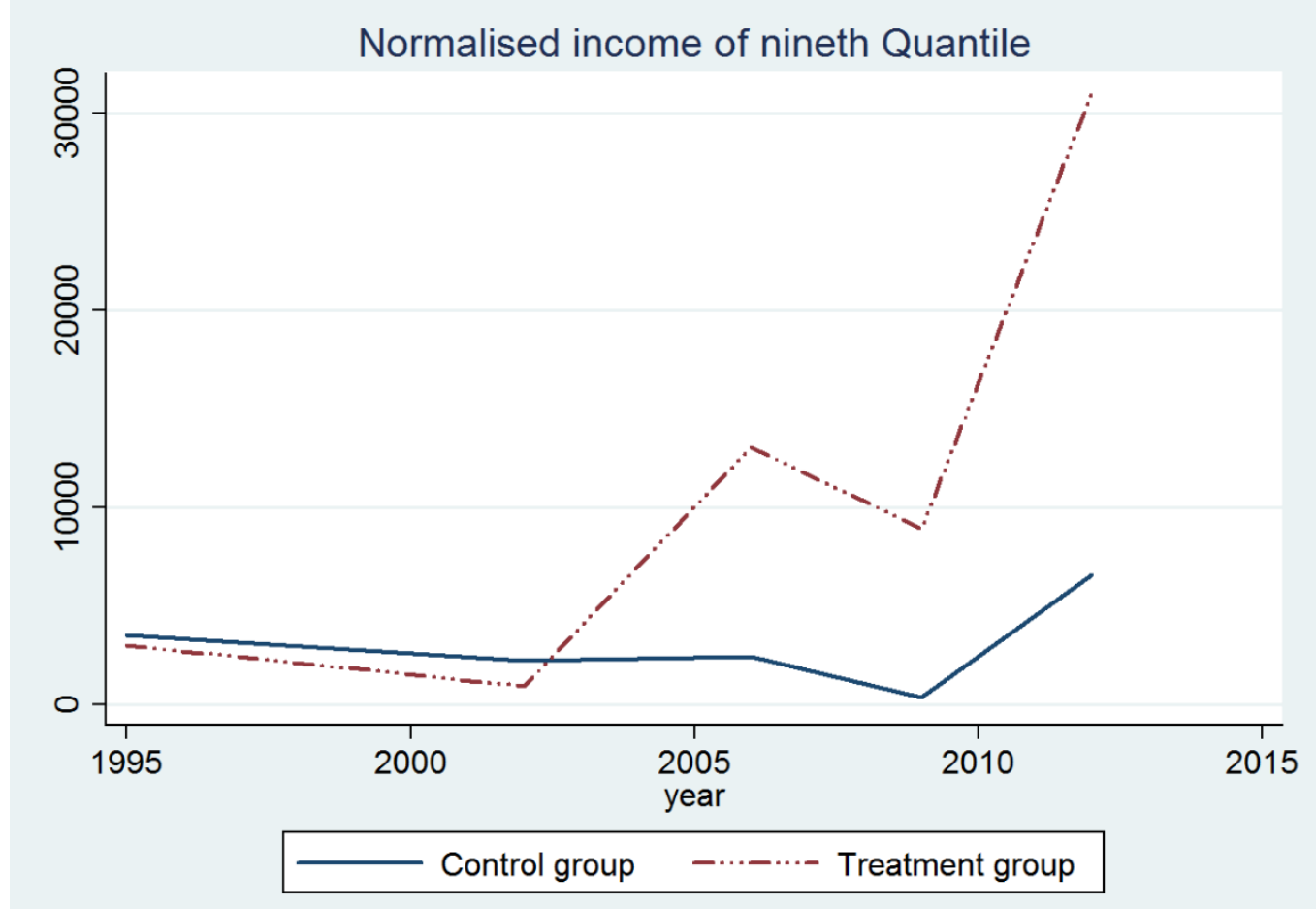

Figure 4-15

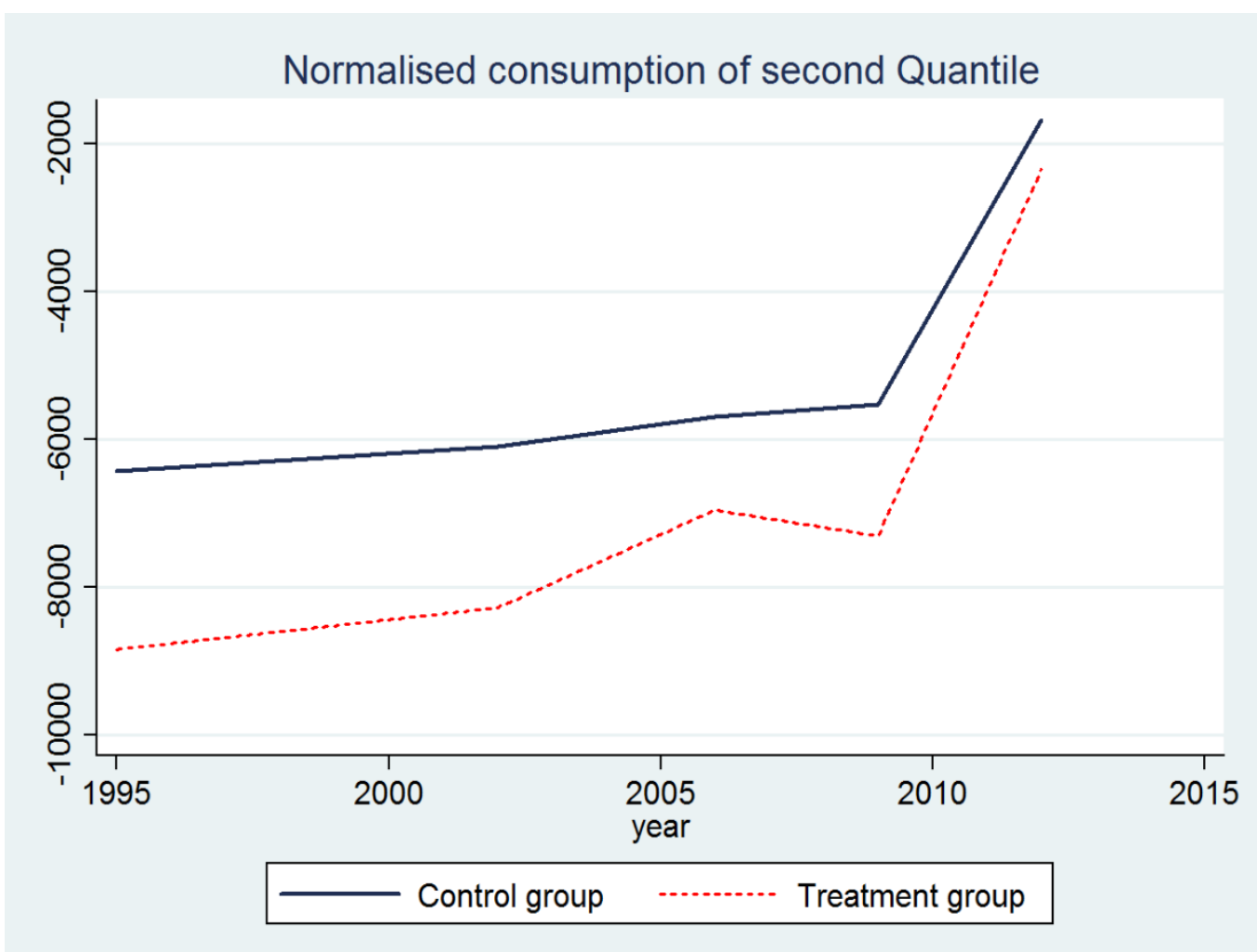


Figure 4-16

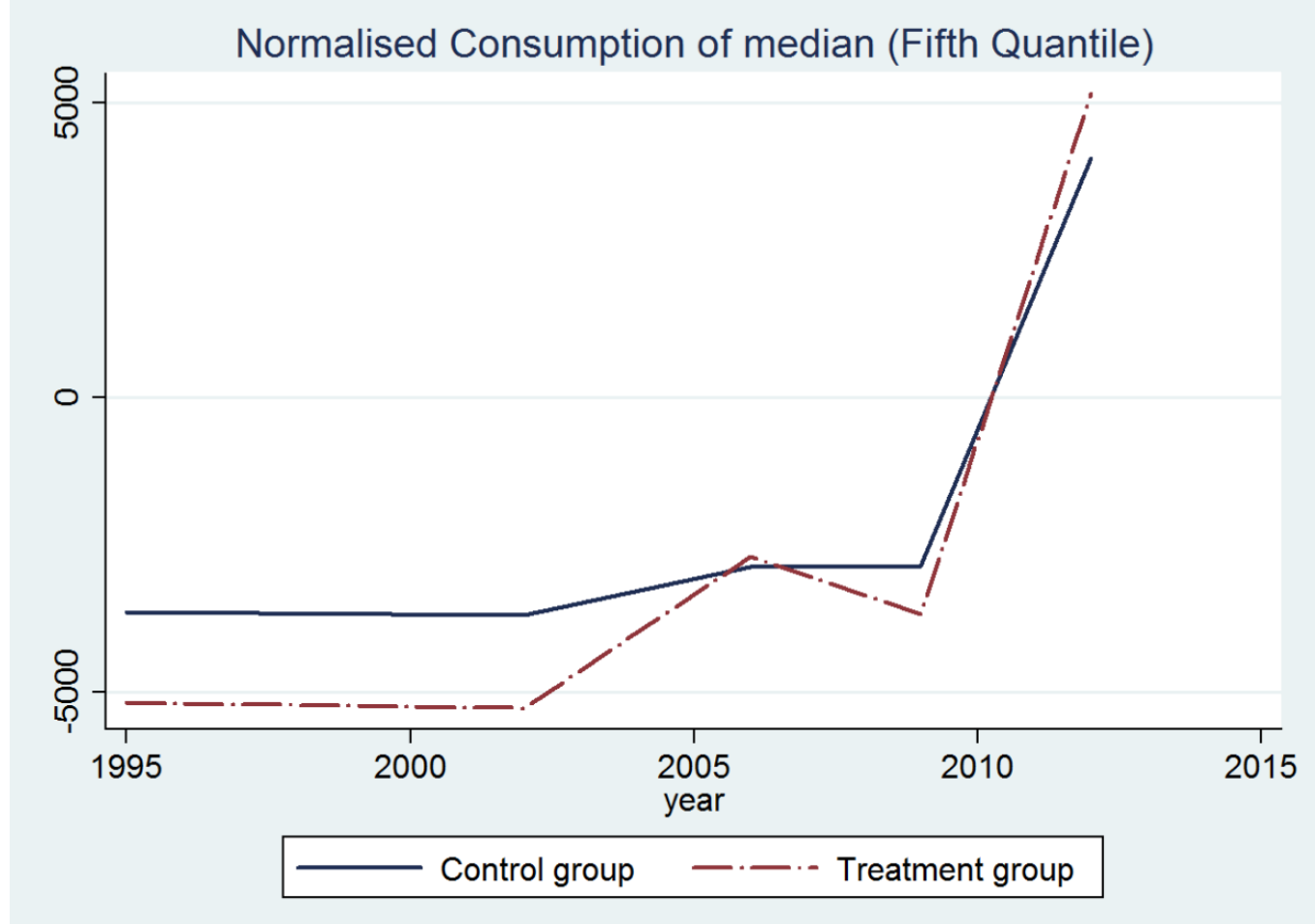

Figure 4-17

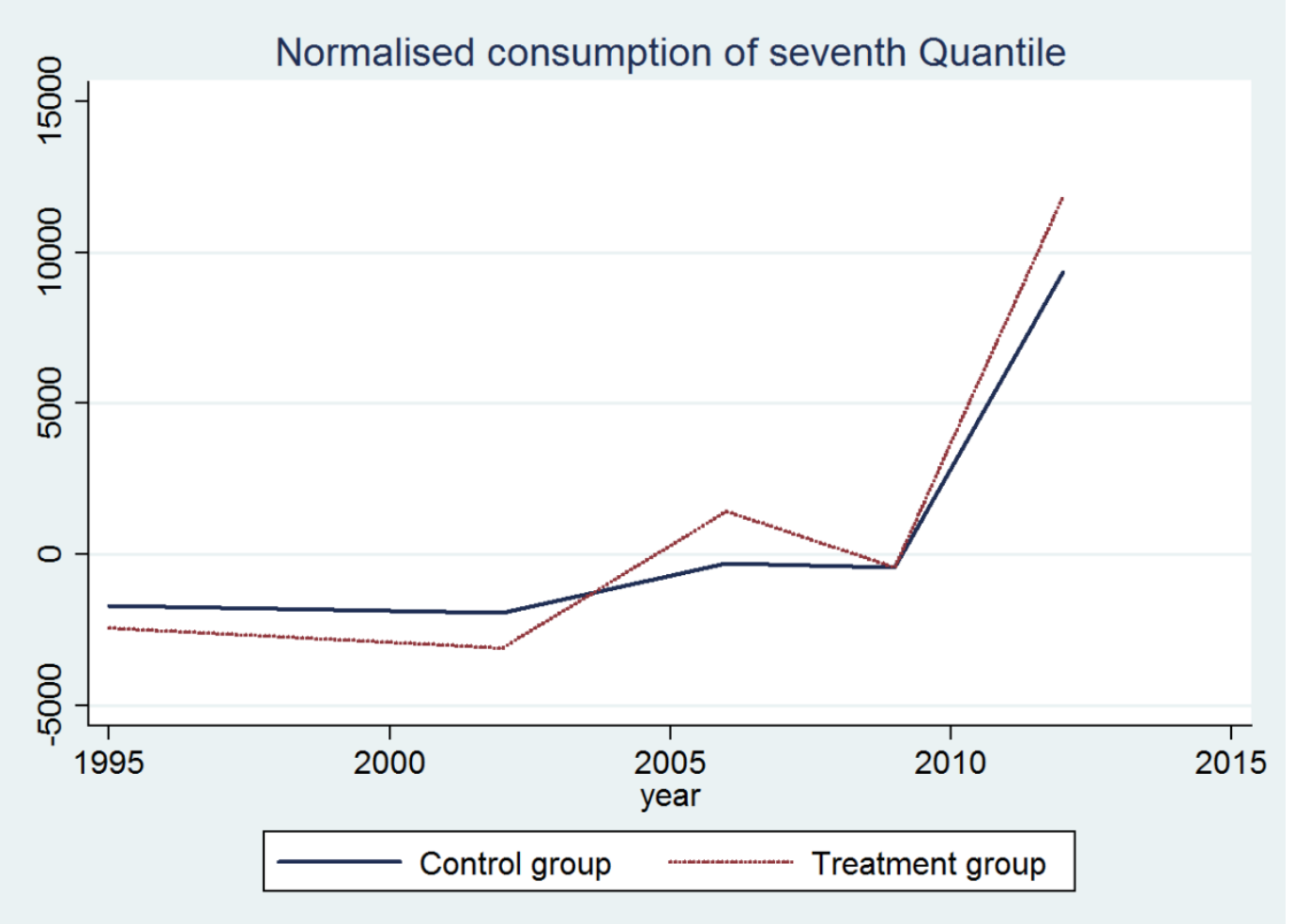


Figure 4-18

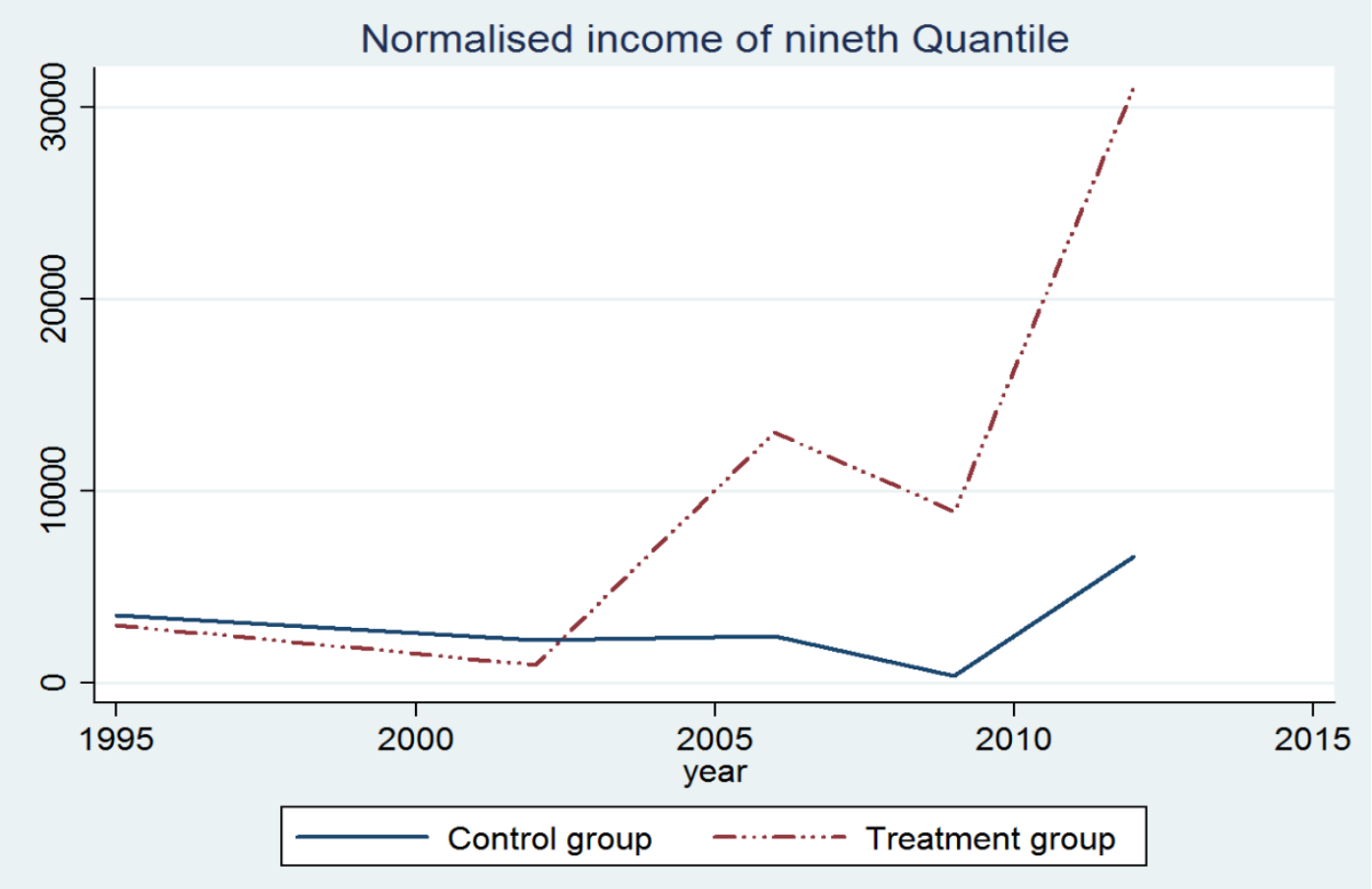




\subsection{References}

Albala-Bertrand, J. M. (1993). Natural disaster situations and growth: A macroeconomic model for sudden disaster impacts. World Development, 21(9), 1417-1434.

Aldrich, D.P. (2010). Separate and unequal: Post-tsunami aid distribution in southern India. Social Science Quarterly, 91(5), 1369-1389.

Alesch, D. J., Holly, J. N., Mittler, E. \& Nagy. R. (2001). Organizations at risk: What happens when small businesses and not-for-profits encounter natural disasters? Fairfax, VA: Public Entity Risk Institute.

Arnall, A., Thomas, D. S. G., Twyman, C., \& Liverman, D. (2013). Flooding, resettlement, and change in livelihoods: evidence from rural Mozambique. Disasters, 37 (3), 468-488.

Athey, S. \& Imbens, G. W. (2006). Identification and inference in nonlinear difference in difference. Econometrica, 74(2), 431-497.

Attanasio, 0. \& Székely, M. (1999). An asset-based approach to the analysis of poverty in Latin America (IDB Working Paper No. 109).

Barrett, C.B., Marenya, P.P., McPeak, J., Minten, B., Murithi, F., Oluoch-Kosura, W., Place, F., Randrianarisoa, J.C., Rasambainarivo, J., \& Wangila, J. (2006). Welfare dynamics in rural Kenya and Madagascar. Journal of Development Studies, 42(2), 248-277.

Becchetti, L. \& Castriota, S. (2011). Does microfinance work as a recovery tool after disasters? Evidence from the 2004 tsunami. World Development, 39(6), 898-912.

Boano, C. (2009). Housing anxiety and multiple geographies in post-tsunami Sri Lanka. Disasters, 33 (4), 762-78.

Buia, A. T., Dungeyb, M., Nguyenc, C. V. \& Phamb, T. P. (2014). The impact of natural disasters on household income, expenditure, poverty, and inequality: evidence from Vietnam. Applied Economics, 46 (15), 1751-1766.

Campano, F, \& and Salvatore, D. (2006). Income distribution. Oxford: Oxford University Press.

Carter, M. R. \& Barrett, C. B. (2006). The economics of poverty traps and persistent Smoothing and Asset Protection (NBER Working Paper No. 19702).

Cavallo, A., Cavallo, E. \& Rigobon, R. (2014). Prices and supply disruptions during disasters. Review of Income and Wealth, 60 (2), 449-471.

Chang, S.E. \& Falit-Baiamonte, A. (2002). Disaster vulnerability of businesses in the 2001 Nisqually Earthquake. Environmental Hazards, 4(2/3), 59-71. 
Chernozhukov V \& Hansen, C. (2006). Instrumental quantile regression inference for structural and treatment effect models. Journal of Econometrics, 132(2), 491-525.

Cuaresma, J.C., Hlouskova, J., \& Michael Obersteiner, M. (2008). Natural disasters as creative destruction? Evidence from developing countries. Economic Inquiry, 46(2), 214-226.

De Alwis, D. \& Noy, I. (2016). Sri Lankan households a decade after the Indian Ocean tsunami (CESifo Working Paper Series No. 6136).

Department of Census and Statistics (2016). Sri Lanka poverty indicators: Household income and expenditure survey - 2016.

Department of Census and Statistics (2005). Report on impact of tsunami 2004 on Sri Lanka. Retrieved from_http://www.statistics.gov.lk/tsunami/census/Summarynew.pdf

Dalhamer, J. M. \& Tierney, K. J. (1998). Rebounding from disruptive events: Business recovery following the Northridge Earthquake. Sociological Spectrum, 18, 121-141.

Dong, Y., \& Shen, S. (2018). Testing for rank invariance or similarity in program evaluation. The review of Economics and Statistics, 100(1), 78-85.

Food and Agriculture of the United Nations (2015). The impact of natural hazards and disasters on agriculture, food security and nutrition: A call for action to build resilient livelihood. Italy: Author.

Fussell, E. (2015). The long-term recovery of New Orleans' Population after Hurricane Katrina. American Behavioural Scientist, 59(10), 1231-1245.

Government of Sri Lanka. (2005). Post tsunami recovery and reconstruction strategy, May 2005.

Government of Sri Lanka. (2006). Post tsunami recovery and reconstruction. Joint report of the Government of Sri Lanka and development partners, December 2006.

Hallegatte S., Bangalore, M., Bonzanigo, L., Fay, M., Narloch, U., Rozenbuerg, J., \& VogtSchilb, A, (2014). Climate change and poverty: An analytical framework (Policy research working paper 7126). Washington, DC: World Bank.

Hallegatte, S. \& Dumas, P. (2009). Can natural disasters have positive consequences? : investigating the role of embodied technical change. Ecological economics, 68, 777-786.

Haraguchi, M. \& Lall, U. (2015). Flood risks and impacts: A case study of Thailand's floods in 2011 and research questions for supply chain decision making. International Journal of Disaster Risk Reduction, 14, 256-272.

Hallegatte, S. \& Vogt-Schilb, A. (2016). Are losses from natural disasters more than just asset losses? : The role of capital aggregation, sector interactions, and investment behaviors. World Bank policy research working paper no. 7885 . 
International Monitory Fund. (2017). IMF data mapper. Retrieved from http://www.imf.org/external/datamapper/PPPPC@WEO/OEMDC/ADVEC/WEOWOR LD/LKA

Jaramillo, C. (2009). Do natural disasters have Long-term effects on growth? (Universidad de los Andes Department of Economics Research Paper Series).

Jayasuriya, S. \& McCawley, P. (2010). The Asian tsunami: Aid and reconstruction after tsunami. Cheltenham, UK: Edward Elgar Publishing.

Kammerbauera, M. \& Wamslerb, C. (2017). Social inequality and marginalization in postdisaster recovery: Challenging the consensus?. International Journal of Disaster Risk Reduction, 24, 411-418.

Karim, A. \& Noy, I. (2016). Poverty and natural disasters-A qualitative survey of the empirical literature. The Singapore Economic Review, 61(1).

Kazianga, H. \& Udry. C. (2006). Consumption smoothing? Livestock, insurance and drought in rural Burkina Faso. Journal of Development Economics, 79(2), 413-46.

Kellenberg, D. K., \& Mobarak, A. M. (2008). Does rising income increase or decrease damage risk from natural disasters. Journal of Urban economics, 63, 788-802.

Khasalamwa, S. (2009). Is build back better response to vulnerability? Analysis of the post tsunami humanitarian interventions in Sri Lanka. Norwegian Journal of Geography, 63 (1), $73-88$.

Kim, C. K. (2010). The effect of natural disasters on long run economic growth. Ann Arbor: University of Michigan.

Koenker, R., \& G. Bassett. (1978). Regression quantiles. Econometrica, 46, 33-50.

Lam, N.S.N., Pace, K. R., Campanella, J., LeSage, \& Arenas, H. (2009). Business return in New Orleans: Decision making amid post-Katrina uncertainty. PLoS ONE, 4(8).

Landry, C. E., Bin, O., Hindsley, P., Whitehead, J., \& Wilson, K. (2007). Going home: evacuation-migration decisions of Hurricane Katrina survivors. Southern Economic Journal, 74(2), 326-343.

Madden, J. F. (2000). Changes in income inequality within U.S. metropolitan areas. Kalamazoo. MI: W.E. Upjohn Institute for Employment.

Melly, B. \& Santangelo, G. (2015). The changes-in-changes model with covariates (Working Paper).

Ministry of Environment. (2009). Sri Lanka strategy for sustainable development. Sri Lanka: Author.

Muñoz C. E. \& Tate E. (2016). Unequal recovery? Federal resource distribution after a Midwest flood disaster. Int. J Environ Res Public Health, 13(5). 
Okuyama, Y., \& Sahin, S. (2007). Impact estimation of disasters: A global aggregate for 1960 to 2007 (Policy research working Paper 4963).

Parente, P.M.D.C. \& Santos-Silva, J.M.C. (2016). Quantile regression with clustered data. Journal of Econometric Methods, forthcoming.

Parker, M. (2018). “How global is 'global inflation'?”, Journal of Macroeconomics, forthcoming.

Pawel, D. (2017). Quantile treatment effects in the presence of covariates (RAND Labor and Population Working Paper).

Rodríguez-orregea, E., de la Fuente, A., de la Torre, R., Moreno, H., \& Rodriguez, C. (2009). The impact of natural disasters on human development and poverty at the municipal level in Mexico. Journal of Development Studies, 49(3), 442-455.

Shaughnessy, T. M., Mary L. White, M. L., \& Brendler, M. D. (2010). The income distribution effect of natural disasters: An analysis of Hurricane Katrina, The journal of regional analysis and policy, 40(1), 84-95.

Skidmore, M. \& Toya, H. (2002). Do natural disasters promote growth? Economic Inquiry, 40 (4), 664-687.

Swedish International Development Agency. (2009). Long term perspectives on the response to the Indian Ocean tsunami 2004: A joint follow up evaluation of the links between relief, rehabilitation, and development. (Article No. SIDA52010en).

Tierney, K. J. (1997). Business impacts of the Northridge Earthquake. Journal of Contingencies and Crisis Management, 5(2), 87-97.

The World Bank (2016). World development indicators. Retrieved from https://data.worldbank.org/

Webb, G.R., Tierney, K.J. \& Dahlhamer, J.M. (2000). Businesses and disasters: Empirical patterns and unanswered questions. Natural Hazards Review, 1(2): 83-90.

Webb, G.R., Tierney, K.J. \& Dahlhamer, J.M. (2002). Predicting long-term business recovery from disaster: A comparison of the Loma Prieta Earthquake and Hurricane Andrew. Environmental Hazards, 4, 45-58.

Yamamura, E. (2015). The impact of natural disasters on income inequality: Analysis using panel data during the period 1970 to 2004. International Economic Journal, 29(3), 359374. 


\subsection{Appendices}

\section{Appendix table 4-1: Components of household income and consumption}

\begin{tabular}{|c|c|c|c|}
\hline Income components & Description & $\begin{array}{l}19952006 \\
20092012\end{array}$ & 2002 \\
\hline Paid income & $\begin{array}{l}\text { Income from paid employments (wage/salaries, } \\
\text { commissions, bonus, arrears) }\end{array}$ & $\sqrt{ }$ & $\sqrt{ }$ \\
\hline Agricultural Income & $\begin{array}{l}\text { Income from agricultural activities including value of } \\
\text { produce consumed by the household }\end{array}$ & $\sqrt{ }$ & $\sqrt{ }$ \\
\hline Non-agricultural Income & $\begin{array}{l}\text { Income from non-agricultural activities including value of } \\
\text { products consumed by the household }\end{array}$ & $\sqrt{ }$ & $\sqrt{ }$ \\
\hline Remittance & Local and foreign remittance & $\sqrt{ }$ & $\sqrt{ }$ \\
\hline Transfers & $\begin{array}{l}\text { Receipts of government transfer payment, disability and } \\
\text { relief payments }\end{array}$ & $\sqrt{ }$ & $\sqrt{ }$ \\
\hline Dividends & Dividends and interests & $\sqrt{ }$ & $\sqrt{ }$ \\
\hline Rents \& other income & Property rents and other cash receipts & $\sqrt{ }$ & $\sqrt{ }$ \\
\hline Ad hoc income & $\begin{array}{l}\text { Loans taken, sales of assets, withdrawal of savings, income } \\
\text { received from welfare societies, repayment of loans given, } \\
\text { insurance compensations, lottery and other adhoc gains }\end{array}$ & $\sqrt{ }$ & $\mathrm{X}$ \\
\hline Income components & \multicolumn{3}{|l|}{ Description } \\
\hline Food & \multicolumn{3}{|c|}{ Value of consumed food of the household members excluding boarders and servants } \\
\hline Non food & $\begin{array}{l}\text { Household expenditure on housing fuel and light, persona } \\
\text { communication, education, recreation and cultural activ } \\
\text { goods, household services (laundry, grinding etc.), clothing } \\
\text { household goods. } \\
\text { Non consumption expenses: Savings, payment of In } \\
\text { contributions to trade unions, thrift societies and social s } \\
\text { fund), expenses on social activities, donations, loans given. }\end{array}$ & $\begin{array}{l}\text { care, health, } t \\
\text { ies, nondurab } \\
\text { xtiles and foot } \\
\text { Irance, debt, } \\
\text { curity paymen }\end{array}$ & $\begin{array}{l}\text { port and } \\
\text { ousehold } \\
\text {, durable } \\
\text { ome tax, } \\
\text { rovident }\end{array}$ \\
\hline Servants & Expenses on servant's food and non-food consumption. & & \\
\hline
\end{tabular}




\section{Appendix figure 4-1: Distribution of income}

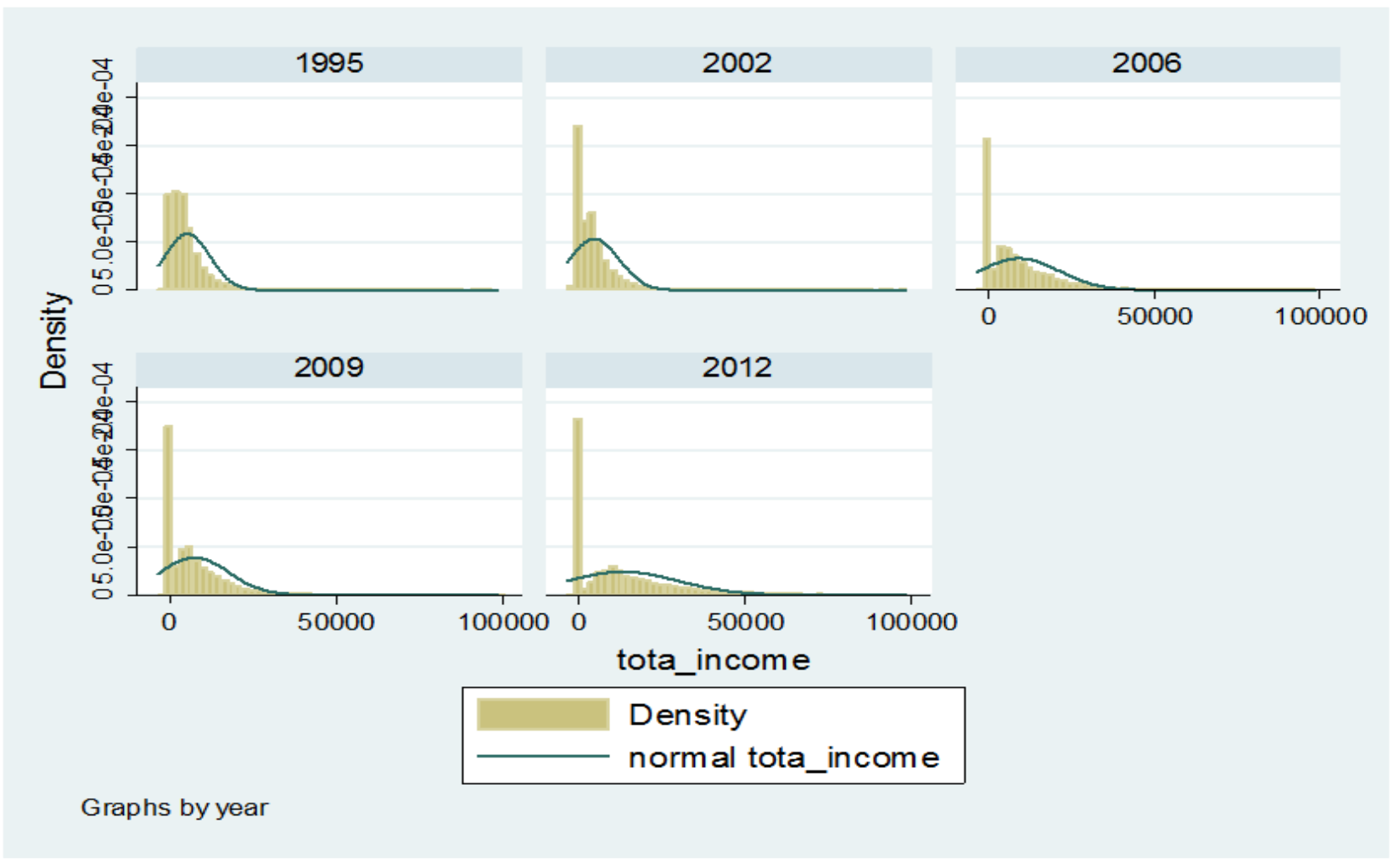

\section{Appendix figure 4-2: Distribution}

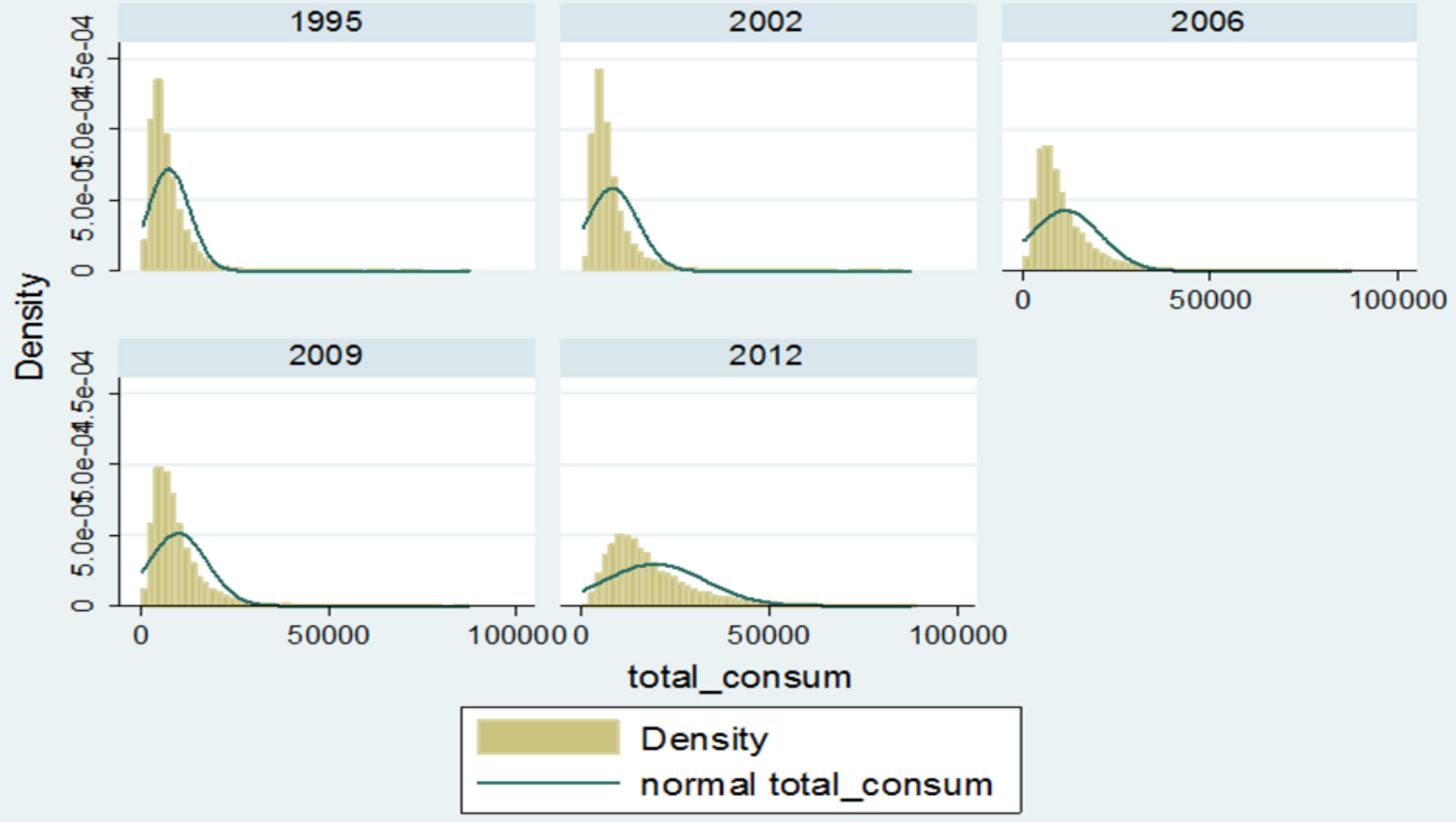

Graphs by year 
Appendix figure 4-3: Income Lorenz curve of Treatment group

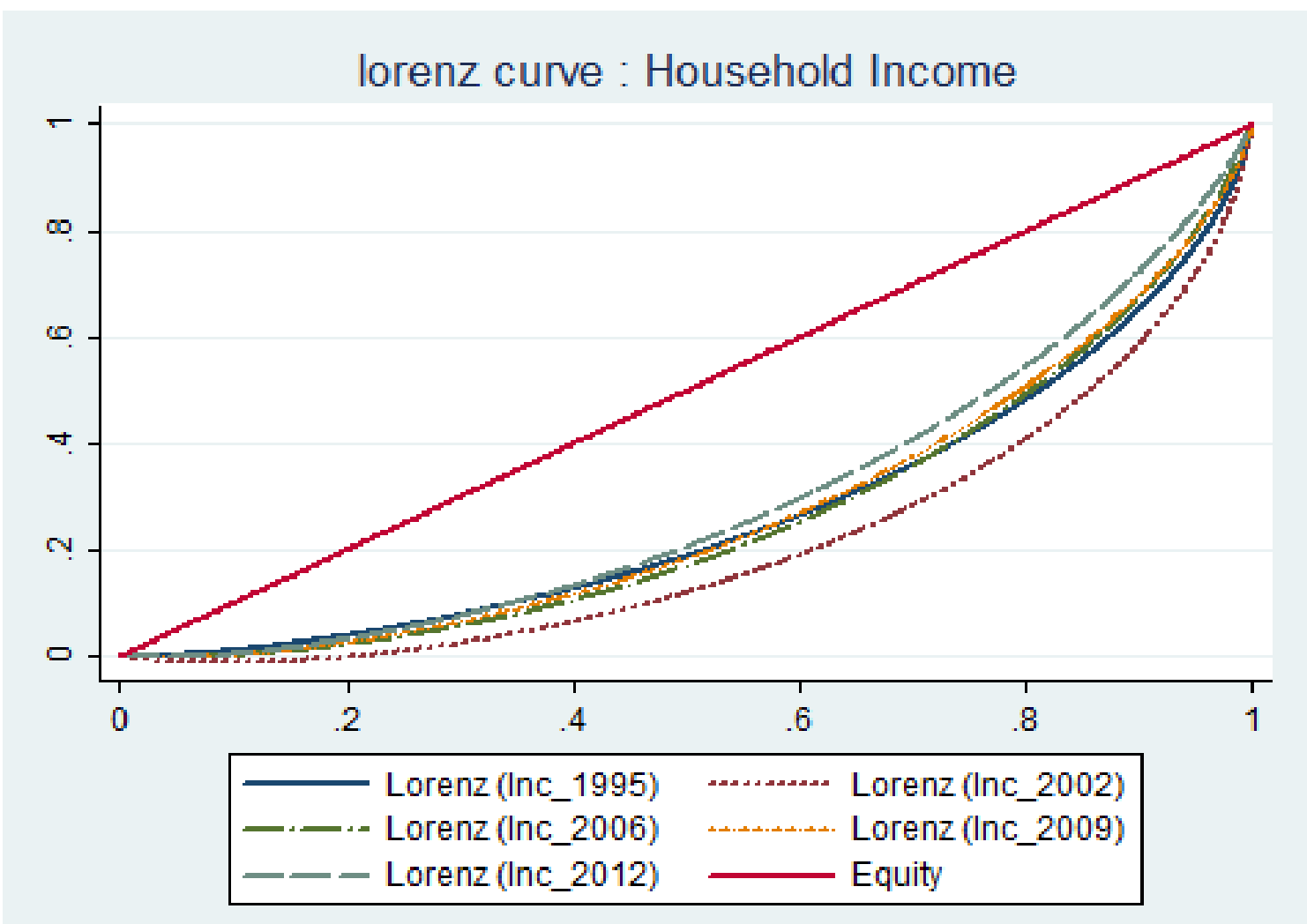

Appendix figure 4-4: Income Lorenz curve of Control group

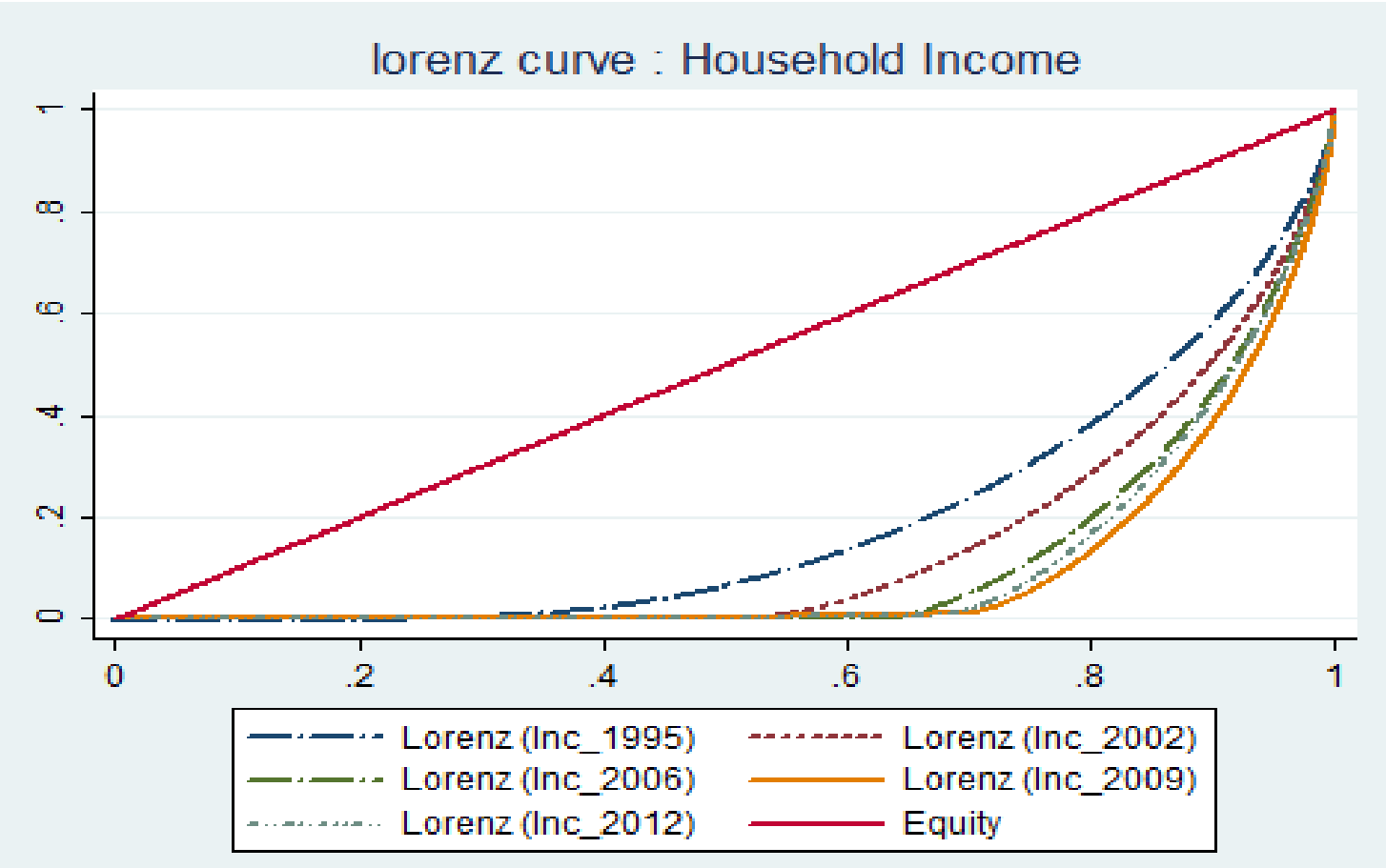


Appendix figure 4-5: Consumption Lorenz curve of Treatment group

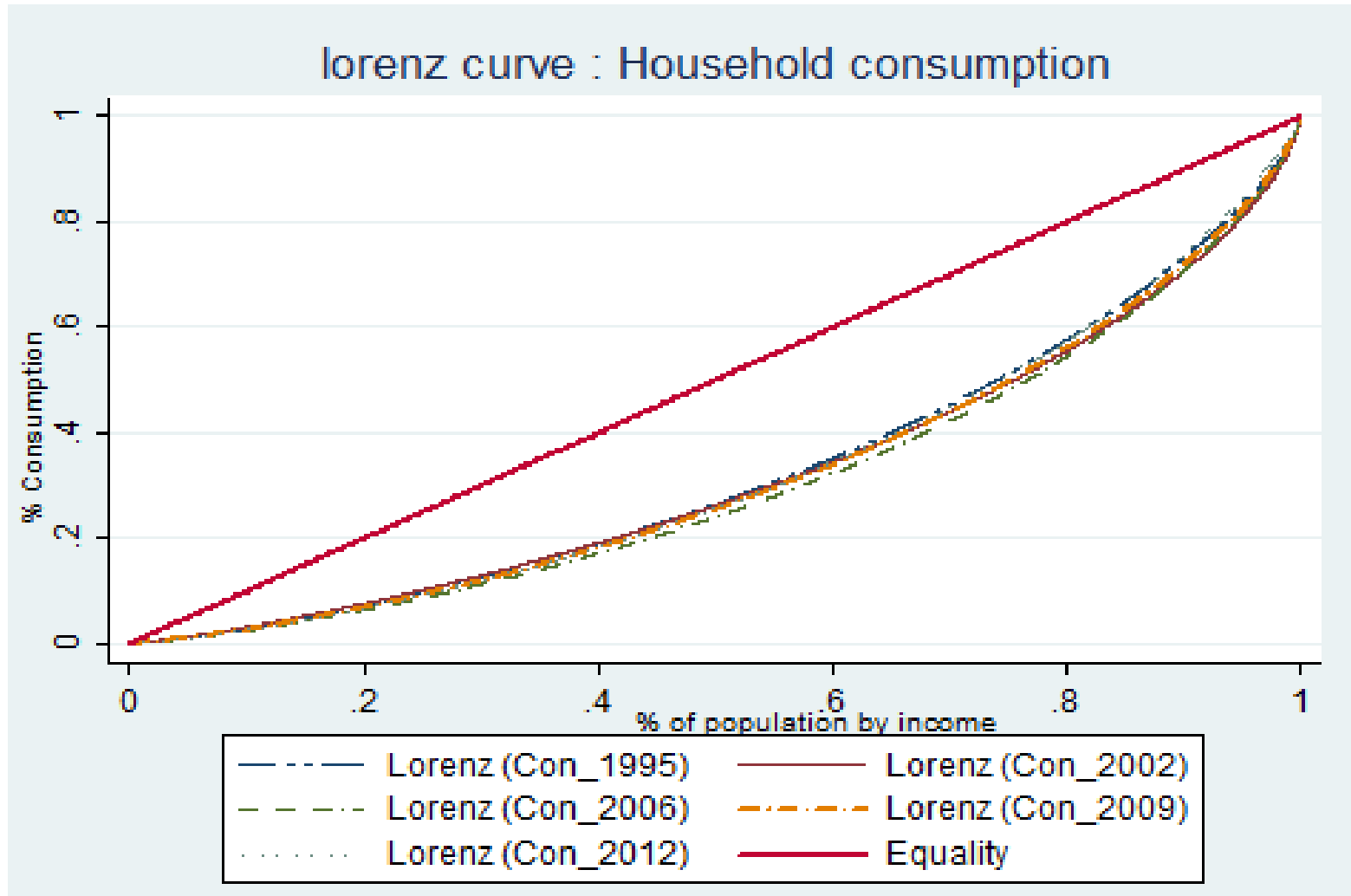

Appendix figure 4-6: Consumption Lorenz curve of Control group

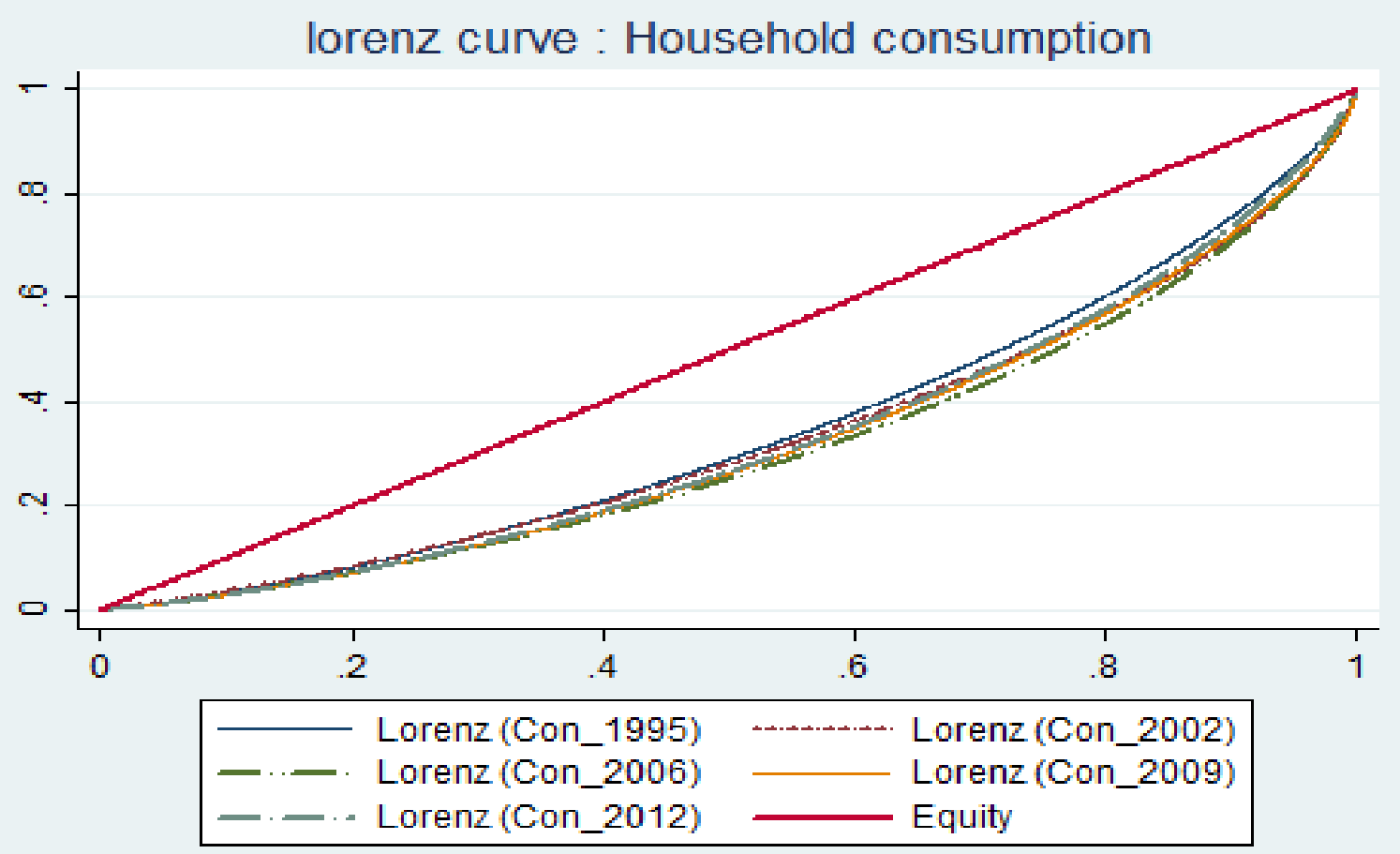


Appendix figure 4-7: Lorenz curve for all districts -Income

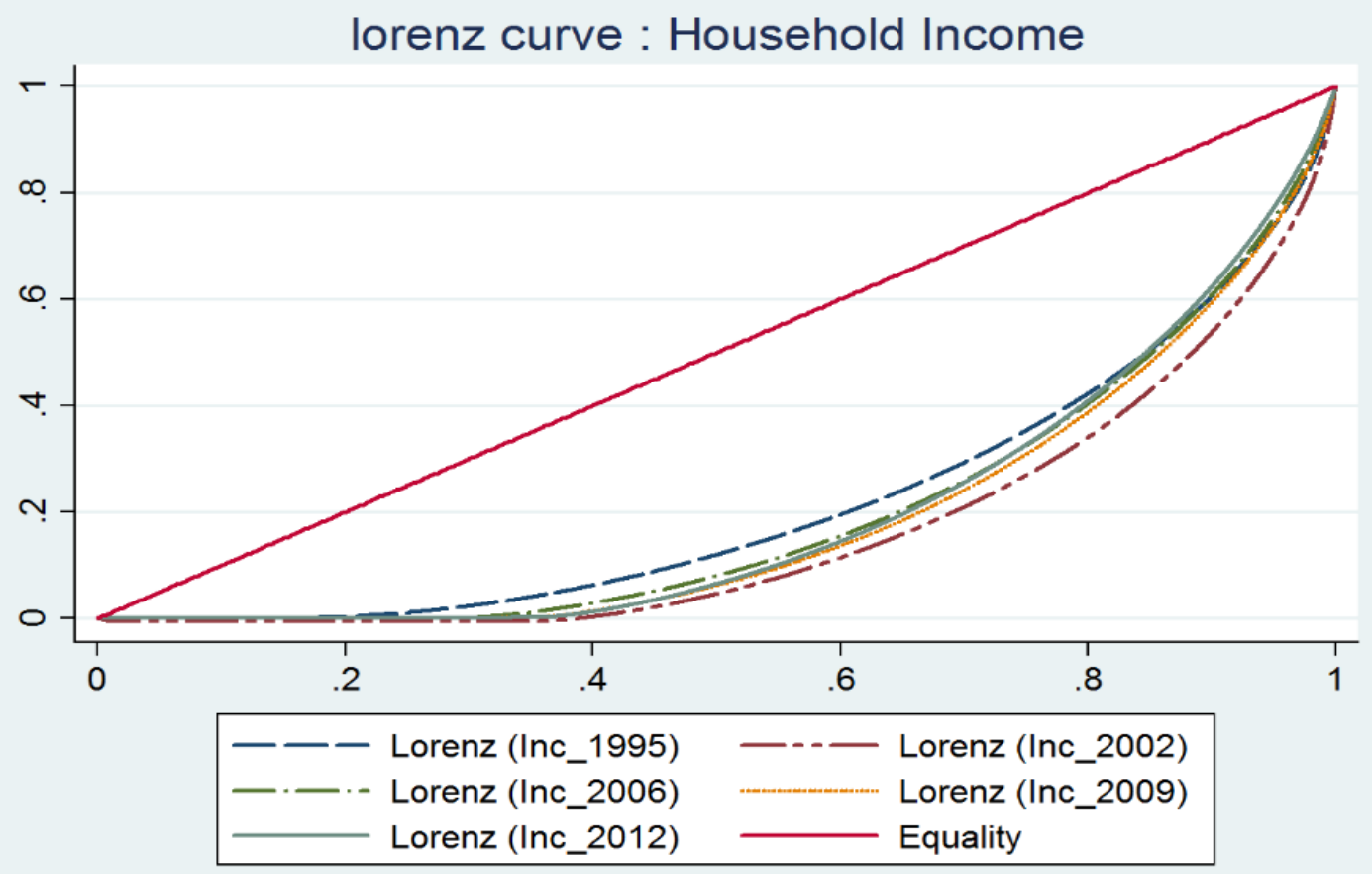

Appendix figure 4-8: Lorenz curve for all districts -Consumption

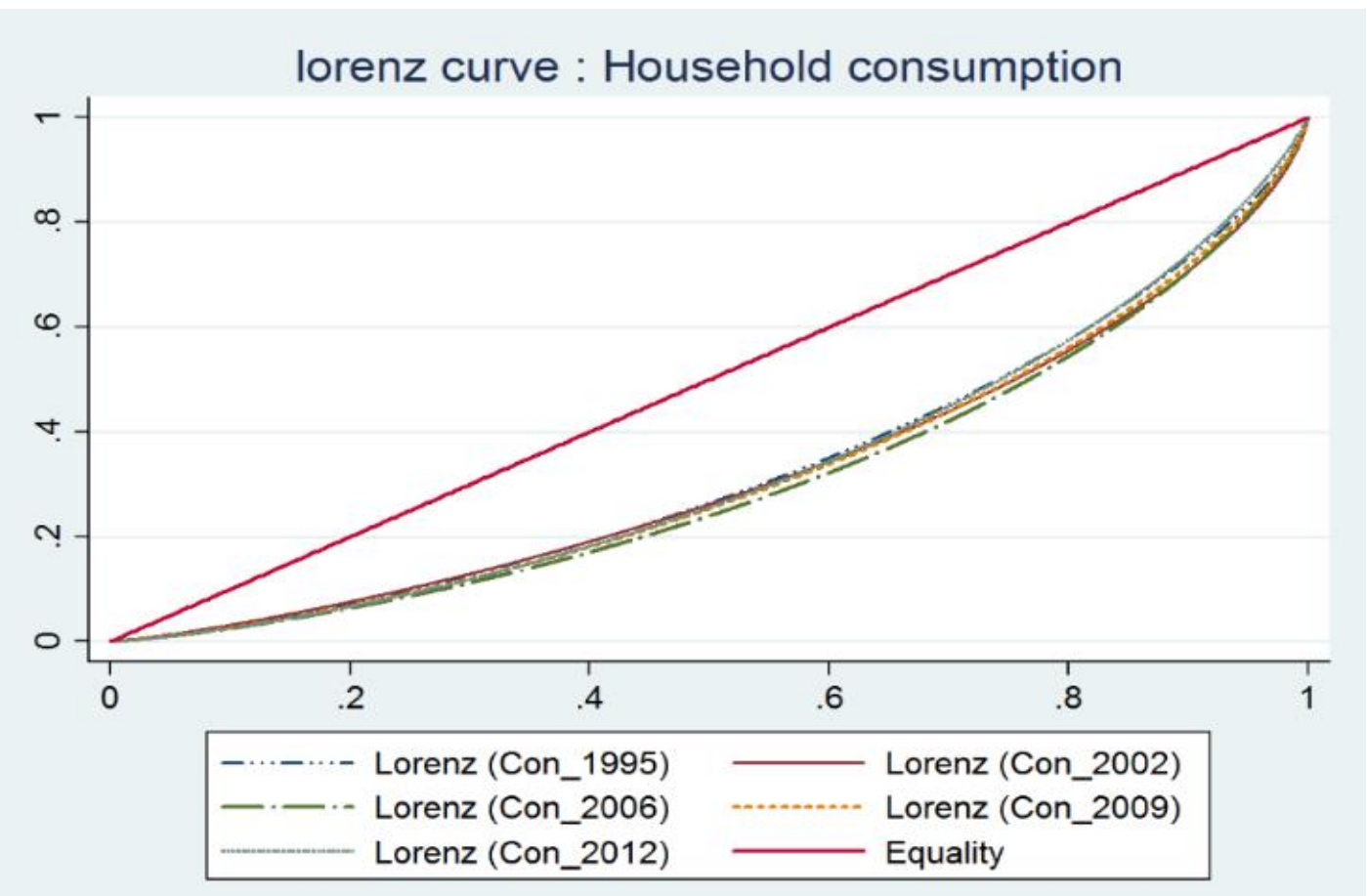




\section{Chapter Five}

\section{Conclusion of the Thesis}

The primary objective of this dissertation was to provide insights about household's wellbeing risks due to natural disasters. The collection of three empirical studies presented in this thesis investigates several dimensions of household risk: exposure to different hazard intensities - such as frequent low-intensity hazards and rare high-intensity disasters, risks in the short and long term, and differing wellbeing measures like health, income, consumption, and income distribution. The following sections present a summary of the empirical findings, their implications, and the limitations.

\subsection{Frequently occurring low intensity disasters}

First, this dissertation reflects the significance of local floods and droughts in generating short-term economic risks to a rapidly growing middle-income country. The first essay presented empirical evidence that frequently occurring local floods and droughts impose a significant risk to individuals' health when they are exposed directly to these hazards, and that this requires outpatient care and even hospitalization for treatment. The second important observation is that the direct impacts on local populations cascade to have ramifications in geographical areas and to populations that are not directly affected by the hazards. These health spill-overs almost always appear to be associated with household sanitation, hygiene conditions and sometimes with land use in the affected environment. 
Finally, both direct and indirect risks associated with flood and drought on health have an economic cost.

The above findings yield several noteworthy considerations for future Disaster Risk Reduction (DRR) interventions. First, we learn that cumulative expected losses from frequent events like floods and droughts are significant, and the economic value of these losses is much higher than monetized directly observed losses. Additionally, some socio-economic and geospatial vulnerability attributes emerge as reliable predictors of these economic losses. Taken together, these findings suggest that in addition to structural DRR measures (hard DRR), alternative policies focusing on the socio-economic environment, and on land use, are crucial to confront disaster risk more fully.

Nonetheless, the estimates obtained in the current study remain an underestimate. The estimated health care costs include only direct expenditures and do not account for healthassociated productivity and income losses, disutility due to experienced pain and inconvenience, and opportunity cost of government health care expenditures that may have higher value to society in other uses. These estimates also does not include any health care cost if incurred after more than one year.

\subsection{Rarely occurring high intensity disasters}

The second study went on to examine the long-term recovery of household income and consumption after the most severe catastrophic natural disaster experienced by Sri Lankans in many decades, the tsunami of 2004. The study has a hopeful message; the area-wide Indian Ocean tsunami shock was strongly associated with increases in household income and consumption persistently up to the eighth year after the disaster. The documented potential for long-lasting recovery suggests that appropriate policies can lead to successful recovery the 'build back better' resolution of the catastrophe.

The third empirical study was designed to determine the variation of the recovery across affected household income groups and to investigate any distributional impacts that may have emerged during the recovery process. It is observed that the recovery varies across income groups disproportionately but that it favored the affected poor households more than the rich. 
Taken all together, the recovery from the 2004 tsunami appears not only long lasting but also enhancing the capacities of the affected households to confront future shocks.

These two empirical studies about the 2004 tsunami have generated a novel understanding of a catastrophic disaster happening in a relatively poor country that is on a rapid growth path. These findings demonstrated the possibility of a successful recovery from a catastrophic disaster that generated growth and benefited households.

However, potentially crucial caveats are worth considering. Methodologically, the treatment identification was limited to area-wide shock concerning part of the affected geographical areas and findings can be generalized only to a part of the all affected areas in the country due to data limitations. In particular, the area affected adversely by the civil conflict, and also by the tsunami, was not included in the assessment provided here because data about it was unavailable.

Additionally, Sri Lanka received a very large quantity of external assistance post-tsunami, much larger than is typical for disaster events (even proportionally to the level of devastation). Whether recovery associated with 'build-back-better' reconstruction was only due to the availability of massive external resources received for rebuilding is still an open question. These limitations mean that study findings need to be interpreted cautiously but can also serve as a starting point for future research, one which I hope to conduct. 